\title{
Memorias do Museu Gœldi
}

\author{
( Museu Paraense)
}

de Historia Natural e Ethnographia

IV.

\section{Os Mosquitos no Pará}

Reunião de quatro trabalhos sobre os Mosquitos indigenas, principalmente as especies que molestam o homem.

PELO PROFESSOR

\section{DR. EMILIO AUGUSTO GOELDI}

DIRECTOR DO MUSEU

Com 144 Figuras no texto e 5 estampas chromolithographicas

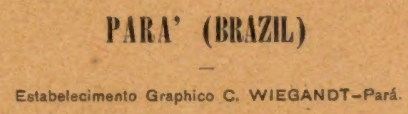

$=$ 



\section{Memorias do Museu Goldi \\ ( Museu Paraense)}

de Historia Natural e Ethnographia

IV.

\section{Os Mosquitos no Pará}

Reunião de quatro trabalhos sobre os Mosquitos indigenas, principalmente as especies que molestam o homem.

PELO PROFESSOR

\section{DR. EMILIO AUGUSTO GOELDI}

\section{DIRECTOR DO MUSEU}

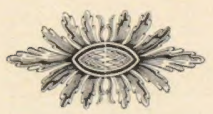

PARA' (BRIZIL) 


\section{Os Mosquitos no Pará}

I. Os mosquitos no Pará encarados como uma calamidade publica.

II. Resumo provisorio dos resultados da campanha de experiencias executadas em 1903, especialmente em relação ás especies Stegomyia fasciata e Culex fatigans, sob o ponto de vista sanitario.

III. Pormenores biologicos principalmente relativos ao cyclo de desenvolvimento das principaes especies indigenas.

JV. Stegomyia fasciata, o mosquito transmissor da febre amarella, e o actual estado de conhecimentos sobre a causa d'esta molestia. (Conferencia realisada perante o Congresso Internacional de Zoologia em Berna (Suissa), agosto 1904.) 



\section{I}

\section{Os Mosquitos no Pará encarados como uma calamidade publica.}

\section{A. - Orientação sobre o conjuncto dos Mosquitos em geral e as especies paraenses em particular.}

\footnotetext{
c In his tam parvis atque tam nullis que - ratio, quanta vis, quam inextricabilis per- fectio! Ubi tot sensus collocavit (natura) in c culice?... qua subtilitate pennas adnexuit?

\& Praelongavit pedum crura, disposuit ieiunam « caveam, uti alvum, avidam sanguinis, et potissimum humani sitim accendit!
}

Plinius, historia naturalis. - LIBER XI.

Conhecem-se actualmente umas 300 especies diversas de Mosquitos em todo o globo. (*)

Repartem-se sobre os diversos continentes do modo seguinte:

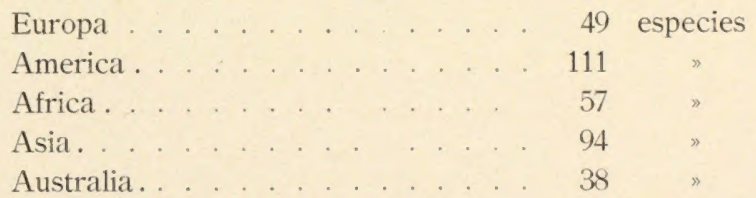

(10 especies ainda cabem ás ilhas oceanicas Bermudas, Fidji, Mauricias, Madeira, sendo que a differença d'este total - 359-do outro acima indicado-300-provém da circumstancia de serem certas especies de Mosquitos encontradas em mais de um continente.)

Vê-se logo que o continente americano não ficou prejudicado no seu quinhão.

Quanto á subdivisão d'este continente, podemos dar a seguinte synopse:

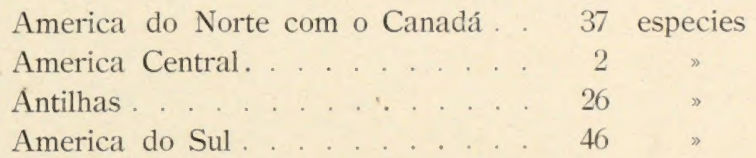

(*) Os dados numericos ahi registrados são em parte extrahidos da novissima grande Monographia sobre os Culicides, de Fred. V. Theobald em Londres $(1901-1902)$ : em parte compilados da recente correspondencia epistolar do mesmo autor commigo e dos especialistas do British Museum em Londres. 
Por ahi vê-se ainda que o total sul-americano importa entre $1 / 3-1 / 2$ do total americano em geral, aproximando-se bem de perto ao total europeu.

Como ao Brazil cabe a maior extensão territorial, cabe-lhe tambem d'aquelle total de 46 especies a parte leonina: são nada menos de 42 as especies de Mosquitos descriptos actualmente como provenientes d'este paiz, ficando apenas 4 especies ainda para toda a parte extra-brazilica.

E' de especial interesse agora sabermos que ao Pará e á Amazonia inferior pertenciam, até o momento em que eu meśmo principiei a occupar-me do assumpto com mais attenção, 18 especies, $-3 / 7$ do total brazileiro. Eu mesmo consegui até agora reunir por aqui 17 especies, 12 das quaes coincidindo com especies anteriormente conhecidas, e 5 especies declaradas novas pelo melhor especialista do assumpto na actualidade.

Os Culicides paraenses, tal qual os conhecemos no actual estado da sciencia zoologica, entram principalmente nos generos Anopheles,-Megarhinus, - Ianthinosoma, Stegomyia, - Culex, - Taeniorhynchus, - Sabethes, sendo reservado um papel secundario aos representantes dos outros generos Psorophora, - Haemagogus, - Wyeomyia, - Limatus.

Vale a pena passar rapidamente em revista os traços mais salientes do habitus especifico de alguns d'estes generos, pois um pouco de orientação geral n'este terreno será proveitosa, ao nosso vêr, não sómente ao medico, mas a qualquer pessoa leiga, que não estiver já por demais enfatuada para comprehender a vantagem que reside no alargamento dos seus proprios conhecimentos, os quaes sobretudo podem provir de alguma familiaridade com as cousas da natureza. Não fallo áquelles que já tudo sabem, e, qual baiacú, tufam de presumpçosa sufficiencia; não é a elles que me dirijo, pois são incorrigiveis, como já o rei-poeta do Antigo Testamento se convenceu, quando em sincera admiração das obras da natureza exclama: "O Jehovah! Quam magnifica sunt Tua Opera! Vir insipiens non cognoscit ea et stultus non animadvertit ea!"

Diz um antigo proverbio: "Natura maxime miranda in minimis!" De facto: no estudo dos seres pequenos e minimos é principalmente que ao espirito investigador se apresentam as maiores maravilhas (1) e não é sem razão que o tal proverbio ficou escolhido como lemma por uma respeitavel e benemerita corporação scientifica do Velho Mundo - a "Sociedade Entomologica da França".

Pertencem os Mosquitos (Culicidae) á classe dos Insectos, á ordem dos Dipteros, isto é, aos Insectos moldados sobre o typo de uma mosca commum e que apparentemente não têm senão duas azas - de onde lhes vem o nome scientifico.

Na realidade existem porém rudimentos das azas posteriores n'uns insignificantes appendices, chamados halteras. São na maioria seres pequenos, dos menores da ordem. Seu apparelho buccal é feito de maneira a permittir-lhes ao mesmo tempo furar, meciante cos pares de cerdas e estyletes chitinosos rijos, dos quaes um - as maxillas se parecem com umas agulhas com ponta farpada, e sugar, mediante um tubo composto de duas peças encaixadas uma na outra a modo de calhas, e provido de uma

(1) * Plus enim - escrevia Santo Agostinho-formicularum et apicularum opera stupemus, quam immensa corpora balenarum.

( De civitate Dei 1.22 , c. 24, n. 5) 
pequena nodosidade, na ponta. Seguem-se aos lados um par de palpos ainda, de variavel comprimento e numero de articulos, e finalmente as antennas, por sua vez assás variaveis quer especif'camente, quer em relação aos dois sexos.

Têm os Mosquitos alguma cousa de commum com as borboletas (Lepidopteros): a posse de escamas. Escamas encontram-se, de facto, tanto sobre as partes do tronco propriamente dito, como nas azas, principalmente ao longo das veias, chegando a sua maior ou menor concensação n'esta ou n'aquella parte, a produzir certos desenhos e ornamentos caracter.sticos, e por vezes até nas pernas.

$\mathrm{Si}$ verdade é, que os pormenores subtis e as delicadas differenças na estructura externa só se revelam nitidamente ao exame microscop:co, sendo assim reservados ao profissional, muita cousa chega-se a vêr com uma lente regular e até a olhos nús, para quem tiver alguma pratica em taes misteres. Eu pelo menos apprendi rapidamente a distinguir com segurança, sem auxilio de vidros de augmento, entre os Culicides amazonicos, individuos d'esta ou d'aquella especie e de ambos os sexos, e já tive ensejo de orientar mais de um medico desta capital no meu gabinete d'estudo, da relativa simplicidade no discernimento e da facilidade de adquirir aquella dose de conhecimentos systematico-zoologicos, que significa o imprescindivel substracto para poder iniciar estudos proprios e independentes no assumpto.

Os membros do famigerado genero Anopheles (1), cada vez mais conhecido como transmissor da "malaria " e do cyclo de molestias que a esta noção pathologica, oriunda de um provincialismo das regiões pantanosas da Italia, se subordinam, conhecem-se pelo seu colorido geral sombrio e pouco vistoso mas principalmente $1^{\circ}$ ) pelos palpos compridos em ambos os sexos, quasi igualando em comprimento a tromba sugadora (proboscida); $2^{\circ}$ ) pelas azas, que pela condensação de escamas escuras em certos logares das veias, revestem um aspecto enxadrezado -, variavel naturalmente de uma especie para outra. São mosquitos relativamente pequenos, morando mais ao ar livre em logares pantanosos, do que principalmente nas habitações humanas, as quaes são só esporadicamente invadidas.

O genero Anopheles é distribuido em 42 especies sobre todo o globo, porém é melhor representado no littoral oriental da America septentrional e meridional, no littoral tropical de ambos os lados da Africa, na parte occidental da Europa, no sul de Asia e na costa oriental da Australia. Antecipando alguma cousa a considerações ulteriores, direi, desde já, que assás significativo é o facto ainda recentemente accentuado pelo mais autorizado monographo dos Culicides: "O quanto eu posso julgar, estou obrigado a dizer, que a presença do Anopheles quadra sempre muito bem com a distribuição da febre malarica." (2)

O genero Megarhinus, distribuido sobre o littoral oriental tropico e subtropico de todos os continentes do hem:spherio sul, allude á tromba extraordinariamente comprida, igualando de perto o comprimento do corpo. São mosquitos assás grandes e bastante distinctos pela sua extranha belleza e vivacidade de colorido; são talvez, os mais

(1) A significação d'este nome generico, tirado do grego, é * inutil ", * imprestavel *, concordando assim assás bem o termo trivial *atôa.

(2) F, V. Theobald, Culicides, vol. I, pag. 118 
bonitos de toda a familia dos Culicides. Caracterisa-os á primeira vista, mesmo a olho nú, um tufo ou pincel de escamas de viva côr carmim ou amarella ou variegada, tufo arranjado horizontalmente a cada lado da extremidade do abdomen como as plumas de uma flexa. São transparentes, com brilho dourado, as azas e as antennas mostram na parte basal uma almofada, unilateralmente provida de escamas, distinctivo este que em verdade.só é perceptivel com o microscopio. Não ha mais que 12 especies, das quaes 1/3 indigena da America do Sul. Dizem que mordem severamente (1), são de habitos diurnos mas como são estrictamente moradores do mato, não perseguem sinão os viajantes, caçadores e lenhadores etc., e não entram nas residencias humanas sitas além da zona silvestre.

Jazem ainda em completa obscuridade os pormenores relativos ao desenvolvimento delles. Um bello animal deveras é o Megarhinus separatus Arribalzaga, de abdomen e tufo vermelho-carmim, apanhado por nós n'uma serie respeitavel de exemplares nas matas circumvisinhas da cidade de Belem: Murutucú, Utinga e no Bosque municipal. Sua mordedura é, como acabamos de dizer em relação ao genero inteiro, reputada dolorosa, sem que a experiencia propria nos autorise a affirmal-o.

Não entrando por ora em detalhes sobre o genero Ianthinosoma (2), por assás subtis os signaes distinctivos em relação ao genero Culex e não possuirem as especies d'este genero, ao que nos parece, conforme as minhas experiencias até hoje, consideravel importancia faunistica, pelo menos aqui na fóz do Amazonas (colleccionei alguns exemplares da Ianthinosoma musica, que, trazida pelos naturalistas da Faraday-Expedition tambem se acha no British Museum de Londres em exemplares vindos de Itacoatiara), merece a nossa attenção o genero Stegomyia (3), incluindo mosquitos de tamanho medio mui facilmente reconheciveis pelo seu colorido rajado de preto e branco, saliente tanto nas pernas anneladas, como no proprio corpo (4). As azas são hyalinas, de um matiz azulado de aço; os palpos do sexo masculino são quasi compridos como a proboscida, curtos porém em individuos do sexo feminino. São de costumes diurnos e largamente distribuidos em 14 especies sobre o littoral tropico e subtropico dos continentes desenvolvidos no hemispherio sul. Mordem severameute e uma serie de apellidos vulgares como "tigermosquito " etc., mostram o odio que o povo, por toda a parte, devota a estes impertinentes e sanguinarios carapanás. Infelizmente aqui na cidade do Pará é por demais frequente, a ponto de ser um verdadeiro flagello, um membro d'este genero, a Stegomyia fasciata - justamente aquella especie que goza de triste celebridade por ser, nos termos textuaes do mais moderno monographo, o agente pelo qual o germen da febre amarella é disseminado (5). Voltaremos a ella.

Segue o genero Culex propriamente dito, que no sentido lato, que Linneu the

(1) Uma especie brasilica chama•se $M$. ferox, uma outra da ilha de Ceylão $M$. immisericors!

(2) O nome é composto das tres palavras gregas 1) «iodos» = roxo e 2) * anthós $=$ flor, estas duas reunidas e 3 ) * sóma s corpo.

(3) Nome de origem grega, significando *mosca que deve ser enchotada, repellida», contra a qual a gente deve se precaver. Outros fazem-no derivar do substantivo grego «stégos» = tecto, casa. $O$ autor do nome, Theobald, nunca deve se precaver. Outros fazem-no derivar do substantivo grego «stégos» $=$ tecto
se pronunciou ao que eu saiba acerca da interpretaça por elle intencionada.

(4) Dizem•me que a $S$. fasciala tem por ahi o nome trivial de * carapaná-pinima s com allusâo ao colorido rajado de preto e branco.

(5) F. V. Theobald: Culicides, vol, 1, pag. 284. (1901-1902.) 
tinha dado em 1758, abrangeria todas as especies que possuem palpos longos no sexo masculino e palpos curtos no sexo feminino e que, mesmo feitas umas recentes reducções, ainda hoje conta nada menos que 125 especies. São por via de regra de colorido pouco vistoso, cinzento amarellado ou branco, sendo as azas hyalinas, transparentes, muitas vezes iriantes. Os seus costumes são geralmente diurnos, apresentando todavia uma notavel excepção justamente o Culex fatigans de Wiedemann, horroroso flagello nocturno aqui $\mathrm{em}$ Belém, nas habitações humanas de certas partes da cidade.

Infelizmente tambem esta especie é altamente suspeita á sciencia medica como provavel transmissor de graves molestias tropicaes. como a filariase. Logo voltaremos a este insupportavel inimigo do nosso socego nocturno, execrando emulo em perversidade da felina Stegomyia fasciata acima mencionada.

O genero Taeniorhynchus, proximamente ligado a genero Culex, distingue-se principalmente pelas escamas largas e espessas, obliquamente truncadas na sua margem opposta á base-portanto caracteres apenas perceptiveis mediante exame microscopico. Cito-o aqui, porque entra nelle um mosquito que diariamente observo nas casas de Belem, ao cahir da noite. E' evidentemente uma fórma crepuscular, que invade a nossa sala de jantar, voando por cima da mesa e por entre os pratos, devagar e pousando, bastante sem cerimonia, na nossa testa, nas mãos, mordendo logo, dolorosamente. E' de indole tão voraz quão ingenua, pois deixa-se esmagar e achatar com a maxima facilidade, não cogitando na fuga em tempo opportuno. O Taeniorhynchus fascicolatus Arribalzálga distingue-se, á primeira vista, pelo seu colorido extranhamente escuro, quasi preto, - colorido este que é produzido, como se verifica pelo exame microscopico, pela densidade das escamas escuras, profusamente disseminadas ao longo de toda a nervura das azas.

Muitás bellas especies contém ainda o genero Sabethes, exclusivamente amazonico ( 3 especies). Conhecem-se á primeira vistal, a olho nú, além do seu colorido metallico, verde (S. longipes) e azulado (S. remipes), pelos vistosos tufos ou pinceis de escamas prolongadas, $\mathrm{em}$ forma de pellos compridos, na parte tibial das pernas.

N'uma dellas rejo brilhar estes tufos n'um magnifico azul-ferrete, orlado de branco.

São mosquitos grandes, vistosos, de habitos diurnos e vida sylvestre. Encontrei e colleccionei d'elles abundante material no proprio Bosque, (Marco da Legua), localidade onde são frequentes a ponto de se tornarem importunos assás, pois mordem ferozmente, deixando no logar da mordedura uma inflammação relativamente intensa, evidentemente pela maior dóse do veneno injectado na ferida.

Podemos deixar de entrar em descripção mais detalhada dos generos Psorophora (todo amazonico), Haemagogus, Wyeomyia e Limatus, pouco numerosos todos em especies sylvestres, ñ̃o muito bem estudados ainda, mas não incommodando o homem senão portas fóra. Apenas o ultimo, Limatus, nos poderá merecer algum maior interesse pelo facto de ter sido creado em virtude do material colligido aqui no Pará, em 1900, pelos drs. Durham e Myers, enviados da "Medical School of tropical Deseases" de Liverpool.

Quatro são portanto as especies de mosquitos que principalmente provocam a nossá attenção, aqui no Pará, como inimigos da humanidade, pequenos de vulto, grandes, 
porém, nos seus effeitos, inimigos que parece terem-se conjurado para roubar-nos o socego, de dia e de noite, torturando-nos não só pela dôr physica, como acarretando-nos gravissimos perigos e males á saúde. Trez d'elles armaram já definitivo acampamento dentro da propria cidade nestes ultimos annos, revezando-se nos assaltos diarios ás nossás habitações humanas, prejudicando enormemente o credito e a reputação de Belem como cidade equatorial de amena habitabilidade; o quarto arassala os arredores e circumrisinhanças, e, ameaçando incessantemente a existencia humana nas regioes pantanosas do interior, $\varepsilon$ apontado pelos resultados modernos da sciencia como vehiculo e transmissor das febres palustres, e, constituindo-se em serio obstaculo ao povoamento do paiz, torna-se directamente culpado de grave lesão á prosperidade publica.

Examinando-os de mais perto um por um, principiaremos pelo ultimo.

No genero Anopheles, (1) todo elle de tristissima celebridade na litteratura medica hodierna, a especie que, conforme as minhas investigações, principalmente nos póde interessar do ponto de vista local paraense, é o Anopheles argyrotarsis Desvoidy (1828), e se não me engano, a raça ou subespecie albipes Theobald (1901).

Mede, com a tromba estendida, uns $7^{\text {mm }}$ e é de colorido sombrio, uniformemente cinzento-branco. (Guiando-se pela estampa I de Theobald, este colorido deveria todavia puxar sensivelmente ao bruno-vermelho-claro sobre o cephalothorax, o que constituiria uma das differenças em relação ao A. argyrotarsis typico, onde a côr do cephalothorax apresenta-se de um cinzento-azulado. Devo declarar entretanto que em exemplares frescos não achei confirmada semelhante differença, que provavelmente se explica por uma imperfeição technica.) Pertence a nossa especie ao grupo ou secção com a margem anterior da aza provida, pela parte de cima, de manchas escuras muito distinctas.

O aspecto das azas é enxadrezado, como súe ser aliás em todo o genero. Distingue-se a nossa subespecie ou raça albipes outrosim por uma larga fita preta no articulo baseal do tarso das pernas posteriores, signal este que não se nota no $A$. argyrotarsis typico. São estes os caracteres principaes, além de outros mais subtis, que permittem reconhecer o nosso mais frequente Anopheles paraense.

Os exemplares que me servem para a presente descripção provêm de Macapá, margem guyaneza do Amazonas, onde foram colleccionados, faz 3 annos, pelo preparador de entomologia do nosso Museu. Havia por lá então uma afflictiva abundancia d'elles e coincidia esta circumstancia com uma epidemia de sezões. Os nossos exemplares são todos do sexo feminino, cheios de sangue a não poder mais, e foram apanhados dentro de casa, e dentro de mosquiteiros jaí não muito preenchedores da sua tarefa. Tanto quanto sei, concordam estes Anopheles de Macapá com aquelle sombrio carapanã, que com tanta profusão encontrei em 1895 durante a expedição scientifica do pessoal do Museu ao littoral da Guyana entre o Oyapock e o Araguary. No Amapá era simplesmente horrorosa então a abundancia de taes insectos.

Pude convencer-me do acerto da affirmação popular que este carapanã sombrio tinha uma predileç̃o pronunciada pela mata de siriúba (Avicennia); de facto, quem

(1) Os mosquitos do genero Anopheles podem ser distingruidos e reconhecidos por uma pessoa leiga mesmo, pela posição por elles assumida no acto da picada. Levantam o abdomen, assumindo o eixo do corpo direcçáo que se approxima mais ou menos da perpendicular. Conservam por outro lado o seu corpo em direcçio mais ou menos horizontal as especie:
de outros generos de Culicides. 
tentasse atravessar um siriubal, mesmo de dia, ficaval logo com o rosto e as mãos pretas de carapanãs que, quaes furias infernaes, em nuvem espessa perseguiam o intruso até que conseguisse salvar-se da zona de mato. Nunca me esquecerei das torturas que n'aquella região soffremos pelos Anopheles, que de noite invadiam a villa. Coincidiu novamente o tempo da nossa residencia com recrudescimento de febres palustres na dita região. Lembro-me de certa casa no Amapá, onde de uma noite para a outra contei 7 casos novos de sezões. E em todo o littoral da Guyana por nós percorrido e de onde pude obter informações fidedignas sempre foi verificado o mesmo resultado empirico, que se impunha com nitidez de não poder ser mal entendida - «onde havia muita febre palustre, tambem havia muito carapanã». Ora, quando pela observação multipla e constante se evidencia a coexistencia de dous phenomenos A e B com o caracter de regra e norma, não é mais demasiada ousadia suspeitar-se um nexo causal entre ambos.

A áreà de distribuição deste Anopheles estende-se no littoral oriental desde o Paraguay e Buenos-Aires até a ilha Jamaica, sendo que nas Antilhas as ilhas Santa Luzia (agora em perigo pela actividade vulcanica do monte Souffrière), Antigua e Granada, com diversos pontos na terra firme da Guyana Ingleza, representam pontos, onde a existencia da especie foi positivamente averiguada sobre material original de lá enviado ao sr. Theobald em Londres.

No Pará (arredores) foi o Anopheles argyrotarsis colleccionado, além de nós, pelos Drs. Durham e Myers, e pelo Dr. E. Austen, dipterologista do British Museum, da Faraday-Expedition, (Boletim do Museu Paraense, Vol. II pag. $386 \mathrm{seg.}$.)

Observações sobre o Anopheles argyrotarsis, especie typica, e sub-especie albipes-(ambos são encontrados, ora simultaneamente nos mesmos logares, ora uma com exclusão da outra) - têm sido feitas pelos Doutores St. George na ilha de Santa Lucia, Grabham na Jamaica, Forrest na Antigua, Broadway em Granada, Rowland na Guyana Ingleza, Lutz no Rio de Janeiro e Săo Paulo, Arribalzaga em Buenos-Ayres Holmberg em Formosa.

Na ilha de Antigua o Dr. Forrest encontrou abundantemente as larvas n'um valle pantanoso e coberto de um capim ("Pará-grass", Panicum muticum Forsk,) e em condições semelhantes as encontrou tambem o Dr. St. George Gray na ilha de S. ${ }^{\text {ta }}$ Lucia (conf. Theobald, Monograph of Culicidae Vol. I, pag. $39 \mathrm{seg}$ ). Distinguem-se as larvas do genero Anopheles pelo tubo respiratorio anal muito curto e os pellos ramificados, grandes e em pares, agrupados de cada lado dos segmentos da parte anterior do corpo.

Já acima alludi á coincidencia singular que ha entre a distribuição geographica da malaria e a do genero Anopheles. Na Inglaterra foi pelo professor Nuttall, em Cambridge, chamada a attenção para as relações entre febres intermittentes em certas regiões com a coexistencia do Anopheles maculipennis; na Italia foram os professores Grassi e Noe que fizeram bellos estudos sobre o nexo causal entre o Anopheles maculipenis e a malaria; ná Africa, ao sul do Sahara, foram os Anopheles funestus e costalis reconhecidos como agentes envolvidos na transmissão da temivel *black waterfever» e o nosso Anopheles argyrotarsis é novamente incriminado da dispersão de febres de máo caracter em Surinam e na Guyana Ingleza. Tudo isto são factos que não podem soffrer contestação. Que se leiam os livros de Theobald, Grassi, Nuttall, além 
das muitas revistas medicas modernas, que constantemente rêm trazendo noros estudos, noras contribuições n'este terreno. E para quem sabe como o professor Kíoch, de Berlim, commissionado especial do governo allemão para o estudo da malaria na Italia, na Africa e nas Indias, n'estes ultimos annos, voltou, mostrando como por uma therapeutica e prophylaxia racional e methodica ha meio seguro de um combate victorioso contra a malaria, não me.levará de certo em conta de grosseria, se confesso francamente, que hoje, um medico residente em região tropica, não cuidando seriamente de acompanhar os progressos da sua sciencia, com a litteratura profissional e o microscopio á mão para seu uso diario, trabalhando assim no seu proprio aperfeiçoamento e em proveito e a bem dos seus clientes, não passa para mim de um-cleploravel traste, cuja rotina escapará tão pouco a sarcasmo das gerações futuras, como os portadores da medicina medieval lograram fugir das ironicas setas do immortal Molière no "Médicin malgré lui »!

E, voltando ao nosso assumpto, não é curioso agora saber, que nas ilhas Barbados e no archipelago das Bermudas não ha malaria e tambem não ha Anopheles?

Ainda não achei um só exemplar de Anopheles argyrotarsis dentro de cidade de Belém. E' porém substituido aqui por um flagello talvez ainda peior, a Stegomyia fasciata, insolentissimo mosquito diurno, que faz inauditas exigencias á nossa paciencia e resignação. E', como acima já dissemos de passagem, um grupo de Culicides caracterisado pelo desenho saliente, rajado de preto e branco. Além dos caracteres geraes já mencionados, direi que possue um colorido geral escuro, em tinta-neutra. A ornamentação typica do cephalothorax consiste em duas linhas longitudinaes medianas, brancas, compridas (I, II) tendo no meio, na parte anterior, uma terceira linha curta (III); de ambos os lados corre em curva lunar uma outra linha (IV, V) para cima, acompanhando parallelamente as outras descle o centro do cephalothorax, até a margem posterior d'este, que é, por sua vez, marcado com uma bem vistosa orla transversal branca. No abdomen vêm-se indicadas as zonas limitrophes entre dois segmentos consecutivos por uns anneis transversaes, claros esbranquiçados, cuja largura poderá importar em $1 / 4$ ou $1 / 5$ de um dos segmentos.

Pelo lado inferior de cada segmento abdominal vê-se, tanto á direita como á esquerda, um grande salpico arredondado branco, de brilho argenteo, scintillante, com furtos de madreperola.

Estriados de preto e branco são tambem os palpos, como as pernas, sobretudo os pares medianos e posteriores; n'estas pernas posteriores, contam-se na parte tarsal, 5 fitas brancas, prateadas, cujas duas terminaes ( IV e V) são separadas apenas por um estreito annel preto no meio. Salpicos prateados percebem-se outrosim aos lados do cephalothorax, na região da inserção das pernas e na cabeça, ao redor e por entre os olhos. As azas, de colorido fundamental de fuligem, são providas de escamas, que ao exame microscopico mostram um feitio assás alongado e estreito. - Em geral os individuos machos parecem ser de um tom ligeiramente mais escuro do que os do sexo feminino.

A distribuição da Stegomyia fasciata abrange grande parte do littoral de uma zona sita entre $40^{\circ}$ lat. N. e $40^{\circ}$ lat. S. Póde-se dizer que é quasi cosmopolita, em relação a cinta tropica e subtropica do Globo, faltando porém nas regiões frias. Onde porém mostra o seu principal centro de densidade, é no continente americano: o sul dos Es- 
tados Unidos com parte do Mexico, costa atlantica até Virginia beach (bacia do Mississipi ), as Grandes Antilhas, e o littoral sul-americano, costa atlantico-oriental. O British Museum de Londres recebeu a Stegonyia fasciata da Hespanha, de Portugal e de Gibraltar na Europa, de Trovancore, Calcutta, Singapore, Madrasta, Birmania e Tokyo, na Asia; Serra Leoa, Lagos, Zanzibar, Durban, Senegambia, Mashonaland, na Africa; de Nova Guiné, de Queensland, Nova Galles do Sul e Victoria, na Australia; de Savannah e Georgia nos Estados Unidos; de Honduras, na America Central; de Jamaica, Santa Lucia, Granada, São Vicente, Cuba e Porto Rico, Bermudas, nas Antilhas; de Nova Amsterdam e Demerara, nas Guyanas; do Panamá; de Manáos (Dr. Durham), do Pará (pelo consul da Inglaterra IV. A. Churchill 11/fev., 1899; dos Drs. Myers e Durham, Austen e Dr. E. A. Gœeldi), do Rio de Janeiro e Santos no Brazil.

Agora exclama o monographo moderno dos Culicides expressamente: "O parasita da febre amarella é disseminado por este mosquito!» (1) De facto, com força de dia em dia crescente, accentua-se na sciencia medica moderna a convicção d'este nexo causal e póde-se dizer mesmo, que para um respeitavel numero de autoridades scientificas, já tomou a feição de certesa. Ha uma pedra de toque, de primeira qualidade, para se julgar d'esta theoria: um mappa da distribuição geographica do mosquito Stegomyia fasciata, coincide de um modo surprehendente com um mappa da distribuição da febre amarella: não ha um ponto do mundo, onde exista agora, ou tenha jamais existido a febre amarella, que não contivesse ao mesmo tempo a Stegomyia. (2)

Isto já por si só não póde deixar de impressionar a quem para usar de um termo drastico popular - enxerga dous palmos adiante do nariz.

A doutrina da relação intima entre a febre amarella e a Stegomia fasciata não é de todo nova, pois um medico norte-americano, Finlay, já entre 1881 - 1886 publicou varios trabalhos n'uma revista dos Estados Unidos acerca dos seus estudos n'este terreno. Não tendo sido porém, no methodo das suas investigações, evitados certos defeitos, tambem os resultados não puderam libertar-se de certas objecções e assim não conseguiram ganhar desde então terreno e acceitação geral. Houre um intervallo em que tinha cahido n'um quasi esquecimento. Mas as recentes operaçães dos norte-americanos nas grandes Antilhas, c a attenção augmentada para as regiões meridionaes da propria União, fizeram com que resuscitasse o interesse para os estudos iniciados por Finlay, Grassi e outros. Hoje os americanos, depois de terem creado um laboratorio especial na itha de Cuba, onde se verificou o bom fundamento das antigas observações de Finlay e tomando a peito as conclusões therapeuticas e prophylaticas, in muce contidas nos trabalhos d'aquelle precursor, organisaram uma campanha methodica e poderosa, para debellar a Stegonyia e, com esta, a febre amarella. Dos bellos resultados assim obtidos os periodicos especiaes no Noro e no Velho Mundo estão cheios e conforme o que se ouve, não está mais longe o dia no qual o saneamento completo da bella ilha, da "perola das Antilhas», serí um fácto consummado.

(1) The Yellow-Fever parasite is disseminated by this snat, "Theobald, Culicides (1001). Vol. I, pas. 293.

(2) Conforme o mappar na obra de Theobald, Culicides. Vol. 1, pas. 292. 
Não se esperará de mim, que eu venha aqui trazer relação detalhada acerca d'esta meritoria e intelligentemente dirigida campanha; basta que eu recommende as estudiosos os numerosos artigos, que com louvavel zelo, a Revne scientifique, de Paris, tem regularmente trazido sobre esta questão, de ha uns dois annos para cí. Ainda no numero correspondente ao dia 16 de agosto de 1902 veio uma noticia circumstanciada sobre o thema "La fiévre jaune et les moustiques", onde o trabalho hygienico agora em pleno andamento na ilha de Cuba é devidamente apreciado.

Pois temol-a aqui, na cidade do Pará, a famosa Stegomyia fasciata, cujo temido nome hoje é tão fallado algures. E temol-a aqui, não talvez sómente em numero insignificante, não e não: é já um horror a sua abundancia.

Nós, no bairro de Nazareth pelo menos, soffremos n'um grau devéras indizivel d'está furia sanguinaria. D'esde o nascer do sol até o escurecer o implacavel diptero persegue-nos dentro de casa, em turmas de 4, 6, 8, 10 e mais, esvoaçando ao rejor da nossa cabeça, espiando qualquer parte descoberta, para nos inflingir a sua dolorosal e logo intumescente picada. Não ha um minuto de tregua desde o clarear do dia até o cahir da noite: ao escrever, ao comer, ao dormir, o inimigo nos flagella e nem um desesperado moto continuo de debater-nos seria capaz de salvar-nos, que não ficassemos logo com o rosto, pescoço, orelhas, mãos e pernas cobertos de ardentes pontos intumescidos, cujo centro indica, apenas visivel, o logar onde o veneno foi inoculado.

Cada um de nós é picado 50 a 100 vezes por dia, no minimo! Não conheço, n'esta cidade, factor e elemento algum tão nocívo e pernicioso actualmente a trabalho intellectual, ao estudo scientifico e á investigação no silencio do gabinete e laboratorio, como esta execranda creatura que se chama Stegomyia fasciata!

"Fasciata é-escreve Theobald, com toda a razão - "um dos mais molestantes e aborrecidos mosquitos do clima tropical e subtropical; a sua picadá é excessivamente irritante".

Lembro-me, que Goethe - o immortal pocta e philosopho, - escreveu n'um dos seus livros, que, ao seu vêr, se alguma cousa pudesse fazel-o proferir uma blasphemia, seria um bando de mosquitos! (Elle alludia aos enxames do Culex pipiens, que em certas épocas se fazem sentir ao touriste que passeia á margem do rio Sale e que eu mesmo, quando estudante ainda na Universidade de Iena, pessoalmente tambem notei.

Ora, se este grande homem chegou a fazer semelhante affirmação, simplesmente porque os mosquitos, em certos logares, e em certos dias e horas, casualmente $o$ incommodaram, jogando-o fóra do rumo das suas meditaçðes e fazendo-o perder o equilibrio sto:co, para não dizer logo al sua cabeça - o que diria o bom do philosopho se tivesse de aguentar só um meio dia ao nosso lado, aqui no Pará, no nosso gabindte, no meio do zumbido das sanguinarias Stegomyias?

Um jornalista francez, que recentemente esteve aqui no Pará, queixou-se em termos amargos a nós do constante supplicio que lhe causavam n'esta cidade as carapanãs, obrigando-o continuamente a coçar-se, contra os mandamentos do bom tom, e causando-lhe uma commixão insupportavel, sobretudo nas pernas. Fiz-lhe sentir que em parte isto elle devia a circumstancia de usar meias pretas, e contei-lhe as recentes disposições do Ministerio da Marinha dos Estados Unidos, ordenando a conselho dos medicos, que as tropas estacionadas nos Estados do Sul e nas Antilhas substituissem a roupa azul e escura por outra clara, alva, em attenção especial aos costumes da Ste- 
gomyia e dos Culicides parentes. (1) Um medico de bordo, inglez, que ultimamente me veio pedir certas informações de historia natural, demorando-se talvez uma hora na sala da bibliotheca e no meu gabinete, não achou outra expressão para significar-me a sua gratidão, senão esta: "Tenho sincéra compaixão do collega de ter que aguentar a vida n’um logar com tanto mosquito!" E a commissão de medicos da "Liverpool Medical School of Tropical Deseases", bastante em contradicção com o que a imprensa diaria d'aqui dizia acerca dos motivos que levaram-na a mudar o centro de observações para as Antilhas, n'uma brochura posterior, relativa ás condições sanitarias da cidade do Pará, emittiu conceitos que se não são francamente alarmantes, todavia são assás relevantes para merecer a attenção apprehensival das auctoridades, da classe medica e do publico instruido em geral. Falla-se n'esta brochura da Stegomyia, alludindo ao grau de insupportabilidade que attinge aqui a incessante perseguição soffrida pelo homem por parte do feroz e famigerado diptero e quem sabe ler entre as linhas, aproveitaveis liçð̃es ainda poderá tirar d'alli.

Tánto quanto se sabe até hoje acerca da larva da Stegomyia fasciata, vive ella em buracos, poços, depressð̃es do solo etc. contendo agua relativamente limpa. Possue uma cabeça mais ou menos quadrangular, um corpo que conserva o mesmo calibre até o ultimo segmento abdominal, e um siphão respiratorio não muito consideravel. Os oros da Stegomyia, postos isoladamente, são da forma de ellypsoide muito alongado e possuem ao exame microscopico, na peripheria uma serie continua de umas vacuolas claras, consideradas camaras de ar.

Segue em importancia e insupportabilidade como "pendant" nocturno o $\mathbf{C u l e x} \mathbf{f a}$ tigans WViedemann. Não é lí no genero Culex, na sua extensão systematica moderna, cousa muito commum o regimen nocturno; constitue pois, póde-se dizer, uma excepç̃o, visto que é de dia que a maioria exerce a sua abdominavel profissão de vampiros.

Conhece-se esta especic de carapanã relativamente grande, por um colorido geral bruno-castanho; sensivelmente mais ruivo é já o cephalothorax, onde com uma lente commum se percebe o avelludado de uns curtos cabellos com reflexos dourados, faltando apenas na parte mediana anterior, onde a superficie se apresenta como pellada e atravessada longitudinalmente de duas linhas escuras em relevo. Os limittes entre os segmentos abdominaes são marcados por uns distinctos anneis de côr vermelha-amarellacea clara, contrastando bem com o tom bruno escuro do resto do abdomen. Azas um pouco fuliginosas, aliís hyalinas, nervura pronunciada por linhas escuras; pernas, palpos, proboscida e lado inferior tudo de um bruno claro, uniforme, sem desenho ou ornamento qualquer essencialmente notavel. $\mathrm{O}$ macho, um pouco mais delgado do que a femea (cousa que aliâs se dá igualmente nos outros Culicides), ostenta phenomenal penacho ou pluma nas suas antennas, muito mais vistoso do que nos machos da Stegomyia, e fazendo concurrencia, n'este sentido, com os machos de genero llegarhinus.

A distribuição geographica do Culex fatigans muitissimo se parece com a da Stegomyia fasciata; tambem por este lado quer ser seu companheiro insepararel. Ha

(1) Escreve Theobald: "Roupa escura devia portanto ser abolida, quanto possivel. em todas as regices onde os mosquitos se tornam um aborrecido tlagello*. (Culicides. Vol. I, pdg. 61.) Em sentido semelhante pronuncia-se o Dr. Durham loc. cit. pag. 9. Ambos estes autores declaram, que por experiencias ficou demonstrado, que é da. còr amarella que os mosquitos menos gostam. 
uma multidão de sub-especies e raças que se podem distinguir entre os individuos provenientes de diversas partes do mundo; não entraremos nestes pormenores, contentandonos de constatar que os exemplares d'aqui do Pará, correspondem á fórma typica. O Culcx fatigans é proximo parente e mui parecido com o Culex pipiens europeu, que para Linneo é o prototypo da familia, logo reconhecivel entretanto por outros distinctivos na nervura das azas (primeira cellula submarginal e segunda cellula posterior com as suas respectivas pontas interiores quasi em linhas perpendicular).

Limitar-me-ei a enumerar as localidades da America do Sul, de onde houve exemplares de Culex fatigans scientificamente identificados: Panamá -, Demerara, Pará (Churchill, Austen, Durham (1), Goeldi) - Rio de Janeiro, - Buenos-Ayres e Republica Argentina.

Do Dr. Lutz, Director do Instituto Bacteriologico de São Paulo, acha-se na obra de Theobald a declaração de que esta especie representa o mosquito nocturno commum no Brazil, encontrado por toda a parte e picando de noite sómente. Aqui na cidade do Pará é simplesmente pasmosa a frequencia d'este insolente carapanã nocturno: no bairro de Nazareth elle, em nuvens de myriades, assalta as casas, nas primeiras horas da noite, invadindo por janellas e portas, esbarrando qual farinha jogada a todo momento, com intenção offensiva, revoltantemente manifestal, contra o nosso rosto.

A muzica ou zumbido produzido simultaneamente por milhares de carapanãs voando e fazendo verão, n'um quarto escuro, é capaz de fazer arrepiar-nos o cabello! Com bastante razão Plinius, naturalista e escriptor quasi contemporaneo de Jesus Christo, chamou-a de «truculenta»! E apprehensivo cada vez me torna esta odiosa musica, quando penso nas funestas consequencias sanitarias de que ella é, na minha firme convicção, fatal precursoral e mensageira!

Aos milhares os temos todas as noites nos quartos de dormir e se centenas matámos por via de regra - lembro-me que certa noite matou-se, n'um só quarto, em pouco tempo nada menos do que 143 individuos d'este carapanã - sobram muitas centenas ainda, aptas a tornar um verdadeiro supplicio a noite, durante a qual o repouso do corpo é um postulado hygienico inadiavel depois de um dia cheio de trabalho physico ou intellectual com as dobradas exigencias de energia originadas do effeito de um clima equatorial.

De que vale e serve a relativá frescura da noite, aqui no Pará, quanclo não se póde dormir por causa dos mosquitos! -

Mas não é sómente pelo lado da dôr physica pela picada e da impossibilidade de um somno restaurador, que o Culex fatigans se mostra inimigo do homem: inflingethe invisivelmente prejuizos ainda muito mais graves. Pelos seus recentes estudos o Dr. Ronald Ross, medico militar nas Indias inglezas, demonstrou que o Culex fatigans, o "grey mosquiuito" hospecla um singular parasita do sangue, conhecido pelo nome scientifico de Proteosoma (Labbé), e hoje Henoproteus danileaskyi Kruse, e provou esperimentalmente a transmissibilidade do parasita para as aves e reptis, pela inoculação

(1) U Itr. Iurham, no momento de redigir o seu artigo * Notas sobre as condiçoes sanitarias do Para s (ouubbro 1901) ainda nảo conhecia o nome d'este carapana ( a brown one at present unnamed $\%$ ), mas da sua descripção issís detalhada, vïse logro. que elle naio se referia a nenhum outro senāo ao Culex faligans. IViedemann (pag. 6 ). 
directa mediante a picada do insecto (1). Outrosim o Dr. Manson descobriu recentemente toda a historia da vida de um pequeno verme (nematode), parasitario do sangue do homem, a Filaria sanguinis hominis - hoje Filaria Bancrofti-e poude constatar que o Culex fatigans é o intermediario, vehiculo e transmissor de semelhante parasita (2). Ora, a filariasis é uma molestia que causa uma mortalidade consideravel nas regiōes tropicas e subtropicas. São sobretudo a raça preta e os seus cruzamentos que parecem ser de preferencia perseguidos por esta traiçoeira e perigosa molestia. E conselhos d'esta experiencia empirica emanados, apontando para o perigo que ha aqui no Pará, quando pretos e brancos dormem na mesma casa, infestada deste carapanã, nem ao menos fazendo uso do mosquiteiro, d'estes conselhos encontram-se na curta mas substancial brochura já por diversas vezes citada dos Drs. Myers e Durham da « Liverpool Medical School ".

E pela obra de Theobald e os escriptos dos medicos mencionados verifica-se mais uma vez que, quasi por toda a parte onde a filariase é molestia corrente, lá tambem o Culex fatigans é o mosquito nocturno predominante - "essentially a household form". De maneira que, tambem aqui, notamos a concordancia já duas vezes encontrada e tão significativa entre a distribuição geographica de uma certa molestia e a de certa e determinada especie de mosquitos. "A bon entendeur salut."

Restando-nos ainda a quarta especie de carapanã, já acima denunciada como fazendo-se sentir aqui nas habitações humanas na hora do crepusculo, o Taeniorlyynchus fasciolatus Arribalzaga, podemos completar o seu retrato physiognomico do seguinte modo: semelhando em tamanho e aspecto geral a um Culex fatigans do mesmo sexo, differe por um colorido de fundo de um bruno muito mais escuro, interrompido em certos e determinados logares por uns anneis e zonas claras branco-amarellaceas. Uma d'estas - a larga fita branca no meio da proboscida, (que tambem mostra extremidade branca ) - permitte todavia distinguir logo á primeira vista o nosso carapanã do anterior e de caracterisal-o como membro do genero Taeniorhynchus: pois este nome generico, tirado do grego, não pretende ter outra significação senão esta: «fita na proboscida». Nas pernas nota-se um annel claro distincto na parte apical do femur de todos os tres parres; a tibia é atravessada por uns 6 anneis claros nada apertados e, nos tarsos costuma apresentar-se em tal modo clara a zona limitrophe entre cada dois articulos consecutivos, e particularmente vistosa, destaca-se a articulação tibio - tarsal das pernas anteriores.

No cephalothorax contrasta na parte anterior a sombria côr de fundo com uma ornamentação em fórma de $\mathrm{V}$ virado, feita com uns pellos dourados, claros.

De bellissimo effeito é, no animal vivo, a côr verde-escura dos olhos facetados.

No abdomen, escuro, quasi preto, os limites entre os segmentos são guarnecidos de uma corôa de pellos compridos, amarellados claros, luzentes; aos flancos nota-se em cada segmento um salpico branco, correspondendo com um desenho branco em fórma de escala, que se estende sobre os segmentos abdominaes, pelo lado inferior.

(1) Theobald. Culicides 1 paer. 83, seer., par. - Vol. II, pag. 16, seg. Ross, «Indian Medical Gazette », Vol. 33, I)cz. 1898 e Vol. 34, Jan. 1899, e muitos outros artigos do mesmo auctor.

(2) Theobald, Culicides I. pag. 88 Vol. II, pay. 161. Manson, Journal of Linnean Society, Vol. XIV, pag. 3ol

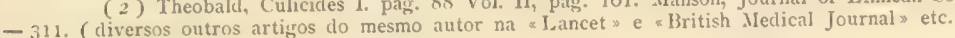


Noto que os individuos de Taeniorhynchus fasciolatus, aqui por mim observados no Pará, differem do desenho colorido n. 121 do atlas da obra de Theobald por um tom mais escuro, circumstancia que aliás já foi mencionada pelo proprio autor: « Specimens from the lower Amazon are for the most part rather browner than one from Rio.» Vol. II e pag. 194).

Taeniorhynchus fasciolatus é uma especie restricta á costa oriental da parte tropica e subtropica da America do Sul.

Foi colleccionado e identificado em especimens vindos do Amazonas inferior (Austen),-Pará (Gœeldi),-- Rio de Janeiro e São Paulo (Lutz) - Republica Argentina (Navarro).

Theobald cita a seguinte communicação do Dr. Lutz: "Este é um verdadeiro mosquito dos pantanos, commum no littoral; pica dolorosamente de preferencia atravez das meias e ao anoitecer, ou então na sombra, durante as horas do dia. Tenho-o do Rio, São Paulo e Santos." (Th. II, pag. 144). Concordo com isto, accrescentando tambem que aqui no Pará é uma fórma crepuscular que invade as casas. Que as picadas d'estes carapanãs são dolorosas, sabem-no as nossas crianças, que na hora do jantar muito se queixam dos seus constantes ataques ás pernas. Têm, como já acima alludi, indole sanguinaria, porém ingenua e phleugmatica, para não dizer redondamente estupida.

Creatura exclusivamente atlantico-sul-americana ao que parece, conforme o actual estado de conhecimentos scientificos, não foi até hoje apanhada em flagrante, pela medicina indigena, em nefasta coparticipação na transmissão de molestias infecciosas Mas, francamente dito, não a tenho em bôa conta e julgo-a tĩo capaz de prejudicar a nossa saúde, como os trez anteriores e tantos outros, quer auxiliando-os na incubação e transmissão das molestias já mencionadas, quer na de outras, talvez nem suspeitadas ainda hoje em dia.

\section{B. - Biologia dos Mosquitos.}

Linneu, em 1758, condensou o estado geral dos conhecimentos sobre esta materia. n'aquelle tempo, em uma phrase curta: "Culicis larvae plerumque ia aqua degunt e Pupae moventur agiles. » Para o fim que temos em vista é, todavia, preciso que entremos um tanto mais nos pormenores do seu cyclo de desenvolvimento.

A femea do mosquito, repleta de sangue sugado, dias antes, ao homem ou a um animal vertebrado superior, (sangue que durante uma gestão de uns 3 para 4 dias parece ser despendido e gasto no crescimento dos ovos no estado intra-ovario), sentindo chegar a sua hora, pousa em cima do espelho da agua de qualquer poça que lhe parece idonea, e principia a pôr os ovos, um por um, até esgotar-se o thesouro ovarial. Conforme as observações de outros, confirmadas por mim aqui no Pará, a postura se realizal durante a noite: é sempre de manhan que eu encontro o facto consummado, sem ter conseguido jamais até hoje testemunhar de vista o proprio acto.

Variando sensivelmente os detalhes biologicos de uma especie para outra, considerei n'estas linhas principalmente as especies paraenses, para as quaes no capitulo anterior acabo de apontar como em primeira linha merecedoras da nossa attenção, po- 
dendo para este fim utilisar-me de estudos originaes por mim organizados no Museu durante os ultimos mezes.

As especies do genero Culex costumam pôr os ovos em grandes massas, em fórma de jangada ou bóte, (1) perfeitamente visiveis a olho nú, pois são de um tamanho tal, que quasi não se comprehende como um corpo tão consideravel podia ser fornecido por um insecto que apparentemente não possue dimensões muito mais avantajadas.

Fluctuam sobre a agua magistralmente; não pódem molhar-se em virtude de garantias especiaes com que a natureza as dotou: tentando submergil-os, qual cysne, enxutos sempre, reapparecem logo á tona. Os naturalistas que se occuparam com o assumpto (entre elles merece menção Réaumur que faz bem 150 annos profundos golpes de vista lançou no desenvolvimento de tão subtis insectos), indicam 200 para 400, como formando a norma habitual do numero de ovos constituindo uma jangada, por exemplo do Culex pipiens, europeu. Contei ainda estes dias os ovos de duas jangadas do Culex fatigans, postas no captiveiro: uma tinha 270 , a outra 225 . Trez ou quatro outras foram avaliadas como movendo-se nos mesmos limites. Os ovos do Culex pungens da America do Norte (synonymo do nosso $C$. fatigans conforme Theobald), medem pelo que escreve o Prof. Howard, que detalhados estudos fez, $0,{ }^{\mathrm{mm}} 7 \mathrm{em}$ comprimento e $0,{ }^{\mathrm{mm}} 16 \mathrm{em}$ diametro na base. Alguns ovos do Calex fatigans do Pará por mim medidos dão na media $0,{ }^{\text {,mm}} 71$ em comprimento (valor medio de 3 ) e $0,{ }^{\text {mu }} 16$ de diametro na base (valor medio de 3 ), valores que, como se vê, quadram magnificamente com os obtidos por Howard em 1900.

São na sua fórma uns cones muitos estirados, comparaveis ás conhecidas sementes do pinheiro do sul (Araucaria brasiliensis).

A côr é fuliginosa, bruno claro, com uma zona clara na ponta. Os ovos, virados com a parte grossa para baixo, contra a agua, são revestidos na sua ponta fina, dirigida para fóra em sentido opposto, de uma bolhasinha transparente de ar - apparelho evidentemente hydrostatico, destinado a evitar a submersão do ovo. Não é grande a coherencia entre esta associação, frouxamente arrumados todos em uma só camada; com uma agulha de dissecção chega-se facilmente a desligar uma porção desejada.

Os ovos de Stegomyia fasciata, do carapanã de perna rajada, jå não são postos em pacotes ou jangadas, mas isoladamente e irregularmente sobre a superficie d'agua, as vezes parecendo arrumados em fórma de estrella. O ovo da Stegonyia é horizontalmente deitado, o do Culex fatigans, verticalmente em pé. Tambem differe na côr, pois é escuro, quasi preto; e bem assim na fórma, pois é um ellipsoide estirado com dous polos rombos, e ñ̃o um cone. Em vez de uma bolha de ar na ponta fina, como no $C$. fatigans, possue o ovo da Stegomyia toda a sua superficie revestida de pequenas vesiculas transparentes ou camaras aéreas, visiveis sobretudo no exame microscopico,

(1) Conviria a comparação com um pedaço de polpa fresca do còco da India, não só em relação á fórma da calotte, como tambem ainda a respeito da estructura fibrosa, no sentido radial, pois os ovos na jangada sào orientados no mesmo sentido radial. 
na peripheria. Finalmente são sensivelmente menores, pois não medem mais do que $0,{ }^{m m} 53$ no comprimento (valor médio de 4) e $0,{ }^{\text {mum }} 15 \mathrm{em}$ diametro (valor médio de 3 ovos).

O numero de ovos attribuireis a uma postura de umá só femea, calcúlo conforme observações até agora, em 50 para 100 mais ou menos.

Não consegui ainda observar a postura do Taeniorlynnchus fasciolatus, mas espero que o conseguirei dentro em pouco. (1)

Não possuo ainda observações proprias sobre a postura do Anopheles argyrotarsis. Mas visto que foram muito bem estudados sob este ponto de vista o Anopheles maculipennis, na Europa por Grassi, e na America do Norte por Howard, não hesito em declarar que em seus contornos geraes os resultados obtidos sobre aquella especie são directamente applicaveis tambem á nossa especie amazonica.

O Anopheles põe os seus ovos isoladamente como a Stegomyia; são uns 40 até $100 \mathrm{em}$ cada postura. Medem $0,{ }^{\mathrm{mm}} 5 \overline{5}$ em comprimento. Semelhando na sua fórma ellipsoidal estirada á do ovo da Stegomyia, é caracterisado á primeira vista o ovo do Anopheles por duas azas lateraes no eixo menor, desiguaes no seu aspecto superior e inferior, difficeis de descrever, mas não representando certamente outra cousa seño um apparelho de reforço local d'aquelle mesmo systema de camaras aériferas, já encontradas no ovo da Stegomyia.

\section{$* *$}

Precisam de dois dias as jovens larvas, para sahir do oro. (2) São creaturas pequeninas, transparentes, muito ageis, movendo-se por contracção e distracção executadas ora para a direita ora para a esquerda. Ha meio de conhecer as larvas de Culex, Stegomyia e Anopheles desde a mais tenra idade. As de Culex fatigans, por exemplo, por um tronco que se vae afinando no sentido antero-posterior; possuem uma cabeça em fórma de um trapezio bastante achatado, têm um siphão respiratorio muito comprido. Em comparação com as figuras dadas por Howard e Theobald noto nas

(1) Com summa satisfação reysistro aqui que ainda durante a redacção do presente trabalho a mencionada litcuna foi preenchida. A massa de oros do Taeniorbynchus fasciolatus fórma um fio fino, de uns $x^{\text {me }}$ de compriclo, com dupla fileira de oros sómente.

Cada fio - contei dous - costuma conter uns 100 ovos aproximadamente, (I: 54 series duplas $=108:$ II: 5. series duplas $=104$.) Os oros são côr de fuligem escura. Na sua fórma parecem-se com as garrafas de champaçne, urraçà a 'seu polo anterior estirado.

As camaras aéreas revestem. qual rede de malha, toda a superflcie, como no caso do oro de Slegomyia, (divergindo desta porém por sua fórma). Medem $0^{\text {am }} 68$ no comprimento (valor medio de 3 ovos medidos) e $0^{\mathrm{mm}} 14$ de ları́ri (valor medio de 6 oros).

As larvas levam 2 para 3 dias para sahir.

Continuo a estudar-lhes o desenvolvimento.

Ainda faz poucos mezes escrevia Theobald, o melhor conhecedor dos Culicides do mundo todo, na descripçio geral do genero Tieniorbynchus: z Nada absolutamente se sabe até hoje a respeito dos oros, das larvas e pupas de gualquer especie deste genero. (Culicidae (1901), vol. II, pas. 190).

IIa pois, mais esta descoberta scientifica indiscutivel a lançar no saldo da actividade do nosso Museu. l3elem do l'ari, 30 de setembro de 1902.

(2) O lapso de tempo minimo observado até hoje é de 16 horas. 
minhas larvas que as cerdas compridas extendem-se não sómente em 8 pares sobre o cephalothorax, mas ainda sobre os dous anneis abdominaes seguintes.

Hedem ao nascer $1 .{ }^{\mathrm{mm}} 6$.

As larvas de Stegomyia fasciata têm um tronco que desde o cephalothorax até a parte anal conserva mais ou menos o mesmo calibre, calibre este que, ao contrario do que se dá na larvá de $C$. fatigans, não destôa lá muito do da cabeça e do cephalothorax; o siphão respiratorio é de comprimento mediano.

As larras de Anopheles distinguem-se pelas suas cerdas compridas quando novas, e ramificadas na parte anterior, quando mais velhas; o siphão é curto, porém as cerdas anaes são extraordinariamente desenvolvidas.

Vivem estas larvas de materias organicas finamente distribuidas e em suspensão na agua; são algas de diversas categorias (limo), folhas em decomposição, pelles vasias de larvas etc. e ao que parece tornam-se culpadas de actos de cannibalismo, as maiores devorando as menores.

Ha agora na economia d'estas larvas um facto importante: apezar de aquaticas, dependem de respiração aérea, morrendo infallivelmente quando esta the é vedada.

Todas estas larvas têm uma necessidade imperiosa de frequentar amiudadas rezes a superficie ou então conservam-se de uma feita na sua visinhança.

Curioso é vêr-se a differença que se nota entre as larvas do Anopheles de um lado e as do Calex e generos parentes por outro. As larvas de Culex são ao que parece, de um peso especifico maior do que a agua; não remando, com os seus movimentos flagellantes, a larva sempre cahe ao fundo, e uma vez lá não consegue sahir outra vez, senão mediante visivel esforço muscular.

Entretanto ellas fazem esta viagem para a tona d'agua a todo o momento, perto de minuto a minuto. Larva que não o faz e que não está fornecida do necessario vigor e robustez, é doente, perdida; afoga-se.

Parece um paradoxo, mas é incontestavel que um animal aquatico assim póde afogar-se.

Subindo á tona, conservam-se em posição obliqua de uns $45^{\circ}$ contra a vertical, cabeça para baixo, dous possantes apparelhos ciliares ao redor da bocca, em constante movimento rotativo, quaes turbinas, levando particulas nutritivas para aquelle sorvedouro insaciavel; o siphão respiratorio virado para cima, chegando ao ar livre e aprovisionando-se assim novamente, como locomotiva mediante manga d'agua, parada em frente de um deposito.

Embora a necessidade das larvas de Culex e de Anopheles de prover-se de ar na superficie seja a mesma, comtudo o modo de comportar-se entre ambas é assaz diverso. Ao inverso do que temos visto em relação ás larvas de Culex, a do Anopheles, nutrindo-se de preferencia de materias fluctuantes, leves, tem ao que devemos julgar, um peso especifico semelhante ao da propria agua, pois ella detem-se principalmente na camada superior, perto do espelho d'agua. Em vez de posição obliquamente inclinada, observa de preferencia a horizontal, com o siphão réspiratorio para fóra. (1) Para descer ás

(1) Exquisito é o costume de larva do Anoplseles de conservar a maior parte do tempo a cabeça torcida em $180^{\circ} \mathrm{em}$ relaçâo ao eixo do corpo, ou em outros termos, de ostentar o rosto virado contra as costas. 
camadas inferiores d'agua - o que faz, quando se sente perseguida - ella precisa tão visivelmente um esforço muscular, como a larva do Culex necessita no sentido contrario.

Em condições normaes ou favoraveis, isto é, quando o tempo é bom e ha fartura de alimento, crescem as larvas á vista d'olhos. Mudando de pelle por diversas vezes, trocando a velha sempre por uma nova, mais folgada, a larva do Culcx póde estar adulta depois de 7 a 8 dias.

A larva do Anopheles, porém, que precisa, conforme Howard. tambem um dia mais para sahir do ovo, leva o dobro, 16 dias.

Segue-se o estado de chrysalida ou de pupa. E' um ser inoffensivo, condemnado a uma vida meramente vegetativa, pois não póde tomar alimento, tendo cabeça e cephalothorax enrolados e envolvidos n'um envoltorio chitinoso, especie de sacco, do qual nada sahe senão um par de siphões respiratorios no thorax, tendo agora a fórma de piston, e um abdomen longo com remos anaes, parecendo com o abdomen de certos camarões. Mantém-se perpendicularmente n'agua e destaca-se de longe por sua côr escura. Em posição, fórma do olho, tamanho do sacco mencionado, feitio do siphão, revestimento de cabellos mais ou menos curtos, notam-se differenças sufficientes para permittir logo reconhecer se temos diante de nós uma chrysalida de Culex fatigans ou uma de Anopheles.

O Culex fatigans não precisa mais do que 2 dias para a phase de chrysalida; o Anopheles maculipennis necessita, ao que assegura Howard, bem cinco dias para a mesma phase.

Surge finalmente o insecto perfeito.

O Carapanã alado, completo, que rebentando a casca, liberta-se por uma fenda dorsal da prisão estreita e incommoda, n'um quarto de hora mais ou menos e levantando o vôo, com presteza se affasta de seu berço natal e desde já trata de cuidar da sua propria existencia.

Desenrola-se assim todo o cyclo do desenvolvimento no Culex fatigans em 11 dias redondos, ao passo que o Anopheles maculipennis no caso da experiencia feita pelo professor Howard em maio de 1900 na Virginia, 24 dias, portanto mais do que o dobro. (1) Verdade é, que o mesmo autor suspeita, que em estação mais quente o cyclo do Anopheles levará bastante menos tempo, e estou tambem convencido, de que realmente a processo se abrevia consideravelmente aqui na zona equatorial.$$
\therefore \%
$$

(1) Nuttall e Shipley (Studies in relation to Malarid 1901) acharam tambem 20 a 25 dias na Inglaterra (pag. 275 ); Grassi (Malaria, pag. 92 ) indica como norma, na Italia, um periodo de 25 a 26 dias, para umo temperatura nå oscillando além de 25 a $28^{\circ} \mathrm{C}$, alleırando a abreviaçăo com temperatura mais elevada.
} 
Dous, dizia Gœethe, são os eixos grandes do mechanismo d'este mundo: a fome e o amor. Se ha onde este axioma se possa descortinar com toda a nitidez e acha sua applicação literal nua e cruá, é na vida dos mosquitos, como passamos a demonstrar.

Sahido o mosquito da chrysalida ou pupa, e endurecidas devidamente as suas azas e toda a sua carapaça chitinosa, em contacto com o ar, durante algumas horas, principía a sentir fome e trata de procurar alimentação. Visto que a alimentação no reino dos insectos costuma ser de natureza vegetal, não ha para mim duvida, que desta regra não se exceptuaram primitivamente, em tempos geologicos anteriores, os Culicides e alguns outros grupos isolados tanto da propria classe dos Dipteros, como de outras, entre as quaes hoje encontramos a haemaphilia como um costume profundo e tradicionalmente arraigado no seu caracter. Logo voltaremos a este assumpto.

Phenomeno curioso agora é a differença existente no modo de se alimentar entre mosquitos do sexo masculino $\mathrm{c}$ os do sexo feminino. Os primeiros procuram fructos maduros e flôres, lá fóra na natureza, e visitando as nossas casas, frequentam o assucareiro, café, chá, vinho, caldos, nas chicaras, pires e pratos das nossas mezas, todas as substancias doces enfim, abstendo-se por via de regra, de chupar sangue. Os individuos do sexo feminino, participando, até certo ponto d'este regimen, todavia são simultaneamente dados ao vicio de chupar sangue; são estes de preferencia, que nos fazem mal e contra elles em primeira linha é que se volve o nosso odio, fructo do desespero.

Sendo, como acima fizemos ver, facil, de reconhecer sempre o sexo masculino nas diversas especies de mosquitos, pelas suas antennas decoradas com vistosas plumas, ao passo que as femeas mostram sómente, á simples inspecção a olho nú, bem distincta, entre as partes buccaes, a proboscida ou tromba, em fórma de estylete comprido, recto ou ligeiramente curvo, qualquer pessoa e em qualquer hora poderá convencer-se do acerto do que acabo de affirmar. Ha uns mezes, fiz o seguinte experimento significativo: vendo de noite, o assucareiro em nossa mesa envolvido n'uma nuvem de carapanås, e verificando que bom numero já se achava lá dentro, tampei subitamente com um pedaço de papelão e introduzi, por uma abertura previamente arranjada, um pouco de algodão embebido com algumas gottas de chloroformio. Minutos depois verifiquei o resultado: 37

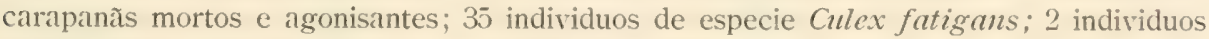
de Stegomyia fasciata; 34 exemplares machos, 3 femeas (sendo uma de Stegomyia, 2 de Culex fatigans.) Era isto na sala de jantar.

A maioria enorme portanto era constituida de machos d'aquella especie de mosquitos que aqui no Pará nos molesta principalmente de noite.

E quantas vezes esta experiencia será repetida, tantas vezes o resultado será o mesmo, com insignificante variação na porcentagem dos representantes de um e outro sexo.

Fiz, ha dias, uma experiencia complementar. Notando alta noite, que uma certa parte do nosso mosquiteiro, circumvisina ao meu rosto, estava pelo lado de fóra, crivado por assim dizer de carapanãs, sapateando afflictos para cima e para baixo no manifesto e conhecido empenho de descobrir um furo ou buraco bastante grande, para lhes permittir o ingresso e de me picar, por uma subita inspiracão, com violenta tapona com a palma da mão, achatei uma porç̃̃o d'elles contra a parede, encostado á cama. Levan- 
tei-me e contei o resultado: 23 individuos mortos, de Culex fatigans, todos do sexo feminino! E era isto no quarto de dormir.

E assim sempre será, quando procuramos averiguar, quál a relação numerica dos dois sexos entre os carapanãs que invadem os nossos quartos de dormir: enorme maioria, até a exclusividade, de individuos do sexo feminino entre todas aquellas șurprehendidas no exercicio effectivo ou intencionado de chupar-nos o sangue - esta seiva de todo especial, no dizer de Gœethe, na mysteriosa linguagem symbolica do "Faust".

Todos os autores que tivemos occasião de conpulsar a este respeito, sĩo concordes em declarar que é muito difficil de explicar porque ha entre os Culicides semelhante gosto para chupar sangue, restricto mormente ao sexo feminino (Howard pag. 12, Theobald pag. $69 \mathrm{seg}$.) (1) Não é tão difficil, ao meu ver: poucos leitores haverá, que jí não tenham tido ensejo de observar, especialmente aqui n'um clima tropical, como uma qualquer escoriação, ferida em partes expostas do corpo é perseguida por uma turba de pequenas moscas e insectos parentes, que vêm sorver o serum do sangue substancia um tanto adocicada. Igualmente sabe-se como os cantos dos olhos por exemplo dos mammiferos maiores durante certos periodos estivaes, são perseguidos pelos mesmos dipteros impertinentes, que vêm attrahidos pelo "humor aqueus " com que o globo ocular é humedecido com vistas á sua funcção rotativa. Ora, todos estes pequenos Dipteros, de par com diversas moscas de tamanho vulgar (Stonoxys etc.) e outras grandes, como as Tabanides, indicam-nos o caminho percorrido pela haemaphilia: os Culicides, primitivamente sómente procurando seivas adocicadas, travaram conhecimento com o sangue animal, mediante o serum sanguineo de feridas e contentando-se os machos com este, as femeas foram a ponto de praticar intencionalmente perfurações da pelle, para se metterem em posse do liquido desejado.

Secundadas n'este mistér por um apparelho buccal positivamente mais robusto, melhor perfurante do que o do macho, e utilisado proveitosamente o liquido assim, de modo tão facil e barato obtido, como viaticum para as augmentadas exigencias do trabalho physiologico da postura dos ovos e consumo material que d'ahi deriva, uma disposição para este procedimento devia facilmente tornar-se em costume e habito arraigado, em regra e norma, em postulato indispensavel finalmente. E não são poucos os exemplos que, na serie animal, podemos allegar de estranhos casos e por vezes inauditas exigencias, que a reprodução da especie põe ao sexo feminino: as ultimas proglottides de uma Taenia (solitaria) nada mais são morphologicamente senão um enorme armazem de ovulos; - em certas Anguillulas entre os vermes nematoides (aos quaes pertence a Meloidogyne exigua, causadora da molestia do cafeeiro no sul do Brazil ) a femea transforma-se em sacco disforme repleto de ovulos; - nos Coccidios (pulgões parasitarios dos vegetaes) a femea finaliza a sua existencia individual, dissolvendo-se em um montão de ovos e larvas novas, coberto pelo disco dorsal da mãe como um escudo protector. São tres exemplos, onde a mãe se sacrifica litteralmente no interesse da sua prole, n'um grau que surprehende o nosso sentimento humano, pois significa nada menos do que a completal dissolução material do corpo materno em descendentes. 
A' luz de uma consideração comparada sobre outras ordens e classes do reino animal diminue, ou antes desapparece, por completo a difficuldade acima alludida. A sucção do sangue, adquirida accidental e secundariamente como habito, tornou-se um factor essencial da sua vida em relação á maturação dos productos sexuaes da femea: hoje estes insectos precisam de sangue para a propagaça da sua especie.

Mluitos leitores já terão assistido á expulsão de um novo enxame de uma colmea de abelhas, e á sahida dos zangões, como sem duvida terão tambem assistido á sabida das "iç̃̃̃s" ou "tanajúras" de um reino de formigas saúvas. Aquelle grandioso fervilhar de innumeros individuos alados no ar, "fazendo verão", como o povo costuma dizer, não é outra cousa, senão o hymeneu d'estes insectos, pois n'aquella occasião e no ar dái-se o encontro dos individuos de ambos os sexos.

Exactamente da mesma fórma se explicam os enxames de mosquitos que se nota entrando, ao anoitecer, pelas janellas e enchendo os nossos quartos de um funesto zunido: estão celebrando ahi suas orgias e bachanaes. São principalmente os machos, que reunidos em turmas de 50 a 100 ou mais individuos, condensados em compacta nuvem, invadem áquella hora a casa, para se encontrar com as femeas que ahi sabem ou suppõem existir. Quem já não terá presenceado á scena que se nos offerece, quando entramos n'um quarto escuro na hora indicada?

Uma infernal musica (1) de innumeros carapanãs fere o nosso ouvido, ao mesmo tempo que um ou outro a todo o momento vem esbarrar contra o nosso rosto, com revoltante cynismo e palpavel provocação. Fazendo luz percebemos ao redor de um fóco luminoso, dançar e fazer freneticas cabriolas a impia multidão: são duas nuvens, cada qual composta de individuos de um sexo sómente, que esvoaçando e descrevendo caprichosas evoluções, executam, mediante o som produzido pelas vibrações das azas e halteras, uma orchestra ou choro recitativo, regida pela batuta de Eros.

Quem se der ao trabalho, poderá convencer-se depressa, que ha dous sons, um mais alto e outro mais baixo: o primeiro é produzido pelos machos (2), o segundo pelas femeas. Com mais alguma pratica, chega-se igualmente ao resultado, que ha differenças perfeitamente perceptiveis no timbre do som produzido pelas diversas especies, como as ha entre os dous sexos de uma mesma especie. O canto do Culex fatigans é differente do da Stegomyia fasciata, o d'esta outra diverge do Taeniorlynnchus que por sua vez não é igual ao do Anopheles. Sinto não ser sufficientemente versado em theoria de musica, para poder definir de mais perto o caracter physico-acustico do canto de cada uma das quatro especies; estou convencido de que o som de cada uma tem um numero certo das suas vibraç̃es, que poderá ser determinado e medido por meios scientificos rigorosamente exactos.

Cantam, porque assim se fazem sentir e reconhecer a alguma distancia os dous sexos. (3) Nada mais destituido de ceremonias do que a reunião sexual: uma femeal

(1) Falta pouco para perfazer 2.000 annos jả, descle que o naturalista romano l'linius levantou a questâo na sua «llistoria Naturalis» Lib, 2* \&ubi vero fruculentam illam et fortione maxumam vocem ingeneravit culici? 0 que, livremente traduziclo seıia: a Quem é que dotou o mosquito de tão medonha voz, muito mais forte do que deveria ser em proporção ao tamanho do corpo?»

(2) Nào cantam tambem os machos entre as cigarras, os grillos, os gafanhotos, etc.?

sentidos.

(3) Us orgràos de visão não sâo lá muito excellentes nos Culiciles e em toclo o caso inferiores aos dos outros 
qualquer desliga-se subitamente das suas companheiras e approxima-se da nurem dos machos em dança. Immediatamente é segurada por um macho e, ligados, o par affasta-se da indiscreta multidão para um canto. Não é raro esquecer-se este da mais elementar prudencia: tontos esbarram contra tudo é são capazes de rolar pelo chão.

Tambem observei casos, onde uma femea cahia segurada por dous machos ao mesmo tempo, dando-se o espectaculo de um formidavel rôlo, - indicio do frenesi sexual que reina em taes bachanaes. (1)

Parece que a copula sexual tem o effeito de acordar e estimular o instincto sanguinario das femeas, pois tanto quanto se sabe até hoje concordam todos os observadores, que são principalmente só as femeas fecundadas, que se dão ao exercicio profissional da haemaphilia (2). De facto, a femea, realisada a copula e aprovisionada com uma carga respeitavel de sperma aquella sua triplice bolsa especialmente destinada para deposito do fluido fecundador - conhecida dos anatomistas pelo nome technico de receptaculum seminis e sita á base da abertura sexual feminina-com extranha furia se atira contra qualquer mammifero maior, o homem inclusive, que esteja dentro de uma área, proporcional á sua capacidade de voar e á energia dos musculos motores das azas, extrahindo-lhes o sangue. Não uma, mas muitas vezes tive occasião de vêr como o carapanã escolhe o logar idoneo para praticar a perfuração, orientando-se previamente sobre a visinhança de um vaso sanguineo e a espessura da cutis.

Nao incommodada, levantando as pernas posteriores, esfregando-as e imprimindolhes um movimento de vae e vem, em visivel signal de satisfação, enche-se a não poder mais; poder-se-ia dizer, que qual sangue-suga repleta, fica litteralmente ebria, porque uma vez chupando, deixa-se conforme as especies, mais ou menos facilmente esmagar ou apanhar com um tubo de vidro. E é sempre assim que eu obtenho as femeas dos nossos carapanãs destinadas ás minhas investigações. Finalmente larga, como tonta, cambaleando e esbarrando contra qualquer parede, pela quantidade de sangue haurido transformada em sacco ou tubo disforme, atravez do qual transparece o rubro fluido traiçoeiramente subtrahido ao nosso corpo, - corpus delicti visivel á distancia. (3)

Movendo se, com difficuldade, pelo peso do sangue, preguiçosamente, procura o primeiro cantinho socegado nas immediações, para ahi tratar da digestão.

Esta opera-se assás depressa; observações minhas a este respeito sobre Culev fatigans principalmente autorisam-me a declarar, que dentro de 24 horas a visivel diminuição nos contornos do abdomen indica o rapido progresso, aliás comprovado pelas repetidas e amplas defecações e julgo que já nas noites seguintes a femeá estará outra

(1) Dizem os autores (Theobald pag. 65) que os machos dos Culicides, com excepção dos Anopleles não costumam frequentar as casas. "I have never seen a male $C$. pipiens or of any other European species indoors, Esta affirmaçāo nào procede para os nossos carapanās aqui no Para, onde tanto do Culex fatigans como da Stegomvia fasciata os machos em nuvens diariamente invadem as nossas casas.

Pode ser que isto sómente se de onde a invasão dos mosquitos já tomou caracter e assento endemico: bom signal em todo o caso não é.

(2) Eis ahi a resposta dada pela sciencia hodierna í pergunta levantada pelo antigo naturalista romano I'linius no final do trecho, que serviu de epigraphe ao presente trabalho.

(3) Observei com o relogrio na mão o tempo que levava uma femea de Taeniorbynclus fasciolatus, clesde o mo. mento de praticar a perforação até o de largar, repleta já de sangue. Durou seis minutos. 
vez em condições de sentir vontade para repetir a experiencia. Não ha duvida, que uma e mesma femea póde buscar e normalmente buscará mais de uma ração de sangue, picando em noites successivas e-talvez individuos diversos. (1) Ahi está justamente o ponto principal, que deve nos chamar a attenção pelo prisma do interesse sanitario, pois n'isso reside a explicação da transmissibilidade de certas molestias ao homem pelo intermedio do mosquito, como vehiculo.

Se a femea se contentasse com uma ração unica de sangue humano, extrahido de um unico individuo, a molestia forçosamente extinguir-se-hia, porque, embora o mosquito femea tivesse se infeccionado com o parasita, este morreria consequentemente á morte do mosquito, pois não é hereditario para a descendencia d'aquella, quer dizer, os ovos de uma femea infeccionada não são infeccionados: A infecção é adquirida cada vez individual e pessoalmente pelo mosquito adulto. (2) Ora, precisando, por exemplo, o parasita causador da malaria o Plasmodium malariae Laveran (antigamente Laverania) sómente um periodo de 48 até 72 horas para o seu desenvolvimento (3), uma femea de Anopheles, tem com a duração de sua vida que no minimo se deverá avaliar em duas para tres semanas, evidentemente tempo folgado para chupar sangue de um malarico, infeccionando-se com a introducção de globulos de sangue affectados do Plasmodio, de permittir ao parasita amadurecer e metamorphosear-se nas glandulas salivares e de inocular o producto de scissão d'esta (o tal sporozoite de Grassi) novamente no momento, da picada, em individuo humano, antes não infeccionado.

O que eu queria deixar patente aqui, é por ora unicamente o facto, de que o cyclo normal do desenvolvimento completo do Plasmodium malariae, causador da malaria, effectua-se do mosquito (Anopheles) ao homem e do homem ao mosquito, infeccionando-se estes dous seres reciproca e alternadamente não querendo eu com isto, bem entendido, negar em absoluto uma eventual possibilidade de transmissão directa do morbo malarico do homem para o homem; porém não se dando este caso espontaneamente na natureza, e não passando além de uma experiencia artificial de laboratorio e hospital, sómente the cabe importancia theorica.

(1) Escripto isso jai alyuns dias, leio no * Journal of Tropical Medicine» 1901. 1ec. 16 um artigo de I. E. Dutton sobre a Filariase humana, onde vejo que os membros da "Liverpool Expedition. na Nigeria puderam averiguar, que o Anopheles coslalis e o A. funeslus precisam sangue pelo menos de dous em dous dias para a maturação do ovario.

(2) Koch, que a principio (ainda em 1898) tinha admittido a possibilidade eventual da hereditariedade do parasita do mosquito-mãe para os seus ovos e as suas larvas ( Ierztl. 13eobacht. in den Tropen, 13erlin 1898 pag. 366 ) já dous annos depois (1900) (Ergebnisse d. d. Malaria Expedition, Berlin 1900 pag. 5 ) entrou francamente na vereda aqui traçada.

Grassi forneceu a prova experimental (confer \& Malaria » par. 127.)

(3) E' necessario lembrar que o parasita da malaria tem dous modos de desenvolver-se, que podem guardar entre si uma certa independencia, ou completar-se e enxertar-se reciprocamente n'um unico cyclo evolutivo alargado. De. signamos uma vez o primeiro com a lettra - A.

Abranire todas as phases de metamorphose (sĩo nada menos de que 14) desde a entrada do plasmodio, com sangue humano infeccionado, pela proboscida do Anopheles, as suas migraçóes pelo interior do corpo do mosquito até a sua invasio nas glandulas salivares no mesmo mosquito prompto ji para infeccionar novamente na primeira occasiāo dada.. Realisa-se todo no corpo do Anoplueles. Chama-se technicamente o cyclo amphigonico, por ser morphologicamente caracterisado pela formação de productos sexuaes. Exiģe um periodo de 12 dias para effectuar-se.

Designamos o secrundo modo com a lettra $B$. Abrange as poucas phases da metamorphose desde a infecção de sangrue humano pela picada do Anoplseles infeccionado, - são + apenas.

Realisa-se todo no corpo do homem, no sangue. Chama-se technicamente o cyclo monogonico, por ser morpholo. uricamente caracterisado pela reproducção asexua - a esporulaçio. Não necessita senão 2 a 3 dias para effectuar-se.

Os dous modos $A$ e $B$ podem combinarese n'um cyclo evolutivo completo, alargado $\Lambda+13$, exigindo um periodo de it a 15 dias, a saber, 12 no corpo do Airopheles o 2 a 3 no corpo do homem.

Os dous modos de reproducção do parasita da malaria pódem ser convenientemente comparados com o que se da com tantos regretaes: $a$ ) reproducção sexual por sementes, $b$ ) multiplicaçào asexua por * mudas *, * estacas», filhos etc. 
Mas retomando o fio da nossa - descripção da biologia do mosquito, diremos que a femea assim fortalecida e habilitada por uma cura temporaria de alimentação especialmente sadia e roborante, qual a representa o sangue, este succo de vida fabricado por outros organismos maiores e mais fortes, sentindo-se proxima de tornar-se mãe, procura uma localidade na visinhança, que se não fôr justamente a mesma, onde ella mesmo nasceu, não esteja longe e apresente ao menos condições exteriores similares. Pousa na haste de um capim, emergindo d'agua e, vindo a hora, desce á superficie do liquido, de noite, pondo aquella quantidade de ovos, nas circumstancias que no principio deste capitulo referimos.

Questão não de todo liquidada é, se a femea, posta aquella massa de oros, é exgottada e morre, ou se retomando alimentação e sobretudo provendo-se novamente de repetidas raç̃̃es de sangue alheio, capaz de fornecer ainda ulteriores massas de ovos. Inclino-me antes para primeira eventualidade, guiando-me por aquillo que observo em femeas tidas no captiveiro: é regra geral, que ellas morrem logo algumas horas depois da postura dos ovos. Comtudo não contestarei em absoluto a possibilidade da segunda: ह assumpto de experiencias especiaes, para a qual ainda não tive o tempo.

Em todo o caso poderemos, com bastante certeza predizer, que se a segunda eventualidade de facto se póde dar na naturuza, para as ultimas posturas não é necessitada nova copula sexual, visto que a provisão de sperma contido no receptacultum seminis, é mais do que sufficiente para fecundar uma serie de posturas consecutivas de ovos.

Haja rista aos exemplos analogos com a "abelha-mestra» entre as Apides e a "içã ", na formiga saúva, onde estas "rainhas", isto é, as unicas femeas normalmente constituidas sob o ponto de vista dos requisitos sexuaes e das habilitaç̃̃es reproductivas. tambem gastam da provisão de sperma depositada no mencionado orgam, passando a sua vida, depois de curtissima lua de mel e passageira voyage noce n'uma definitiva e indiscutivel viuvez.

\section{$* *$}

Aqui é tambem o logar proprio, para communicar que as minhas observações relativas aos logares escolhidos aqui no Pará para a postura dos ovos pelo Culex fatigans por um lado e a Stegonyia fasciata por outro concordam com as que foram feitas pelos Drs. Durham e Myers (1) nos arrabaldes da cidade.

O primeiro contenta-se com qualquer poço d'agua, por mais choca e fetida que seja; depressões com agua servida, calhas de exgottos etc. tudo the serve. Assim tambem no captiveiro é aquella especie, que no laboratorio com relativa sem cerimonia se cria nos aquarios e boccaes de experiencia. Diverso já o caracter da felina Stegomyia, que é bastante caprichosa na escolha dos seus logares de criação; prefere mais a agua relativamente limpa, como costuma ser encontrada em depressões de calhas horizontaes 
de chuva nas casas, em barris, quintos, caldeirões nos quintaes, no coração das folhas ainda enroscadas das bananeiras, de bromelias etc. Tal se comporta tambem no captiveiro: não vinga a criação senão em agua isenta de outras misturas que não sejam algas'e semelhantes vegetaes cryptogam:cos proprios para a alimentação das larvas. (1)

\section{C. - Resumo do que dizem algumas notorias auctoridades acerca do papel sanitario dos mosquitos.}

Koch, em Berlim, ainda em 1898 assim se pronunciou sobre a sua opinião relátivamente á transmissão da malaria pelo Anopheles: "Em consequencia dos factos que cada vez mais se vão avolumando em favor da theoria dos mosquitos, em tempo moderno todos os investigadores da malaria, que n'este terreno alguma importancia podem fazer valer, viram-se mais e mais impellidos a acceitar esta theoria. Naturalmente é e fica provisoriamente uma theoria, que aliás tanta probabilidade tem a seu favor, que torna-se um postulado urgente resolver esta questão experimentalmente de qualquer maneira”. (2) Mas já, dous annos depois, em 1900, de volta da expedição especial da malaria, enviada pelo Governo Allemão, e chefiada por este professor, elle declarou: "A assim chamada theoria dos mosquitos deixou de ser, para nós pelo menos, uma theoria, por ter tomado feiço de um facto positivo scientificamente bem fundado». (3)

Grassi, este incansavel pesquizador italiano, disse no anno passado, no Congresso Internacional de Zoologia em Berlim, literalmente: "A malaria é uma molestia febril, que é unicamente causada pela picada do Anopheles". (4)

Howard (5) escreveu no seu utilissimo pequeno tratado sobre os Culicides dos Estados Unidos da Americá do Norte, ha dous annos: "Não é aqui o logar opportuno para discutir cabalmente o historico das recentes descobertas, que produziram a mito perfeita prova, de que os mosquitos podem transmittir e de facto transmittem o germen malarico de um paciente malarico, depositando-o no sangue de outra pessoa sã. Aquelles que se interessam n'este assumpto, seja recommendada a excellente memoria: "On the rôle of insects etc., as carriers in the spread of bacterial and parasitic deseases of man and animals" do Prof. G. Nuttall (6) e bem assim o trabalho do Dr. R. Ross (7) "Malaria and mosquitoes".

(1) Tive de abandonar o projecto, de acrescentar aqui um capitulo especial, dedicado exclusivamente á descripçio dos endo-parasitas microscopicos transmittidos ao homem pelos Culicides, conforme a actual phase da sciencia zoologico-medica. Semelhante tentativa naufrayarí necessariamente al inilio, quando não ha meio de ajudar a comprehensão do texto mediante farto cabedal illustrativo.

(2) Koch, * Aerztliche Beobacht. in den Tropen *, 1898, pas. 300.

(3) Koch, * Ergebnisse der Malaria expedition ete. $\$ 1000$, pay. 3.

(4) Grassi, « Mosquitos als Übertrïger der Filaria * Periodico * Úmschau” (Frankfurt a M.) 1901, 23 nos. tom. V. א.." 48 . pay. 947 .

(5) Notes on the Mosquitoes, Washington, 1900, par. 17.

(6) John IIopkin's Hospital Reports, Vol. VIII.

(7) Lecture at the Royal Institution of Great 13ritain, 2 March. 
E Theobald assim se exprime recentemente: "Quanto diz respeito á malaria, a theoria do Dr. Manson, na qual o principal papel cabe aos mosquitos, tem agora sido terminante e definitivamente provado o seu acerto pelo Major Ronald Ross e o Professor Grassi, e tantos outros observadores, que contribuiram com o seu quinhão para este assumpto sobremodo importante. (1)

E limitando-me a citar ainda os duos trabalhos de Rees (1900) e de Manson (1900), ambos "sobre a prova experimental da theoria dos mosquitos", refiro-me em tudo o mais á já volumosa literatura moderna, cuidadosamente compilada pelos Prof. Nuttall e Shipley no "Journal of Hygiene" Vol. I, 1, (janeiro 1901) pag. 75 e seg., Theobald “Culicides» (1901) vol. 2, cap. Bibliographia, pag. 369 e seg. e Grassi «Malaria» (1901), pag. 232 e seg.

Isto, em relação á malaria.

Agora a respeito da "filariase" vejamos o que dizem as auctoridades sobre o seu nexo com os mosquitos.

Koch já em 1898 disse na conferencia acima alludida: "Resta ainda outro palrasita do sangue, a Filaria sanguinis, que provadanevTE é transmittida pelos mosquitos". (2)

Grassi affirma: "Experimentalmente provamos que a filaria se transmitte, pela picada, do vertebrado mosquito, voltando novamente, pela picada, do insecto alo vertebrado". (3)

Pronuncia-se Theobald (1901) (4) da seguinte maneira: "O mosquito tambem age como abrigo intermediario da pequena helmintha conhecida por Filaria Bancroftii, que causa uma mortandade consideravel nas regiões tropicaes e subtropicaes. (5)

Aos Drs. Bancroft e Manson devemos a descoberta da maravilhosa historia evolutiva d'este verme nematoide. Este verme do sangue passa por transformações evolutivas nos mosquitos que ingeriram sangue humano que os contem."

E o Dr. Durham, que aqui no Pará esteve em missão scientifica, falla da filariase n'estes termos textuaes: "Esta molestia, cuja origem se prende aos mosquitos, não é raro encontrar-se no Pará ". (6)

Ora, soffrendo o cachorro de casa de um verme nematoide parasitario do sangue, proximo parente do do sangue humano, a Filaria immitis, (7) e sabendo-se que o

(1) Theobald, Culicidac, ( 1001 ), Vol, I, pag. 84.

(2) Koch, loc, cit. pas. 305. (3) Grassi loc. cit. pag. 91\%. Refere-se a um trabalho feito em collaboraça com Noe e publicado no Brilisls
Medical Journal (1900), com o titulo: * Acera da propagasio das Filarias do sangue exclusizamente pelo intermedio da picada de certos mosquitos.

(4) Loc. cit. pag. 88 .

(5) Grassi, loc. cit. pag. $9 \$_{3}$, chama a «filariase» «uma molestia terrivel, contra a qual ainda não se conhece remedio certo.

(6) Loc. cit. pag. 8 .

(7) Eu mesmo jã encontrei a Filaria immilis em cachorro no Rio de Juneiro. A auricula esquerda do coração acha-se as vezes repleta de um bólo d'estes vermes filiformes. 
parasita passa a sua phase inicial no mesmo mosquito Culex fatigans, as circumstanciadas experiencias feitas com o fim de elucidar as relações do insecto para o cachorro sob o ponto de vista do dito verme parasitario, adquiriram uma importancia capital pelo parallelismo que offerecem e as conclusões de analogia que permittem.

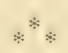

Isto em relação á filariase. Agora veremos, o que, pelo mesmo prisma, se diz da febre anarella.

Disse Grassi no. Congresso Internacional de Zoologia em Berlim (1900): «Nos ultimos mezes obteve-se tão robusta affirmação em factos experimentaes, especialmente graças ás observações de Reed, Carol e Agramontes, que se póde pretender com absoluta certeza, que e febre amarella é exclusivamente dissiminada pelos mosquitos " (1)

Theobald recentemente assim se exprime: "Pelos recentes estudos e experiencias em Cuba chegou-se a esta conclusão: O mosquito serve de vehiculo intermediario para o parasita da febre amarella, e é altamente provavel que esta molestia seja unicamente disseminada pela picada d'este insecto. "E desde então vejo pela imprensa scientifica, que é a Stegonyia fasciata, que foi demonstrada ser o hospedeiro do parasita di febre amarella. (2)

E no capitulo do seu livro, que trata da Stegomyia fasciata lê-se textualmente: "O parasita da febre amarella é disseminado por este mosquito". (3). Outrosim o Dr. Durham, da Escola de Medicina de molestias tropicaes em Liverpool, um dos medicos que aqui no Pará estiveram estudando especialmente esta molestia, escreve no.seu relatorio: "A relação dos mosquitos para com a transmissão da febre amarella não devia ser ignorada.

Por meio de experiencias directas sobre o homem, a Commissão Americana chefiada pelo Major Reed mostrou que a febre amarella póde ser transmittida por um mosquito scientificamente conhecido por Stegomyia fasciata... E' muito frequente no Pará e em Manáos nas casas, e muitas vezes é carregado por alvarengas e navios... Por certos indicios e circumstancias a Expedição no Pará chegou a pensar, que provavelmente ainda um outro mosquito bruno de casa teria igualmente sua coparticipação na transmissão da febre amarella» (4) (allude ao Culex fatigans de WViedmann.)

Koch em Berlim, tendo na sua conferencia já diversas vezes citada acima, cm 1898, chamado a attenção publica para "a febre do Texas, "grave molestia do gado no Sul dos Estados Unidos e observada por elle tambem nas novas colonias allemãs na Africa, molestia caracterisada por um parasita dos corpusculos sanguineos, chamado Pyroplasma (Pyrosoma) bigeminum e transmittido por um carrapato, (Ixodideo), Boophilus bovis e depois para a molestia "Tsé-tsé", outro flagello perigosissimo para a criação do gado na Africa oriental, por sua vez disseminada por uma mosca; passando

(1) « Umschau », loc. cit. pay. 948.

(2) Theoball, Culicidae, (1901), loc. cit. pag. og.

(3) Ibidem, pay. 293.

(+) Dr. Jurham, loc. cit. pag. 6. 
depois a tratar da malaria e outros males aparentados, exclama: "E' um facto, que recentemente chegamos a conhecer toda uma serie de diversas molestias, que devem a sua origem a certos parasitas do sangue, nos quaes a transmissão indubitavelmente tem logar por taes insectos chupadores de sangue» (1)

Poderá haver quem queira retrucar, que não se conhece ainda bem o parasita da febre amarella. Não encontro resposta melhor e mais clara do que a contida nas palavras de Grassi: "O causador da molestia é, visto que o baccillo de Sanarelli não póde mais ser considerado como tal, desconhecido ainda, n'este momento, mas o facto de que, para a transmissão da molestia, é necessario um periodo de 12 e mais dias depois de infiltrado o sangue infeccionado por parte do mosquito, isto é, um periodo igual áquelle que precisam os parasitas da malaria dentro do corpo do Anopheles, para chegar ná sua peregrinação até dentro das glandulas salivares, - o facto outrosim, que a febre amarella sómente se dissemina pelas picadas dos mosquitos, levam á supposição, que se trata de um parasita, que não deve ser muito diverso do da malaria... Certamente cada um perguntará, como é possivel, que os parasitas da febre amarella ainda não foram achados? Respondo a isto, que provavelmente grandes surpresas nos esperam. tté agora admittia-se que com os meios ordinarios de conservação e os methodos usuates de tincção os parasitas não nos poderiam escapar." (2) Estende-se Grassi, então servindo-se do exemplo das suas proprias experiencias relativas á febre do Texas, sobre a probabilidade que ha, de ter o parasita da febre amarella escapado de ser visto até agora graças talvez unicamente a certos costumes especiaes, (3) ás suas qualidades opticas ou ao seu poder refractario aos meios de tincção usuaes na microscopia.

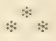

Ahi formei uma pequena polyanthéa de julgamentos emittidos por notorias auctoridades, - julgamentos todos que, com nitidez e clareza que nada deixa a desejar, caracterisam o actual estado da sciencia registrando a intervenção dos mosquitos na transmissão de uma serie de molestias graves, e das mais graves, como facto inabalavel e verdade solida.

Duvidar d'isto hoje já não é mais licito.

Facilmente eu poderia duplicar e triplicar o numero dos scientistas de vaiormedicos e zoologos que se acham á frente da brilhante phalange, que de dia em dia mais se vae avolumando, d'aquelles que possuem a necessaria intuiç̃o para romper com a rotina e comprehendendo o alcance do assumpto, são fervorosos adeptos do combate a outrance aos mosquitos. Ou poderí haver realmente quem queira ficar atraz dos negros africanos em terreno de bom senso-commum?

Pois não é sem malicia, que o celebre Prof. R. Koch em Berlim conta. (4) como

(1) Koch, loc. cit. pay. 283 sey. pag. $3(5)$ seg.

(2) Grassi, loc. cit. pag. 948 seur.

(3) A Filaria Bancrofiii por exemplo é principalmente encontrado em provas do sangue, retiradas do paciente depois do sol posto; augmenta o seu numero até meia noite, para entào tomar desenvolvimento descenciente: desde meio dia até a tarcle não se observam filarias no sanyue.

(4) Aerzt. Heob. Berlim, 1898 , pikg. 311 . 
os negros da tribu Mschamba, na montanha de Usambara, na Africa, residindo nas alturas, temem descer ás regiões baixas circumvisinhas, com medo da febre: febre tem na sua lingua o nome "mbú» $\mathrm{e}$ "mbú» significa simultaneamente na mesma lingua, mosquito; tão perfeito conhecimento do nexo causal entre mosquito e febre possuem, que designam ambas as cousas com o mesmo termo!

\section{D. - Resultados praticos que clamam por urgente applicação.}

Não ha mais duvida possivel de que devemos evitar a todo transe a picada dos mosquitos. As razões porque assim devemos fazer, subordinam-se a dous pontos de vista principaes. O primeiro é o das molestias, sendo exuberantemente demonstrado pelo que aqui adiantamos, que além da acção provadamente perniciosa d'essas especies de mosquitos na transmissão de taes molestias, ha manifesta probabilidade da existencia de outras correlações semelhantes, por ora ainda desconhecidas nos seus pormenores, onde outras especies de mosquitos, de Dipteros parentes e Arthropodos em geral serão um dia reconhecidas como directamente culpadas da propagação d'este ou d'aquelle morbo.

O segundo ponto de vista, no meu pensar não menos importante, é o do desasocego espiritual e da dôr physica. Se um respeitavel medico e scientista, o Dr. Durham, resumiu o seu juizo acerca do nosso clima e estado sanitario na phrase: «Embora em alguns respeitos o Pará não seja insalubre, o clima é excessivamente enervante, especialmente com a precisão de manter tensa a actividade mental" (1), nós no Museu para quem em alto gráo quadra o caso ahi indicado, e que, podemos dizel-o, conhecemos o clima do Pará por estudos que nos centros scientificos são taxados como os melhores e os mais aprofundados que têm sido feitos até hoje, nós não hesitamos nem um momento em declarar que, se o alludido estado de cousas existe de facto, peiorou a situação sensivelmente dentro dos ultimos trez ou quatro annos e que a culpa principal reside, ao nosso ver, na espantosa multiplicação do carapana de perna rajada, da Stegomyia fasciata! E' um horror!

E' simplesmente incrivel a tortura que a gente soffre physica e pychicamente, desde o nascer do sol até o occaso, por esta furia sanguinaria. Como se não bastasse já a anemia, este fatal patrimonio das regiōes intertropicaes, junta-se-lhe a neurasthenia, resultado em grande parte da implacavel luta pela existencia com a sua crescente acrimonia fomentada e augmentada ainda pelo desespero forçosamente sentido por quem bem queria trabalhar e não póde, devido a este flagello. Quanta energia não é matada no embryão, - quanta iniciativa não é vilmente assassinada de costas por esta viperina creatura, que incessantemente trabalha pelo descredito do Pará! Fustiga os sãos-martyrisa os doentes: qual é o pae que, vendo prostrado um ente querido por traiçoeira molestia, não sentiria a tentição de acompanhar Gœthe no seu pensamento, quando tem 
que testemunhar com os seus proprios olhos, como esta creatura infame, desalmada, de mosquito nem respeita o corpo soffredor?

Apontada assim mais uma vez a necessidade indiscutivel de abrirmos abertamente campanha contra os carapanas, approximamo-nos da tarefa de estudar summariamente os Meios de combate.

Tratando-se aqui por ora sómente dos meios tendentes a combater os mosquitos e a acção directa dos mesmos, e, apenas indirectamente, as molestias por elles causadas, obedecem as diversas categorias ao seguinte agrupamento natural:

1) installações que têm por fim affastar e impedir o mosquito do contacto com o corpo humano (mosquiteiros, installações domesticas systema Grassi etc.);

2) matança dos mosquitos adultos nas casas;

3) matança das larvas nos seus logares de creação (tratamento com kerosene, methodo Howard); exequivel;

4) diminuição ou extincção d'estes logares de criação onde isso fôr praticamente

5) saneamento em maior escala, escoamento dos brejos, - drenagem-deseccamento do solo com plantaç̃̃es apropriadas (Eucalyptus etc.)

Logo se vê que a primeira categoria comprehende medidas de mera defensiva ; as quatro outras porém revestem o caracter de declarada offensiva. Tambem comprehende-se simultaneamente, que a acção relativa ás quatro primeiras é perfeitamente accessivel á iniciativa particular, ao passo que a quinta, por motivos faceis de adivinhar, ficará principalmente dentro da orbita da acção official.

Passemos ligeiramente em revista um a um os pontos acima mencionados.

A pratica de usar mosquiteiros, para impedir os mosquitos de nos picar, é não sómente muito antiga, como tambem generalisada nos diversos paizes perseguidos pelo flagello dos Culicides. Sabemos já pela relação de Herodoto, que escrevia ha perto de cinco seculos antes de Christo, que os antigos Egypcios usavam de um «konopeion", instrumento que, pela descripção dada do seu fim, não era outra cousa, senão uma especie de mosquiteiro. Aqui no valle amazonico é assís conhecido e divulgado, felizmente, o uso do mosquiteiro. Todavia seria para desejar que o uso se fôsse generalisando ainda; bastante usado, sobretudo aqui na cidade, seria isto tanto de interesse individual como da collectividade. Ainda ha gente que reside em quarteirões d'esta cidade assás perseguidos pelos carapanãs e que não usa mosquiteiro.

Quando se trata de uma pessoa de reconhecida saúde, nada mais ha a objectar senão que constitue uma imprudencia e que a situação sanitaria poderá mudar um dia, invertendo-se; além d'isso nem se comprehende mesmo, como póde haver quem prefira deixar-se picar noite por noite, a romper com um costume rotineiro, que acarreta perigos! Mas quando se trata de uma pessoa provadamente contaminada de molestia 
transmissivel, cutaneas e outras, não chega esta pratica a significar directamente um delicto attentatorio ao interesse publico, á collectividade?

De interesse é saber que, na Italia, foram com toda a vantagem introduzidos nas regiōes flagelladas pela malaria "zanzariere", isto é, mosquiteiros especiaes, menores, para a cabeça e para as mãos, para o pessoal que, em virtude da sua profissão, é obrigado a expôr-se ao ar livre ás picadas dos mosquitos. (1) Ao mesmo tempo foram acompanhadas de optimo successo as intelligentes medidas lá postas em pratica, de proteger as habitações do pessoal das estradas de ferro, as estaçðes, etc., adoptando um systema de applicação geral e radical de tela de arame fina nas portas, janellas, chaminés, aberturas de ventilação, etc., em summa, em toda e qualquer abertura communicando o exterior com o interior. (2) Um verdadeiro triumpho da sciencia sobre a rotina significa, por exemplo, a experiencia em grande escala executada pelo prof. Grassi na zona malarica da Estrada de Ferro de Napoles a Reggio, na baixa Italia, (Provincia de Salerno), sita entre as estações Battipaglia e Reggio, justificando plenamente o jubilo do valoroso autor contido na exclamação:

«E quando se visitar d'aqui a uns annos a minha Italia, não se encontrarão mais " tantos sertões incultos e brejos invios, onde reina o germen mortifero, mas por toda "a parte campos ferteis e povoações florescentes. A Hygiene guiada pela Zoologia, terá " realisado esta obra, que a phantasia dos povos da antiguidade inseria entre os trabalhos "de Hercules." (3)

Todas estas medidas, que em $1900 \mathrm{com}$ brilhante exito soffreram na baixa Italia a prova de fogo, foram adoptadas in nuce tambem recentemente pelos Norte-americanos em Cuba: lá na Italia contra o Anopheles-Malaria; em Cuba contra a Stegomyia-Febre amarella. E com que resultados, nos conta o supramencionado artigo na "Revue Scientifique», "la fiévre jaune et les moustiques». (4)

Não direi que tudo isto tenha logo de ser introduzido e imitado á risca, porque por ora, felizmente, não existe uma epidemia aqui na cidade, que nos obrigue a cogitar promptamente em medidas draconianas, nem o typo architectonico usual das casas aqui em Belém se presta á adopção methodica do isolamento real e efficaz mediante caixilhos com tela de arame fina.

Entretanto acho bom seguir tambem n'este terreno o conselho apostolico:

Examinae tudo e conservae o que ha de melhor! Ha positivamente bastante que aproveitar e lucrar com o conhecimento perfeito das experiencias dos medicos italianos e norte-americanos, tanto para o campo da iniciativa particular, como para a esphera da acção governamental e official.

O segundo meio concerne á matança dos mosquitos adultos intrusos nas casas. Comprehende-se facilmente que isto é, no fundo, o que o povo chama "cataplasma

(1) Grassi, *Umschau. *, (1901), pag. 946, fig. 7 ("Véu e luvas \$ contra as picadas dos Anopheles).

(2) Grassi *Malaria»1901, cap. X, pag. 216-240 (com diversas estampas).

*Umschau. \#, pag. 947.

(3) Grassi «Umschau. », 1901, pag. 948.

(4) 1902. 16 Agosto, T. 18, N. 7. 
applicada em perna de páo». Poderá apenas ser considerado como palliativo em occasiōes onde a invasão ameaça tornar-se assustadora e grandemente afflictiva, como ultimamente tem acontecido tantas vezes no bairro de Nazareth.

Serviços relativamente bons presta a incineração do pó de Pyrethrum (vulgarmente "pó da Persia»), o pollen de uma planta da familia das Compostas e de parentesco proximo da Chamomilla. (1) Mas sae caro (para um quarto de cubagem média são precisas pelo menos 25 grammas, que importam, á varejo, em 750 réis quando barato) e é de effeito mais que problematico, attenta a circumstancia de não se prestar o typo architectonico usual aqui. A fumaça pyretica d'este pó narcotiza, tonteia apenas o carapana, não o mata. (Na Italia recommendam, para o mesmo fim, como o mais efficaz a incineração de uma certa côr de anilina, amarella, conhecida com o nome technico de "Laricith").

No terceiro ponto - a matança das larvas nos seus logares de criaça-abordamos, fóra de duvida, entre os meios de immediata applicabilidade, aquelle de mais seguro e de mais efficaz effeito. Entre as diversas modalidades theoricamente possiveis tem provado como a melhor, sob o ponto de vista pratico, a applicação do kerozene impuro sobre as superficies d'agua onde os mosquitos se criam. Tirando proveito da circumstancia, acima descripta, de ter a larva do mosquito necessidade de vir tomar ar á superficie de minuto em minuto mais ou menos, compromette-se do modo o mais grave a vida d'estas larvas, despejando sobre a agua uma diminuta quantidade de kerozene (ou de oleos semelhantes) que logo em finissima pellicula se espalha sobre uma larga área, formando uma camada, e fecho impermeavel. Nem a larva consegue passar impunemente atravez esta coberta oleosa com o seu siphão respiratorio sem que logo o azeite the entupa e grude a entrada para o systema tracheano, nem as femeas, que tencionarem depositar os ovos, podem desempenhar-se d'esta tarefa sem correr perigo de atolar-se. E' experiencia assaz facil de repetir-se, que pouco kerozene é sufficiente para matar as larvas contidas n'um deposito d'agua de superficie relativamente grande.

O methodo não é novo; entretanto foi sómente em 1892 que o Prof. Howard nos Estados-Unidos insistiu nas suas grandes vantagens e recentemente o tratamento a kerozene é o remedio mais usado em grande escala nos paizes onde o combate aos mosquitos está methodicamente organisado. E' applicado na Italia, nos Estados-Unidos, nas colonias francezas, nas Indias, na Africa, na Australia, nas Antilhas.

Em Calcutta as autoridades municipaes possuem um corpo de trabalhadores especialmente instruidos para este fim, que diariamente empunhando uma vasilha com kerozene e levando ao hombro uma vara comprida com uns trapos na ponta vão pro-

(1) O melhor modo de usar o pó de Pyrethrum é o seguinte: Molha-se o pó, tal como se encontra na drogaria, com tanta agua, quanto necessaria para formar uma massa plastica. D'esta forma-se pequenos cỏnes, que se seccam
sobre uma folha de metal no forno. Seccos estão promptos para o uso; accendem-se com um phosphoro na ponta. Dous ou tres d'estes cônes serāo sufficientes em geral para impòr aos mosquitos o armisticio de algumas horas n'um quarto de dimensöes regulares. 
curar as poças d'agua estagnadas nos arredores da cidade, applicando-lhes o kerozene. Chamam-no "mosquito-brigade. »

Semelhantes corpos existem hoje tambem já nas possessões inglezas e allemans da Africa, no Sul dos Estados-Unidos e agora em Cuba.

Tambem os francezes applicam este systema nas suas colonias, tendo principiado pela do Senegal.

Sendo averiguado que por via de regra o mosquito não irradia espontaneamente do logar que lhe foi berço, além de um a dous kilometros no maximo - só isoladamente e levado accidentalmente por correnteza aerea violenta elle transporá distancia maior póde-se presumir com bastante certeza que tratando a kerozene os brejos e poças d'aguas estagnadas sitos dentro d'este perimetro, tal cidade poderá ser libertada da invasão dos mosquitos intrusos dos arredores. Para dar um exemplo: estou convencido de que nós no bairro de Nazareth não soffremos pelos carapanãs vindos do Marco da Legua e pontos de igual distancia; - os que nos atormentam virão das baixadas de ambos os lados, dos capinzaes e das muitas poças d'agua, abandonadas ao descuido, nas rocinhas immediatamente circumvisinhas.

E aqui será a occasião de externar a nossa opinião, de que a pasmosa abundancia dos mosquitos no bairro de Nazareth (1) observada durante os ultimos annos não será extranha ao estado tanto tempo lastimavel da Estrađa da Independencia entre a Igreja de Nazareth até o Largo de São Braz. Observações directas autorisam-nos a apontar por ahi como em bôa parte culpado d'esta situação. Gerações sem conta de carapanãs tiveram tempo de desenvolver-se n'aquelle lodaçal de inglorio aspecto e infausta memoria. Ora, quando pelo que acima dissemos no capitulo Biologia, por um lado, e por um simples calculo por outro lado, podemos nos convencer que a descendencia theorica de uma unica femea de Culex fatigans attinge a 160 milhros já com a quinta geração e isto no curto praso de pouco mais de 3 mezes -- perde evidentemente muito do seu mysterioso o caracter endemico da praga do carapana pelos nossos lados, para fazer logar a um sentimento de motivado scepticismo, que - sem uma prompta coalição da iniciativa particular com a acção official - a calamidade não poderá ser mais desalojada das avançadas posições de que se apossou na mais futurosa parte da nossa cidade. Que optima occasião offerece-se aqui para uma experiencia em certa escala maior, com o kerozene, nas baixadas circumvisinhas do bairro!

E que não se venha objectar-me o protexto de que tal ensaio haveria de sahir muito caro, a menos que não se invente um qualquer kerosene politico especial! E que não se allegue quaesquer difficuldades ficticias locaes e sui generis que se poderiam oppôr á applicação do methodo, pois redundaria simplesmente em testimonium paupertatis de confessar, que aqui entre nós não haveria meio de executar o mesmo que se consegue nas Indias, na Africa, nas Antilhas, n'um meio indigena social e ethnico, ao qual de certo não ha de se querer attribuir uma effectiva superioridade intellectual.

(1) Tive occasião de verificar até no Theatro da Paz, no Largo da Polvora, por diversas vezes durante espectaculos nocturnos, fartura de mosquitos dançando - tanto que uma pessoa de fóra não poderá deixar de ficar impressionada desagradavelmente. 
Venha e appareça, pois, uma vontade superior, que diga: "Mãos á obra! Fóra com os carapanãs! ”

O quarto ponto vae de braço dado com o anterior, não sendo senão o seu complemento logico. Claro é que, evitando cuidadosamente pelos quintaes e rocinhas a accumulação de vasilhas com agua estagnada e eliminando assim toda e qualquer occasião de formarem-se ás escondidas logares de criação para as larvas dos carapanãs, dando-se assim uma caça methodica, continuada e persistente, consideravelmente se contribue para o supremo alvo - a extinç̧ão dos mosquitos pela immediata visinhança. Obvio é, que semelhante tactica dará pleno resultado sómente quando seguida á risca universalmente, sem excepção, quando a convicção das vantagens communs fôr infiltrada por igual em todas as camadas sociaes e constituir-se o principio agente para o auxilio expontaneo na obra collectiva. N'este sentido benefico effeito antevejo no bom exemplo de pessoas intelligentes, que particularmente pelas suas casas adoptem a guerra racional contra os mosquitos, na propaganda dos medicos na sua clinica particular, pois elles exercem uma legitima influencia e last not least na animação que deriva da acção e iniciativa official quer na esphera administrativa municipal, quer na estadoal.

Quanto ao quinto ponto - saneamento radical da cidade e dos arredores - por obras publicas de maior vulto - não pretendo entrar aqui mais de perto no seu estudo e discussão.

Claro é que ahi reside, no fundo, a verdadeira solução do magno problema e que a attenção administrativa não poderá deixar de ter sempre em vista preparar a situação, para que a questão possa passar da phase dos projectos para a das realidades. Mas tambem salta aos olhos por outro lado, que seus factores, o technico e o financeiro fazem com que este meio, idealmente o melhor, não passe de um "saque a praso longo ».

De passagem eu queria ainda dizer, que a pretendida acção protectora da arvore Eucalyptus, de origem australiana, contra a praga dos mosquitos, não passa, conforme experiencias norte-americas communicadas pelo prof. Howard (1) e como aliás era de prever - de uma conclusão erronea, pois esta acção, em vez de ser directa, como se pretendia, é apenas indirecta e limita-se a diminuir os logares apropriados para o desenvolvimento das larvas pelo enxugamento do solo.

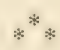

Depois de ter passado em rapida revista os meios de combate directos contra os mosquitos, resta-nos dizer alguma cousa acerca do modo como nós imaginamos que deveria ser encaminhada e organisada a propaganda contra as molestias por elles transmittidas. Condensarei as minhas idéas em algumas theses principaes, que serão commentadas, quando d'isso haja mistér.

(1) Howard, Notes etc., pag. 62. 
1.0 Julgo de grande importancia e alcance esclarecer o publico, divulgando, pelos meios apropriados; conhecimentos sobre a accão dos mosquitos e a sua correlaço com as diversas molestias.

Ha vantagem n'isto não sómente em relação á cidade de Belem, pelo prisma da febre amarella, da filariase e outras, como tambem em relação ao interior, pelo prisma da malaria. Um inimigo que se conhece e que se enxerga não é nem de longe tão perigoso, como um que é invisivel, immaterial como um phantasma. Estou firmemente convencido, que o publico nas regiões perseguidas por sezões, orientado sobre o nexo causal entre a malaria e o Anopheles, e conhecedor das soberanas armas que se possue, tanto n'uma intelligente prophylaxia, como n'uma adequada e criteriosa therapia com a quinina, (1) com mais calma poderá enfrentar as investidas e tentativas d'este morbo polymorpho. E creio que a residencia em logares e regióes de notoria má reputação sanitaria, como por exemplo grande parte do littoral đa Guyana (Amapá, Calçoene, Cunany, Cassiporé, Oyapock) muito perderá do terror que çar-se-á maior estabilidade. Penso que o Governo, seguindo para o seu pessoal administrativo lá estacionado, o exemplo dos medicos italianos na Provincia de Salerno, e dos norte-americanos na ilha de Cuba, se por um lado gastaria por ora, talvez, um tanto mais na primeira installação, bons resultados obteria por outro, revertendo em economia no futuro. (2)

2. Opino que a aç̧o official com vantagem entraria a campo desde já, em forma branda, isto é, dando o bom exemplo, incitando a iniciativa particular a seguil-o, e principiando por casa:

a) cogitando da organisação de "mosquito - brigadas" sobre o modelo em uso nos outros paizes;

b) reformando eadoptando os hospitaes ás exigencias do actual estado da sciencia em relação aos mosquitos;

c) emprestando gratuitamente aos necessitados mosquiteiros em casos de febre amarella e tratamento em domicilio;

d) examinando, sem animo preconcebido, seriamente a questão, se ultimamente não foram, dentro da cidade e seus arredores immediatos, talvez projectadas e executadas obras de ajardinamento etc, que pelo emprego de consideraveis superficies d'agua não sufficiententemente movimentada, não poderiam constituir-se em outros tantos logares de criação de mosquitos.

Os logradouros publicos, tanques ornamentaes, lagos, etc., que em tempos normaes não contribuiriam de modo sensivel, para augmentar o flagello, tornam-se entretanto um factor digno de reflexão n'um periodo de invasão e inundação de carapanãs, como o temos actualmente.

(1) O fito em primeira linha a alcançar n'esta conjunctura deverá ser a immunisação artificial da população. U esperar pela outra, immunisaçăo natural e expontanea, este caminho por via de regra sahirá caro e nāo será conquistado senàn á custa de muitas vidas humanas e depois de muitas geraçסes.

(2) Grassi ( Malaria pag. 213) estabelece o principio, hygrienico - como juridicamente interessante, da obrigacito do Estado, de cuidar do tratamento obrigatorio de todos os malaricos indirectamente. Ora, tendo o Plasmodium malariae, o parasita das sezóes, dous hospedes, - o Anopheles e o homem-do mesmo principio logicamente derivaria tambem a obrigação official do Estado para a lucta da extincção dos mesmos carapanàs. 
Não sendó dada a possibilidade de movimentar devidamente a agua, conviria povoar taes depositos d'agua com um forte contingente de peixinhos vivos, de agua doce, prestando-se evidentemente para semelhante fim os nossos jejús pequenos, as diversas especies de acarás, os sarapós e os tamboatás, do comprimento médio de um dedo. São inimigos natos dos carapanãs e das suas larvas, devorando d'ellas quantidades verdadeiramente assombrosas.

3. Náo posso libertar-me da idéa de que o hospital dos leprosos no Tocunduba está mal collocado, sob o ponto de vista hygienico moderno e que conviria a sua remoça para local mais afastado.

Não tenciono entrar em pormenores sobre este assumpto, porque isto nos levaria longe. Desejo simplesmente ver archivado aqui que uma qualquer situação, em relação ao hospital para com a cidade, entre $\mathrm{N}$ E e S E, quadrante varrido pelos ventos dominantes diarios aqui em Belem, e em distancia que não seja bastante superior a 2 kilometros, não corresponde aos requisitos hodiernos de um hospital de isolamento para doença transmissivel pelos mosquitos.

Aproveito comtudo a occasião para dizer que não faltam autorisadas vozes no mundo medico, que entre as molestias transmissiveis especialisam nominalmente ainda, além das já mencionadas, o anthrax, a elephantiasis e outras affecções do systema lymphatico, como morbus para os quaes um nexo causal com os mosquitos e insectos parentes é igualmente provavel. (1) poucos dias, ao correr da penna sob o impulso de intima convicção minha, que era tempo de eu intervir, na qualidade de zoologo e chefe de um estabelecimento scientifico, nesta questão, que se me afigura de gravidade. A classe medica aqui em Belém tinha o direito de esperar que fosse primeiramente elucidada a posição systematica dos mosquitos predominantes n'esta cidade, antes de tomar posição no assumpto, e não ha duvida que esta tarefa, aqui como em outra parte, cabia antes de tudo á sciencia natural descriptiva. Ora, feito este trabalho no nosso Museu, determinados não sómente os Culicides nossos, como estudados tambem sob o ponto de vista biologico, averiguada agora de modo absolutamente seguro a identidade dos nossos principaes carapanas paraenses, com aquellas especies que alhures justamente tristissima reputacão possuem como transmissores de algumas das mais graves molestias tropicaes, são dadas para a medicina e a hygiene as bases de operação ulterior. Senti a responsabilidade que me cabia como naturalista, n'este problema attinente ao bem-estar publico, e julgo que me desobriguei d'ella lealmente.

Caveant consules!

Dixi.

Belem do Pará, fins de setembro de 1902.

(1) Que toda a prophylaxia contra certos outros graves flagellos da humanidade taes como tulerculose, cholera, peste asiatica parte do mesmo ponto de vista, é assás sabido. 


\section{Resumo provisorio dos resultados da campanha de experiencias executadas em 1903, espe- cialmente em relação ás especies Stegomyia fasciata e Culex fatigans sob o ponto de vista sanitario.}

13ht ist ein zanz besond rer Saft

Goethe, - Esust *

\section{NOTA INTRODUCTORIA}

Não emprehendi os estudos, dos quaes por ora sómente me é possivel dar um resumo preliminar, "pour me tailler un rôle», como na lingua franceza com graça se diz, na tão debatida questão dos mośquitos no seu papel como transmissores de molestia. Approximei-me do assumpto em fins de 1901 - como mero naturalista e zoologista, antes com o fervoroso desejo de aprender no contacto com os mestres na materia, do que com a esperança de jámais poder ensinar outros.

Se eu, querendo a principio ser nada mais que espectador, fui empurrado para o meio, no campo da acção, a responsabilidade cabe a circumstancias alheias á minha vontade. Desejando seriamente instruir-me, atirei-me ao estudo dos mais afamados livros que na especialidade tinham sido publicados, principalmente com o fito de orientar-me bem sobre a systematica e a biologia dos Mosquitos brazileiros. Caía n'este periodo exactamente a publicação da monumental llonographia dos Calicideos do Dr. T. V. Theobald, do Museu Britannico de Londres, obra esta que veio assim a ser para mim, n'este empenho, o que se chama "ouro sobre azul". Nas, por mais que me satisfizesse a perfeição que encontrei n'este admiravel trabalho, relativamente á systematica dos nossos Mosquitos, falhava por via de regra a resposta para uma qualquer pergunta que eu comm'go formulasse acerca dos pormenores biolog.cos. Examinando a dita obra de mais perto, debaixo d'este ponto de vista, fiquei impressionado do pouco que constava dos costumes e do modo de vida dos nossos mais vulgares Mosquitos. Vi e convenci-me de que, mesmo sobre alguns dos problemas mais elementares, reinava escuridão quasi completa e sensivel incerteza.

Voltei a minha attenção para a litteratura indigena, desconfiando que talvez os representantes da sciencia medica se achassem em uma phase de saber mais adiantada sobre os Mosquitos nacionaes do que a minha. O calor que se notava na imprensa diaria 
e profissional, na discussão de assumptos atinentes a este dominio, pelo menos podia justificar tal espectatixa minha. Vi Gregos e Troyanos, Blancos e Colorados, Convictos e Scepticos, Adeptos e Refractarios, Moderados e Radicaes extremados entrarem na discussão com tanta paixão, que se podia julgar que ambos estivessem desde muito de posse plena das premissas biologicas, versando a controversia talvez unicamente sobre o modo de interpretar em sua applicação á therapeutica, prophylaxia e hygiene. Qual não foi a minha surpreza e decepção quando, olhando de mais perto, percebi que n'esta arena as armas principáes em uso de cá e de lá consistiam em trechos emprestados e adrede apparelhados de autores extrangeiros e trabalhos de outros paizes, e que rarissimos cram os vestigios de investigação propria, de pesquiza independente, de trabalho mental original, trazendo o cunho e feição do experimento e do laboratorio, em vez da toga da dialectica salernitana?

Assim eu, não encontrando, nem por um lado nem por outro, informação satisfactoria nem sequer sobre os elementos e os contornos principaes da historia natural dos Culicideos brazilicos, e compenetrado de que sem o conhecimento d'estes não podia haver possibilidade para uma fructifera discussão do papel sanitario; reconhecendo emfim, em uma palavra, que para um assumpto ferindo tão genuinamente os mais altos interesses vities do paiz deve existir um solido substrato e pedestal com materiaes locaes, resolvi metter mãos á obra. Si já Grassi no caso do Anopheles-Malaria pronunciou que o terreno pertencia ao zoologista, preparado em assumptos de medicina e ao medico, familiar com assumptos de zoologia, a situação é a mesmissima no caso da Stegomyia - Febre anarella, no do Calex fatigans - Filariase.

O medico por si só não resolverá a questão: terá forçosamente que recorrer ao naturalista, para d'elle obter o substrato necessario de conhecimentos de historia natural. E era preciso que viesse uma vez um embaraço d'estes devéras penoso e afflictivo, para abrir os olhos aos que pensam e seriamente se empenham no levantamento intellectual do paiz, e para mostrar-lhes a insufficiencia actual do ensino de sciencias naturaes no programma dos estabelecimentos superiores e incutir-lhes a convicção de que, a menos que não se queira resignar-se beatamente a ficar atraz no certamen e tendencia progressista internacional, urge prestar mais attenção e respeito íquellas sciencias que os povos mais praticos do mundo cultivam com zelo ostentativo, trazendo-as na palma da mão!

Foi d'est'arte um verdadeiro dever moral que senti de esforçar-me, no que dependesse das minhas forças e meios pessoaes, para poupar ao Brazil a vergonhosa exprobração de que aqui se discutia hygiene e prophylaxia relacionadas com os mosquitos indigenas, sem que houresse um unico trabalho sequer que pudesse ser considerado como podendo servir de base e fundamento na parte biologica, nos elementos de historia natural.

Durante os annos de 1902 e 1903 estiveram estas pesquizas no primeiro plano da minha actividade scientifica; dediquei-lhes o maior quinhão de tempo e attenção. Submetti aos meus estudos a quasi totalidade das especies de Mosquitos encontrados no Pará e no baixo Amazonas, e não são poucas. Entraram n'esta esphera representantes dos generos Stegomyia - Culex - Anopheles - Taeniorhynchus - Panoplites Trichoprosopon - Ianthinosoma - Sabethes - Megarhinus - Limatus, conseguindo eu quasi em toda a parte esclarecer pontos ainda escuros na historia da sua vida, con- 
tribuir com materiaes antes ignorados e ainda ineditos. Tive sempre o inestimavel e valioso auxilio do Sr. Dr. Theobald, em Londres, o que equivale a uma garantia, sobretudo no dominio das questões systematicas e da identificação exacta. (1)

A publicação detalhada, em extenso, das minhas investigações durante a recente campanha, exige mais tempo e mais avultadas providencias, mórmente em relação ao lado illustrativo, do que dispuz até agora. Todavia tenciono publicar dentro de prazo não muito longo, um trabalho mais comprehensivo, acompanhado de estampas coloridas, do habitus dos principaes mosquitos da fauna paraense. Attento ao cuidado que tive de escolher especies de larga distribuição sobre o littoral do Brazil tropical, nutro viva esperança de que o referido trabalho será bemvindo ao mundo medico indigena todo. As estampas são feitas de mosquitos vivos e frescos em escala tamanha e com tão minuciosa exactidão que poderão servir de padrão em circulos scientificos como em circulos de leigos instruidos.

O que aqui, nas presentes linhas dou, é apenas um resumo muito condensado das minhas experiencias e resultados sobre certos pontos, assaz controvertidos, da vida dos nossos mosquitos domesticos mais communs e mais importantes - a diurna Stegomyia fasciata e o nocturno Culex fatigans. São aquelles pontos a que assiste um interesse de todo especial pelo lado pratico e sanitario.

(Confira-se o questionario detalhado, que puz como guia orientadora, no cabeçalho das experiencias).

São em primeira linha o problema do papel do sangue haurido, na economia interna do mosquito-femea, em relação com a copula sexual por um lado, e com o processo da postura dos ovos por outro lado. Abrangem estas experiencias mais de 220 individuos adultos de ambos os sexos, de Stegonyia fasciata e além de 260 individuos de Culex fatigans; (não entrando em conta ovos e larvas de ambas estas especies, que andam por milhares).

Esbocei este resumo em consequencia de pedidos insistentes de amigos no mundo medico brazileiro, ornamentos da sciencia, residentes no sul do paiz.

Algumas palavras acerca da instrumentagem, por mim utilisada nas experiencias que seguem. Havendo conveniencia em poder executar o rigoroso isolamento simultaneo de muitos individuos ou de muitos casaes, quer de uma quer de outra especie, era mistér architectar um typo de gaiola apropriado leve, manuseavel e barata ao mesmo tempo. Bem depressa achei um modelo que preenchia satisfactoriamente todos estes requisitos e que conservei até hoje. E' uma caixinha leve, de madeira de cedro, de fórma prismatica, de $30^{\mathrm{cm}}$ de comprimento, sobre $13^{\mathrm{cm}}$ de largura e $20^{\mathrm{cm}}$ de altura. Fun-

(1) Que a respectiva correspondencia nào tem deixado de trazer vantarens para o conhecimento dos mosquitos d'aqui, resalta Josro para quem compulsa o recente volume III supplementar da grande Monographia do Dr. Theobald, publicado durante o anno de 1903. 
do, costas, tecto e metade superior da frente, são de téla de arame de malha fina; a parte inferior do lado frontal é formada por uma porta de um vidro, corrediça no sentido lateral. Alimento e agua são introduzidos facilmente em bacias de vidro rasas de dimensões adequadas. Sendo estas gaiolas assaz transparentes, e de dimensões diminutas, facil é não só introduzir mosquitos frescamente apanhados, como retirar um ou outro individuo; emfim, fiscalisar todos os acontecimentos que se effectuam lá dentro. Com lettreiros de iniciaes mutaveis, impressas com chapas sobre pedacinhos de cartão branco, significando $\mathrm{S}=$ Stegomyia, $\mathrm{C} . \mathrm{F} .=$ Culex fatigans, a. = apanhados em liberdade, $\mathrm{c} .=$ criados no captiveiro, $\mathrm{m} .=\mathrm{mel}, \mathrm{s} .=$ sangue, e os signaes sexuaes $(\sigma)$ macho, \& femea), consigo um codigo correspondendo a todas as necessidades, no sentido de facilitar uma rapida synopse e orientação sobre o conteúdo e o systemá da experiencia. Outrosim, recebe cada caixa, preso por um percevejo a um dos cantos, uma lingucta de papel onde se lançam as annotações diarias. Disponho de umas 40 e tantas d'estas gaiolas, todas constantemente em uso simultaneo.

Tem este modelo da nossa invenção, em comparação com a caixa recentemente figurada e proposta pelos Drs. Sergent, do. Instituto Pasteur em Paris, no seu utilissimo livrinho "Les Moustiques» (Paris, 1903 ), a vantagem de ser muito mais manusearel, mais simples e mais barato, com economia de espaço, de tempo e de dinhe:ro. Um marcineiro de alguma habilidade, apromptará facilmente meia duzia das minhas n'um meio dia c o seu custo total importa n'uma bagatella.

A criação dos ovos é feita em bacias rasas de vidro até sahirem as novas larvas que, excepto Stegomyia fasciata e Culex fatigans, são ás vezes creaturas singularmente delicadas e exigem não pequena somma de attenção. Costumo reúnir estas bacias ás 2 e $3 \mathrm{~cm}$ gaiolas iguaes em dimensões ás outras, mas com téla de malhĭ mais larga.

Para a criação das larvas utiliso um grande numero de boccaes de vidro de variavel altura, cuja bocca fica tapada com um pedaço quadrangular de talagarça, amarrando-se esta por baixo da saliencia peripherica com um barbante. No centro, corto com a tezoura uma abertura rolhada por sua vez com um tampão de algodão: em summa, n'este particular, é o systema já proposto e aconselhado por Grassi. - (1)

Que o mel constitue um meio de alimentação excellente, descobri tão independente como casualmente.

Tendo ficado um dia, por accaso, em cima da mesa de jantar, um vidro quasi vasio que contivera antes mel de abelha européa, trazido por nós mesmo da Serra dos Orgãos (Rio de Janeiro), fiquei impressionado pela multidão de mosquitos que, de dia mesmo, se tinham introduzido em busca da dôce substancia, que por sua vez é um producto manufacturado no estomago de um insecto. Eram umas 40 e tantas Stegoymias e Culex, de ambos os sexos. Immediatamente resolvi aproveitar-me d'esta observação e devo dizer que com optimo' resultado, tanto que posso recommendar este methodo calorosamente a quem quizer fazer experiencias no sentido das por nós realisadas. 


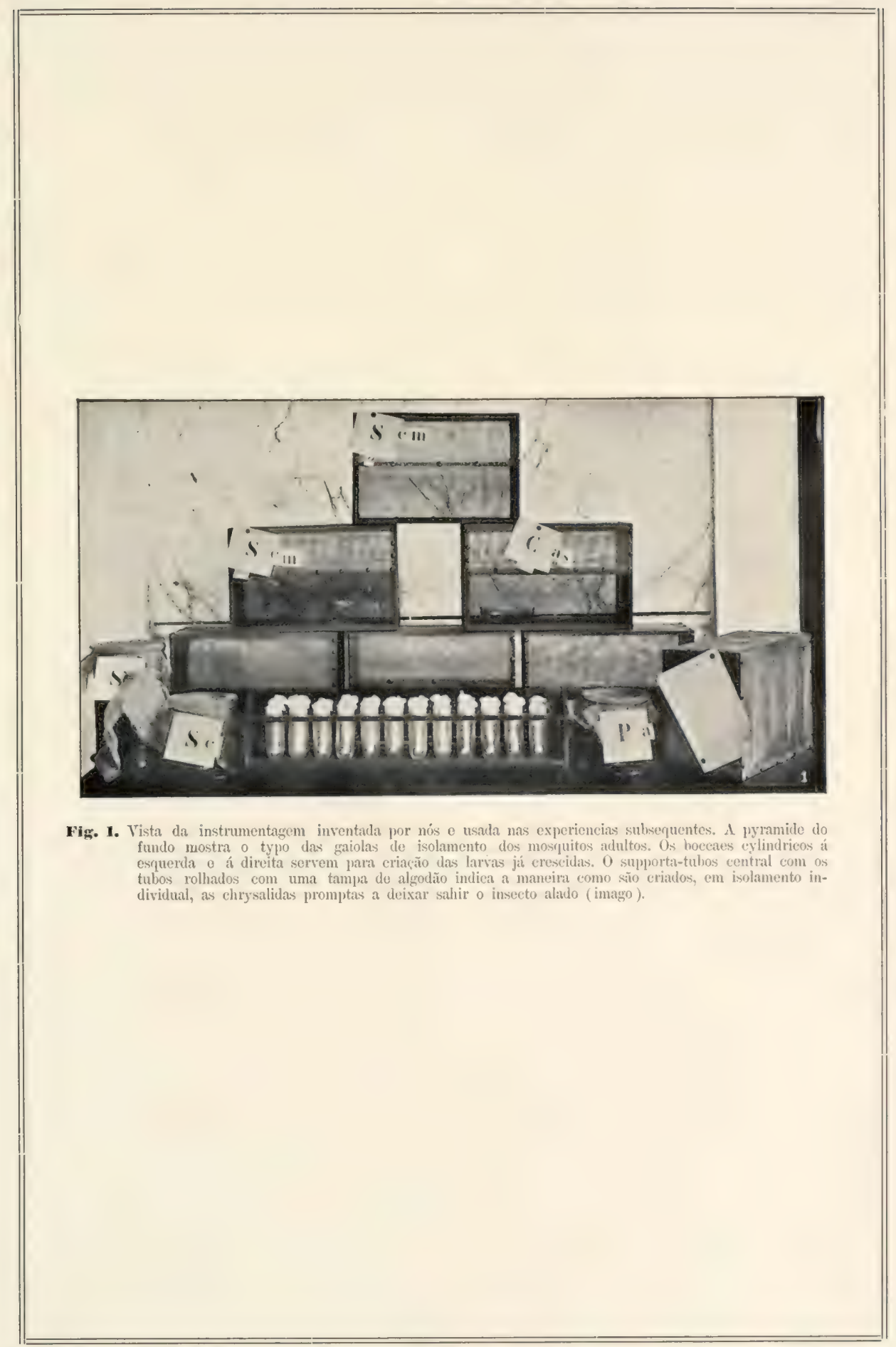



Ultimamente vi, por um artigo n'uma revista medica, (1) que o Dr. Lutz, em São Paulo - entre os principaes fomentadores de estudos originaes sobre a vida dos mosquitos no Brazil, o mais antigo - tambem preconisa o uso do mel para o mesmo fim, e não duvido que este observador se tivesse familiarisado com elle da mesma fórma e pelas mesmas razões que eu. (2)

Concluo declarando que não me abalarei a tomar em consideração contestações e censuras dos meus resultados, seño dos contendores que provem ter feito estudos igualmente conscienciosos e comprehensivos.

Res non verba. Quem tiver animo de combate, que o faça de viseira erguida e mostrando a lealdade das suas armas. Vivendo eu na firme convicção de que, d'estes problemas, mais do que de quaesquer outros, depende a solução directa da exposição fiel e exacta do methodo seguido e das circumstancias exteriores, debaixo das quaes as experiencias foram realisadas, e tendo eu dado o exemplo nas paginas que seguem, faço para qualquer outro condição essencial de identico procedimento.

Por ultimo direi que, a quem só superficialmente conhece alguma cousa da moderna litteratura scientifica poderiam apparecer todos ou a maior parte dos meus resultados como carecendo de novidade e de merecimento, por constituirem as leis por mim formuladas a necessaria supposição e premissa para toda a recente doutrina acerca dos mosquitos.

Ainda quanto a isto, a minha consciencia me tranquilisa; se bem que estas leis estivessem, por assim dizer, pairando no ar, aquelles que conhecem a materia a fundo, perfeitamente sabem que faltava até hoje a prova experimental e material, que esta falta constituia uma lacuna e brecha assar sensivel e incommodativa no edificio do actual saber. Estes sim, saberão avaliar do perto o merecimento inherente a estas tão conscienciosas quão comprehensivas labutações e o applauso d'estes será para mim a melhor recompensa para toda esta penosa cruzada de experiencias e contra-experiencias.

Pará, 9 de janeiro de 1904.

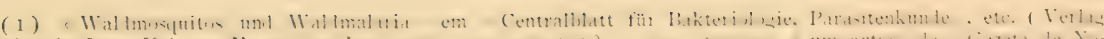

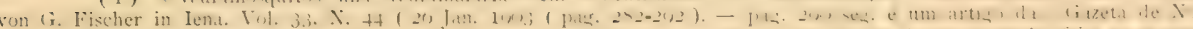

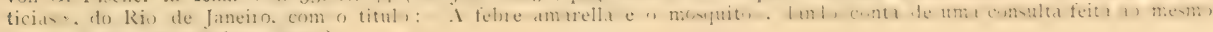
1)r. . L Lutz (2) ontubre, 1(x)3)

(2) Bancroft recommendou calorosimente o empreyo de tamaras seccas penduradas na yajola, para substituir as fatias de banana, antes em uso n'estas experiencias. Concordam Nuttall e shipley, loc, cit, pay. 70. 


\section{QUESTIONARIO}

I

\section{Influencia da alimentação sobre a duração da vida no captiveiro}

a) a alimentação com mel, liquidos assucarados, sumos de fructas, etc., prolonga ou encurta a vida?

I) quaes os effeitos sobre o sexo feminino?

2) quaes os effeitos sobre o sexo masculino?

b) a alimentação com sangue, prolonga ou encurta?

I) effeitos sobre o sexo masculino?

2) effeitos sobre o sexo feminino?

I I

Influencia da alimentação sobre a fecundidade das femeas de Stegomyia fasciata, nascidas em liberdade e postas no captiveiro

a) a alimentação com sangue, favorece e accelera a postura dos ovos?

b) ha um sangue animal

$$
\begin{aligned}
& \left.b_{1}\right) \text { preferido? } \\
& b_{2} \text { ) optimo? }
\end{aligned}
$$

c) a alimentação com mel tem effeito

$\left.c_{1}\right)$ retardativo e interruptor?

ou $c_{2}$ ) paralysante e destructivo?

d) qual o effeito de outra alimentação?

$d_{1}$ ) animal (extracto de carne, sumo de carne, etc.)?

$d_{2}$ ) vegetal ( sumo de fructas, etc.)?

Influencia da copula sexual sobre a haemaphilia e a fertilidade das femeas nascidas no captiveiro

a) femeas Nio fecundadas chupam $\left\{\begin{array}{l}\text { a) sangue? } \\ \text { b) mel: }\end{array}\right.$

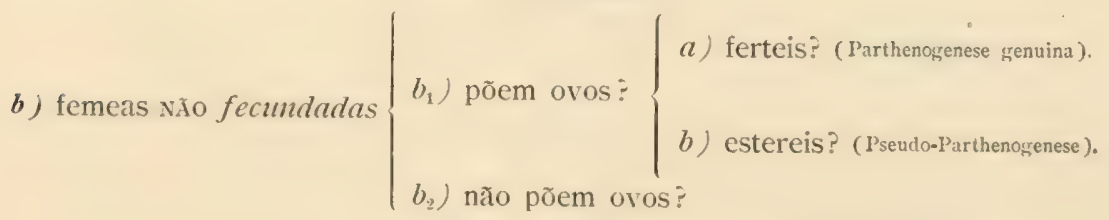

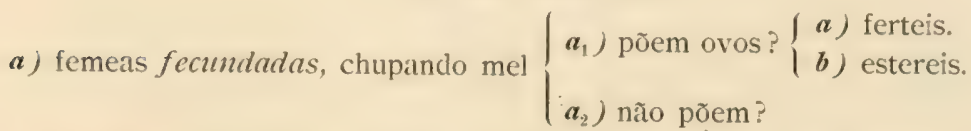

b) femeas fecundadas, chupando sangue $\left\{\right.$ põem ovos? $\left\{\begin{array}{l}a) \text { ferteis. } \\ b \text { ) estereis. }\end{array}\right.$ 


\section{EXPERIENCIAS}

\section{Stegomyia fasciata}

\section{EXPERIENCIA 1.}

No dia 1 de agosto de 1903, de manhan, foram postas em 3 gaiolas, (das de nossa invenção para o fim especial da observação continua dos mosquitos no captiveiro) ao todo 16 femeas de Stegomyia fasciata, sadias e robustas, apanhadas em liberdade com o borboleteiro (Museu e dependencias), ao accaso, isto é, sem que ellas trahissem pelo seu aspecto exterior, haverem chupado sangue humano ou de qualquer animal nas horas immediatamente aanteriores, embora admittamos sem hesitar tal possibilidade, bem como a probabilidade de terem sido previamente fecundadas todas ellas.

Na gaiola $C$ entraram 2 femeas; na gaiola $A, 5$; na gaiola $B, 9$ femeas. Tratamento com mel de abelha e com agua (exclusiramente, sempre e em todos os casos, onde não ha expressa indicação contraria), offerecida cada uma destas cousas em pequeno pratinho de vidro.

\section{Caixa C. 2 femeas.}

Tendo as duas femeas sido alimentadas exclusivamente com mel de abelha e agua desde o dia 1 até o dia 23 de agosto (23 dias), muclou-se repentinamente de regimen, dando-lhes sangue no mesmo dia 23 (deixando-as picar cobayals encostadas com a mão pelo lado exterior da tela. (1) Tomaram logo o sangue offerecido em apparente boa ração cada uma.

Não tendo sido postos ovos durante os dias 1 até 23 de agosto (alimentacão a mel) agora appareceram logo duas posturas: I) em 28 de agosto (36 ovos; intervallo, 5 dias) e II) em 30 de agosto ( 35 ovos; intervallo, 7 dias). Observação das primeiras larvas no dia 5 de setembro (intervallo de 6 dias); os ovos eram ferteis. Isoladas as posturas e postas nos boccaes especiaes de criação, continuou-se a administrar sangue de cobaya da seguinte fórma:

dia 30 de agosto (ambas as femeas tomaram uma ração cada uma);

dia 1 de setembro, idem, idem, idem:

dia 4 de setembro, idem, idem, idem.

(1) Como se vê por uma multidão de experiencias aqui enumeradas, as femeas de Stegomyia acceitam sangrue o prestam-se a picar com satisfactoria facilidade, não só as primitivamente apanharlas em liberdade e depois postas em graiola, como tambem as femeas criadas no captiveiro. E se não me engano, outros observadores em diversos pontos do Brazil, tambem nào reconheceram na Stegomyia, em captiveiro, um mosquito recalcitrante o estouvado. Surprehendeu-me deréras tambem nao reconheceram na Stegomyia, em captiseiro, um mosquito recalcitrante o estourate trecho da carta de um Dr. Low. da Trindade: - If one introduces one's hand into the cage they quickly settle on the hand and probe with their proboscis, but they never poncture and I bave nerer seen blood in the slomachs of bundreds I baze examined. . . . . Ainda uma vez estou tentado a formular a pergunta, se talvez a Stegomyia na ilha da Trindade se comporta cle outra maneira do que aqui no Brazil?

Recalcitrante achei o Culex fatigans, este sim, correspondendo assim ao eshoço de caracter e indole, qual já o traçou Grassi (loc. cit. 77 ) dos representantes sul-europeus do genero Culex. Por outro lado posso affirmar que alyuns dos nossos representantes sylvestres, do mesmo genero, como C. confirmatus, C. serralus, picam regularmente no captiveiro, como picam varias especies dos generos Taeniorbuclus - Panoplifes - Ianthinosoma, - Sabethes - Limatus. 
No dia 5 de setembro appareceu uma nova postura, de 44 ovos, (36 dias de captiveiro), precedida de 3 rações de sangue. Observação das primeiras larvas em 10 de setembro (intervallo de 5 dias); os ovos eram tambem desta vez ferteis. Postura por sua vez isolada e posta em boccal de observação separado.

No dia 7 de setembro ambas as femeas tomaram novamente uma ração de sangue de cobaya, morrendo porém uma no dia seguinte (com 39 dias de captiveiro), e perecendo igualmente a ultima no dia 11 de setembro (com 42 dias de captiveiro), sem deixarem ainda uma ultima vez descendencia.

Assim nao houve postura nenhuma durante os primeiros 23 dias de alimentaça com mel e logo depois houve 3 posturas, depois de introdusida a alimentacão com sangue.

Tocou assim para uma das duas femeas duas posturas, phenomeno interessante, indicio de que (assim habilitam-me a diagnosticar repetidas experiencias) estas mesmas posturas não eram o que estou tentado a chamar completas, mas sim parciaes, fraccionadas (circumstancia que se vê tambem pelo numero dos ovos: $36,35,44$, que eu estimo importar n'um terço ou na metade de uma postura normal) e que attribuo a um processo defeituoso, quer que o numero de rações de sangue tenha sido insufficiente, quer porque o fosse o quantum total de sangue haurido.

\section{Caixa A.}

Das 5 femeas, entradas em 1 de agosto, retirou-se no dia 26 de agosto uma d'esta caixa, simultaneamente com uma das 9 femeas da caixa B. Tinham sido alimentadas durante 26 dias sob o regimen exclusivo de mel e agua. Foram postas em gaiola separada, recebendo sangue humano (offerecendo-lhe a mão atravez da tela), que acceitaram. Por desastre mallogrou-se a experiencia, morrendo ambas estas femeas, antes de ser obtido o resultado desejado.

No dia 18 de setembro, retirou-se do mesmo modo, uma outra femea da caixa A, juntando-se com uma femea nas mesmas condições da caixa $B$, em gaiola separada. Depois de ter vivido durante 48 dias debaixo do regimen alimenticio de mel, acceitaram ambas sangue n'este mesmo dia. Tendo de me ausentar do Museu e da capital do Pará entre os dias 22 até 26 de setembro, e voltando sómente no dia 26, encontrei uma postura de 33 ovos e 2 larvas muito novas (total 35; intervallo pelo menos 8 dias); ambas as femeas porém mortas. Os ovos eram ferteis, sahindo ainda mais larvas nos dias consecutivos. A criação foi posta á parte e observada em boccal especial.

Tendo morrido no dia 10 de outubro 1 femea ( 71 dias), ficaram assim na caixa A ainda 2 femeas.

Deu-se no dia 26 de setembro o facto interessante, que um macho de pequenas dimensões, livre, do laboratorio, chegando a travar conhecimento com o vidro de relogio contendo mel, e tocando casualmente na téla de arame, forçou a entrada, penetrando na gaiola, onde viveu até o dia 28 de outubro (32 dias), data em que sumiu-se da mesma maneira pela qual se tinha introduzido. Contimuando sempre a serem tratados com mel e agua, mudou-se de regimen no dia $1+$ de outubro de 1903, (depois de 75 dias de mel), offerecendo-lhes sangue. Tomaram uma ração successivamente nos dias: 
14 de outubro ( 75 dias) sangue humano;

17 de outubro (78 dias) id. id.

19 de outubro ( 80 dias) sangue de cobaya.

Sobreveio a morte de uma das duas ultimas femeas no dia 23 de outubro ( 84 dias), ficando uma sómente.

Esta tomou ainda uma vez sangue no dia 23 de outubro ( 84 dias), (sangue de cobaya) e mais outra ração (sangue humano) no dia 4 de novembro ( 95 dias). N'este mesmo dia foi observado 1 ovo isolado na bacia, (além de 1 larva, esta observada pela primeira vez no dia 27 de outubro). (1) No dia 9 de novembro achou-se mais 1 ovo (além de uma larva, esta observada pela primeira vez no dia 8 de novembro), (2) e na manhan seguinte, 10 de novembro, 85 ovos. Horreu assim esta femea de Stegomyia fasciata, n'este mesmo dia, com 102 dias de vida no captiveiro, pondo no ultimo dia ainda uma postura completa de 85 ovos, tendo vivido 75 dias debaixo do regimen de mel (sem pôr ovos) e durante os ultimos 27 dias debaixo do regimen de sangue (5 raçơes)!

D'estes 85 ovos, na verdade, não saíram larvas até hoje, mas attribuo isto unicamente ao acontecimento casual, de terem elles submergido da tona d'agua, por um empurrão involuntario logo nos primeiros dias na bacia que os continha. (Tenho reconheciclo na submersão um phenomeno fatal para o desenvolvimento dos ovos dos mosquitos: póde-se dizer que ovo que se afoga, é ovo perdido, morto). Julgo poder opinar pela fertilidade normal d'aquelles ovos, porque tendo sido positivamente encontrados na mesma bacia ovos fornecendo larvas no $88^{\circ}$ e $100^{\circ}$ dia, não vejo razão pela qual não se podésse admittir ser o mesmo para os ovos do $102^{\circ}$ dia.

\section{Caixa B.}

Retiradas, como acima ficou dito, nos dias 26 de agosto e 18 de setembro de 1903, uma femea cada vez, permaneceram na caixa, das 9 que eram no dia 1 de agosto, ainda 7. Para os inquilinos d'esta caixa manteve-se o regimen alimenticio exclusivo de mel e agua. Os acontecimentos foram os seguintes:

dia 5 de setembro de 1903, morreu 1 femea (36 dias de captiveiro); dia 14 de setembro, morreram 2 femeas ( 45 dias de captiveiro); dia 26 de setembro, morreu 1 femea ( 57 dias de captiveiro); dia 3 de outubro, morreram 2 femeas ( 64 dias de captiveiro); dia 4 de outubro, morreu a ultima femea ( 65 dias de captiveiro).

Nenhuma d'estas 7 femeas, alimentadas com mel, forneceu sequer um unico ozo, quanto mais una postura normal de ovos!

(1) I)'esta larva saiu um mosquito macho, de pequena corpulencia, no dia 22 de novembro de 1900; (intervallo minimo, 26 dias ).

(2) D'esta larva saiu uma Stegomyia femea, pequena, no dia 24 de novembro de 1903; (intervallo minimo 16 


\section{EXPERIENCIA}

De 9 femeas de Stegomyia, apanhadas em liberdade, e postas em gaiola no dia 14 de agosto de 1903, e nutridas com uma ração de sangue humano no mesmo dia, appareceu uma primeira postura já no dia 16 de agosto, (intervallo de 2 dias).

\section{EXPERIENCIA 3.}

Foram postas em gaiola 8 femeas, apanhadas em liberdade, no dia 1 de agosto de 1903. Receberam rações de sangue de cobaya nos seguintes dias:

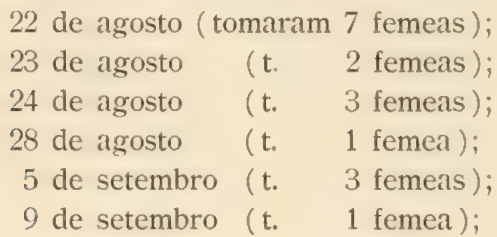

Obtive posturas de ovos em:

I) 22 de agosto - 15 ovos.

II) 24 de agosto -120 ovos. (Intervallo minimo $2-4$ dias).

III) 26 de agosto - 9 ovos.

$I V) 9$ de setembro -90 ovos.

Os ovos eram ferteis; acompanhei larvas da 4 a postura no seu desenvolvimento. - Quanto á 1.a postura do dia 22 de agosto, a respectiva femea a forneceu visivelmente devido ainda á intervenção de sangue anteriormente apanhado na liberdade, antes de entrar em gaiola.

\section{EXPERIENCIA 4.}

Tres femeas de Stegomyia, apanhadas em liberdade, e engaioladas no dia 1 de setembro de 1903, receberam uma ração de sangue humano no mesmo dia (uma só acceitou, 2 não acceitaram; no dia 3 de setembro todas trez recusaram).

Appareceu uma pequena postura de 15 ovos no dia 4 de setembro, (intervallo de 3 dias). Ovos ferteis.

\section{EXPERIENCIA 5.}

Uma femea de Stegomyia, apanhada em liberdade, posta em gaiola no dia 23 de agosto de 1903, e tendo recebido uma ração de sangue humano no mesmo dia, forneceu uma postura de 35 ovos no dia 26 de agosto (intervallo de 8 dias). - Ovos ferteis. 


\section{EXPERIENCIA 6.}

8 femeas de Stegomyia, apanhadas em liberdade, postas em gaiola no dia 30 de setembro de 1903 , receberam rações de sangue de cobaya:

no dia 30 de setembro;

no dia 3 de outubro;

Obtive uma postura de 37 ovos no dia 8 de outubro de 1903, (intervallo de 8-5 dias). - Os ovos eram ferteis; acompanhei as larvas.

\section{EXPERIENCIA $\mathbf{7}$.}

4 femeas de Stegomyia, apanhadas em liberdade e presas em gaiola no dia 3 de novembro de 1903, receberam sangue de cobaya nas seguintes datas:

dia 4 de novembro tomaram ração todas 4 );

dia 7 de novembro (t. 2 );

dia 9 de novembro (t. 1 );

dia 11 de novembro (t. 2);

Obtive uma primeira postura completa de 105 ovos no dia 7 de novembro de 1903, (intervallo de 4 dias). - Ovos provadamente ferteis. Segunda postura de 30 ovos no dia 14 de novembro.

\section{EXXPERENCIA 8.}

2 femeas de Stegomyia, apanhadas em liberdade e postas em gaiola no dia 22 de novembro, receberam uma ração de sangue humano. Appareceram 4 ovos no dia 25 de novembro e mais 11 ovos na manhan seguinte, 26 de novembro. Total 15 ovos, (intervallo de 3-4 dias), todos ferteis.

\section{EXPERIENCIA}

1 femea de Stegomyia, apanhada em liberdade no dia 9 de novembro de 1903 , recebeu sangue humano da seguinte fórma:

9 de novembro;

11 de novembro;

16 de novembro;

17 de novembro;

A femea morreu no dia 20 de novembro, tendo deixado uma progenitura de 
cento e tantos oros, (intervallo maximo, 11 dias; minimo, 3 dias.) - (Não existe annotação relativa á questão se os ovos se desenvolveram ).

\section{EXPERIENCIA 10.}

As femeas de Stegomyia, apanhadas em liberdade e engaioladas no dia 14 de outubro de 1903, receberam rações de sangue de cobaya nas datas:

15 de outubro ( 3 );

17 de outubro (2);

20 de outubro (1);

Appareceu a $1^{\text {a }}$. postura ( 25 ovos), no dia 16 de outubro (intervallo de 2 dias). -Oros ferteis; criei mosquitos d'esta postura.

\section{EXXPERIENCIA 11.}

A uma femea de Stegomyia, apparentemente vasia, apanhada em liberdade no dia 10 de novembro de 1903 , se juntaram em 11 de novembro mais trez femeas nas mesmas condições (morrendo entretanto uma em 14 de novembro), e finalmente, mais cinco femeas em identicas circumstancias, no dia 15 de novembro de 1903, sendo o total da caixa 8.

Foram tratadas com o regimem do mel e não receberam sangue.

Appareceram todavia no dia 29 de novembro, 36 ovos e 4 larvas. Tendo-se retirado em 8 de dezembro uma femea para a caixa VII, da qual logo fallarei, e tendo morrido até o dia 24 de dezembro, 4 femeas, restam hoje ainda 3 ( 29 de dezembro de 1903 ).

Os ovos eram ferteis, pois até o dia 4 de dezembro tinham sahido 36 larvas.

Sou levado a suppor que o apparecimento um tanto surprehendente á primeira vista de uma postura de oros ferteis, depois de um intervallo de captiveiro de 15 para 19 dias, com regimen alimenticio exclusivo de mel durante este periodo, fosse devido a uma influencia, embora tardia, de rações de sangue hauridas quando $\mathrm{cm}$ liberdade, anteriormente á data do aprisionamento, (10, 11 e 15 de dezembro).

\section{EXPERIENCIA 12.}

Tres femeas de Stegomyia, apparentemente vasias, foram apanhadas em liberdade, na residencia directorial, no dia 28 de novembro de 1903 , e postas em gaiola, igualmente para serem submettidas ao regimen de mel e agua.

Todavia appareceu uma postura de 40 ovos no dia 4 de dezembro, (intervallo, 6 dias), morrendo logo a respectiva femea. Ovos ferteis. (Retirou-se no dia 8 de dezembro uma femea para a caixa 7, como na experiencia anterior, ficando 1 só na gaiola na data de hoje (29 de dezembro de 1903). 
Ainda uma vez explico-me este caso pela mesma fórma, como na experiencia 11. a, servindo de prova material e pedra de toque $o$ resultado obtido com as duas femeas retiradas, no modo acima referido, no dia 8 de dezembro e ao qual logo voltarei.

\section{EXPLRIENCIA 13.}

As duas femeas, (originalmente apanhadas em liberdade), de que fallei nas experiencias $11 .^{a}$ e 12 a , e que foram retiradas de duas gaiolas diversas no dia 8 de dezembro de 1903, cujos inquilinos estavam submettidos desde o principio $(10,15$ e 28 de novembro) ao regimen exclusivo de mel e agua, foram reunidas no mesmo dia $8 d c$ dezembro em gaiola distincta, juntando-se a ellas um exemplar macho de Stegomyia, apanhado em liberdade.

Continuou estrictamente observado o regimen alimenticio de mel e agua.

Nenhuma postura, nem ovo isolado, appareceu até hoje - 30 de dezembro de 1903 - decorridos, no momento em que escrevo, 22 dias.

\section{EXPERIENCIA 14.a}

As duas femeas, criadas desde o estado pupal no captiveiro, em severo isolamento (cada uma em tubo de vidro), virgens até aquella data, foram reunidas no mesmo dia de 8 de dezembro em gaiola separada com dous machos de Stegomyia, igualmente criados no captiveiro, debaixo das mesmas cautellas.

Continuou-se o regimen de mel e de agua.

Até hoje, 30 de dezembro, 1903 (decorridos tambem 22 dias) nenhuma postura, nem se quer um ovo isolado.

\section{EXPERIENCIA 15.}

(N. B. Recentemente introduzi a seguinte innovaçăo para maior commodidade é para ter sempre á mão numero sufficiente de Stegomyias, de ambos os sexos, criados desde larvas e pupas em estricto isolamento: tenho duas gaiolas, nas quaes vou introduzindo successivamente, n'uma todas as femeas que vão sahindo nos tubos isolados, e na outra todos os machos que se desenvolveram em seus tubos nas mesmas condições. Faz-se isto com a intenção evidente de ter á mão material de Stegomyias, garantido como não tendo tido occasião de realisar copula sexual. O tratamento em ambas as caixas é o de mel e agua rigorosamente observado. Tenho, na hora em que escrevo, n'uma d'estas duas caixas, 18 femeas, e na outra 23 machos, variando naturalmente, constantemente este inventario vivo d'estas duas caixas - que eu chamarei caixas de deposito e das quaes vou retirando individuos de Stegomyia de ambos os sexos, á proporção que vou d'elles precisando. Em 96 tubos de vidro com agua, fechados com um tampão de 
algodão, criam-se constantemente as larvas, á medida que ellas vão attingindo o desenvolvimento para entrar na phase de chrysalida ou pupa. Como material para os boccaes de criação vou-me servindo principalmente de larvas procuradas em liberdade, nas visinhanças do Museu.)

Duas femeas de Stegomyia, criadas no captiveiro, virgens e retiradas da alludida caixa de deposito (regimen de mel), em 22 de dezembro de 1903, foram postas em gaiola separada e receberam no mesmo dia sangue humano, que ambas logo acceitaram. Tomou uma d'ellas segunda ração de sangue humano no dia 25 de dezembro de 1903.

Até a data em que escrevo, 31 de dezembro, não appareceram ovos.

\section{EXPERIENCIA 16.}

Duas femeas de Stegomyia, criadas no captiveiro do mesmo modo, em rigorosa reclusão, e retirada da respectiva caixa de deposito no dia 22 de dezembro de 1903, (regimen de mel) foram reunidas na mesma data em caixa separada com 2 individuos machos, retirados por sua vez da competente caixa de deposito.

Receberam e acceitaram sangue humano ambas pela primeira vez n'este mesmo dia 22 de dezembro: uma d'ellas acceitou segunda ração de sangue humano no dia 25 de dezembro. (Morreu 1 macho no dia 28 de dezembro).

Appareceram na bacia d'agua 6 ovos no dia 29 de dezembro (intervallo maximo 7 dias, minimo 4 dias), e foi encontrada uma segunda postura, igualmente fraca, pois só consiste de 13 ovos, no dia 31 de dezembro. Estes ovos são postos em observação, afim de apurar da sua fertilidade.

\section{EXXERIENCIA 17.a}

Reuniram-se n'uma caixa isolada as seguintes femeas, criadas no captiveiro todas em absoluto isolamento individual, virgens :

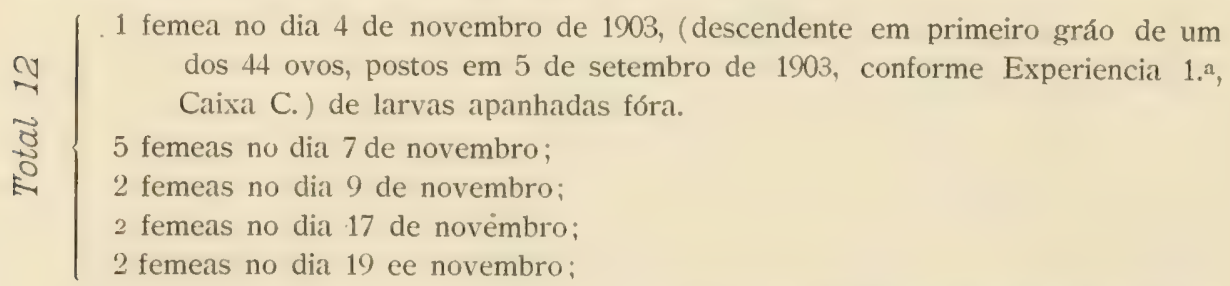

Estabeleceu-se o regimen alimenticio de sangue humano, offerecendo-se rações:

no dia 4 de novembro de 1903 (1);

no dia 7 de novembro (3),

no dia 9 de (novembro (manhan) (4);

no " " de ( novembro (tarde) (2):

no dia 11 de novembro (5):

no dia 13 de novembro (2): 
No dia 15 de novembro appareceu uma pequena postura de 7 ovos apenas, fugindo casualmente a respectiva mãe. (Intervallo maximo 11 dias; minimo 2 dias).

Dos 5 mosquitos femeas restantes no dia 15 de novembro e entrados depois d'aquella data, tomaram ainda sangue humano:

no dia 16 de novembro (1);

no dia 17 » $\quad(3)$;

no dia 19 " " (3);

acontecendo porem infelizmente a fuga e a morte por uma pequena aranha (Salticida) intrusa, de maneira que no dia 22 de novembro estava tudo liquidado, antes que eu tivesse conseguido ainda outras posturas ulteriores.

Dos 7 ovos, apezar de fluctuando regularmente, não sahiram larvas até hoje ( 30 de dezembro de 1903; intervallo 45 dias!): certamente são estereis, e são garantidamente pseudo-parthenogeneticos! (1)

Fica até agora, ao que eu saiba, sendo este o unico caso scientificamente averiguado de ovos pseudo-parthenogeneticos não só na especie de Stegomyia, como entre os Culicideos em geral. (2)

\section{EXPERIENCIA 18.}

Duas femeas de Stegomya, criadas em isolamento individual no captiveiro e retiradas da caixa de deposito no dia 22 de dezembro de 1903 (regimen de mel), virgens, receberam e acceitaram sangue humano na tarde do mesmo dia 22 de dezembro (a primeira de 4 h. $35^{\mathrm{m}}$. p. m. -4 h. $45^{\mathrm{m}}$, a segunda das 7 h. $35^{\mathrm{m}}$. -7 h. $43^{\mathrm{m}}$ ).

No dia 25 de dezembro uma tomou sangue pela segunda vez (4 h. da tarde) emquanto que a outra não o quiz.

Morreu no dia 30 de dezembro uma d'estas duas femeas, sem ter produzido ovos, (intervallo de 8 dias) ao passo que a ultima sobreviveu mais um dia, fornecendo 23 ovos na bacia d'agua, morrendo em 31 de dezembro incontinenti depois de finda a funcção (intervallo de 9 dias). Os ovos serão postos em observação afim de averiguar o seu comportamento debaixo do ponto de vista da sua naturalmente problematica fertilidade

Eis pois um segundo caso scientificamente constatado de ovos pseudc-parte-

(1) Eu posso reconhecer como lecritima a parthenogeneses sómente o caso onde uma femea fornece seus similiares (productos que alcançam completa maturidade) sem previa intervençĩo de copula sexual.

Não havendo porém um termo que exprimisse simplesmente o facto da postura de ovos não fecundados e que não se desenvolvem ulteriormente. introduzi aqui a designação de epseudo-parthenogenese .

(2) Nuttal e Shipley (loc. cit, par. 67 - seg.) ded:cam á parthenogenese uma nota especial, referindo um caso, que parece ainda envolto em certas duvidas, descripto por Howard sob a autoridade de Kelloge na California (nem genero nem especie conhecida) e um outro annunciado de Annett, Dutton e Elliot (1901), relativo a certa especie de Ano. pheles, na Nigeria. No primeiro diz-se que houve larvas, que quasi alcançaram a maturidade; no segundo apenas ovos, dos quaes não sahiram larvas. Imaurines não houve em nenhum dos 2 casos.

Recentemente L uhe fez d'este assumpto objecto de uma nota critica assaz desenvolvida ( . Zur Fragre der Parthenogenese bei Culiciden = Allgem. Zeitschrift) für Entomologie. Vol VIII, N: 18-19, Octob, 1903, pag. 372- seg. Vé-se que o autor se consersa n'uma posiçáo de pronunciado septicismo perante todos os casos de pretendida parthenogenese entre mosquitos até agora enumerados na litteratura scientifica. 
nogeneticos postos por uma femea de Stegomyia virgem, depois de ter haurido sangue. Intervallo entre $1^{a}$. ração de sangue e postura -9 dias; idem entre 2 rações de sangue -6 dias.

E' interessante esta experiencia, tanto em comparação com a anterior (17.a ), como pelo parallelismo existente com a experiencia simultanea 16.a , onde os elementos eram $\mathrm{cm}$ tudo identicos, com a unica excepção de ter entrado ahi o factor da sexualidade pela intencional intervenção de individuos machos.

\section{EXPERIENCIA 19.a}

Entraram em gaiola separada, no dia 30 de agosto 2 individuos machos de Stegomyia e no dia 31 de agosto mais 3 machos, todos estes 5 apanhados em liberdade. Submetteram-se ao regimen exclusivo de MEL e agua.

Morrendo 3 logo nos primeiros dias, resistiu um até o dia 26 de setembro ( 28 dias), e quanto ao ultimo, conseguiu fugir ainda atravez das malhas, no dia 10 de novembro após $\mathbf{7 2}$ dias passados no captiveiro!

\section{EXPERIENCIA 20.}

7 machos de Stegomyia, apanhados em liberdade foram postos no dia 30 de agosto em gaiola separada, dando-se-lhes por um lado sómente agua, porém experimen. tando-se repetidas vezes, durante os proximos dias se acceitavam savgue humano e de cobaya. Não quizeram, preferindo morrer todos até a tarde do dia 2 de setembro de 1903 (maximo 4 dias).

\section{EXPERIENCIA 21. ${ }^{a}$}

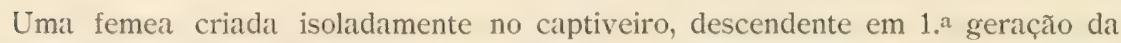
centenaria historiada na experiencia 1. a, caixa $\mathrm{A}$, (ovo encontrado em 8 de novembro de 1903, virando imagem em 24 de novembro de 1903), (intervallo minimo 16 dias), foi posto em gaiola separada com regimen de mel e agua.

Viveu até o día 29 de dezembro, morrendo depois de $\mathbf{3 5}$ dias de captiveiro, de morte violenta, pois foi victima de uma aranha, que soube introduzir-se pela tela.

Era de pequena estatura. Morreu virgem, não tendo fornecido quaesquer ovos.

\section{EXXERIENCIA 22.}

Trez femeas de Stegonyia, criadas em isolamento no captiveiro, entraram n'uma gaiola separada no dia 28 de novembro de 1903, recebendo alimentação de $m e l$ e agua.

Retirando-se no dia 8 de dezembro de 1903 uma d'ellas (para entrar na caixa 9; uma das duas femeas mencionadas na experiencia $14 .^{a}$ ), ficaram duas, das quaes a ultima morreu no dia 30 de dezembro de 1903, com 32 dias de vida no captiveiro. 


\section{EXPERIENCIA 23.a (1)}

\section{Caixa A.}

Duas femeas de Stegomyia, criadas no captiveiro, em isolamento individual, retiradas da respectiva caixa de deposito, installada em 11 de novembro, foram postas em gaiola separada no dia 29 de dezembro de 1903. Continuação da alimentação com mel até o dia 20 de janeiro de 1904 .

No dia 22 de janeiro tomaram sangue humano 2 femeas;

no dia 25 de janeiro tomou sangue humano 1 femea; (a outra desappareceu);

no dia 29 de janeiro, tomou sangue humano 1 femea;

no dia 1 de fevereiro, tomou sangue humano 1 femea, morrendo n'este mesmo dia, 1 de fevereiro, sem ter posto um unico ovo, tendo vivido no minimo 35 dias (prazo possivel 47 dias), e tendo haurido 4 vezes sangue.

\section{Caixa $A^{\text {: }}$}

Duas femeas de Stegomyia, em condições inteiramente identicas, foram postas em gaiola separada no dia 29 de dezembro, continuando todavia o estricto regimen alimenticio de mel.

As duas femeas não puzeram até agora um unico ovo, vivendo ainda hoje ( 15 de fevereiro de 1904) com 48 dias de vida no minimo.

\section{Caixa B.}

Com duas femeas, nas mesmas condições acima referidas, juntaram-se no dia 29 de dezembro dois machos, criados nas mesmas circumstancias, n'uma gaiola separada. Continuando-se com o regimen de mel até o dia 20 de janeiro de 190t, offereceu-se-lhes a primeira vez sangue humano:

tomando no dia 20 de janeiro as duas femeas;

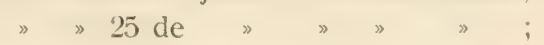

apparecendo uma primeira fraca postura -6 ovos, - no dia 29 de janeiro de 1904 , e no dia 31 de janeiro uma segunda postura de mais 62 ovos.

Tomando sangue humano novamente

no dia 6 de fevereiro as duas femeas, e

no dia 11 de $"$ », , appareceu no dia 10 de fevereiro de 1904 uma terceira postura de 41 ovos.

Tendo-se deixado a pequena vasilha com mel, vivem ainda hoje ( 15 de fevereiro de 1904) os dous casaes perfeitamente, com 48 dias de vida no minimo.

Ovos fecundos, acompanharam-se as larvas.

\section{Caixa B'.}

Com outras duas femeas e outros dous machos, foram observadas em tudo condições exactamente iguaes, com a unica excepção de continuar para esta gaiola o estricto regimen de mel. 
Vivem ainda hoje (15 de fevereiro de 1904) os 4 inquilinos, não tendo porém as duas femeas fornecido ovo algum durante todo este tempo.

N. B. Facilmente se percebe que ha entre as caixas $A$ e $A^{1}$ igualdade de condiçðes na ausencia do factor da copula sexual, mas desigualdade na alimentação. Por outro lado ha concordancia entre A e B na applicação da alimentação com sangue, como discordancia das condições sexuaes, e ha outra vez harmonia entre $\mathrm{A}^{1}$ e $\mathrm{B}^{1}$ nç conservação da alimentação de mel, com simultanea desharmonia quanto ao factor sexual.

Ora, nato deixa de ser muito significativo que posturas de ovos-(e estes sendo ferteis) - só se observaram na caixa B: applicaçao de sangue e copula sexual!

\section{EXPERIENCIA 24.}

\section{Caixa A.}

A duas femeas de Stegomyia, criadas no captiveiro em rigoroso isolamento individual, retiradas da respectiva caixa de deposito, juntaram-se dous machos, criados em igualdade de circumstancias, no dia 30 de dezembro de 1903. Offereceu-se-1hes sangue de cobaya no dia 31 de dezembro de 1903, tomou 1; idem, id., no dia 2 de janeiro de 1904 , tomou 1, retirando-se de uma a vasilha com mel.

No dia 4 de janeiro appareceu uma postura de 92 ovos, (intervallo 4 dias) encontrando-se morrendo a respectiva femea (os dous machos morreram n'este mesmo dia) e no dia 9 de janeiro morreu a ultima femea, sem ter posto ovos. Ovos ferteis. Larvas.

\section{Caixa B.}

A duas outras femeas, idem, idem, juntaram-se dous outros machos, idem, idem, na mesma data, (dia 30 de dezembro de 1903), offerecendo-lhes sangue humano e retirando-se a vasilha com mel.

No dia 2 de janeiro, tomou uma, (a outra fugiu).

No dia 6 de janeiro appareceu uma postura de 33 ovos, morrendo a respectiva femea no dia 9 de janeiro, sem ter mais haurido sangue e sem ter posto outros ovos. (Dos dous machos, morreu um no dia 19 de janeiro com 20 dias, e o outro no dia 21 de janeiro, com 22 dias). Ovos ferteis. Larvas.

x. B. Nota-se que esta experiencia tinha o fim de averiguar a qualidade do sangue na sua influencia sobre a postura dos oros. Tendo sido porém algo viciada pela recusa de uma femea na caixa $\mathrm{A}$ e pela fuga de uma femea na caixa $\mathrm{B}$, resolveu-se repetil-â.

\section{EXPERIENCIA 25.}

Caixa C.

Duas femeas e duos machos, idem, idem, reunidos n'uma gaiola no dia 3 de fe- 
vereiro de 1904. Administração de sangue humano no dia 6 de fevereiro, tomaram 2 femeas.

No dia 11 de fevereiro appareceu uma postura de 52 ovos, (intervallo 5 dias). N'este mesmo dia ( 2 de fevereiro), tomaram sangue humano ambas as femeas, vivendo ainda em 15 de fevereiro. (Dos machos morreu um no dia 9, o outro no dia 11 de fevereiro ).

\section{Caixa D.}

Duas femeas e dous machos, idem, idem, reunidos n'uma gaiola no dia 3 de fevereiro de 1904. Administração de sangue de cobaya: no dia 6 de fevereiro tomaram as duas femeas. No dia 11 de fevereiro appareceu uma fraca postura de 7 ovos, (intervallo 5 dias), morrendo a respectiva femea na tarde do mesmo.

A femea restante tomou sangue de cobaya pela segunda vez, no dia 11 de fevereiro, não apparecendo ovos antes do dia 15 de fevereiro, em que escrevo. (Os machos morreram ambos, logo no dia 5 de fevereiro).

N. B. Concordo que estas duas experiencias ainda não liquidam o problema satisfactoriamente. Mas creio prever que, de uma maior serie de experiencias no mesmo sentido, resultará uma perceptivel vantagem qualitativa para o sangue humano sobre o sangue de cobaya.

Experiencias sobre o intervallo de tempo entre a primeira rafáo de sangue $e$ a data da postura dos ovos. (Resumo synoptico extrahido das minhas annotações).

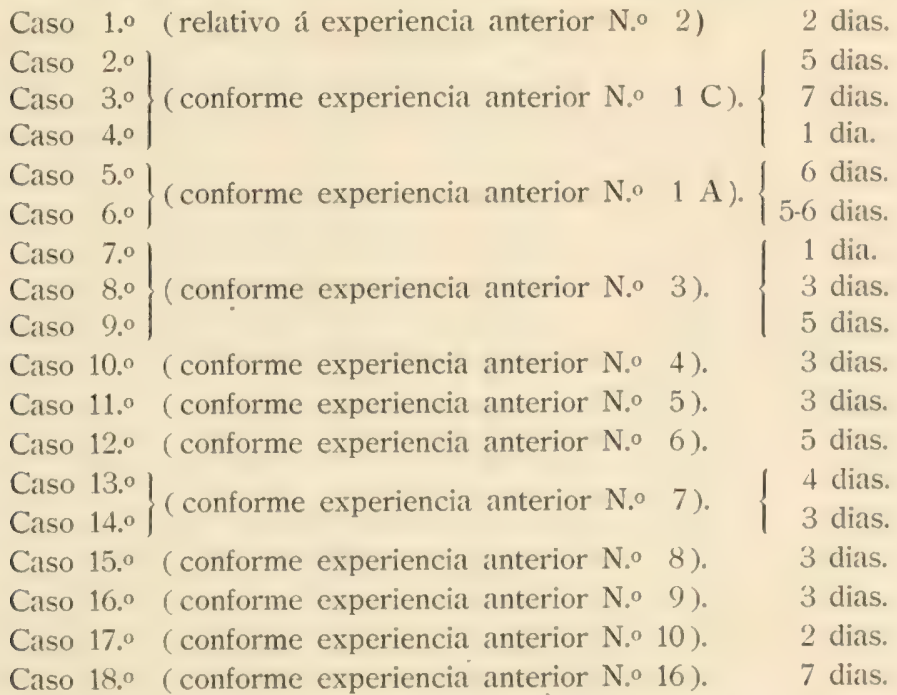

N'esta serie de 18 casos o maximo é de 7 dias (duas vezes); o minimo de 1 dia 
(tambem duas vezes); 2 dias (duas vezes); 3 dias (seis vezes), etc. A media arithmetica 3,7 dias $=90 \frac{2}{3}$ horas approxima-se tambem bastante d'este numero. (1)

Experiencias sobre o tempo de sobrevioencia das femeas ao acto da postura dos ovos. Resumo:

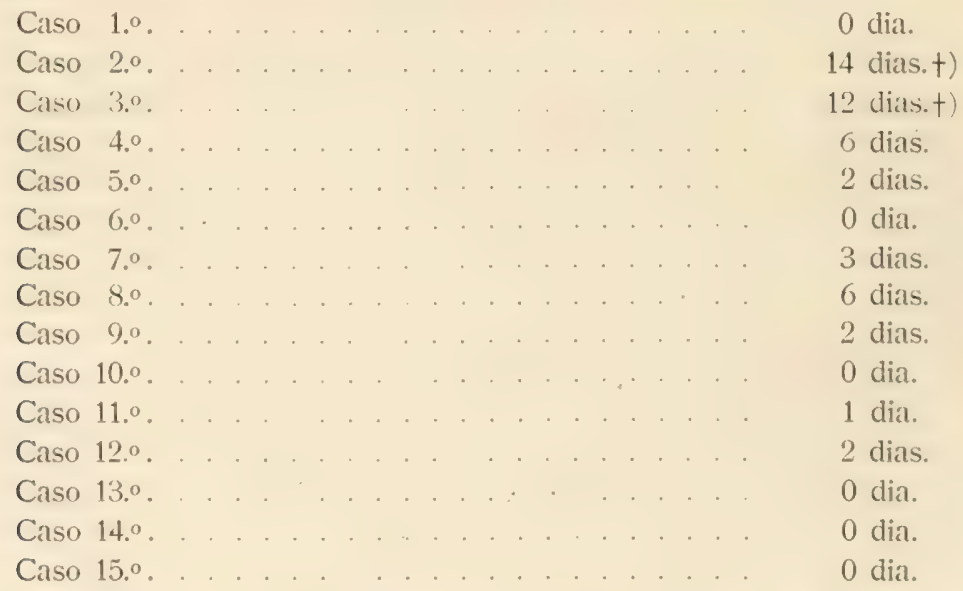

N'esta serie de 15 casos o maximo é de 14 dias; houve por outro lado 6 casos de menos de dia (morte immediata depois da postura dos ovos), perto de $40 \%$. (2)

Houve ainda 1 caso de um dia, 3 casos de 2 dias, 1 de 3 dias. Tratando-se nos N. ${ }^{\circ} 2$ e $3+$ de casos de posturas provadamente muito pouco numerosas e insufficientes (conf. experiencia N.o 1, C), não poderão modificar o facto empirico, de que a femea costuma morrer, por via de regra, logo ou nos dias immediatos a uma postura completa.

Experiencias sobre o intervallo de tempo que levam as larvas nozas, para salirem dos ovos recem-postos. Resumo:

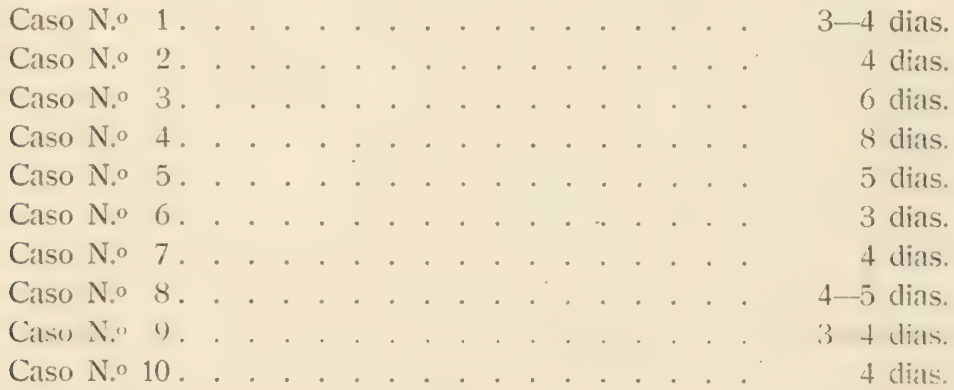

(1) $\mathrm{km}+$ casos posteriores houve + dias ( 2 vezes) e +-5 dias ( 2 vezes ).

(2) Em 3 casos posteriores observousse morte immediata (1) dia) 2 vezes e sobrevivencia de 3 dias uma vez. 
Entre estes 10 casos o maximo é de 8 dias; o minimo é de 3 para 4 dias ( 3 vezes); 4 dias (3 vezes;) $4-5$ dias e 5 dias ( 1 vez cada).

A media arithmetica de 4,5 dias.

Experiencia sobre a duragâo do cyclo inteiro, desde a data da postura dos ovos até a sahida das imagines (mosquitos alados). Resumo :

Caso $10^{\circ}$. . . . . . . . . 12 dias $(t)-16$ dias.

Caso $20^{\circ}$. . . . . . . . . . . 13 dias.

Caso $30^{\circ}$. . . . . . . . . . . 29 dias.

Caso $40^{\circ}$. . . . . . . . . . . 21 dias.

Caso $50^{\circ}$. . . . . . . . . 23 dias.

Caso $60^{\circ} \ldots . . . . . . .31$ dias. -44 dias.

Caso $70^{\circ}$. . . . . . . . 17 dias. -18 dias.

$\mathrm{O}$ que é de especial interesse aqui são os casos de duraço minima (12 dias) $t$, ao passo que a duração maxima é indefinida e quasi illimitada, conforme a estação do anno e a alimentação mais ou menos farta.

Observei um caso, onde um mosquito Stegomyia (macho) levou 50 para sahir e outros casos onde, com igual numero de dias, havia ainda larvas e pupas.

Experiencia sobre a duraça da vida no captiveiro, debaixo da influencia da alimentracão. Resumo:

Extrahi os seguintes dados das minhas annotações, relativas ás femeas de Stegomyia, submettidas ao regimen de mel, ou ao regimen mixto, depois de um certo tempo de alimentação exclusiva com mel: (1)

Femeas:

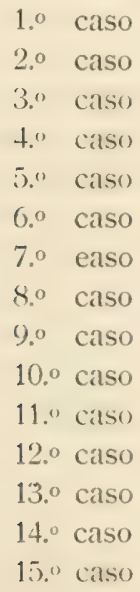

\begin{tabular}{|c|c|}
\hline 1 dias (2 & vezes \\
\hline 2 dias ( 1 & rez \\
\hline diats ( 1 & , \\
\hline dias ( 1 & \\
\hline diats ( 1 & \\
\hline dias (1 & \\
\hline ias $(4$ & vezes \\
\hline dias ( 1 & vez \\
\hline 0 dias (2 & vezes \\
\hline dias (1 & vez \\
\hline dials ( 1 & , \\
\hline dias (1 & 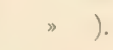 \\
\hline dias ( 1 & . \\
\hline dias (1 & \\
\hline ias & \\
\hline
\end{tabular}

(1) Tratando se aqui de determinar a duração muxima, deixei propositalmente fóra da synopse todos os valores inferiores a 30 dias. 
Machos:

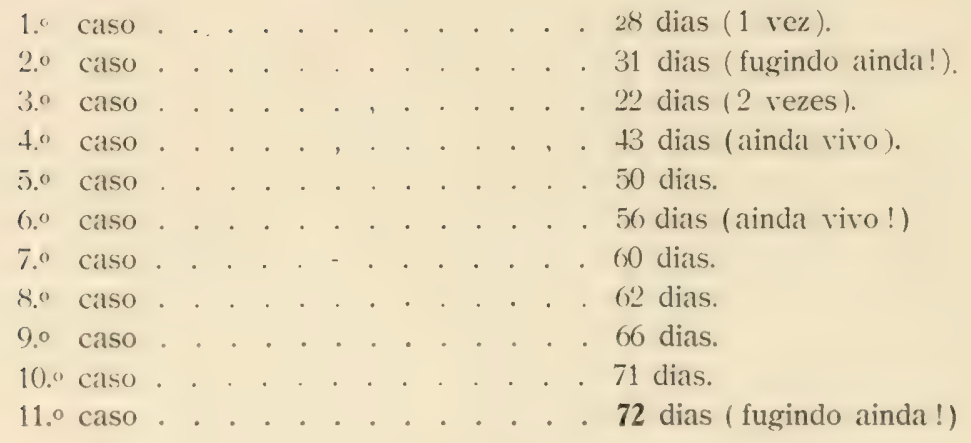

\section{CULEX FATIGANS}

\section{EXPERIENCIA 1.a}

10 femeas de Culex fatigans, apanhadas na residencia directorial na vespera, tendo chupado sangue humano, entraram em gaiola separada no dia 11 de agosto de 1903.

Appareceram as duas primeiras posturas de ovos (as caracteristicas jangadas) em 15 de agosto [intervallo 4 dias ]. Jangadas normaes, ovos ferteis. As duas femeas morreram logo. Duração no captiveiro, 4 dias.

\section{EXPERIENCIA 2.}

2 femeas, apanhadas em identicas condições, repletas de sangue humano, entraram em gaiola do dia 12 de agosto de 1903.

Encontraram-se duas jangadas normaes de ovos no dia 16 de agosto (intervallo, 4 dias). Ovos ferteis; observei as larvas. Uma das femeas sobreviveu ao acto 2 dias. Duração da vida no captiveiro, 6 dias.

\section{EXPERIENCIA 3.}

2 femeas, capturadas em condições semelhantes, repletas de sangue humano, entraram em gaiola no dia 17 de agosto de 1903.

Observaram-se jangadas normaes de ovos em 21 de agosto, (intervallo 4 dias). Ovos ferteis; larvas observadas. Sobreviveram as duas femeas ao parto 2 a 3 dias. Duração total da vida no captiveiro, $6-7$ dias. 


\section{EXPERIENCIA 4.a}

3 femeas de Culex fatigans (e 1 individuo macho da mesma especie), tendo sido apanhadas em estado repleto de sangue humano, entraram em gaiola separada no dia 15 de agosto de 1903.

Notei a primeira jangada normal de ovos em 19 de agosto, (intervallo 4 dias). Ovos ferteis. Morreu a respectiva femea logo na mesma manhan. Duração da vida no captiveiro, 4 dias.

\section{EXPERIENCIA 5.a}

De 2 femeas Culex fatigans, enclausuradas depois de identicos precedentes e em iguaes circumstancias no dia 16 de agosto de 1903, obtive a primeira jangada de ovos no dia 19 de agosto, (intervallo, 3 dias).

Morreu a respectiva femea no mesmo dia, tendo durado a sua vida no captiveiro apenas 3 dias.

\section{EXPERIENCIA 6.a}

Outras duas femeas, em iguaes circumstancias, entraram no mesmo dia, 16 de agosto de 1903, em outra caixa.

Appareceu igualmente uma jangada de ovos no dia 19 de agosto, (intervallo 3 dias).

\section{EXPERIENCIA Z.a}

De 2 femeas de Culex, repletas de sangue humano, enclausuradas no dia 14 de agosto, alcancei a primeira jangada de ovos no dia 17 de agosto, (intervallo 3 dias).

\section{EXPERIENCIA 8.a}

De outras 2 femeas, repletas de sangue humano ecapturadas no dia 17 de agosto de 1903, encontrou-se uma postura normal de ovos no dia 21 de agosto, (intervallo 4 dias ). Ovos ferteis; observei o desenvolvimento das larvas.

\section{EXFERIFNCIA 9.a}

De outras 3 femeas de Culex fatigans, em identicas circumstancias, entradas em gaiola no dia 21 de agosto de 1903, descobri a primeira jangada de ovos em 25 de agosto, (intervallo, 4 dias). Os ovos igualmente fecundos; accompanhei as larvas no seu crescimento. 


\section{EXPERIENCIA 10.}

Outras 3 femeas, nas mesmas condiçz̃es, entraram em caixa na mesma data, 21 de agosto, observando-se uma primeira postura de ovos na manhan do dia 25 de agosto, (intervallo 4 dias).

Morreu a respectiva femea logo, (duração da vida, 4 dias), ao passo que as 2 outras morreram com $4 \frac{1}{2}$ e 5 dias, sem terem depositado os seus ovos (pelo menos não os encontrei na bacia ).

\section{EXPERIENCIA 11.}

De duas femeas, apanhadas em estado de terem tomado sangue humano em liliberdade, e que entraram em observação no dia 28 de agosto de 1903, appareceu uma pequena jangada de 15 ovos apenas, no dia 1 de setembro, (intervallo, 4 dias). Ovos ferteis. A femea morreu logo; duração da vida no captiveiro sómente 4 dias.

\section{EXPERIENCIA 12.}

Seis femeas de Culex fatigans, apanhadas com sangue humano e postas em gaiola no dia 20 de setembro de 1903. Como tive de ausentar-me do Museu e da capital do Pará durante os dias 22 a 26 de setembro, voltando no dia 26, encontrei n'aquella data na respectiva bacia d'agua as 6 jangadas de ovos correspondentes ás 6 femeas, bem como centenas de pequenas larvas de 1 a 2 dias.

\section{EXPERIENCIA 13.}

Oito femeas do mesmo mosquito, enclausuradas em identicas condições ás precedentes, no dia 28 de setembro de 1903 , forneceram 8 jangadas, que encontrei no dia 3 de outubro (depois de uma ausencia da capital durante os dias 1 e 2 de outubro). Observei igualmente centenas de novas larvas na bacia d'agua, da idade approximada de 1 a 2 dias.

\section{EXPERIENCIA 14.}

2 femeas de Culex fatigans, apanhadas em liberdade no dia 5 de outubro, não quizeram pôr ovos, vivendo apenas dois dias na gaiola.

\section{EXPERIENCIA 15.}

O mesmo cáso se deu com 1 femea enclausurada no dia 27 de agosto: morreu sem deixar prole. 


\section{EXPERIENCIA 16.}

Recolhendo em gaiola separada, no dia 10 de novembro de 1903, 10 femeas de Culex fatigans, a maior parte dellas apparentemente repletas de sangue humano, appareceram 8 jangadas de ovos até o dia 12 de novembro, (intervallo de dois dias). Os ovos eram ferteis; acompanhei-lhes o desenvolvimento.

Morreram as 8 femeas no mesmo dia, sobrevivendo sómente as 2 que não tinham fornecido postura até então.

\section{EXPERIENCIA 17.}

8 femeas de Culex fatigans, apanhadas em liberdade e das quaes ao menos 5 ostentavam ter chupado sangue humano, entraram em gaiola (além de 3 machos) no dia 15 de dezembro de 1903.

Appareceram 5 jangadas normaes de ovos na tarde do dia 17 de dezembro, (intervallo, $21 / 2$ dias). Ovos ferteis, observando-se o desenvolvimento das larvas. Das femeas d'esta caixa (alimento, só agua) morreu a ultima no dia 27 de dezembro (12 dias).

\section{EXPERIENCIA 18.}

7 individuos machos de Culex fatigans, criados no captiveiro, foram reunidos no dia 14 de agosto em gaiola separada e submettidos ao regimen alimenticio de MEL e agua.

Morreram os 2 primeiros machos a 20 de agosto ( 6 dias), e quanto ao ultimo individuo foi victima de uma aranha no dia 8 de outubro, tendo vivido 55 dias no captiveiro.

\section{EXPERIENCIA 19.}

Outros 7 individuos machos, criados no captiveiro, foram postos em outra gaiola, no mesmo dia 14 de agosto e tratados de modo identico.

Morreu o $10^{\circ}$ com 6 dias, em 20 de agosto, ao passo que um alcançou $\mathbf{5 3}$ dias de idade ( 6 de outubro) e o ultimo $\mathbf{5 6}$ dias ( 9 de outubro).

\section{EXPERIENCIA 20.}

8 femeas de Culex atigans, criadas no captiveiro, foram em tudo tratadas da 
mesma maneira, entrando em observação no regimen de mel e agua a 14 de agosto de 1903. Não obtive postura de ovos.

Morreram 5 femeas até o dia 20 de agosto ( 6 dias ).

Morreu 1 femea no dia 1 de setembro ( 17 dias).

$$
\begin{aligned}
& \text { " } 1 \text { " " } 6 \text { de outubro (53 dias). } \\
& \text { " } 1 \text { " } " 9 \text { de } " \text { (com } 56 \text { dias de idade no captiveiro). }
\end{aligned}
$$

\section{EXPERIENCIA $\mathbf{2 1 .}$}

Trez femeas criadas no captiveiro, em isolamento individual, entraram juntas em gaiola separada no dia 17 de novembro de 1903. Regimen mel e agua. Juntou-se-lhes mais uma femea no dia 29 de novembro.

Não appareceu postura alguma de ovos. Morreram estas femeas:

no dia 21 de dezembro, uma, com 34 dias de vida;

no dia 29 de dezembro, uma, com 42 dias de vida;

no dia 30 de dezembro, uma, com $\mathbf{4 3}$ dias de vida.

\section{EXPERIENCIA 22.}

N'uma gaiola separada foram successivamente postas:

no dia 14 de outubro 1 femea;

» 16 " outubro 4 femeas;

captiveiro.

" " 17 " 5 femeas; perfazendo um total de 10 femeas, criadas no

Foram submettidas ao regimen alimenticio de uma soluç̃o aquosa de extracto de carne de Maggi (do de tubos de gelatina).

Nao obtive postura alguma de ovos. As trez ultimas femeas alcançaram relativamente as seguintes idades: 25 dias, 29 dias, e 34 dias ( 17 de novembro de 1903 ).

Experiencias sobre o intervallo de tempo entre a ultima racáo de sangue, (provavel ou observada directamente) e a data da postura dos ovos. Resumo extrahido das annotações:

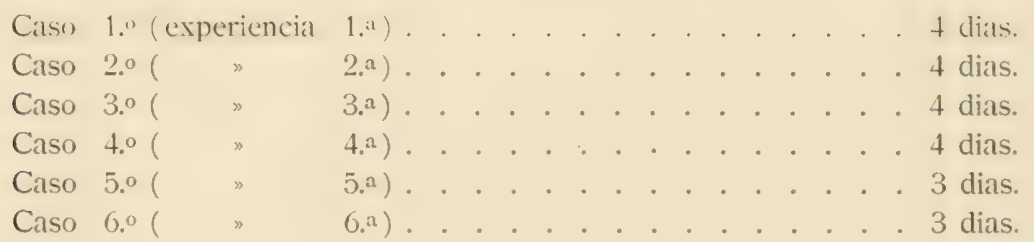




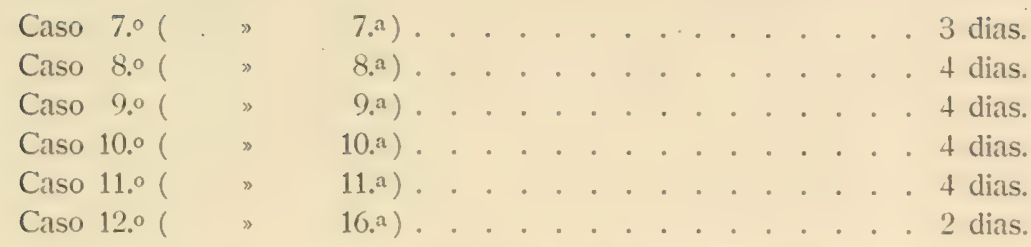

N'esta serie de 12 casos o maximo é de 4 dias ( 8 vezes), o minimo de 2 dias ( 1 vez). A média arithmetica é perto de $\mathbf{3}, \mathbf{5}$ dias $=84$ horas (sendo este resultado quasi o mesmo que no caso da Stegomyia fasciata).

Experiencias sobre a sobrevivencia das femeas de CULEX FATIGANS ao acto da postura dos ovos. Resumo:

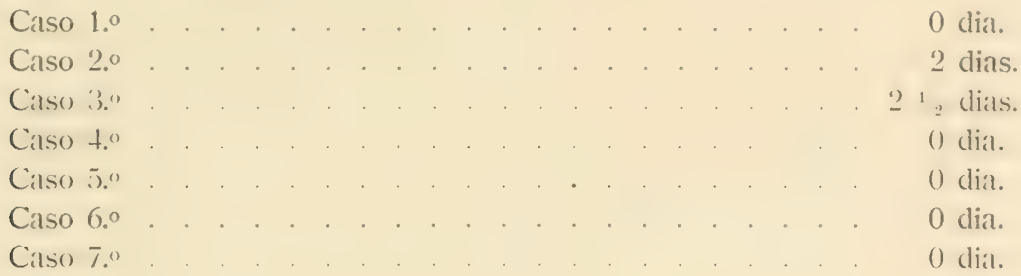

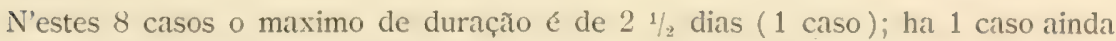
de 2 dias - ha porém 6 casos $(80 \%$ ) de morte das respectivas femeas nas horas immediatas depois do parto. Nao ha duvida que isto constitue a regra e norma na especie Culex fatigans.

Experiencias sobre o intervallo de tempo que levam as novas larvas para sahir dos ovos recem-postos. Resumo:

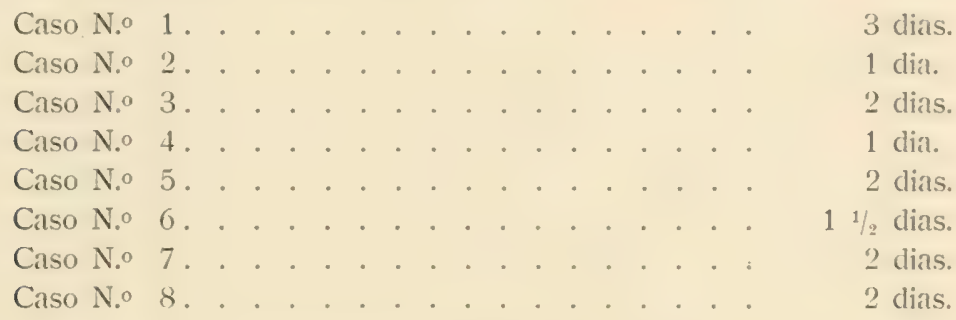

N'esta serie de 8 observações o maximo é de 3 dias ( 1 vez), o minimo de 1 dia (2 vezes). A média arithnetica é perto de 1,8 dias isto é, approximativamente 43 horas (visivelmente muito menos do que no caso dos ovos de Stegomyia fasciata). 
Experiencias sobre a duraça da vida no captiveiro debaixo da influencia da alimentaça artificial. Resumo:

Extrahi os seguintes dados das minhas notas, relativas a femeas e machos de Culex fatigans, submettidos ao regimen de mel ou de extracto de carne diluido: (1)

Femeas:

$\begin{array}{llc}\text { 1. }{ }^{\circ} \text { caso } & 25 \text { dias } & \text { (extracto de carne). } \\ 2.0 \text { caso } & 29 \text { dias } & \text { (id.) } \\ 3 . \circ \text { caso } & 34 \text { dias } & \text { (id.) } \\ 40^{\circ} \text { caso } & 34 \text { dias } & \text { (mel) } \\ 40^{\circ} \text { caso } & 42 \text { dias } & \text { (id.) } \\ 6 .{ }^{\circ} \text { caso } & 43 \text { dias } & \text { (id.) } \\ 7.0^{\circ} \text { caso } & 52 \text { dias } & \text { (id.) } \\ 8.0^{\circ} \text { caso } & \mathbf{5 6} \text { dias } & \text { (id.) }\end{array}$

Machos:

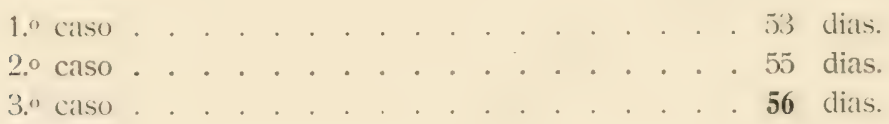

Experiencias sobre a duracão do cyclo inteiro desde a data da postura dos ozos até a sahida das imagines (mosquitos alados).

Sendo de especial interesse os casos de duração minima, tenho a declarar que observei um caso de 10 dias completos e diversos outros entre 10 e 14 dias.

\section{RESUMO DOS PRINCIPAES RESULTADOS}

\section{do acervo de experiencias enumeradas e organisadas em vista do questionario retro}

I) O mel constitue um optimo alimento sob o ponto de vista da longevidade do individuo no captiveiro, prolongando a existencia dos mosquitos em questão de um modo extraordinario. Vigora isto tanto em relação á femea, como em relação ao macho, sendo que individuos de ambos os sexos, sobretudo os do sexo masculino, o requestam com visivel avide\%.

(1) Para as femeas deixei de tomar em consideraçâo aqui os valores inferiores a 25 dias, e para os machos até todos os inferiores a 50 dias. 


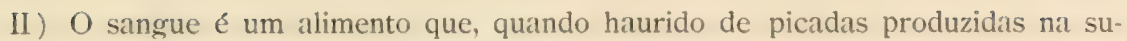
perficie do corpo de vertebrados superiores, é com insistencia e avidez procurado pelas femeas, agradando apparentemente ao seu paladar, porém prejudicial á duraçăo da vida do individuo, porque a encurta, por motivos que adiante exponho. Sángue esvasiado de outro modo, embora fresco, é regeitado ou recebido com indifferença, não só pelos machos, como pelas proprias femeas.

III) O sangue haurido é um alimento que favorece e accelera a postura dos ovos, procluzindo ná organisação reproductora da femea certeira, energica e immediata reacção, perceptivel desde a primeira ração.

IV) O mel, pelo contrario, tem, com referencia á ovulação, um effeito retardatario e interruptor, ou pelo menos neutro. O mesmo effeito exercem os liquidos assucarados e os alimentos vegetaes.

V) Temos assim na mão com as femeas de certos mosquitos no captiveiro, um modo infallivel de, ao nosso arbitrio, prolongar-lhes a vida, supprimindo a ovulação, durante longo prazo de tempo, - recorrendo á alimentação com mel, - ou de provocar prompta postura de ovos, - ministrando a alimentação com sangue.

VI) Isto é tão verdadeiro, que a faculdade de depositar ovos fecundos (em femeas previamente fecundadas) de Stegomyia fasciata, poude ser conservada latente durante 23 dias, - 26 clias, - 48 dias, - 75 dias, - 102 dias, fazendo-a explodir, por assim dizer, ao nosso bel prazer, na primeira occasião da mudança do regimen alimentar de mel para o de sangue. (Circumstancia esta que não deixa de ser interessante ainda debaixo do ponto de vista physiologico da extraordinaria vitalidade do sperma depositado no receptaculum seminis).

VII) Em outras palavras : O MEL é alimento vantajoso ao INDividu, prolongando-lhe a vida; nato merece porém a mesma qualificaça sob o ponto de vista da ESPECIE, visto que exerce effeito retardativo sobre a função reproductiva da femea.

O sangue é, pelo contrario, alimento prejudicial ao indriduo, porque lhe encurta a vida, optimo porém em relaço á ESPECiE, porque favorece a funccao reproductiva.

VIII) Temos o direito de chamar o sangue como postulato necessario e indispensavel para a postura de ovos ferteis e opinamos que, pelas experiencias acima, ficou, pela primeira vez, experimental--e materialmente provado e definitivamente liquidaclo, o que até aqui era acceito como supposição hypothetica. (1)

(1) Nuttall e Shipley, no seu importante trabalho sobre a bioloria do Anoplseles, dizem no fim de seu capitulo Cviposition", par. 65-67, acerca das experiencias de Ross, Innett, Austen (1901) e de Grassi e Ross (1001), e Annett. Dutton e Elliot (1901): : In the abowe experiments the mesquitees as a rule appear to bate only bad the cloice betacen the banana and blood. The fact that the insects did not propagate on hanana and did on blood does not prooze the blood is a the banana ama blood. The fact we can reach such a conclusion we must know more about the fond which these insects may seek in nature and on this point we have very little information. That the insects, at any rate in limited numbers, frequently have access to blood is of course clear from the mere fact that they ase necessary for the distribution of malarial frequently have access to blood is of course clear from the mere fact that they ale necessary for the distribution of malarial certaisty need exact and further studies upon the natural food of the Culicidx). "Nós podemos todavia responder: que

1) os ditos Culicidios não pờm cum alimentaçäo de banana, mas piem com sanı́sue;

2) nảo pöem com assucar e xarope. mas póem com sangue :

3) não pōem com mel, mas pöem $\mathrm{com}$ sanrue, etc. etc.; a conditio sine qua non p para a postura de nvos ferteis, cresce na proporçio do augmento numerico da serie de substancias experimentadas, sempre com resultado nezativo, decrescendo por outro lado, na marcha inversa, calda vez mais o valor ilo arcrumento coutrario. Ora, náo é nada milis do que intuitivo e loyico, que se em $1,2,3,4 \ldots n$ casos orwanisados sempre conforme um e o mesmo methodo, o resultado á 
IX) Femeas não fecundadas de Stegomyia, e criadas no captiveiro em estricto isolamento individual, acceitam facilmente sangue. Não representa portanto a copula sexual, o factor preliminar necessario para a queda das femeas ao exercicio da haemaphilia. (2)

Mas resulta tambem por outro lado das nossas experiencias, que não se póde considerar o sangue como verdadeiro alimento normal das femeas dos Culicidios haematophagos, como opinava Grassi (3) pelo menos em relação ao Anopheles. Sangue constitue no caso da Stegomyia fasciata e do Culcx fatigans, e será tambem no caso do Anopheles, o viatico, e por assim dizer, o explosivo da ovulação. (Poder-se-ia concordar com o modo de vêr de Grassi sómente no sentido de que a postura dos ovos, o deixar prole e descendencia, representa a suprema funcção vital, a principal e mais importante vocação profissional para a femea dos mosquitos, como aliás para as femeas dos insectos em geral. Debaixo d'este ponto de vista o sangue, como favorecendo a postura, poder-se-ia finalmente chamar de alimento "normal" e "regular.»)

X) Taes femeas não fecundadas de Stegomyia podem chegar a pôr ovos, porém estes não são ferteis, não fornecem larvas (Pseudo-parthenogenese).

XI) A postura sendo completa, a femea, tanto de Stegomyia como de Culex fatigans, morre nos dias immediatos, a maior partes das vezes, até em acto continuo. Costuma porém sobreviver a femea nos casos de posturas incompletas e fraccionadas, até que a somma dos ovos das posturas parciaes tenha attingido approximativamente ao numero que se póde taxar de proprio e caracteristico para cada especie.

XII ) Para que se produza o effeito de uma postura completa de ovos é preciso que a femea de Stegomyia tenha tomado diversas rações de sangue em dias successivos, no minimo 2 a 3.

Não consegui obter um resultado igualmente decisivo sobre este ponto em relação ao Culex fatigans.

XIII) O intervallo de tempo respectivamente, entre a primeira (Stegomyia),

negalizo, so passo que em $n^{1}$ outros casos, tambem serguindo um e mesmo systema, o resultado é infallivelmente posilivo a admissão da * conditiosine qua non " já nâo é mais cousa que a gente possa recusar: o nexo causal é manifesto de mais. Nuttall e Shipley, se até ayora não julgaram producentes as provas antes existentes, nâo dirão o mesmo depois d'estas minhas experiencias. O methodo estriclamente scientifico d'estas, combinado sempre com ensaios simullaneos de cotejo obedecendo a um plano cuidadosamente premedilado nos pormenores, lezarí os íalorosos autores a acceitar as vistas aqui desentolvidas e a considerar o problema como resolvido.

Quanto to processo da postura dos ovos entre os mosquitos dizem Nuttall e Shipley, no mesmo capitulo (pay. 65) yue d'elle não houve ainda testemunha ocular. com uma unica excepção (Kerchbaumer). Eu posso asseverar que desde a publicaçio do meu trabalho anterior (conf. pay. 18) náo sómente assisti o acto diversas vezes em femeas de Stemomyia, Culex, Taeniorhynchus, l’anoplites, Ianthinosoma, mas que até d'elle consegruimos tirar vistas photographicas. Tratarei d'este processo opportunamente.

De especial interesse e importancia é ainda o caso descripto na Experiencia 11." (pag. 52), onde uma femea de Stexomyia apanhada em liberdade entre 10 e 15 de novembro de 1903 e submettida ao rerimen de mel, poz ovos ferteis ainda no dia 29 de novembro - depois de um intervallo de 14 a 19 dias.

Para um investignador não muito escrupuloso seria uma forte tentação, de por ahi architectar um castello de hypotheses de que não é preciso o sangue para a postura de ovos, que o mel fez o mesmo serviço. Para mim porém, é apenas um aviso, de quanta cautella é precisa na apreciação das circumstancias exteriores antes de tirar conclusões: não vejo. como jit disse (pay. 52), n’este extranho acontecimento senāo a influencia embora tardia de alsuma raçio modica de sangrue, haurida pelo mosquito quando ainda em liberdade. Seja como fôr, fica um plsenomeno isolado e curioso este, que n'uma femea de Stegomyia o effeilo do sangue lezasse um prazo minimo de 15 dias antes de se manifestar sobre a octulacūo.

(2) Foi, ao que parece, Ficalbi qquem primeiramente pronunciou a hypothese da dependencia da haemaphilia de uma copula sexual anterior. Conf. Grassi, « Malaria o pas. 77.

(3) * Malaria * pag. 104 - Nutall e Shipley loc. cit. 70 , citam da edição italiana o trecho seguinte: * In breve si puó dire che alle femine degli Anofeli la dieta vegetale non basta e il sangue é indispensabile, ? 
e a ultima (Culex fatigans, ração de sangue e a postura de ovos foi determinado para a Stegomyia fasciata como sendo na média. 3,7 dias $=88$ 1/5 horas, e para o Culex fatigans 3,5 dias $=84$ horas.

XIV) O intervallo de tempo entre a postura dos ovos e o primeiro apparecimento de novas larvas foi achado para a Stegomyia fasciata, como sendo na média 4,5 dias, $=108$ horas; para o Cule $x$ fatigans sómente 1,8 dias $=43$ 1/5 horas.

\section{ALGUMAS CONSIDERAÇÕES FINAES}

Caracter e indole da Stegomyia fasciata. - Se ha, como é bastante provavel, sempre certa especie de mosquito perseguindo de preferencia tal ou tal animal, creio não ha entre os Culicideos casta alguma que se tenha adaptado de modo igual e tão completa e exclusivamente á perseguição do homem, na zona tropical, como a Stegomyia fasciata.

No littoral atlantico sul-americano ella agarra-se aos calcanhares do homem, por toda a parte onde este tente reunir-se em agrupamento, condensando-se as habitações em cidades um tanto maiores. É forçoso admittir que lhe serve de rehiculo o desenvolvimento da navegação a vapor, pois só assim chega-se a comprehender a sua hodierna distribuição geographica nos seus pormenores. Uma indicação valiosa fornece n'esse sentido, por exemplo, a maneira como a Stegomyia conquista pouco a pouco o valle amazonico, desviando-se por excepção da direcção do littoral e internando-se em sentido perpendicular aos contornos da costa, em longinquas regiões do interior, do sertão: Tomou pé e acampamento em Manaos, capital do visinho Estado do Amazonas, cidade, como é sabido, de moderno aspecto e rapido crescimento, a 1600 kilometros do Parí.

Ora, porque a Stegomyia não se faz sentir, como soube por informações in loco obtidas, de pessôas fidedignas de Santarém, Faro, Monte Alegre e Obidos, cidades todas bastante menos distantes? Devo suppôr que é principalmente porque são ainda pequenas demais, não querendo eu contestar, que ainda possa haver outros factores secundarios locaes que auxiliem talvez a produzir semelhante estado negativo.

Por outro lado estou plenamente convencido de que uma investigação cabal acerca da data em que a febre amarella principiou a tomar assento em Mlanáos como molestia endemica, por um lado, e uma pesquiza historica acerca do incremento da navegação a vapor, com ponto final em Manáos (dislocado hoje já consideravelmente além, para Iquitos) (1) por outro lado, viria mostrar intima e significativa relação entre os dois factos.

O grande rio-mar, com a sua direç̧ão quasi parallela ao equador, navegavel para navios transatlanticos de alto bordo, e com as suas condições climatericas optimas justamente para este mosquito eminentemente tropical, devia ser um excellente vector na marcha conquistadora da Stegomyia.

(1) Ainda đlurante a impressão d'estas provas os jornaes d'aqui, em Belém, trazem a noticia teleuraphica de terse manifestado em Iquitos o evómito neuro s, victimando por ora principalmente crianças. 
Podemos assim encarar a Stegomyia como sendo na realidade um novissimo flagello, uma peste que, qual má estrella, acompanha como inimigo occulto, na regiåo littoral neotropica, duas das mais legitimas aspirações humanas, dous dos elementos mais poderosos nas obras de progresso e civilisação-a formação e manutenção de grandes cidades, desenvolvidas por uma activa navegação a vapor.

No Pará a Stegomyia é, como já disse alhures ultimamente, frequentissima, a ponto de tornar insupportavel a existencia em certas partes da cidade, principalmente para gente que, pelos seus deveres profissionaes, se acha acorrentada á mesa de trabatho. São as horas calidas do dia, as em que ellas mais sanguinarias e insistentes se mostram. Basta ligeiramente suar no pescoço, nas orelhas, no rosto, nas mãos: ella nos perseguirá com as suas picadas com uma tenacidade e crueldade de que não encontro facilmente outro exemplo. Que a crescente insistencia nas perseguições por parte das femeas de Stegomyia acompanha de facto e corre parallelamente á crescente transpiração do nosso corpo, é uma coisa que cedo impressionará o observador attento. E' que a secreção do nosso suor tem evidentemente um papel assaz significativo na vida d'este mosquito.

Os proprios machos de Stegonyia mostram-se aggressivos durante estas horas, (1) perseguindo-nos em qualquer parte descoberta do corpo em transpiração : elles vêm haurir o suor, e se não chegam a picar, certamente não será tanto por falta de vontade, mas pela conformação não sufficientemente robusta do apparelho buccal. Nunca eu pude observar pessoalmente, nem qualquer um dos meus collegas, um macho de Stegomyia picar e chupar sangue, - embora haja autores (2) que de quando em vez fazem declarações affirmativas; tambem ainda não encontrei macho com abdomen dilatado por sangue e deixando ver este liquido por transparencia.

Mas por outro lado sei por multipla experiencia que os machos assentam tambem n'estas occasiões, e não me posso libertar da impressão de que elles conseguem pelo menos produzir uma certa commixão e irritação local, que só potencialmente differe da dolorosa sensação produzida pela picada da femea. Não chegam a perfurar a epiderme, mas chegam a irrital-a e não me surprehenderia, se estudos histologicos mais minuciosos revelassem um dia, que o apparelho venenifero não ficasse em desenvolvimento muito aquém do attingido no sexo feminino. (3) A sensação desàgradavel produzida pelos machos da Stegomyia é ainda augmentada pelo truculento zumbido, proferido em fina voz de descanto.

(1) É facto de observaçio diaria, que a reciăo occipital da cabeça principalmente, e tambem as màos de pessoas que estão recolhidas, vestidas, em rède ou cama, durante as horas calichas para, aqui na cidade, descancar ou por se acharem indispostas, são assediadas por uma nuven de talvez 10 a 15 Stegomvias, na sua maioria machos, em incessantes acharem indispostas, sio
evoluçoes serpentinas.

(2) Ficalbi conf. Theobald, Vol. I, par. 71 Mc Kay, conf. Theobald, pas: 293

(3) Recentes investigaçóes minuciosas feitas por Nuttall e Shipley, loc. cit. pas. 186 seg., acerca da anatomia do Anopheles maculipennis ensinam que o effeito venenoso e inflammatorio da picada é directamente devido í saliva das glandulas salivares, sitas no thorax, saliva expellida por um canal subtilissimo no hypopharynx.

A tumefacção lá existente, na extremidade da tromba, formada pelos dous « labellae », de feitio espatular, não entra em acçào senáo como secundario factor mechanico. 
E eis-me outra vez nas pegadas das considerações feitas nas pag. $24 \mathrm{e} \mathrm{seg.} \mathrm{do}$ meu primeiro trabalho sobre "Os mosquitos do Pará". Lá mostrei qual era, ao meu ver, o caminho phylogenetico percorrido pela haemaphilia dos Culicideos. Apontei para o serum sanguineo de escoriações, at humidade no canto dos olhos, e semelhantes secreções, tão avidamente procuradas por uma turba de Dipteros minusculos. Claro é que o suor faz parte dos mesmos productos. E eis a Stegomyia fasciata que vem corroborar ainda uma vez o acerto d'esta explicação : apegando-se esta especie ao homem, primitivamente ambos os sexos tributavam-lhe o suor. Ao passo que as femeas progrediam até a perfuracao habitual da epidermide, tornando-se chupadoras profissionaes de sangue humano, os machos conservam-se na phase anterior, historicamente mais antiga de lambedores do suor, e semelhantes secrecões do corpo humano.

Quanclo e onde ha muitas Stegomyias, nota-se que os machos, por vezes reunidos em turbas de 15,20 e mais, visiveis de um golpe de vista, costumam observar por um lado um tal ou qual espirito corporativo quanto aos seus similares, e um certo antagonismo apparente quanto ás femeas por outro lado. Manifesta-se este na circumstancia de, por exemplo, agglomerarem-se os machos a tal canto de uma meza com o seu encerado, tapete, etc., quando as femeas circulam pelo quarto, ou de se postarem em tal regiao da parte ascendente de um mosquiteiro, ao passo que as femeas voam por baixo da cama ou fazem reconhecimento voando pelas visinhanças. São atalaias, pontos sálientes de vigia e de observação, de onde os machos se atiram contra qualquer femea que thes venha transpor a area de dominio.

Em geral póde-se dizer que a Stegomyia é um mosquito singularmente photophilo : o alegre zumbido, que tanto os machos como as femeas deixilm ouvir, dançando animadamente em enxames, quando o sol da tarde dá moderadamente na sua gáiola, depõe tambem n'este sentido.

Quanto ao som produzido pelo vôo da Stegomyia fasciata, não me consta pela litteratural, que ensatios tenham sido feitos de determinal-o de modo scientificamente exacto. Fiz uma tentativa n'este sentido, auxiliado por dous collegas do Mluseu, versacios em assumptos de musica. Para este fim servimo-nos dos inquilinos das duals caixas de deposito, contendo uma sómente indivicluos do sexo masculino, outra sómente femeas. Escolheu-se uma hora clurante a tarde, expondo as gaiolas aos raios branclos do sol de um dia meio encoberto. Utilisamos uma cithara e um diapasão, de conhecido numero de vibrações.

Achamos o som da femea correspondente à c'o dó

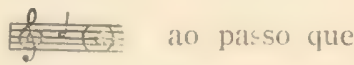
o do macho corresponde ao do li

Os clous sons estão entre si na relação de uma sexta; o $a$ do matcho corresponde a 880 vibrações, o $c$ da femea a 480 vibrações. Tanto n'um como n'outro caso tivemos a impressão de que ao lado do som principal ouvem-se, de quando em vez, simultaneatmente as respectivas oitavas, de maneira que o timbre parecia encoberto pelos competentes sons concomitantes ( Obertöne» da linguagem technico-acustica allemã). 
Evidentemente exercem certo effeito sobre altura e timbre do som o estado de maior ou menor dilatação do abdomen com alimento e quem sabe até o effeito psychico debaixo da influencia da suggestão mutua.

Não deixa de ser interessante a semelhança n'este nosso resultado obtido em referencia á Stegomyia com o de Nuttall e Shipley acerca do Anopheles maculipennis ( Structure and biology of Anopheles", Journal of Hygiene, Vol. I1, N.o 1, jan. 1902, Cambridge, pag. 78 seg. ).

(Coincide o tom dos machos, com 880 vibrações; para femeas mais ou menos vasias comtudo o som parecia-lhes mover-se ao redor de $c$ inferior (dó grave) com 240 vibrações, portanto uma oitava mais baixo).

Em relaça á copula sexual da Stegomyia, que parece ter sido ainda muito pouco observada a julgar pelas pauperrimas indicações na litteratura e que só muito recentemente foi tratada por um autor residente na ilha da Trindade, conforme se vê pelo Vol. III da Mlonographia de Theobald (1903, pag. 143) temol-a risto milhares de rezes e a vêmos todos os dias, sem que todavia nos fôsse possivel descrevel-a de modo plenamente satisfactorio nos seus menores detalhes. O processo nos seus contornos geraes é este: um macho precipita-se da sua atalaia sobre uma femea que se approxima vôando, une-se a ella pelo lado inferior, e deixa-se por ella levar n'um vôo lento e pesado durante uns poucos segundos (2 ou 3 sómente), depois separam-se de novo. E' obra de um momento, e surprehende realmente a ligeireza com que este acto se consumma e a facilidade com que os dous nubentes se safam do amplexo sexual. A scena é um vivo contraste com o que se vê por exemplo na mosca domesticá e outros Dipteros, e tãofugaz, que difficilmente a gente consegue dar conta, e todas as tentativas que até agora fizemos de fixar um casal no acto da copula por um meio subito de morte, abortaram invariavelmente, a menos que a gente não recorra ao meio extremo do achatamento e esmagamento entre as duas mãos, o que naturalmente não fornece um resultado aproveitavel para o reconhecimento do situs. Por outro lado, a Stegomyia precisa de tão pouco espaço para o seu vôo nupcial, que este se póde operar sem difficuldade até dentro dás estreitas dimensões de um boccal ou de uma gaiola de criação, - facto este que facilita consideravelmente a fecundação de femeas criadas no captiveiro e com isto a criação d'esta especie de mosquito durante gerações consecutivas.

Tanto quanto é possivel julgar sem marcação préria dos individuos por qualquer signal especial, parecia-nos que o mesmo macho executava diversas copulas em rapida successão com diversas femeas que se approximaram.

Todo o processo da copula da Stegomyia tem, como se vê, muita semelhança com o que já esbocei para o Culex fatigans em publicação anterior (pag. 25, 26). Se aqui nestas bacchanaes não chegam a formar-se aquellas duas nurens distinctas, dançándo no ar, constituidas, uma por machos só, outras por femeas só, todaria fica de pé certa tendencia separatista, certo antagonismo local, ao qual alludi acima. Támbem no Culex fatigans a copula dura sómente obra de um momento. Mas quer me parecer que o Culex fatigans assim mesmo precisa de mais espaço para o seu vôo nupcial, 
faz maiores exigencias do que a Stegomyia, não se realisando a fecundaçào no captiveiro com a mesma facilidade e quasi certeza mathematica como no caso d'aquella.

Tenho a impressão de que, em geral, o Culex fatigans, comporta-se de modo mais rebelde, obstinado, teimoso, refractario a domesticação e comprehensão: significativa prova d'isto julgo poder perceber na circumstancia singular, que em caso algum consegui fazer, no captiveiro, chupar sangue um unico idividuo sequer d'esta especie de mosquitos, nem entre os apanhados no estado de liberdade, nem entre os criados no captiveiro. Reputo-o de um gráo de intelligencia decididamente inferior á Stegomyia fasciata. E se vou bem acertado com o meu sentimento natural de que, da mesma maneira como nos outros insectos hatematophagos, tal especie de Culicideo acha-se principalmente relacionado com certa e determinada especie de vertebrados-hospede, sinto-me induzido a dizer que tenho o Culex fatigans por um mosquito primitivamente adjudicado menos i especie humana, com especialidade, do que a certos animaes domesticos e, entre estes, minha suspeição aponta principalmente para os inquilinos dos nossos gallinheiros. E não seria possivel que na sensivel diversidade intellectual entre Culex fatigans, e Stegomyia fasciata reflectisse ainda a primitiva diversidade entre os seus respectivos hospedes? Estou certo, e ninguem me contestará, que é preciso ser mosquito mais experto para perseguir o homem, do que para perseguir gallinhas, ou gato ou cão que seja. E não estão aqui os ratos e morganhos domesticos e, entre os insectos, as odientas baratas a provar de quanto vale o effeito da convivencia diaria com o "homo sapiens" no sentido do desenvolvimento e do refinamento intellectuaes?

Seja como fôr, não ha que duvidar de que, tanto a Stegomyia fasciata, como o Culex fatigans, são dous Culicideos hoje, que, intrusos malignos, pertencem á bagagem, ao inventario dos parasitas, pestes e flagellos animaes que se apegam ao calcanhar do homem na zona littoral neotropica! (1)

Pouco ou nada foi ventilada até hoje a questão da origene e proveniencia da Stegomyia fasciata. Não hesito em confessar que julgo-a de origem africana. E baseio-me principalmente n'uma consideração critica da actual distribuição geographica do genero Stegomyia.

Tanto quanto se póde julgar pela Monographia de Theobald, é um genero natural, composto todo de especies que no seu especto, rajado de preto e branco, possuem um traço caracteristico que á primeira vista logo tríe affinidade e parentesco. Na

(1) Até que ponto os moxquitos podem tornar-se um flayello em certas regiōes, cita-nos Felix Lynch Arribalzagra. conceituado dipterologista arurentino o secuinte edificante trecho: * En los climas húmidos y cálidos, son un verdadero azote, hasta el punto de hacer casi inhabitables ciertas comarcas; seoún Spix y llartius, en las márgenes del Amazonas, del Urinoco y del Yapure, hacen tan dolorosa la existencia de los pobres indigenas que, las delicias de la vida futura anunciadas por los misioneros, se las imaginan como el término de las penalidades á que los sujetan los abundantisimos mosquitos de esas recriones s. Dipterologria Argentina, 1901, pay. 24). - Aliás ć de suppòr que aqui entram em consideraçào mosquitos de outros generos como Anopheles, Panoplites, Taeniorhynchus, etc. 
dita obra, com o seu recentissimo tomo supplementar (III), encontro como correspondendo ao actual estado scientifico um total de 21 especies. D'estas, nada menos de 11 especies (mais da metade) são indigenas da Africa (Serra Leôa, Nigeria, Senegambia, Nubia, Mashonalandia ): S. fasciati, S. sugens, S. nigeria, S. africana, S. grantii, S. marshallii, S. argenteopunctata, S. minuta, S. irritans, S. nigricephala, S. albocephala.

A' Asia pertencem: Stegomyia scutellaris, S. pseudo-taeniata, S. gubernatoris, S. crassipes, S. pipersalata, S. nivea -6 especies ao todo (não incluindo a ubiquistica Steg. fasciata), menos do que ${ }^{1 / 3}$ do total.

A' Australia cabe a St. notoscripta (não incluindo outra ve\% a infallivel St. fascial( (1).

Do continente americano, de Norte a Sul, Theobald enumera ainda S. signifor, Columbia (E. U.), S. terrens (habitat incerto), S. sexlineata (Trindade), transparecendo comtudo duvidas acerca da posição systematica, pelo menos em relação ás duas primeiras.

A especie de mais arantajadas dimensões parece ser a St. grantii da ilha de Sokotora (Africa oriental).

Ora, não fazemos outra cousa senão empregar uma regra fundamental de investigação biologica moderna, se procuramos pelo menos quanto ao conjuncto organico actual, patria e ponto de disseminação e irradiação de fórmas pertencentes a um e mesmo grupo natural de plantas ou de animaes, lá onde convergem os fios do maximum numerico de especies e onde encontramos as maiores e mais vigorosas fórmas. Debaixo d'este duplo aspecto do quesito, é a Africa que, obedecendo ao exorcismo de uma formula scientifica, surge diante dos nossos olhos como origem e patria provavel de todo o genero Stegomyia, e portanto tambem da malefica Stegomyia fasciata. E porque não seria assim? Que argumento serio e inderrocavel poderia ser opposto a esta hypothese?

A Stegomyia fasciata nos terá vindo da costa d'Africa bem cedo, talvez já nos tempos coloniaes, em navios de véla. Ella nos terá vindo pelo mesmo caminho, pelo qual tantos ento - e ecto-parasitas humanos e vectores de doenças celebraram a sua entràda no Brazil ( haja vista ao "bicho do pé», (1) á filaria, etc. ), - ella representa ao meu ver mais um - e não o menos importante - d'estes presentes fataes e lamentaveis, que vicram na bagagem do trafico de escravos africanos.

Seria uma tarefa tão grata como interessante e meritoria, para um escriptor medico, do paiz, lançar uma vez um arrolamento d'este funesto inventario de molestias que o continente negro nos legou!

A Stegomyia encetou a sua circumnaregação em narios de réla, nos bons tem-

(1) E' versâo corriqueira qque o bicho do pé " foi introduzido, em setembro de 1872 . na costa d'. lirica (Ambriz) por um navio inglez. vindo do Brazil. Entretanto hoje, se sabe pela chronica pouco conhecicli e recentemente publicada de novo do medico suisso sebastian Braun, de Basiléa, que. em serviço hollande\%, viajou entre 1610 - 1620 no entio reino do Congo e grande extensio do littoral atlantico que n'aquelle tempo e n'aquella bacia fluvial já lavravia entre os indigenas e a tripulaçion do navio uma molestia ecto-parasitaria chamada "Peysy » a qual facilmente se reconhece como identica á pragra do bicho do pé (Sarcopsylla penetrans L.). Jí existia portanto ni costa d'Africa a pulara penetrante uns 250 para 300 annos bem contados, antes da tal reinfecço secundaria, via 13razil, (que nào queremos pòr em duvida) datando dos nossos dias. (Veja-se a esse respeito a circumstanciada discussáo do Dr. Georg lJenning em a Verhandlun:zen der Naturforschenden (iesellschaft s in Basel, Vol. XIII. Ileft 1. 19x), pas. 227 seg.) (12 III. 19n5.) 
pos idos; hoje ella já viaja em vapor e em estrada de ferro. Aprendeu - aperfeiçoou-se. - modernisou-se.

Emboral o genero Culex tenha os seus emissarios em todas as zonas e todas as partes do mundo, sendo por isto bastante mais complicado o problema de precisar o seu centro de dispersão, tenho motivos para acreditar que justamente no caso do Culex $f(t-$ tigans as cousas não se passaram de modo muito diverso do da Stegomyia fasciata. Os mappas de distribuc ção geographica, organisados para ambos por Theobald (Stegomyia: Vol. I pag. 292; Culex fatigans: Vol. II, pag. 15j) mostram uma surprehendente concordancia.

O Culex fatigans é aqui como por toda a parte, o fiel vassallo e companheiro inseparavel da felina Stegomyia fasciata: encarrega-se de submetter a supplicio o homem e os seus animaes domesticos durante a noite, quando as creaturas precisavam do repouso restaurador, depois que a outra os assediara sem treguá, com revoltante cynismo durante todo o dia. Quando o estudo das molestias tiver um dia alcançado no futuro um grau mais elevacio ce perfeição, virá - estou prevendo isto nitidamente - a hora em que a obra collectival d'estes dous intrusos será reconhecida e avaliada devidamente em todo o seu alcance malefico e visto será, se tenho ou não razão dizendo-que í sua influencia collectiva deve ser attribuida uma das principaes causas da anemia tropical, além do quinhão de molestias graves, de que cada um d'estes dous Culicideos se faz portacur de monopolio e transmissor plenipotenciario.

Muitas vezes tenho occasião de observar, tanto na especie Stogom yia fasciata, como na especie Culex fatigans, ao lado de individuos de estatura normal, individuos mito menorcs, verdadeiros anjes. Esta obseriação póde-se fazer em especimens apanhados em liberdace, como nos criados no captiveiro, sendo que n'está ultima conjunctura o caso se repete com consideravel frequencia. Nascem por vezes individuos não sómente do sexo masculino, como até femeas, de dimensões tão mirradas, que com facilidade se safam atravez da téla de arame de malhas ainda bastante mais estreitas que a tal "tela de Grassi ", que hoje se produz em largá escala na Italia com vistas á prophylaxia contra o Anopheles e a malaria (Grassi mesmo recommendou tela, da qual colibessem não menos de 9 malhas sobre $1 \frac{1}{\mathrm{c}^{\mathrm{m}}}$ de distancia o que corresponde a pcquenos quadrados lineares de $1,7^{\mathrm{mm}}$ de lado. (Grassi, Malaria, pag. 206, Est. VII).

O Governo Estadoal do Pará importou, para ensaios, com o mesmo nome, dá Italia, uma téla onde cabem sómente 6 malhas sobre $1 \frac{1}{\mathrm{~cm}}$ de extensão linear, o que corresponde a quadrados de $2,5 \mathrm{~mm}$ de lado. Refiro-me sobretudo a esta ultima marcal, que julgo sufficiente, por via de regra, para impedir a invasão de mosquitos de fóra para dentro, na applicação a hospitaes, que reconheci porém insufficientes como revestimento parietal das minhas gaiolas destinadas a experiencias sobre mosquitos como a Stegomyia fasciata e Culex fatigans, etc., no captiveiro.

Em geral os phenomenos da macrosomia e da microsomia entre plantas e animaes estão relacionados, em primeira linha, com a nutrição mais ou menos abundante e não creio que a mencionada raça ana de Stegromyia e de Culex se explique de modo diverso do que por uma alimentaç̃o parca e um desenvolvimento demorado du- 
rante a phase larval. N'este sentido disponho até de provas experimentaes: larvas criadas em agua limpa, isto é, relativamente pobre em substancias assimilaveis, fornecem imagines de pequena estatura. Trata-se entretanto de saber se não me engano com a minha opinião de que a frequencia de individuos da raça anã, apanhados em liberdade, augmenta $\mathrm{em}$ certos periodos singularmente, assumindo caracter de uma regra. Ainda este anno, nas ultimas semanas de outubro e novembro, antes de entrar francamente a estação chuvosa, ganhei a impressão de que as femeas de raça miuda fossem particularmente numerosas. Desconfio que isto não é obra de mero accaso: é bem possivel que a frequencia de individuos de raça ana, normalmente possivel durante todo o anno, seja periodica e represente um caso, algo empallidecido, d'aquillo que se chama " $D i$ morphismo das estatões na entomologia. Theoricamente não póde haver serio obstaculo para acceitar o argumento de que no auge da estação secca, com al crescente falta de agua, as condições de existencia para as larvas tornam-se mais difficeis, favorecendo assim uma geração de mosquitos de estatura abaixo da media. Agua minguada e alimentaçăo reduzida podem, realmente, como acima vimos, obrigar a larva a gastar o dobro e o triplo do tempo normalmente preciso para adquirir o crescimento necessario para a sua metamorphose. Tenho o sentimento de que a hibernas ão, no sentido como este termo é acceito na litteratura zoologica, (passagem de uma fórma animal de uma época apropriada para a suá existencia atravez de um periodo inclemente e improprio, graças a uma reducção mais ou menos consideravel da energia das funcções physiologicas, até á volta de outra época benigna e propicia) póde muito bem. para Culicideos eminentemente tropicaes e equatoriaes, encontrar a sua expressão na dupla facies: 1) desenvolvimento demorado das larvas; 2) estatura pequena, anã das imagines. Aliás seria ingenuo pensar-se para o clima do Pará ou do Rio de Janeiro, por exemplo, n'uma repetição de hibernação propriamente dita, como esta se manifesta em estreita adaptação ao inverno neroso e glacial na latitude da Europa central e septentrional. Nas ha para a hibernação dos climas frios um equivalente e "pendant» meridional e tropical: é o phenomeno da lethargia estival, semelhante nos seus effeitos physiologicos. Será, açui no caso vertente, questão de mero gosto o emprego de um termo ou de outro, visto o seu caracter complementar e representativo. O que é bastante plausivel é que, mesmo debaixo do clima tropical, a successão das gerações de mosquitos durante o anno não seja um "motu-continuo", de actos e intervallos mathematicamente iguales e equivalentes; forçosamente haverí épocas de energia vital diminuida, revezando com épocas de actividade mais accentuada.

Ninguem irá ao ponto de attribuir-nos a supposição, para uma cidade littoral, sita entre o Pará até o Rio e Santos, da existencia de um tempo de absoluto armisticio pela impossibilidade climaterica de desenvolvimento, de larvas de Stegomyia: larvas ha e haverá durante todo o anno. Mas que a curva d'este desenvolvimento, uma vez que o estado da sciencia n'este paiz permitta a tentativa de proceder-se á representação graphica, mostrarí seus altos e seus baixos, trahindo uns e outros uma certa periodicidade, coincidindo está por sua vez com o cyclo de estações quentes e chuvosas por um lado e frias e seccas por outro lado, d'isto estou plenamente convencido e investigações pacientes e amorosas sobre a biologia dos nossos mosquitos em liberdade hão de trazer 
a confirmação cabal. Taes pesquizas revestiriam naturalmente ainda particular importancia em vista do parallelismo na periodicidade de febre amarella.

Seria erronea a opinião de que estes individuos da raça anã de Stegomyia fossem talvez menos aggressivos e sanguinarios que os de estatura normal. Comportam-se em tudo igualmente; as suas picadas não são menos dolorosas, como tive occasiño de verificar.

Longe tạbem de estar sufficientemente esclarecida é a questão da proporcâo mumerica entre os dous sexos. Prestei alguma attenção a este problema, mas o que posso adduzir até agora, não é senão uma mui modesta contribuição á sua solução.

Em agosto de 1903 retirei, de uma fossa de banheiro, grande quantidade de larvas de Culex fatigans que alli se criaram e conteia-as. Desenvolveram-se 63 femeas e 77 machos, havendo assim um ligeiro excesso de individuos do sexo masculino.

De uma consideravel criação de Stegomyia fasciata, installada em novembro de 1903, saíram até esta data (7 de janeiro de 1904): 50 femeas e 56 machos, dando-se novamente um pequeno excesso a favor dos machos.

Em diversos outros casos ainda de criação de especies de mosquitos sylvestres parecia-me ás rezes haver mais machos, em outros mais fcmeas, geralmente porém estabeleceu-se um quasi equilibrio numerico no fim da serie. E cheguei a concluir: maior a serie - melhor o equilibrio. Concordo assim com Nuttall e Shipley, que dizem: "The proportion of males to females has always appeared to us to be fairly equal and we have counted the sexes on several occasions". (Loc. cit. pag. 58).

Em relação á questão, se ha proterandria ou proterogymia ou sahida simmltanea das imagines de ambosos sexos, certas observações minhas fazem-me, por rezes inclinar a acceitar a opinião de Rees (Nuttall e Shipley, loc. cit., pag. 68) que escrereu: "When mosquitoes are bred in captivity, the males, as a rule, hatch out first ". Pelo menos lembro-me de occasiões onde, em criações de Culex fatigans, Trichuprosopun nivipes, Limatus Durhami, etc., a predominancia dos machos entre as primeiras imagines que saíam chegou a impressionar-me e fazer-me crer existir uma tendencia para a proterandria. (1)

N'uma criação de larvas de data igual e perfeita igualdade das outras condições de existencia, isto é, achando-se reunidas no mesmo boccal, a experiencia pratica ensina a conhecer em muitos casos o sexo já no estado larval. As larvas que fornecerão imagines do sexo feminino distinguem-se depressa pelo seu tamanho e calibre, correndo na dianteira, no seu desenvolvimento. Cannibalismo e parricidio estão na ordem do dia, mesmo entre as larvas saidas dos ovos de uma e mesma postura.

(1) IIoward ( Notes on the mosquitoes of the Unitel States 1900) pag. 20, refere-se a experiencias com Culex pungens (fatigans) nos seguintes temos: "The individnals emerging on the first day were invariably males. (On the secund day the great majority were males, but there were
hold for three days; later the femmles uere in majority 
As experiencias relativas á longevidade das inagines de outros mosquitos indigenas, além da Stegonyia fasciata e do Culex fatigans não deram, no laboratorio, de longe resultados tão favorave.s. E' que sómente estes dous são ierdadeiramente domesticos aqui; a maioria dos outros são cAMPESTREs e SYLITESTRES, entre os quaes sómente alguns vêm frequentar as habitações humanas para picar. As primeiras duas especies vivem, por ass:m dizer, dentro; todo o resto vive lá fóra, nascendo e morrendo ao ar livre. Julgo dever procurar a explicação da relativa fragilidade das imagines do grosso dos mosquitos campestres e sylvestres, surprehendente justamente nos generos gigantescos como Megarhinus, Sabethes, etc., pela falta cie ar e humidade, que forçosamente interfere como obstaculo á conservação no laboratorio. Condições de existencia de todo iguacs e identicas a essas que existem na natureza, claro é que quasi não ha possibilidacle de as crear e offerecer no captireiro.

Relativamente rijos achei ainda o Culex confirmatus e o Culex serratus, mas dentro do prazo de uma para duas semanas morre por via de regra quasi tudo. Encontro no meu caderno de notas, como facto excepcional. o caso de uma femea de Taeniorlynachus Arribalagage que morreu com 38 dias de captiveiro, (tendo fornecislo uma postura de 38 ovos no dia anterior). O Trichoprosopon nivipes aguenta ás vezes; o Dr. Lutz refere casos de ter conservado individuos durante 2 mezes ("Waldmosquitos", pag. 289). - No trabalho extenso conto tratar d'este assumpto, dando pormenores sobre as m.nhas experiencias.

Um caso, que demonstra ao mesmo tempo a relativa facilidade com a qual uma praga póde ser disseminada de um continente para outro e a incrivel resistencia que a Stegomyia fasciata põe em campo, quando se trata de vencer condições e circumstancias desfavoraveis da rida nos conta o Dr. F. V. Theobald, no recente volume supplementar da Mlonographia sobre os Culicidios (II, pag. $143 \mathrm{seg}$.): Recebeu o eminente especialista ovos de Stegomyia, enviados de Cuba pelo Dr. Finlay, n'um tubo de vidro em estado secco. Lí permaneceram uns 2 mezes no mesmo estado secco, na Inglaterra. Movido pela curiosidade o Snr. Theobald, resolveu um dia fazer um ensaio de criação com agua tepida n'uma estufa. Qual não foi a sua surpreza, vendo sahir as larvas em 24 horas! A maioria viveu atté 10 dias, 6 alcançaram a phase de pupa depo is de 3 semanas. Sahiram uma femea de apparencia normal, e 5 machos.

Como se vê pelo questionario acimı, entrou a questão, se havia differenças quanto î proveniencia e qualidale do sangue, isto é, se havia taliez um sangue preferido por um lado, ou um sangue optimo sob o ponto de vistal da ovulação, por outro.

Quanto á Stegomyia fasciata nunca me pude furtar á convicção de que o sangue humano não é sómente preferido a sangue de cobaya, mas tambem mais eff caz e substancial sob o ponto de vista de ovulação.

Sangue de um reptil, um saurio, lagarto (Tropidurus torquatus) com o qual experimentei, não quizeram acceitar.

E' um assumpto que ainda está muito longe de estar sufficientemente estudado. Grassi ("Malaria », pag. 105) opinava, no caso do Anopheles, que sem haver vertebrados 
de sangue quente propriamente preferidos todavia os maiores eram mais perseguidos do que os menores, - portanto mera preferencia de tamanho.

Durante o anno passado surgiram de repente na imprensa (1) noticias muito elogiativas sobre o maravilhoso effeito de uma especie de planta do genero Ocymum, O. viride para afugentar os mosquitos na Nigeria (Africa). Ora nós possuimos no Brazil um representante d'este genero no conhecidissimo "mangericão", O. minimum, mimosa herva em fórma de arbusto añ̃o, bemquisto pela facilidade com que péga, como pelo seu agradavel aroma. Fizemos experiencias n'este Nuseu e nas residencias particulares, mas de effeito benefico contra a Stegomyia e o Culex fatigans - nem sombra. Aliás outro resultado não esperavamos.

Quasi ao mesmo tempo um boato semelhante circulara, attribuindo virtudes de impedir a aproximação dos mosquitos ao nosso manoeiro (Carica papaya), (2) conforme observações feitas na China. Tambem a repetição d'esta experiencia forneceu-nos resultados negativos, quanto a Stegomyia.

Não quero perder a occasião de registrar ainda umas observações que fiz e que bem caracterisam a excessiva tenacidade e força de resistencia que a Stegomyia fasciata oppõe a certos meios que infallivelmente affastariam qualquer outra especie de mosquito.

Uma serie d'ellas liga-se a effeito nullo de uma forte correntesa de ar, produzido por vento encanado entre duas janellas abertas e orientadas no sentido do vento reinante ou pela movimentação aérea na directa proximidade de um ventilador mechanico, electrico ou outro. Pois as Stegomyias absolutamente não se importam de tal viração, continuando as suas evoluções serpentinas ao redor de nós investindo e picando, da mesma fórma, como se nada houresse de incommodativo. Não conheço outra especie de culicideo que se comporte do mesmo modo refractario em identicas circumstancias!

Outra serie de observações prende-se ao effeito não menos negativo de fortes cheiros, produzidos por exemplo por certos desinfectantes sobre o bem estar das imagines de Stegomyia. Pois n'um quarto com o chão alagado e ensopado de creolina por exemplo a gente esperaria vêr darem tregua as felinas Stegomvias. Completo engano! As emanações da creolina parecem incommodal-as tảo pouco, como se fosse um qualquer perfume. Um quarto de hora depois de desinfectado um aposento com creolina, circumrolitam lá dentro estes teimosissimos carapanãs outra rez, como se nada houvesse.

Nem um armisticio passageiro assim se consegue. Para subjugar efficazmente as Stegomyias é preciso já ingrediente mais energico, dioxydo de enxofre, chloro ou então muita fumaça de pyrethro.

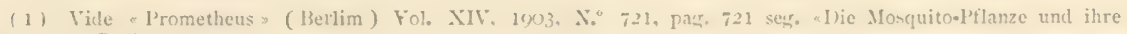
lerwandten $=$ von C. Siterne.

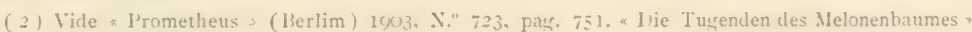


A Stegonnyia fasciata pica de noite? Eis ahi uma questão que me intrigou bastante $\mathrm{e}$, se hoje respondo affirmativamente, confesso que tive de vencer o meu proprio scepticismo e custou um esforço, não pequeno, de reunir as provas sufficientes para afastar as minhas duvidas. A resposta não era tão facil como parece á primeira vista, pois tratava-se de saber se a Stegomyia, de motu proprio, picava, em estado de liberdade, durante a noite. Hoje estou de posse do conhecimento de mais ou menos 2 a 3 duzias de casos observados $\mathrm{em}$ mim e por mim, casos estes todos perfeitamente averiguados, porque o referido mosquito, apanhado em flagrante, foi cada vez examinado e identificado por mim pessoalmente. (Digo isto, porque da circumstancia de uma identificação scientifica depende a competencia para intervir na discussão. Este é um terreno onde sómente poderá discutir com vantagem, quem realmente dispuzer de observaçũes pessoaes). Dous ou tres destes casos deram-se no Rio de Janeiro, na Ladeira do Ascurra, na subida para o Corcovado, durante os mezes de novembro de 1902 a março de 1903; os outros aqui no Parí, no Museu e nas suas dependencias. O ultimo ainda se deu, ha poucos dias, na residencia do nosso collega, Dr. Jacques Huber, chefe da secção botanica.

Aqui no Pará todos elles deram-se mais ou menos da mesma maneira: escrevendo eu, - entre 8 e 11 horas da noite - na sala da minha residencia, ou no meu gabinete no Nuseu, com luz electrica e de janellas abertas, apanhei os mosquitos que vieram sentar nas minhas mãos, picando e chupando sangue. Geralmente os que vêm n'estas horas, entrando com certeza de fóra, pela janella, são o Tacniorhynchus fasciolatus e o Panoplites titillans. Mas de vez em quando, não sem cada vez constituir para mim assumpto de certa surpreza, lá se apresenta tambem uma femea de Stegonvia fasciata. No Rio de Janeiro as picadas nocturnas de Stegomyia por mim pessoalmente observadas deram-se no gabinete da bibliotheca, andar inferior, illuminado a gaz, nas mesmas horas; o aposento era forrado de papel escuro. Sempre notei, de dia, que eu era relativamente mais perseguido pelo mosquito rajado n'aquelle local do que em outra parte. Bem depressa consegui descobrir que de facto, nas molduras escuras dos armarios, em cima, por baixo e por detraz d'estes eram os esconderijos predilectos de bom numero de Stegomyias). Que as femeas de Stegomyia presas no captireiro, acceitaram facilmente sangue de noite, eu sabia por experiencias; pensava, porém, que isto talvez sómente se desse como anomalia de laboratorio.

A femea te Stegonyia, em liberdade, pica de noite, (1) mas concordo com esta sentença sómente com uma dupla restriç̧ão: 1) não é a regra, é uma excepção e até bastante rara, pois sobre 100 que picam de dia espontaneamente talvez uma sómente faça o mesmo de noite; 2) picam sómente com luz, - não picam na escuridão completa. A fraca luz de uma lamparina n'um quarto de dormir talvez á seja sufficiente.

Para mim isto não esfraquece de modo algum a nossa affirmação anterior, que a Stegomyia fasciata é um mosquito essencialmente diurno. A fome poderá levar alguma femea, trasmalhada, que durante o dia não tivesse tido occasião de arranjar a

(1) No recente volume supplementar da Nonouraphia de Theobald, encontro (pag. 142) um trecho de uma carta, na qual um Lr. Low refere-se is suas impressies sobre o mosquito Stegomvia na ilha da Trindacle: $* . . . . . .$. and again, as Gray says, bites all nivht as well s. again, as Gray says, bites all night as well s.

Na ilha da Trindade a Stegomyia se comportaria de modo diverso? Emquanto não houver averiguaçoes mais apro* fundadas a este respeito, sou tentado a suppôr que na expressão acima se intruduzisse talvez uma certa generalisaçâo precipitada, 
sua ração de sangue, a prolongar a sua caça até horas adiantadas, sobretudo quando estimulada, favorecida e guiada por um fóco luminoso n'um quarto.

Ora, ha no poro quem diga, que para se livrar das perseguições de mosquitos n'um quarto, não é preciso mais do que apagar a luz. Este conselho popular, - se elle não allude simplesmente ao facto de que o organismo são, cansado na labutação do dia, mais facilmente cahirá no somno n'um quarto escuro, parece que visa a Stegomyia fasciata, pois em relação ao Culex fatigans, ao Anopheles, etc. garanto que não se verificará a promettida efficacia.

Mas ha ainda uma possibilidade: quem sabe se estas femeas de Stegomyia caçando sangue em extemporaneas horas nocturnas, não são ellas mesmas victimas de uma anomalia, e não estão agindo debaixo de um qualquer impulso morbiclo, talvez constrangidas por um parasita? E quem sabe se por ahi não se esconde qualquer relação secreta com a natureza do causador da febre amarella?

Ha duas cousas bastante importantes para ficar a gente pensativa: 1) uma é a positiva raridade de casos sufficientemente averiguados de picadas expontaneas nocturnas de Stegonyia; 2 ) a tão fallada circumstancia da immunidade dos "diarios de Petropolis", no Rio de Janeiro. Haveria ainda entre estas duas cousas um mysterioso nexo causal? Lias esta pergunta abre um novo horizonte tão complexo de considerandos e argumentos, que despertam em mim a resolução de fazer disto antes o assumpto dé um ulterior artigo especial.

E, finalisando, volto ainda um momento a encarar as consequencias que sob o ponto de vista sanitario resultam do acervo das minhas recentes experiencias sobre certos problemas em controversia, da biologia dos nossos principaes mosquitos domesticos.

Imagine-se uma femea de Stegomyia, que no porto de uma das nossas cidades littoraes, onde a febre amarella ficou endemica, alcança, em estado de liberdade e previamente fecundada, como por via de regra sempre acontecerá á vista das nossos experiencias, um vapor ancorado, que carregue por exemplo assucar nos seus porões. Lá introduz-se o mosquito femea, que embora fechem o porão, com o melado que destilla dos saccos (que se acham n'aquelle estado de aspecto inolvidarel para quem jamais atravessou os quarteirð̃es commerciaes de Pernambuco, Maceió, Bahia e outros portos nortistas) se sustenta e vive perfeitamente. Supponhamos o caso extremo, que aliás não se dará facilmente, que o respectivo vapor, fazendo-se ao largo, leve 75, 100 dias mesmo, sempre navegando em mares da zona tropical, antes de chegar ao porto de destino, em outro continente, seja da Africa, da Asia, do Norte da Austraiia. Abre-se o porão, sáe o mosquito, tem occasião de picar e chupar sangue. E não ficou experimentalmente provado por nós que tal Stegomyia femea ainda pode estar perfeitamente habilitada a pôr os seus ovos, fecundos mesmo, depois de tão extraordinario lapso de tempo, disseminando assim a especie em terras longinquas, talvez antes por ella não habitadas? Não demonstramos acima, de modo inconcusso, a capacidade da Stegomyia, de prolongar, por um lado, a sua existencia individual com tal alimentação quasi illimitadamente, para por outro lado sacrifical-a logo na primeira occasiào, nas aras do interesse da especie, pela primeira ração de sangue? - E não abre esta capacidade até ampla margem, para 
substituir na organisação acima o rapido meio de transporte a vapor, de hoje, pelo rá. garoso, caprichoso, incerto e incommensuravel transporte em navio de vela dos tempos antigos? Que objecção de algum valor contra a minha explicação acerca da origem e proveniencia africana da Stegomyia fasciata pelo trafico de escravos poclerão ainda levantar e que ficticia barricada de argumentos contrarios accumularão ainda ante a vista intellectual para a não comprehensão do significativo phenomeno real e facticio da moderna entrada d'este mosquito em Manáos, a 1300 kilometros (linha do ar) da foz do Amazonas, servindo-lhe de vehiculo o crescente incremento da navegação a vapor?

Poderia haver quem, concordando commigo nos seus considerandos até aqui, todavia retrucasse, que no caso imaginario acima desenvolvido, não fosse enrolvida, como consequencia logicamente necessaria, a faculdade da femea de Stegomyia em questão servir de transmissor da febre amarella de um porto para outro, allegando que ficaria primeiramente a provar ainda experimentalmente a capacidade da Stegomyia femea, de conservar latente, durante tão dilatado periodo de tempo, a virulencia do germen a inocular no acto da picada.

Confesso, que quem assim falla, põe o dedo em cima de um ponto fraco e dolorido do nosso actual estado de saber acerca da propria natureza do germen da febre amarella, segredo que continúa até este momento trancado com sete chaves e sigillos, apezar dos heroicos e immensos esforços recentes de uma brilhante phalange de valentes investigadores. Comtudo não serí para sempre refractaria á vara magica da sciencia e ao espirito investigador da humanidade este segredo. Symptomas ha que permittem prever que o grande momento onde a mysteriosa fechadura saltará já não está muito longe; certos estalos perceptiveis nos ultimos tempos a ouvido do auscultador, sĩo um presagio disso.

Se assim devemos justiça á replica do nosso interlocutor, podemos por outro lado, continuando na discussão do imaginario calso acima formulaco, fazer valer o direito que por equidade nos assiste, de reclamar pezo e medida igual. Vimos que uma femea de Stegomyia fez-se expressão da longevidade extraordinaria e quasi infinita do individuo, para no momento dado submetter-se aos interesses da especie de mosquito. Ora, não seria supposição fóra do alcance da possibilidade admittindo que, quer no mesmo vapor ou navio de véla, quer em diversas viagens, fizessem simultaneamente sua travessia, fóra do porão, outras femeas de Stegomyia, encarregando-se estas especialmente da missão de inocular na tripulação e nos passageiros o germen amarillico e de perpetuar a especie da molestia. Semelhante divisão de trabalho, principio funclamental da hodierna economia social, bem assentaria a este modernista mosquito, qual o é a Stegomyia. Aliás essa divisão de funcções sobre diversos individuos da mesma estirpe é no caso entre Stegomyia e febre amarella tão imprescindivel, como no caso entre Anopheles e malaria e um dos pontos cardeaes para uma elucidação bem succedida d'estes importantes problemas é, ao meu vêr, o de nunca perder de vista que elles, qual busto de Jano, têm sempre um duplo rosto: frente, mosquito-homem; dorso, homem-mosquito (conforme minha brochura anterior sobre os Mlosquitos no Pará, pag. 27). Nem toda a femea de Stegomyia é vector de febre amarella; é preciso que ella seja previamente infeccionada. Ora, felizmente para nós nem todas são de facto infeccionadas, embora que a todas seja inherente a capacidade theorica de sel-o. Mas lí rem a mysteriosa interferencia da natureza, que manda esta femea de Stegomyia ser 
boa mãe, ao passo que instiga aquella outra a ser zelosa transmissora de um morbo mortifero ao genero humano!

Poderia haver quem fizesse a objecção de que a perpetuidade da especie para a Stegonyia só pareceria efficazmente garantida, n'um caso como o acima imaginaco, quando pelo menos um casal conseguisse realisar a traressia. Mas tal argumento não procede á vista das minhas experiencias ( $I$, caixa A, pag. 48 seg.), que mostram a quasi infinita vitalidade do sperma no receptaculum seminis da femea, isto e, a longa efficacia de fecundaçôes anteriores. E aliís viamos tambem, que os machos da Siegomyia não ficam muito atraz das femeas em longevidacle, tendo sido observado um, que após 72 d’as de captiveiro ainda fugiu (Exp. 19, pag. 50).

Já se vê, que o caso da Arca de Noé póde achar a sua repetição, em relação á tigrina Stegomyia fasciata, em nossos dias, frequentes vezes por qualquer vapor ou navio de véla!

Entre as conclusões praticas a tirar do ponto de vista sanitario, creio dever apontar principalmente para as seguintes:

1) As nossas experiencias demonstram nitidamente que, realizada a riagem, convem dissolver o convivio dos passageiros quanto antes, - que não se deve prolongar este convivio, são portanto contrarias ao antiquario uso das quarentenas;

2 ) estas mesmas experiencias demonstram que as quarentenas seriam com vantagem subst:tuidas por frequentes e radicaes desinfecções (1) com reactiros efficizes ( dioxido de enxofre, etc.), interessando os porões;

3 ) vapores, naregando, com especialidade e regularmente entre portos sitos na zona tropical e pretendendo obedecer nos seus arranjos internos ás indicações hy. gienicas modernas contra os perigos acarretados pelos mosquitos transmissores cie molestias, deveriam ter como dormitorios para a tripulação e os passageiros, accommodações providas com tela protectora, systema "Grassi ».

BELEM DO PARA:

Dezembro, 1903 -Janeiro, 1904.

(1) Conf. Nuttall and Shipley Journal of IIygiene:, Vol. II., 1. ( Jan. 1902), pas. 83. 


\section{III}

\section{Pormenores biologicos principalmente relativos ao cyclo de desenvolvimento das principaes especies indigenas.}

\footnotetext{
Nur das kennt man. was man in Werden verfolute.

I. Meierle, Urgeschichte der Schweiz . 1901, lag. 9.

. From what little we know concerning the - eygys of Culicidae, it appears that each ge* nus has not only a differently formed egge. " but often a different mamer of depositing athem. *

Theobald, Monograph of Culicidae. 1901. Vol. I, prag. 19.

We have no information as to the eggs - of the other genera of Culicidae and as a matter of fact, our knowlecige on this point * is very scanty and further observations are "much reruired.".

Giles, Handbook of Gnats or Josquitoes, 190:2, pag. 127 .

*In by far the rreater number of recor- ded spiecies the larrae have never been - recognised and still less described. The e accurate deseription of the larvae of the e accurate deseription of the larvae of the great inpiortance; lout it is unfortunately - that one can, as yet, be hardly said to be (commenced, s)

Giles, ibidem. prag. 40.
}

\section{1. - Culex fatigans. Wiedemann. (1828)}

(Mosquito adulto (imago) veja Estampa colorida I, fig. 4 (femea), fig. 5 (macho) oros e larvas e seus pormenores: Estampa A e B, figuras 1-28).

\section{Ovo.}

Um esboço geral já foi dado no meu primeiro trabalho, pag. 19 e seg. (Biologia dos Mosquitos). As numerosas figuras originaes que agora damos, constando de photographias e desenhos feitos ao microscopio, dão uma tão perfeita idéa dos caracteres especiaes, que dispensam extensos commentarios a respeito. Não deixa de ser curioso que, apezar dos muitos autores que têm tratado do assumpto desde 
Réaumur até hoje, [se admittimos, como devemos fazer fóra de duvida que as observatções feitas com relação ao Culex pipiens, L. europeu e ao C. pungens norte-americano são extensivas e applicareis na sua essencia á nossa especie], e entre os quaes recentemente Miall, (1) Howard, (2) Giles, (3) e Theobald (4) darem as resenhas relativamente as mais circumstanciadas, uma tentativa monographica completa tanto pelo lado descriptivo como pelo lado iconographico constitue ainda um desideratum, não se encontrando discussão comprehensiva de alguns detalhes, ao nosso vêr, bem interessantes e dignos de attenção.

A orientação radial dos oros na jangada (conforme nota abaixo do Cap. I, pag. 19) vê-se distinctamente n'um dos grupos da figura 2.

Se collocamos a jangada fresca sobre a lamina microscopica, sem cobril-a, deparamos com o exquisito aspecto da fig. 6 , de certo capaz de nos sorprehender pela cxactidão geometrica do seu desenho.

Os circulos escuros correspondem cada um a um ovo, visto do alto; as partes triangulares claras arrumadas em torno, em fórma de estrellas, são os intersticios entre cada ovo e os seus dous visinhos contiguos. Pallidamente indicado vê-se isto tambem já na figura 3 , embora em escala muito mais diminuta. Cheios de ar estes intersticios, que são umas gallerias perpendiculares do comprimento dos ovos (para ter uma idéa exacta basta consultar o aspecto apresentado por um feixe bem apertado de alguns lapis redondos, quando examinado por um dos extremos, contra a luz), facilmente se comprehende que devem contribuir efficazmente para impedir e evitar o perigo da submersão da jangada.

No mesmo sentido vem outrosim auxiliar o mechanismo da bolhasinha transparente, collocada na ponta fina do ovo fresco de Culex fatigans, - ao qual alludi no Cap. I, pag. 19. E' perfeitamente visivel nas figuras photographicas 7 e 8 da Estampa A da presente Memoria, onde é rista obliquamente de cimá e de lado. Julguei a principio que a bolhasinha fosse de ar, accompanhando bona fide a opinião de diversos autores que de passagem a ella se referiram. Ultimamente porém a reflexão e a observação me demonstraram que o conteúdo deve antes ser uma substancia gelatinosa mucilaginosa, attentas as suas qualidades opticas e sua maneira de comportar-se em dirersos liquidos ambientes usuaes na technica microscopica. A bolhasinha desprende-se com bastante facilidade do seu logar, sob a mais leve pressão, affasta-se fluctuando e costuma depressa desapparecer por completo, tendo ís rezes augmentado ainda de calibre n'um estado de turgidez. Na mesma occasiaxo cheguei a convencer-me que aliás toda a jangada fresca de Culex fatigans jaz com a sua base n'uma nuvem gelatinosa, semelhante á gallerta que serve de primeiro envolucro aos ovos de tantos outros insectos e até de animaes vertebrados, - haja vista a cos cordões dos oros dos sapos, etc. Comtudo não rejo motivo para attribuir á bolhasinha outra funcção que a hydrostatica. Tanto o material

(1) The Natural Ilistory of Aquatic Insects, London 1003.

(2) Mosquitoes: Ilow they live, etc., New Iork 1902.

(3) Ilandbook of the Gnats or Mlosquitoes, London 19(1)..

(4) Monograph of Culicilae 1901-1902 (3 vol.) e Vol. IV (supplemento) 1903. London. 
para a bolhasinha como o que constitue a camada gelatinosa maior que envolve a superficie inferior da jangada serão sem duvida fornecidos por uma certa e determinada porção da parte terminal do apparelho ovopositor. Tendo notado que a dita camada desapparece já antes do desmancho total da jangada, que se inicia pouco tempo depois de sahidas todas as larvas das suas capsulas ovulares, não seria para estranhar se as novas larvas se servissem d'esta materia como primeiro alimento. tro na base.

Dimensões do ovo de Culex fatigans: $0,71^{\mathrm{mm}}$ em comprimento; $0,16^{\mathrm{mm}}$ de diame-

A fórma especial do ovo, comparavel como adiante já disse, á feição da semente do pinheiro do sul do Brazil, é muito claramente demonstrada pelas nossas figuras 4 e 5. Na primeira, fig. 4, os dous ovos, embaixo á esquerda, quasi symetricos (pelos menos quanto a um) são apanhados no sentido dorso-ventral, ao passo que os outros todos são mais ou menos lateralmente vistos, correspondendo a linhá convexá ao lado dorsal, e a suavemente concava ao lado ventral. Deixam vêr por transparencia embryões larvaes em phase bastante adiantada de desenvolvimento, já sendo distinctamente visivel a segmentação do abdomen e a mancha ocular. Formação curiosa é o appendice em fórma cle taça sobreposto ao polo rombo, mediante um tenuissimo e curto pedunculo, perceptirel em dirersos oros da figura 4. E' uma pellicula transparente, que facilmente se desprende. Fallam d'ella e figuram-n'a Miall á pag. 112 e Howard á pag. 67, sem todavia precisarem pormenor algum, nem se pronunciarem sobre a sua significaç̃o morphologica. Creio dever reconhecer n'este appendice um mero residuo do periodo intra-ovarial, resto da "camara germinativa" primitiva, inteiramente sem utilidade physiologica, uma rez o ovo posto. Este problematico appendice tem, ao exame microscopico com forte augmento, uma estructura assaz curiosa, como mostra a nossa figura 11, que dá uma idéa do aspecto frontal interior. Um systema de pontos finos, arrumados radialmente ao redor de uma depressão central, produz um desenho de um disco semelhante ao sol.

Bastante para extranhar é o facto de ter passado até está hora, por assim dizer, completamente descurado e neglicenciado por parte dos já numerosos escriptores hodiernos sobre mosquitos, o estudo minucioso da cstructura exterior da pellicula ovular. Entretanto ella offerece amplo material de estudo, como terei occasiao de provar no decurso d'esta Memoria, e apresenta distinctivos especificos que serão reconhecidos de incontestavel valor systematico e pratico.

Relativamente ao ovo do Culex fatigans, são as nossas figuras 9 e 10 altamente instructivas. A figura 9 mostra o polo delgado de um ovo, visto ao microscopio com augmento mais consideravel: em toda a circumferencia percebe-se um serrilhado fino, que, ao exame de augmento ainda maior, se mostra ser o producto de uns mui pequenos elementos chitinosos transparentes, arrumados qual palissada e rombos na ponta (fig. 10). Levantando-se o tubo do microscopio, o aspecto frontal do ovo é igual ao que se vê na fig. 9, metade direita, originando-se uma granulação finissima, composta de tuberculos de contornos redondos. Estes elementos marginaes são perpendicularmente orientados com o seu eixo em relação á superficie do ovo.

Para dar sahida á larva o ovo de Culex fatigans abre-se, nat parte romba, por uma dehiscencia transversal e circular, ficando todavia presa a tampinha á casca orular rasia, como perfeitamente se póde distinguir nás quatro jangadas do lado direito na nossa fig. 3. Uma vez sahidas todas as larvas, a jangada desorganisa-se rapidamente, 


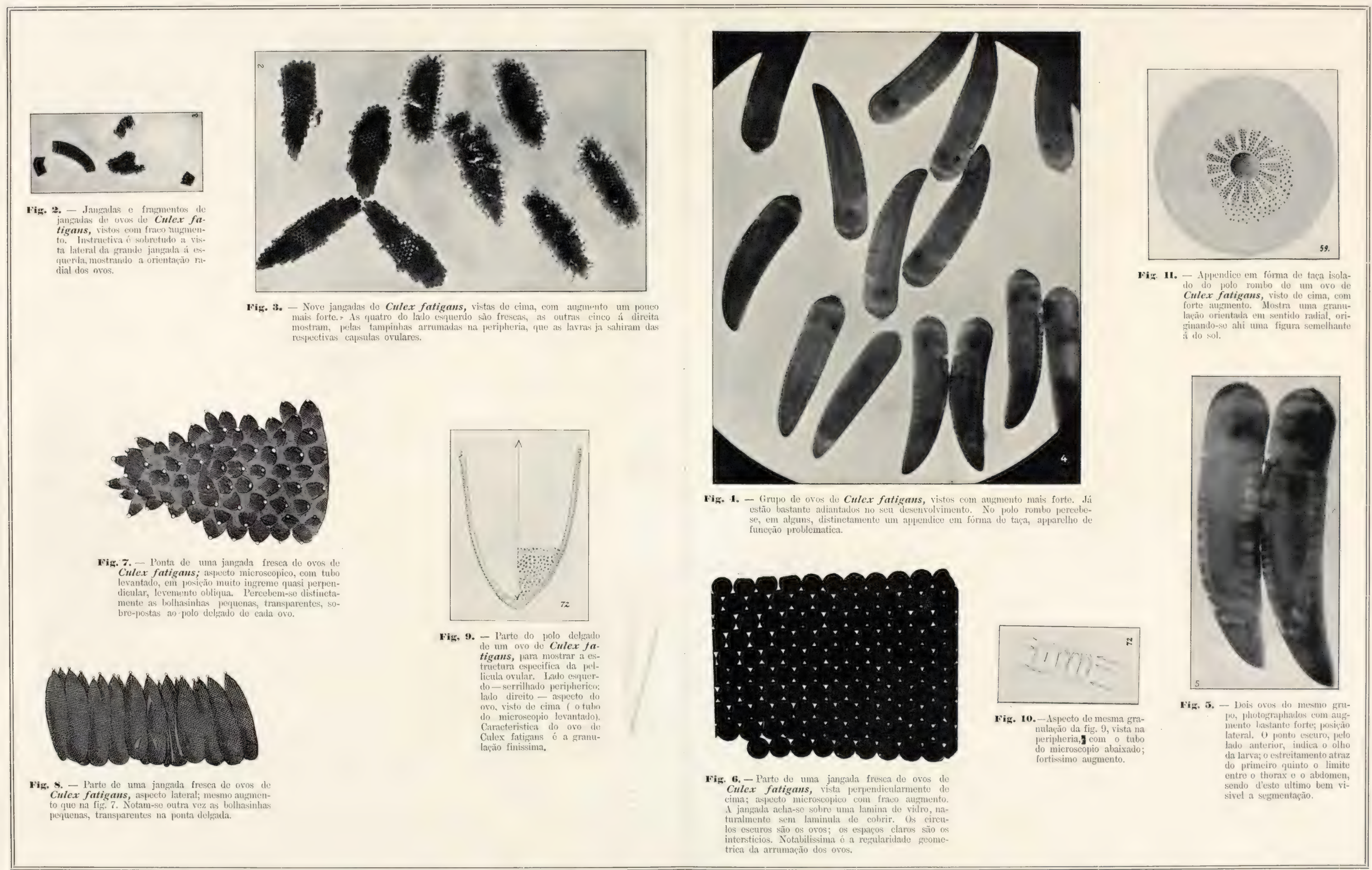

Culex fatigans (I.) 


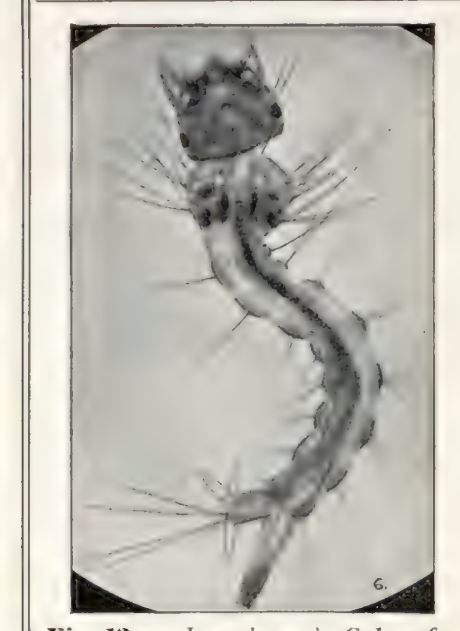

Fig. 1:. - Joven larva de Culex fa
tigmin, do um dia de idade, vista

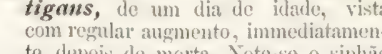
te deprois do morta. Note-se o siphliay
respiratorio anal bastante comprito
as antemas comyuridas.

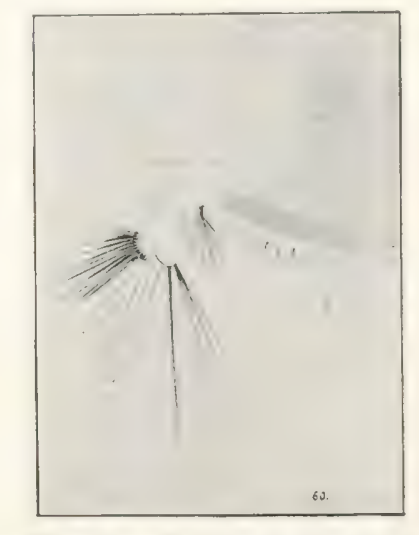

Fig. 211 . - Desenho da prarte aboral
da mesma larva da fig., 20, em es recimento de un respeitavel tus

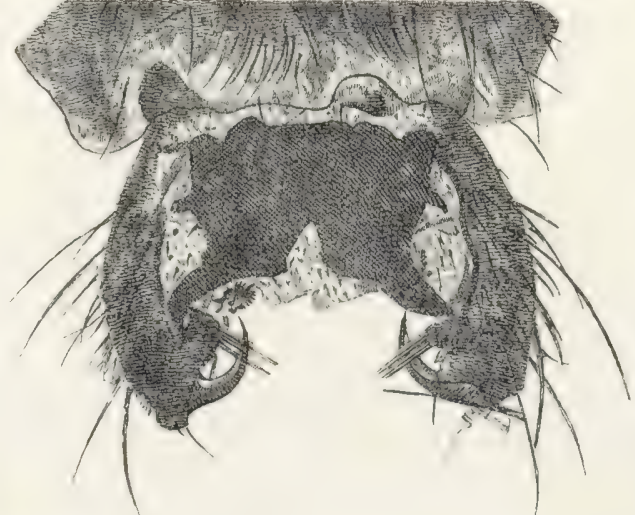

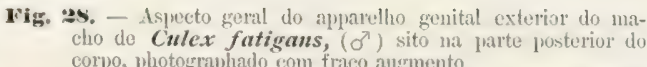
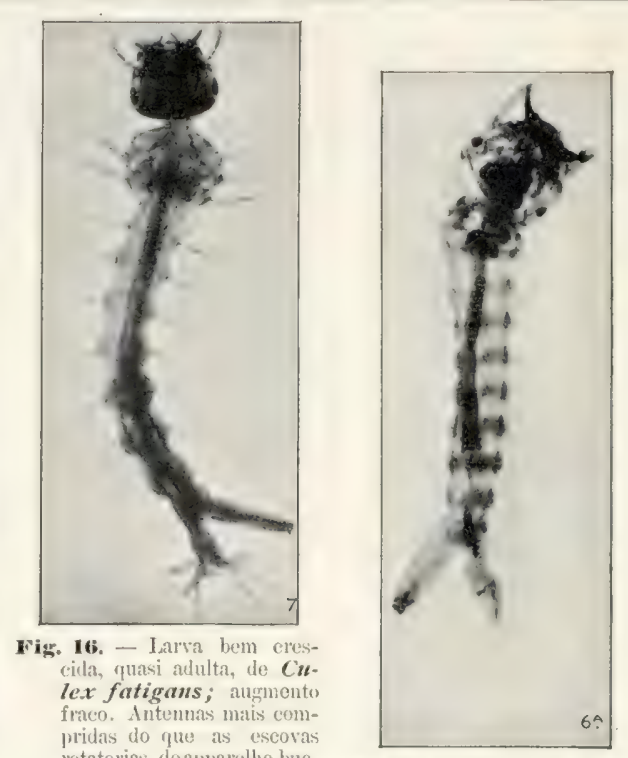

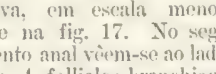

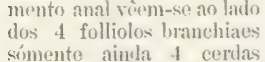
comente aimla $f$ cerdas
compridas o vistosas, mas
não 0 tufo ulterior.

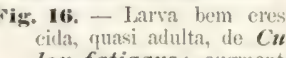

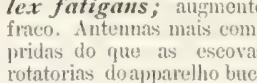

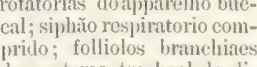
Vig. 18. - Larva da me do systeman trachenal do
mensives antes reduzidas.

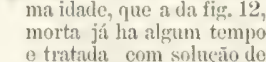
fuchsina para tingil-a,

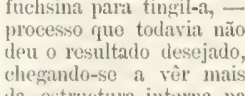

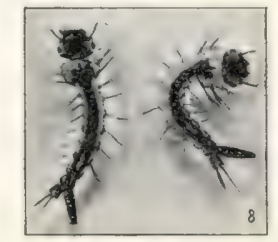

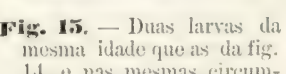

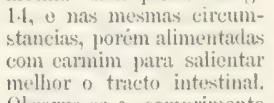
Observe-se o comprimento
velativimente traudt do si-

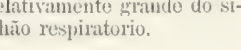

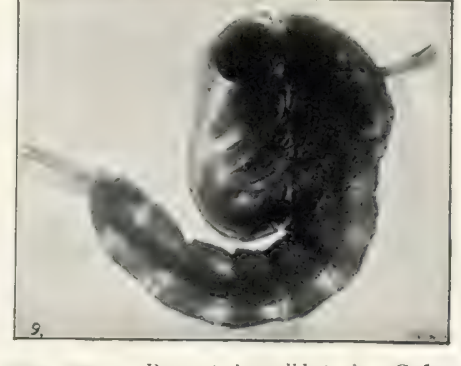

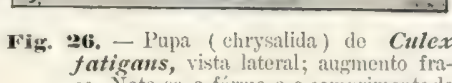
fatigaths,
co. Note-so a fúma 0 o comprimento do

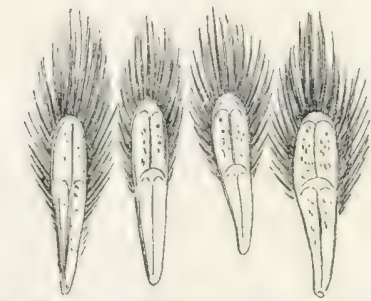

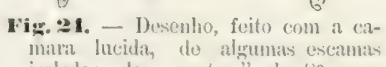

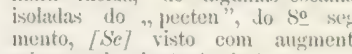
mieroseopico bastanto forte.

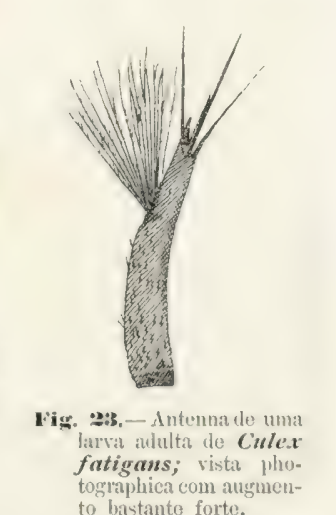

tographica comm augmen-
to bastanto forte.

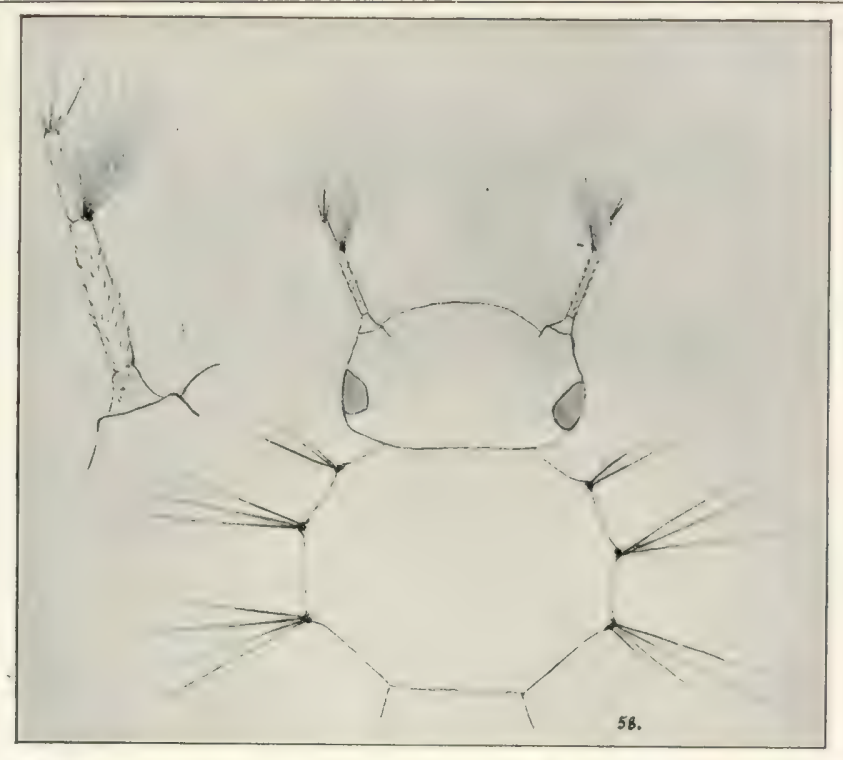

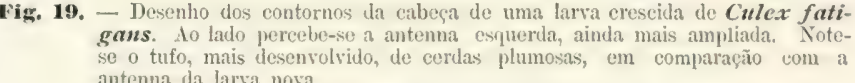

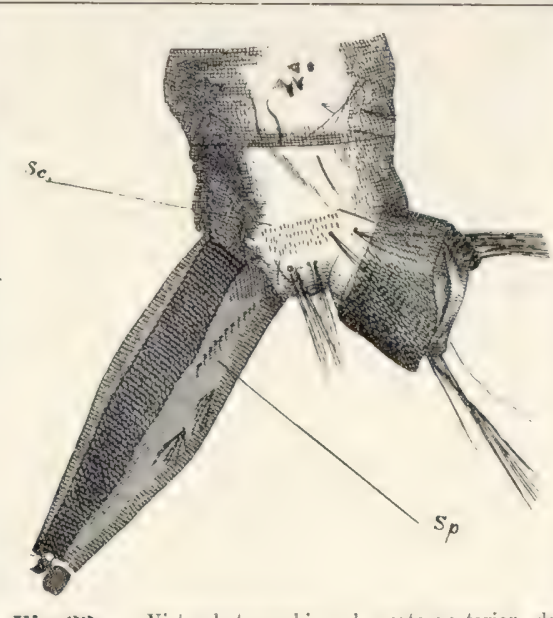

Fig. 2y. - Vista photographica da parte posterior de

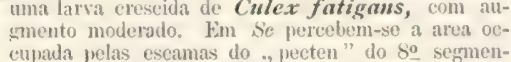
to, visiveis como riscos peqtienos o finos arruma-
dos em linlas trunsversaes; em Sip observa-se o dos espinhlos, longitudiualmente enfileirado: no siphão respiratorio.
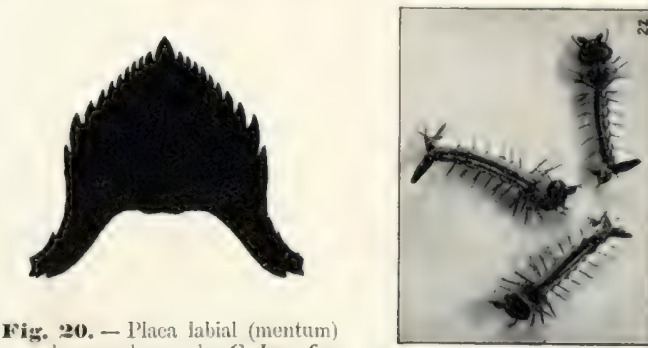

Niv Now

Fig. :30. - Placen labial (mentun

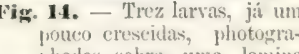

phiadas sobre una lamin
porta-objecto, n'tuma gotta
d'aguat pouco augmento.

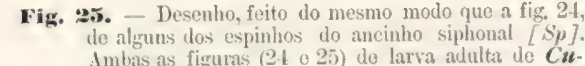
lex fatigans.
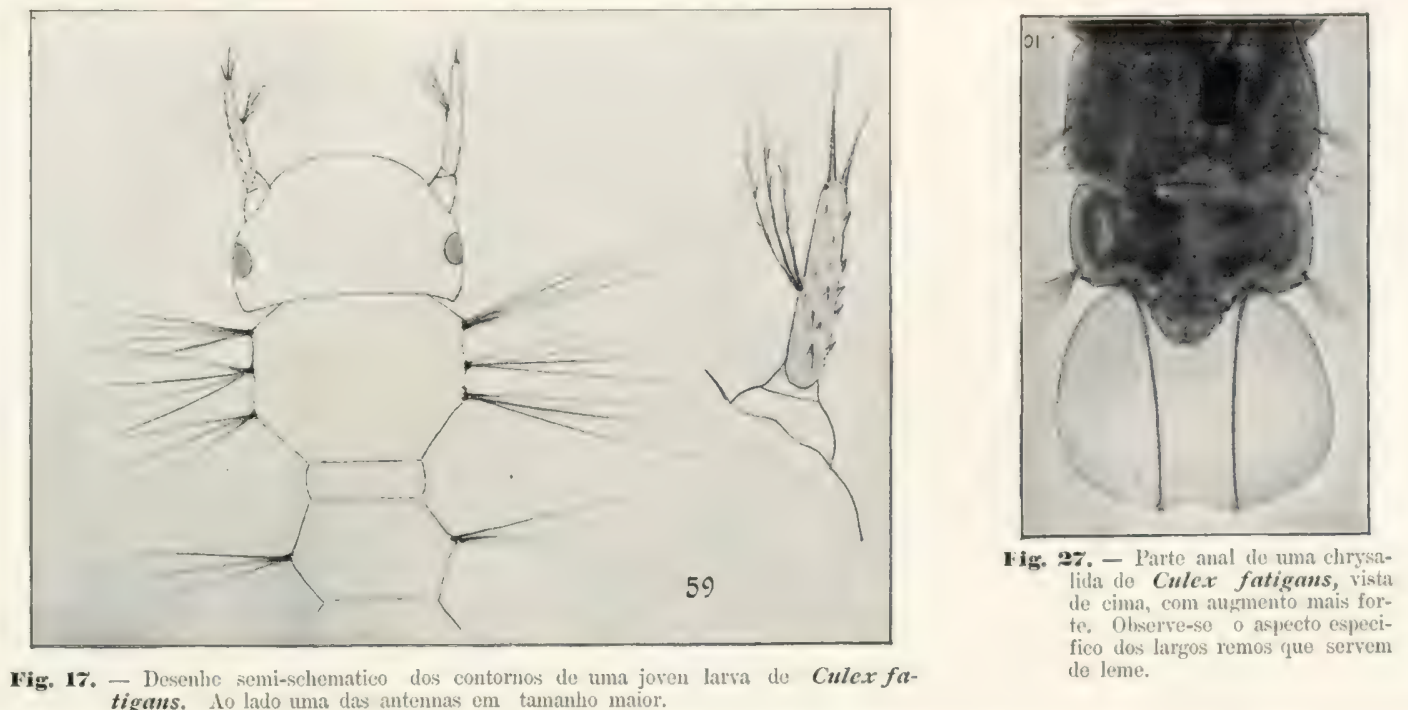

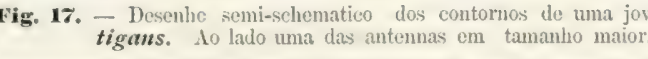
Lo leme 
fraccionando-se em parcellas pequenas, que até não tardarão a ser deroradas pelas proprias larvas novas, especialmente se no respectivo boccal não houver muita fartura de substancias alimentares.

Quero aqui intercalar uma observação significativa em relação aos logares predilectos para a postura das jangadas de ovos do Culex fatigans. Tendo ficado recentemente, por accaso, aberto um boccal de vidro alto, cylindrico, collocado na officina taxidermica d'este Museu, e contendo uns craneos de alguns mamiferos menores previamente limpos dos principaes musculos, para ahi serem submettidos á maceração, para faclitar a limpeza ulterior, no fim de 2 a 3 dias já se observou na superficie d'esta agua um numero espantoso de jangadas de Culex fatigans, pelo menos 100 a 200. Se houressemos permittido as larvas todas livremente se desenvolverem, ellas teriam correspon dido, moderadamente calculado, ao bello contíngente de 30000 ! Impressionado por esta observação casual, repetimol-a diversas vezes intencionalmente, e sempre com o mesmo resultado: taes depositos com agua, contendo objectos de origem animal para a maceração, são com visivel aridez procurados pelas femeas do Culex fatigans para a postura de seus oros. Evidentemente estas femeas escolhem, como guiadas por um instincto, semelhantes aguas putridas onde ha farta pastagem para as pequenas larvas, que se desenvolvem no nauseabundo meio ás mil maravilhas. São os microscopicos urubús das aguas sujas.

Opino que d'esta observação poderá tirar-se proveito pratico, sabendo que taes vidros constituem localidades que intensamente alliciam as femeas de Culex fatigans que querem pôr os seus ovos, lá onde ha muito d'este flagello, vale a pena expôr de quando em rez boccaes especialmente apparelhados para este fim, a modo de «arapuca », exterminando todas as manhans a rica colheita de jangadas de oros que ahi terá sido depositada durante a noite. Esta tactica offerece a vantagem de concentrar as localidades procuradas pelos mosquitos femeas para depositar a sua prole, em espaço pequeno e de facil e certeiro alcance, em vez de serem as jangadas espalhadas sobre uma porção de esconderijos cliversos, dos quaes muitos escaparão á vigilancia.

\section{Larva.}

Nro obstante os muitos autores que citam e fallam da larra de Culex fatigans crmo de uma cousa perfeitamente conhecida, não encontrèi na litteratura á minha disposição resenha alguma completa, que exgotasse o assumpto. E' curioso como logo principiam a minguar os clados, quando se procura qualquer descripção detalhada e se inquire dos distinctivos especificos proprios a uma qualquer phase de desenvolvimento. E' um terreno onde tudo fica ainda por fazer em relação aos mosquitos do Brazil, podendo ser apontado como modelo digno de imitar-se o modo com que se aprofundia modernamente a historia natural dos Mlosquitos indigenas por parte dos entomologistas norte-americanos. O que nós apresentamos aqui não é senão um primeiro pásso n'este sentido e n'esta direcção.

O habitus geral da nuva larva de Culex fatigans é demonstrado pelas nossas figs. 12 e 13. Instructivo sobretudo éo confronto com a nova larva de Stegomyia fasciata, na mesma phase, visivel na fig. 47. Confira-se tambem com a figura 49. Além de bom numero de differenças perceptiveis que se descobrem ná feição geral, fórma da cabeça, arranjo e comprimento das cerdas marginaes, etc., etc., duas principalmente ferem a 
nossa attenção: o siphão respiratorio anal relativamente compriclo e as antennas complicadas e plumosas insertas na cabeça.

Quanto ao siphão, pelas figuras photographicas $12,13,14$ e 15 , é claramente demonstrada a sua consideravel dimensão longitudinal.

A larva crescida, adulta (figs. 16 e 19 ) por sua vez differe da nova (figs. $12 \mathrm{c}$ 17). Não é tanto á proporcional largura da parte thoraxica que quero alludir, pois esta costuma ser sempre relativamente grande nas larvas maduras, em qualquer clas especies de mosquitos. No que concerne á parte anterior, por uma comparaçĩo clos nossos desenhos (figs. 17 e 19) rê-se logo que as antennas das larvas novas (fig. 17) sx̃o ainda menos plumosas que as das adultas (figs. 19 e 23). Na parte opposta nota-se o mesmo phenomeno de mudança do estado mais simples para o mais complicado (figs. 18 e 21). O siphão respiratorio na larva nova (fig. 18) possue apenas umas poucas cerdas compridas e o segmento anal tem, como guarnição unica, os quatro folliolos branchiaes e um ramalhete de quatro cerdas rijas e compridas, sahindo de commum de um coxim situado pelo lado interior. Na larva adulta, porém (figs. 21 e 22) percebe-se no siphão pelo menos dous ramalhetes pequenos finos de pellos, dous algo maiores entre o siphão e o segmento anal, e n'este segmento, além dos quatro folliolos, uma escora ristosa de pellos grandes pelo lado exterior, e um feixe de fortes cerdas bem compridas pelo lado interior.

N'esta occasião devemos nos approximar do estudo de umas formações typicas, de incontestayel importancia systematica e sitas n'esta parte terminal da larva adulta de Culex fatigans. Pela fig. 22 vê-se que existe pelo lado interior do siphão, $\mathrm{cm}$ arranjo longitudinal, uma fileira de diminutos espinhos, que eu designarei com o nome de ancinho siphonal. (Sp.). Dei da sua fórma caracteristica um desenho, feito ao microscopio com forte augmento e com o auxilio da camara lucida. (Fig. 25). Estes espinhos ou esporões sĩo revestidos de um lado de uns 4 a 5 dentes agudos, orientados obliquamente no sentido postero-mediano. Ná figura 22 depara-se outrosim, entre siphão c annel anal, um campo estriado de finissimos riscos transversalmente arrumados (Sc.). São umas formações chitinosas, aqui modeladas um pouco sobre o feitio da base de uma penna, que chamaremos escamas do pente (pecten) anal. Tambem d'estas escamas damos um desenho fiel, executado com forte augmento microscopico. (Fig. 24). Contei d'ellas, no exemplar photographado, 38, quando dos espinhos siphonaes havia uma dupla fileira, cada uma de 11.

Pelo lado inferior da cabeça da larva ha, entre as peças componentes do apparelho buccal, uma outra systematicamente importante: a placa labial (mentum), cuja configuração especial no Culex fatigans nos dá a vista photographica 20, organisada com augmento bastante grande. E' uma formação semelhante a uma pá, provida na margem anterior, de cada lado, de 10 dentes assaz agudos, achando-se ainda um maior no meio, na ponta. Podemos exprimir esta relação pela formula $10+1+10$. Esta peça presta certamente optimo serviço á larva na sua faina de alimentar-se, porque é intuitivo que agindo no sentido postero-anterior qual enxó ou formão permitte por exemplo á larva, quando encostada á uma parede, pedra, folha, etc., que seja, raspar o limo, as algas e semelhantes substancias ahi adherentes. Debalde procurei uma figura da placa labial do Culex fatigans authentico em autores anteriores: não encontrei nenhuma. Em compensação ha semelhança bastante grande com a illustração dada acerca do mentum 
do C. pipiens, fig. 72, pag. 328 da obra de Ephraim Porter Felt "Nosquitos or Culicidae of New-York State» (1904) e a figura 4, Estampa 43, lettra 1, relativa ao mesmo Culex pipiens na obra clo mesmo autor "Aquatic insects in New-York State" (1903) e bem assim com a figura 6, ainda relativa á mesma especie, Estampa III da brochura de John B. Smith "The Common Mosquitoes of New Jersey" (1904).

A mesma semelhança existe entre as figuras que dizem respeito aos pormenores dos espinhos (Sp.) do ancinho siphonal [compare-se o meu esboço (fig. 25) com a figura 8 de Smith $]$ e ás escamas do pecten anal $[$ compare minha figura 24 com a figura 9 le Smith]. Especies norte-americanas, que com relação a diversos d'estes pormenores mencionados proram ser proximas aparentadas do nosso Culex fatigans são o Culex restuans Theob. (E. P. Felt. Mosq. N. Y. St. figs. 70 e 71 ; Aq. Ins. N. Y. St., plate H), 0 Culex sylvestris Theob. (Smith C. M. N. Jersey plate IX figs. 6, 8 e 9), e o Culex sálinarius Coq. (ibid. 8 figs. 4,5 e 9 ).

Comtudo creio que é cedo ainda para formar juizo definitịo e final desde já acerca das relações do nosso Culex fatigans com o C. pipiens da Europa e o Culex pungens norte-americano. Aqui é o logar de externar a minha duvidit, se o desenho II da figura 16, pag. 28 do Vol. I da Monographia dos Culicideos do Prof. Fred. W. Theobald (1901) se refere realmente a uma larva do Culex fatigans por causa do siphão anal extraordinariamente estirado ou senĩo se trata talvez antes de uma larva do parentesco do Culex territans Wlk. norte-americano ou do Culex confirmatus Arrib. neotropical. Igualmente nutro duridas acerca das figuras que, de novas larvas de C. pungens, deu o Prof. Howard na pag. 69 da sua obra "Mosquitoes" (1902). Aquellas larvas têm antennas tão compridas como o nosso C. fatigans jamais os possue. A reflexão me collocaria nesta alternativa: ou o C. pungens norte-americano é especic realmente diversa do nosso C. fatigans ou então ha exagero na dita figura relativamente ao comprimento das antennas.

Os quatro folliolos branchiats ao redor da abertura anal (figs. 12, 16, 18 e 21) são de um oval lanceolado, como sempre muito transparentes, e igualam de perto $\mathrm{cm}$ comprimento o proprio segmento anal, ao passo que é contido 2 a 2 1/2 rezes no comprimento do siphão respiratorio conforme a idade da larva; este é atravessado longitudinalmente por um largo tubo tracheano, occupando perto da metade do lumen, é finamente estriado (1) no senticlo transversal, como aliís é regra para todas as partes do systema tracheano. Um tronco tracheano percorre o folliolo, pelo meio, em todo o seu comprimento distribuindo aqui e acolá ramos por ambos os lados, que parecem terminar na risinhança de bellas cellulas, ovoides, com nucleo distincto, disseminadas n'uma fita estreita marginando toda a circumferencia e mostranclo um protoplasma granuloso. Trata-se provarelmente de terminações nervosas. Tambem estes folliolos branchiaes são compativeis em servir de distinctiro especifico-systematico; infelizmente não nos foi possirel extender illimitadamente o material illustrativo, faltando assim aqui, contra o nosso gosto, mais amplas figuras relativas a estes delicados orgãos interessados tanto na respiração como na circulação na economia interna da larra.

(1) Nìo é estriado em toda a largura o siphão. como se poderia suppor guiando-se pela figura 9 pag. 71 do alias excellente livro do l'rof. Iloward. 
Durante a redacção das presentes linhas deparei ainda no recente rolume supplementar da Monographia dos Culicides do Sr. Fred. V. Theobald, publicado em 1903, pag. 225 - 227 descripção, accompanhada de algumas figuras, relativa á larva de um mosquito chamado Culex fatigans, subespecie Skusii Giles e baseada sobre exemplares enviados de Queensland (Australia) pelo Dr. Bancroft. Não posso deixar de extranhar a surpreza que me causam as differenças relatiramente grandes que eu noto n'estas larvas australianas em comparação com as minhas do Pará. Vejo folliolos branchiaes muito compridos e ponteagudos, um segmento anal longo, espinhos do ancinho siphonal com 6 e 7 raios lateraes e uma antenna recta, relativamente fina na base e pouco plumosa na metade distal. Tamanhas divergencias com aquillo que eu tenho de considerar como norma do typo larval do Culex fatigans paraense devem forçosamente suscitar duridas, se o tal C. Skusii, da Australia, não será antes especie distincta do que simples subespecie.

Em todo o caso ha aqui mais uma vez uma advertencia significativa, quanto urge finalmente um processo uniformisado, exacto e minucioso nas descripções das diversas phases de desenvolvimento das especies de Culicides observadas n'esta e n'aquella região. Se a systematica d'ora em diante não fôr sempre accompanhada pari passu por cuidadosos estudos biologicos, dentro em pouco ella tornar-se-á um intrincado liabyrintho de erros e confusoes, onde ninguem mais se entenda.

Errar podemos, na verdade, todos nós; mas se cada um se esforça do maximo cuidado e exactidão nas suas dissertações, este estado chaotico que ameaça alastrar n'este terreno, forçosamente terá que ceder a um discernimento claro e nitido.

\section{Pupa (Chrysalida).}

A apparencia geral da pupa de Culex fatigans nos é ensinada pelas figuras 26 e 27. A primeira nos mostra o animal em vista lateral. Principío por confessar que, se ha uma phase da rida do mosquito, dereras rebelde em patentear distinctivos especificos, é certamente a este estado de pupa que cabe a palma. Assemelham-se umas âs outras de tal modo, que é desesperadamente difficil conhecer com inteira segurança tal especie, sómente sobre uma unica chrysalida, sobretudo quando ella fôr ainda muito nova.

O unico traço que permitte reconhecer rapidamente a chrysalida de Culex fatigans é a tuba respiratoria, no lado dorsal do thorax, relativamente comprida. Não me é possivel entrar aqui em discussão circumstanciada, acompanhada de farto material illustrativo, d'este orgĩo. Figuras devéras satisfactorias d'elle ainda não vi, parecendo-me que em geral do estudo minucioso d'este apparelho não tem havido mais contribuição e progresso dignos de nota além do que foi levado por F. Neinert em 1886, que com a sua habitual mestria o investigou na especie Culex annulatus. ("Eucephale Mygge larver" Tab. I fig. $11-14$ ).

No Culex fatigans é uma especie de cartucho, dirigido para traz, com uma profunda chanfradura obliqua pelo lado exterior, e deixando perceber uma estructura escamosa na parte terminal.

A parte aboral do corpo da chrysalida de Culex fatigans (Fig. 27) termina em duas laminas caudaes transparentes, arredondadas, em fórma de possantes remos. Ha 
meio de conhecer, se uma chrysalida é masculina ou feminina, porque o processo mediano que contém as gonapophyses tem um feitio mais alongado quando a imago a sahir tiver de ser masculina, mais curto quando feminina (1). Assim a nossa larva aqui escolhida pertence ao sexo feminino.-

Quanto ao apparelho genital exterior do insecto alado (imago) constitue um desideratum ainda n'esta hora uma nomenclatura scientifica assentada, relativa ás diversas peças que o compũem em individuos d'este ou d'aquelle sexo.

Falta assim praticamente a possibilidade de discutil-as verbalmente de um ponto de vista comparativo e ainda não surgiu para as Culicides um Lyonnel ou um LacazeDuthiers! Estamos d'est'arte limitados á confrontação de figuras, podendo o leitor fazerse uma idéa adequada do aspecto do apparetho sexual externo masculino de Culex fatigans pela figura 28, que é feita de uma rista microphotographica. E' assaz parecido com as vistas respectivas, que se encontram no livro de E. P. Felt (Mosq. N. Yórk State), Est. 38 e 39, relativas ás especies C. pipiens (fig. 4), C. restuans (fig. 3) e C. salinarius (fig. 1).

\section{2. - Culex confirmatus Arribalzaga (1891)}

(Mosquito adulto, alado, reja Estampa colorida IV, fig. 17 (femea ₹); ovos, larva e pupa e seus pormenores Estampa C, fig. 29-33).

Este mosquito, assaz facil de conhecer pelo espaço luzidamente branco, como prateado na parte anterior do thorax, é assaz frequente em campos, capinzaes e hortas, por mais seccos que elles sejam, uma vez que não faltem poços, tinas artiticiaes e depressões naturaes para a irrigação. Noto-o aqui no Pará, de preferencia no verão, como o encontrei em abundancia impressionadora no Rio de Janciro, no estabelecimento horticola de um amigo meu, sito em Villa Isabel. Por lĩ mostrou-se devéras impertinente, não se podendo fazer um passo siquer, sem se ser assediado por uma turba de 10 ou 12 d'este Culicidio caracteristico, (2) E' diurno e assaz photophilo, sendo a gente principalmente por elle perseguido nas horas as mais calidas e ao sol ardente. E' dolorosa e irritante a mordedura, produzindo pelo menos em mim, um calombo relativamente grande. Encontro na obra do Prof. Theobald, Vol. II, pag. 44 a observação: "O Dr. Lutz diz, que esta especie se encontra nas margens innundadas de rios e em brejos, e pica de dia. (3)

Conhece-se, na actual phase de saber scientifico, existir ella nas seguintes localidades: Jamaica - Trindade - Guyana Ingleza (Weldad, Pomeroon) e Guyana Hollan-

(1) Foram Nuttall e Shipley que chamaram pela primeira vez a attençào sobre esta circumstancia no seu sempre memoravel trabalho sobre o Anopheles macuiipennis, pas. 272, fig. A B-C D.

(2) O Sr. L. Irribalzaga (Dipterologia argentina 1891, pag. 43) tinha proposto para esta e para uma outra especie, albifasciatus, o novo nome generico (c)lerofatus, cuja significação de "molestissimo s nào iria mal a este Culicideo, pelos naturalistas argentinos apanhado na Provincia de Buenos Ayres e no Gran Chaco.

(3) Desperta assim as minhas duvidas a asserção que loģo segue clo Dr. Grabham na Ilha de Jamaica; This species appears to be active only during the night, \& Iqui nẩo laverá confusio ? - Assim parecem-me naturalmente de valor problematico as indicaçóes lá contidas acerca das larvas e do desenvolvimento. 
deza (New Amsterdam) - Pará (Durham; Goeldi) - Rio de Janeiro (Moreira; Goeldi) - São Paulo (Lutz) - Republica Argentina (Rio Salado; Formosa).

Acerca do desenvolvimento d'esta especie nada me consta de certo até hoje pela litteratura; no recente volume supplementar (1904) o Sr. Theobald não teve a accrescentar progresso algum relativo ao C. confirmatus na pag. 171.

\section{Ovo.}

Extraio do meu diario de observações as seguintes notas:

De. 3. femeas de Culex confirmatus, trazidas das matas de Murucutú no dia 16 de outubro de 1903, morreu uma logo, tomando as duas outras sangue de cobaya no mesmo dia, no dia 17 uma, no dia 19 ambas, no dia 21 ainda uma. Após um intervallo de 4 dias, a 20 de outubro, appareceram os primeiros oros, em numero de 10 , sobrevirendo a respectiva femea ainda 2 dias. Seis dias mais tarde, em 22 de outubro, appareceram mais 25 oros, morrendo então a femea horas depois.

Dimensões do oro de Culex confirmatus: $0,605^{\mathrm{mm}}$ de comprimento; $0,15^{\mathrm{nmm}}$ de largura na parte mais larga, (valor medio de 6 ovos).

A fórma do oro (figs. $29,30,31$ ) é um bello oval-lanceolado; póde-se comparar com o feitio de um charuto ou de um torpedo.

O mais largo diametro corta approximadamente pelo terço do comprimento total do oro. O polo delgado tem a ponta arredondada; o polo rombo mostra uma peça de rolhamento alargada, munida de duas azelhas transparentes (figs. $30-31$ ).

Quanto a estructura externa da pellicula ovular, tenho de declarar que a circumferencia se mostra guarnecida com um serrilhado de clementos marginaes delicados, transparentes e arredondados. São relativamente achatados e extensos no sentido da largura, mostrando alguma semelhança com os do ovo de Mansonia. Cabe dizer que, n'este pormenor, guardam uma posição intermediaria entre os ovos de Stegomyia fasciata e Taeniorhynchus por um lado, e os de Mansonia por outro. Infelizmente ficou esquecido fazermos em tempo opportuno um desenho illustrativo d'este detalhe.

\section{Larva.}

Dos oros postos em 22 de outubro de 1903 descobriu-se pela primeira vez no dia 30 de outubro apenas 2 larvas novas, que se deixou de estudar então, para não incommodal-as. Acontece, porem, que desappareceram pouco tempo depois, de maneira que fiquei privado de traçar aqui a competente descripção, relativa ás primeiras phases da larva de Culex confirmatus.

Um acaso todaria me fez chegar ís mãos a larva adulta, que me reio com uma colheita de diversas outras trazidas do mato da visinhança. E' de um habitus bastante caracteristico (fig. 32). Distingue-se pela cabeça grande e larga, antennas compridas, cerdas thoracicas longuissimas e sobretudo por um siphão respiratorio anal muito longo, estreito e fino, tubular, igualando em comprimento bem os 5 ultimos segmentos abclominaes.

Neste particular assemelha-se bastante ás figuras que dão, da larva do Culex territans Walk, norte-americano, Smith loc. cit. Est. X, fig. 1 e Felt loc. cit. pag. 30s, fig. 45, e da do Melanoconion atratum da Trindade e da Jamaica, dada por Theobald, Pl. 16, fig. 1 do Vol. IV (supplementar). 


$$
\begin{aligned}
& \pm 19 \\
& -c
\end{aligned}
$$




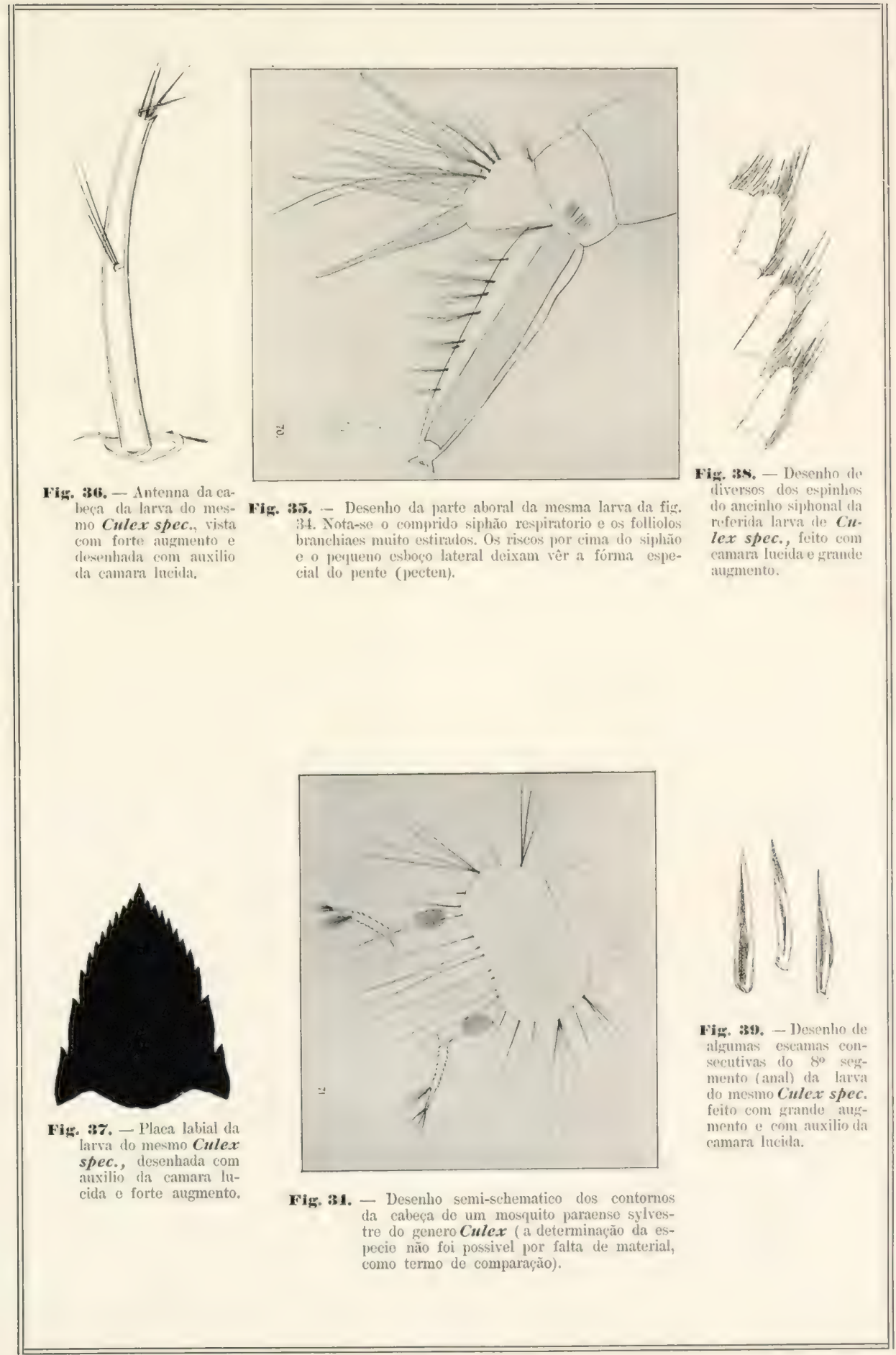

Culex spec. 

Sinto que n'aquella occasião deixasse de estudar e desenhar, com a desejavel minuciosidade, os detalhes relativos aos espinhos do ancinho siphonal e as escamas do pecten da larva do nosso Culex confirmatus. Fica isto para outra vez.

\title{
Pupa.
}

O aspecto da chrysalida do Culex confirmatus é visivel pela nossa fig. 33 , que dá a vista photographica de uma pelle rasia, que já deixou sahir a imago. Apezar de um tanto avariada e cercada de detrictos, etc., permitte todavia apreciar perfeitamente o comprimento descommunal das trombetas thoracicas, finas e tubulares. Cousa semelhante conheço pela litteratura sómente na pupa de Uranotacnia sapphirina conf. Felt, Aq. Insects N. Y. St. plate 46, fig. 11 e na do Culex mimeticus das Indias, Theobald Vol. IV (suppl.) pag. 157, fig. 85.

\section{3. - Culex serratus Theobald (1901)}

(Mosquito adulto, alado; veja nossa Estampa colorida III, fig. $1+$ (femea).

Este mosquito, reconhecivel já á primeira vista como proximo parente do Culex confirmatus Arribalz. (Est. IV, fig. 17), é caracterisado principalmente por uma larga estria longitudinal mediana, de côr griseo-argentea, por cima do thorax.

Foi colleccionado nas Guyanas Hollandeza e Ingleza; na Trindade; no baixo Amazonas (Austen, Durham) e Parí (Durham, Goeldi); no Rio de Janeiro (Moreira). Diurno e em todos os seus costumes semelhante a C. confirmatus.

Apezar de frequentemente trazido vivo de localidades paraenses proximas do Museu - por exemplo dos capinzaes ao redor do forno do lixo, - (entraram 3 femeas no dia 2 de dezembro de 1903; 2 \& no dia 17 de dezembro e 3 o no dia 19 do mesmo mez) e de quasi todas acceitarem, depois de installadas nas gaiolas, até por diversas vezes, sangue humano e de cobaya, morreram todas, sem excepção algumi, sem pôrem ovos nem deixarem progenitura. Das entradas no dia 2 de dezembro morreu a ultima no dia 7 , isto é, com 5 dias de captiveiro; das posteriores duraram uma 6 , outra 8 dias, numero este maximo de duraç̃̃o de vida observado.

Ficamos assim privado de nos manifestar sobre os pormenores biologicos do Culex serratus, tendo tambem faltado de sahirem imagines d'esta especie, das colheitas de larvas, ao accaso apanhadas no mato.

\section{4. - Culex spec. indet.}

\author{
(Est. D, figs. $3+-39$ ).
}

Das matas do Murutucú, na visinhança d'esta cidade, vieram-nos em outubro de 1903 diversas larvas de um Culicideo, de posição systematica ainda não averiguada. A 
estas se referem as figuras $3+-39$, mostrando a primeira (34) a cabeça e o lado anterior, a segunda (35) o lado posterior do corpo com o siphão respiratorio e partes visinhas.

Caracterisam a larva : uma placa labial (mentum), fig. 37, alta, em fórma de pá, com $10+1+10$ dentes na margem anterior, bastante parecida com o labium da larva do Culex fatigans (fig. 20), porém com a differença de ser inserido o ultimo dente consideravelmente mais contra a base; antennas regularmente compridas da fórma demonstrada pelo nosso esboço (fig. 36); cerdas thoracicas muito desenvolvidas e longas (fig. 34); um siphão anal assaz longo (fig. 35), guarnecido, pelo lado interior, de uma serie de tufos de pellos plumosos e finalmente por folliolos branchiaes singularmente estreitos, longos e subuliformes, como não os encontrei ainda em especie alguma alem dessa. Os espinhos do ancinho siphonal (fig. 38) são largos, da fórma de pá de cavar, com muitas ccrdas finas, delicadas, na beira, que não são faceis de se perceber todas de uma vez, tendo algo do geito que possuem as respectivas fórmas na Uranotaenia Sapphirina, conforme a fig. 81, pag. 352 da obra de Felt, New-York St. Culicidae.

Conto d'elles $12 \mathrm{~cm}$ cada uma das duas fileiras longitudinaes. As escamas coo pecten anal (fig. 39) apresentam-se como espetos simples, relativamente fortes, comparaveis aos figurados para o C. abserratus norte-americano, fig. 75, pag. 331 da citacha obra de Felt.

Uma pupa que possuo da mesma occasião, distingue-se pelo abdomen proporcionalmente largo, reforçado e ao mesmo tempo curto; remos caudaes arredondados; tubas dorsaes semelhantes ás do C. fatigans, talvez um pouco mais curtas.

Accrescentei estas notas, apezar do seu caracter fragmentario, principalmente em vista do feitio exquisito dos folliolos branchiaes da larva, do qual sómente me consta alguma cousa de parecido em figuras que na litteratura encontro de larva do genero Psorophora (conf. Howard loc. cit. pag. 149, fig. 41 ).

\section{5. - Stegomyia fasciata Fabricius (180う)}

(Mosquito adulto, alado (imago) veja nossa Estampa colorida I, fig. 1 (femea, vista de cima); fig. 2 (a mesma, em posição de repouso, vista de lado); fig. 3 (macho, de cima); fig. 3 a (casal em copula, roando); - oro, larva, pupa e seus pormenores. Est. E e F, figs. $40-63$.

Se em 1901 o melhor especialista dos Culicideos do mundo viu-se obrigado a confessar: "With regard to their (Stegomyia) larval habits I can record very little at present * (1) ninguem me dirá que o assumpto de uma biologia completa da Stegomyia

(1) Theobald, Monograph of Culicidae Vol. 1, pag. 4 . 
fasciata (1) tenha sido esgotado. Nem nos trez annos decorridos depois d'esta declaração appareceu trabalho que possa se vangloriar de semelhante serviço. Quem terá a coragem de gabar-se de ter fornecido descripça cabal de todas as phases de desenvolvimento d'este insecto, desde o oro até a imago, capaz de corresponder aos requisitos que a historia natural põe em materia de cxacta distincção scientifica?

Talvez a unica tentativa a registrar n'este sentido é apresentada pela resenha, dada no seu capitulo "The yellow-ferer Mosquito" pelo prof. Howard, dos Estados Unidos da America do Norte, no seu livro "Mosquitoes" New-York 1902, pags. 121140. Mas nem este autor esforçado no esclarecimento da biologia dos mosquitos norteamericanos attribuir-se-ia o ter feito mais do que um mero trilho n'este terreno, podendo-se ler, por assim dizer entre as linhas, a esperança que a elucidação completa ha de provir ainda n'um futuro proximo por parte de um observador favoravelmente situado na zona propria da Stegomyia fasciata.

\section{Ovo.}

Algumas notas preliminares acerca do ovo de Stegomyia fasciata já se encontram no meu primeiro trabalho, publicado em 1902, capitulo Biologia, pags. 19-20. As nossas figuras $40-46$ ajıdarão a comprehensão.

Dimensũes: $0,53{ }^{\mathrm{mm}}$ no comprimento (valor médio de 4 ovos) e $0,15^{\mathrm{mm}}$ de largura (valor médio de 3 ovos).

A figura 40 mostra a vista photographica, com fraco augmento, de uma femea de Stegomyia agonisante e boiando no espelho d'agua, depois de realisada a postura dos ovos. A figura 42 dá uma vista semelhante, com augmento um tanto maior, e em phase algo mais adiantada, porque diversos ovos já deixaram sahir as suas larvas, como se vê pelas tampinhas soltas e viradas para o lado. A fórma do ovo de Stegomyia é demonstrada pela figura 41, que é uma micrographia feita com augmento já regular. No aspecto dorso-ventral são de um oval assaz estirado. Vistos de lado, como são ambos na nossa figura, ha um lado quasi plano - o ventral, e outro convexo - o dorsal. Ha pouca differença entre os dous polos. O delgado é arredondado, rombo; o opposto, termina achatado com a habitual peça de arrolhamento, na qual se percebem em ambos os lados pequenas azelhas transparentes.

Entramos a tratar da estructura extcrior da pellicula vzular, valendo-nos n'este

(1) A separação da Slegomyia fasciata do antigo genero Culex e a creaçio de novo genero por Theobald para esta especie e as fórmas aparentadas foi, ao ver de todos nós outros, que nos temos occupado com alguma intensidade de estudos sobre a familia dos Culicideos, um nasso e innovaço francamente applandida. Foi mesmo um feito que altamente depóe em favor do inexcedivel tino e perspicacia systematica d'este notabilissimo especialista - feito tanto mais admiravel, qquanto Theobald n'aquelle tempo nảo tinha ainda conhecimento de todo o acervo de differenças biologicas e pathologicas proprias a Stegromyia e que elle tinha de deixar-se guiar principalmente por certos distinctivos da imago. Collocamo-nos de bom grado ao lado de tào consumados culicidistas como Iloward (op. cit. figs. 133.134) e Giles.(op. cit. pag. 261, pag. 368), quando se referem a esta creacio em termos de franco elocrio, e não hesitamos em fazer nossas as palavras d'este ultimo autor, quando exclama: "This is one of the most natural of the new groups of Culicidae, the members of the genus presenting an appearance that once seen is readily recornised.

Reputamos assim descabida e superflua a critica exercida em relação a esta questão de systematica e de nomenclatura zoologica pela Commissío medica franceza no Rio de Janeiro em certo trecho do seu * Rapport *, 1903, na pag. 680. A introduç̧īo de novos generos é a consequencia natural e logica do progresso e do crescimento do saber humano em relaçào a este ou áquelle grupo de organismos, - symptoma e signal caracteristico do sentimento da necessidade de meios para externar pela palavra um estado de discermimento systematico mais refinado e mais aperfeiçoado. Onde iria a gente parar, se tivessemos de subordinar as além de 400 especies de mosquitos, hoje conhecidos, todos ainda ao genero Culex, na concep̧̧io de Linneu em 1758 ! 
estudo as figuras 43-46. Examinado o ovo fresco da Stegomyia fasciata, com algum augmento microscopico já se nota que a circumferencia é toda moldurada por umas perolas transparentes (figs. 43 e 45 ). Com o auxilio de ampliação maior a gente se conrence de que este perolamento marginal é devido a uns elementos chitinosos, ora mais, ora menos arredondados, - n'este ovo, de calibre mais ou menos igual (fig. Ht); n'aquelle outro, alternando maiores com menores (fig. 46). Levantando e baixando o tubo do microscopio obtem-se respectivamente os aspectos patenteados pelos nossos desenhos (figs. 43 e 45 ) ao lado esquerdo e direito da linha longitudinal, correspondente ao grande eixo do oro. Sendo as depressōes preto-escuras, as protuberancias porém claras e, quaes aljofares, luzentes, ganha o oro da Stegomyia fasciata um aspecto todo granuloso e elegante. A granulação é bastante mais grossa que no oro de Culex fatigans. Por outro lado tambem não ha camaras aereas tamanhas, como o faz crêr a figura 14 , pag. 22 da obra do prof. Theobald, lettra $d$ (reproduzida tambem na obra de Giles, pag. 123, fig. 6). Orientados perpendicularmente sobre a peripheria os elementos marginaes em quasi toda a circumferencia do oro, nota-sa todavia uma certa tendencia de alongarem-se e de eriçarem-se em sentido obliquo contra o polo rombo. D'esta particularidade os dous oros na fig. 41 deixam ainda vêr um vestigio, embora que a photographia se mostre por rezes singularmente rebelde na reproducção de pormenores tão delicados.

Não ha a menor coherencia entre os ovos de uma postura de Stegomyia fasciata. Cada um vae para o seu lado, á mercê do accaso e das pequenas correntezas no lençol d'agua.

A dehiscencia da casca orular para permittir a sahida da joven larva é transversal e total, separando-se normalmente a tampinha, de todo, do resto do oro. Opera-se a um quarto do comprimento total do oro, contado do polo rombo.

\section{Larva.}

(Vejam-se as observações geraes no nosso primeiro trabalho, pag. 21).

A joven larva de Stegomyia fasciata, ao sahir da casca ovular (fig. 47) é um bichinho rermiforme, muito pequeno, corpulento e gordo, transparente ao microscopio c esbranquiçado á illuminação unilateral de cima. Comparada com a larva da mesma idade do Culex fatigans (fig. 12) notamos logo toda uma serie de differenças bem accentuadas.

A cabeça da larva de Stegomyia é mais redonda, de tamanho moderado, ao passo que é de feitio rectangular, larga e proporcionalmente grande na de Culex fatigans. O thorax por sua rez, guardando de perto a medida de largura da cabeça, é relativamente estreito na larva de Stegomyia, emquanto que tende a alargar-se, até igualar com a cabeça, na de Culex fatigans. As cerdas thoracicas amplas, rijas e compridas no Culex, são mais finas e delgadas na Stegomyia. Não ha duvida porém que a mais sensivel differença reside no siphão, que é largo, curto, reforçado, a modo de projectil de grossa artilheria moderna. Na cabeça são dignas de nota as antennas cylindricas, relativamente curtas e destituidas de pellos vistosos.

Se a olho nú talvez não é de todo facil distinguir com segurança as larvas de ambas estas especies em tão tenra idade, á medida que ellas crescem vai diminuindo a 


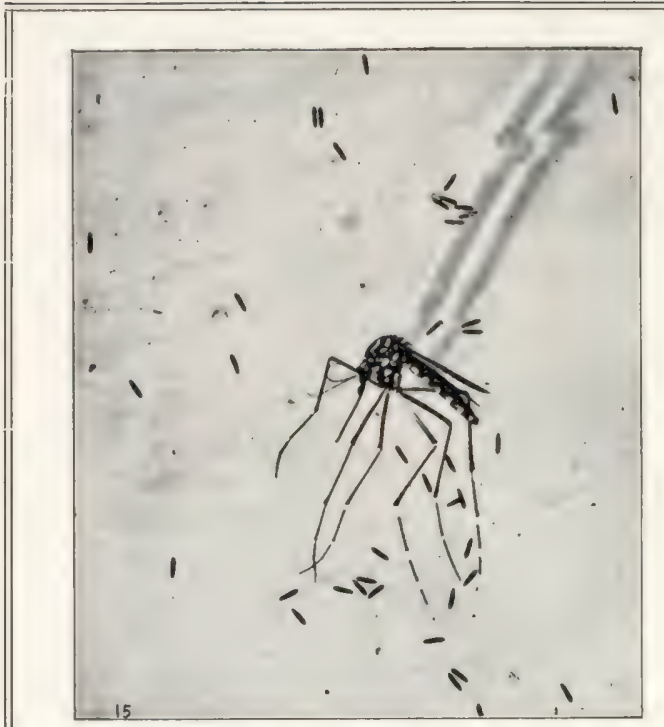

Fig. 40. - Femea de Stegomyia frosciata, aronisante, fluctuando at tona d'aguat depois de realisada a postura
dos oros. Fraco augmento.

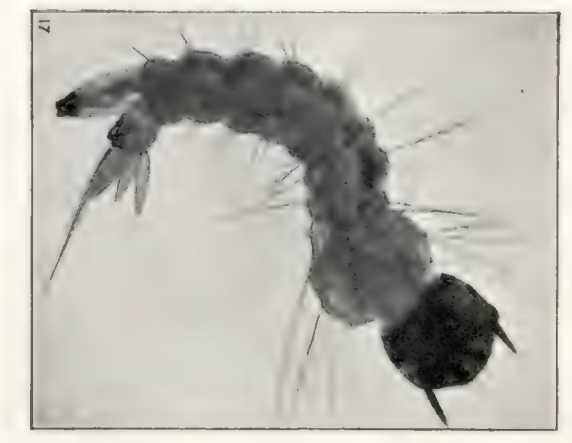

Fig. 17. - Vista photographica de uma joven larve augmento medio. Caracterisam a larva n'estas pliais

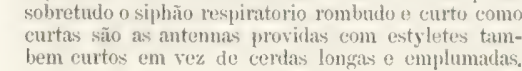

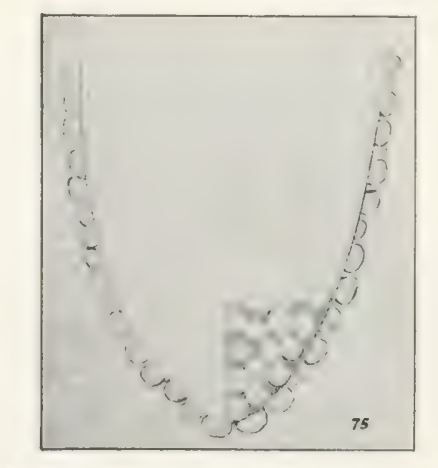

Yig. 45. - Desenho de outro ovo de Stc-
gomyia fasciata, mas mesmas eir-

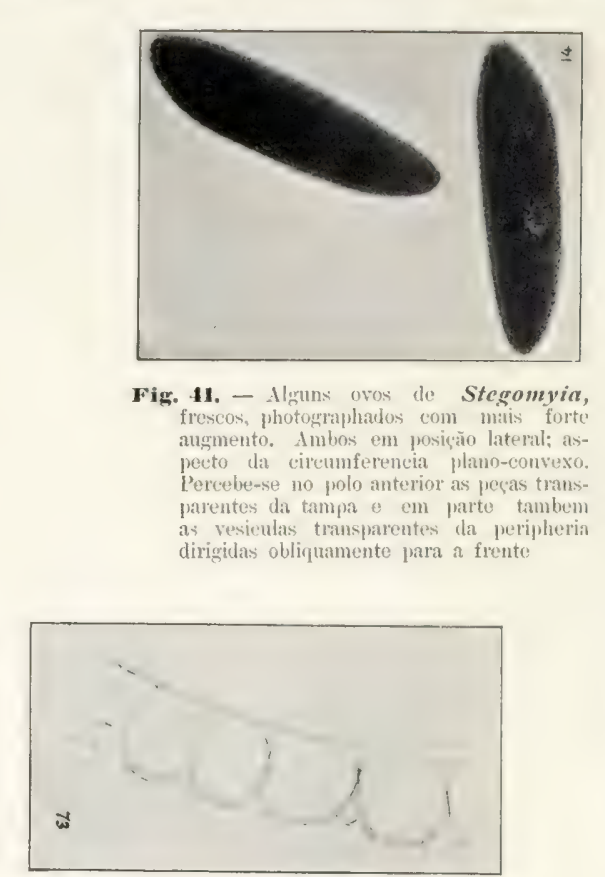

Fig. 14. - Alguns dos taes elementos periphe-
ricos a que allude a fig. 43 , vistos com ang-

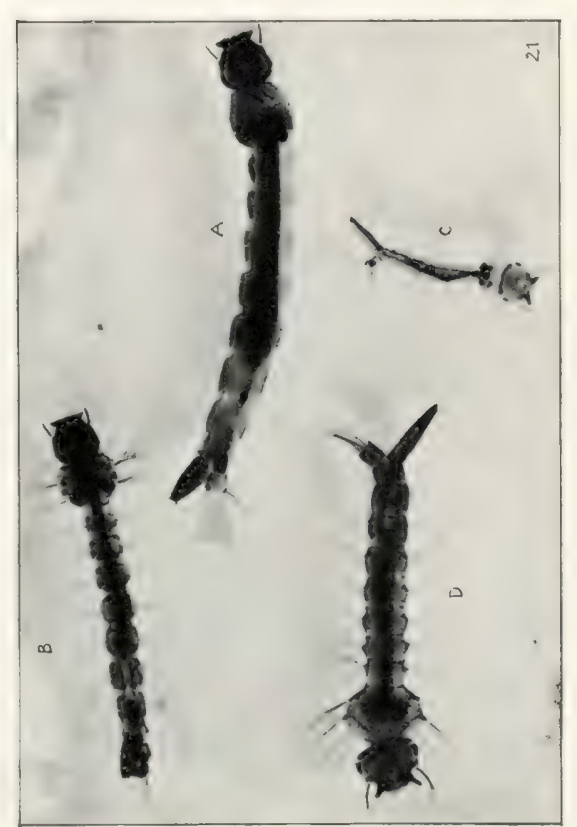

Vig. 49. - Algumas larvas de Stegomyia fasciato Ihadas sobro a mesma lamina porta-objecto para faciltar uma confrontacáa directa. Basta por exenplo, con-
siderar a tuba respiratoria anal em todos estes indivi-
doos, jara logo, à primeira vista, se reeonhecerem as

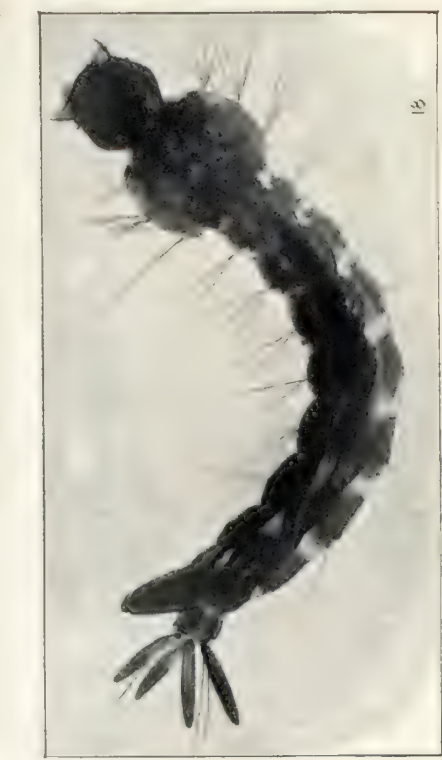

Fig. so. - Uma Iarva de Stegomyia, ba:
tante crescida, com fraco aummento.

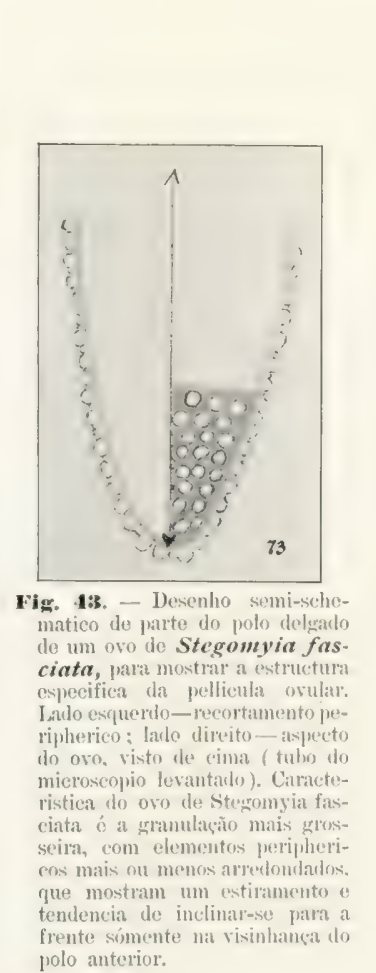

frente simente nit visisinhankata a
frolo anterior.

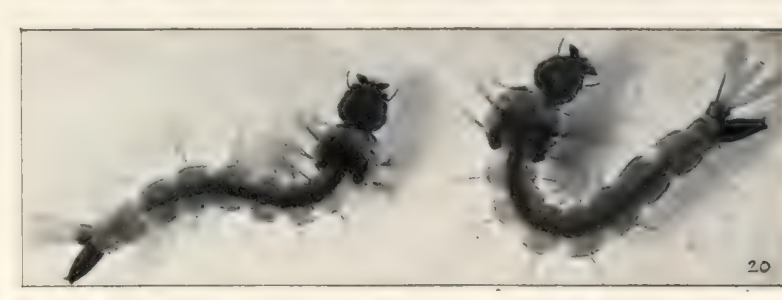

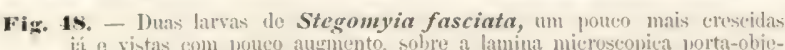

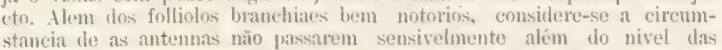
prossantes escevias ciliares lat bocea, apresentando um aspecto como itue rior da cabecat.
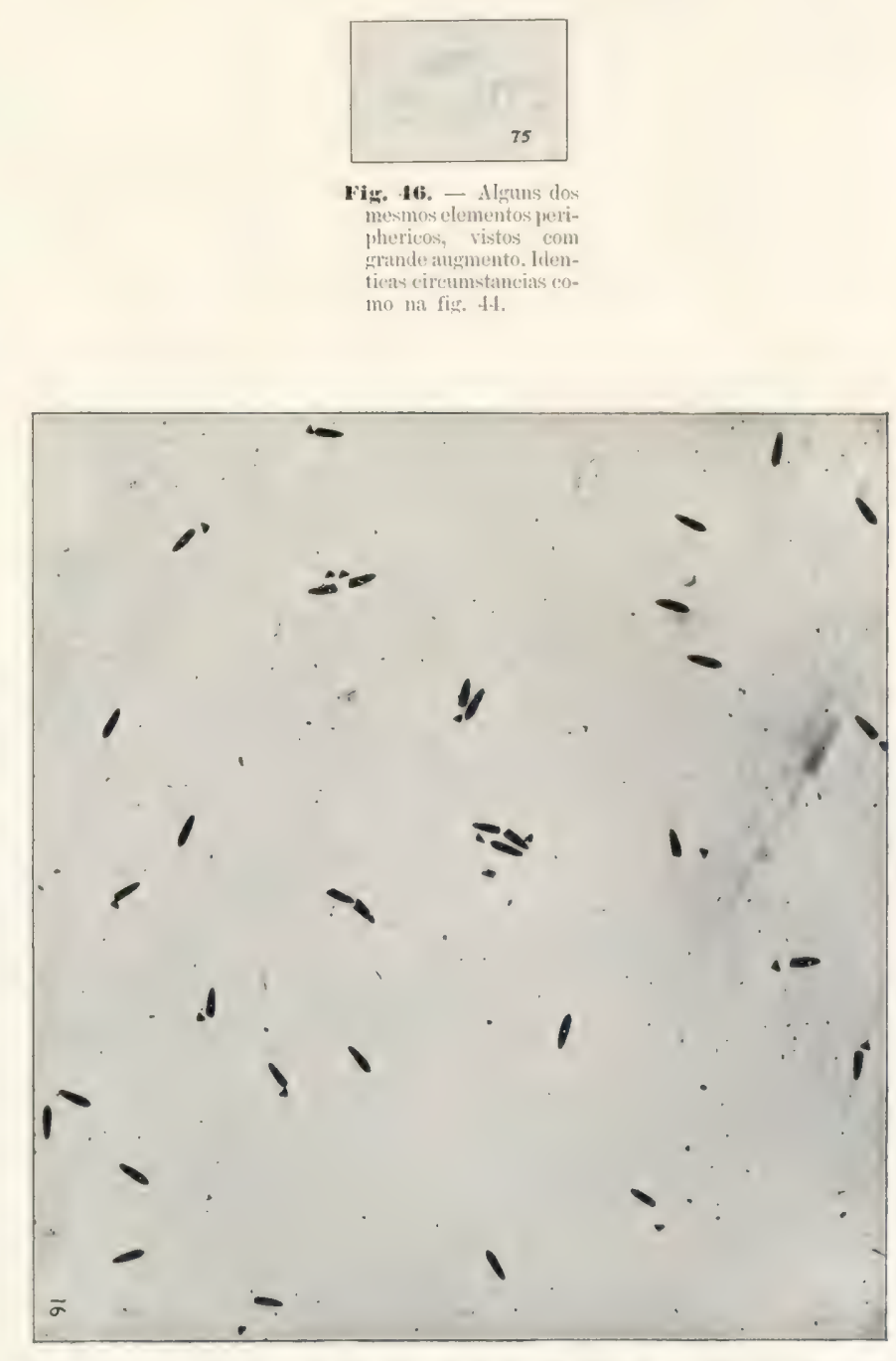

Fig. A2. - Aspocto de parto de uma prostura do oros do Stegomyia fasciata, com ang

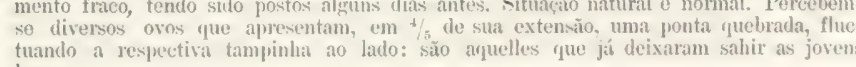




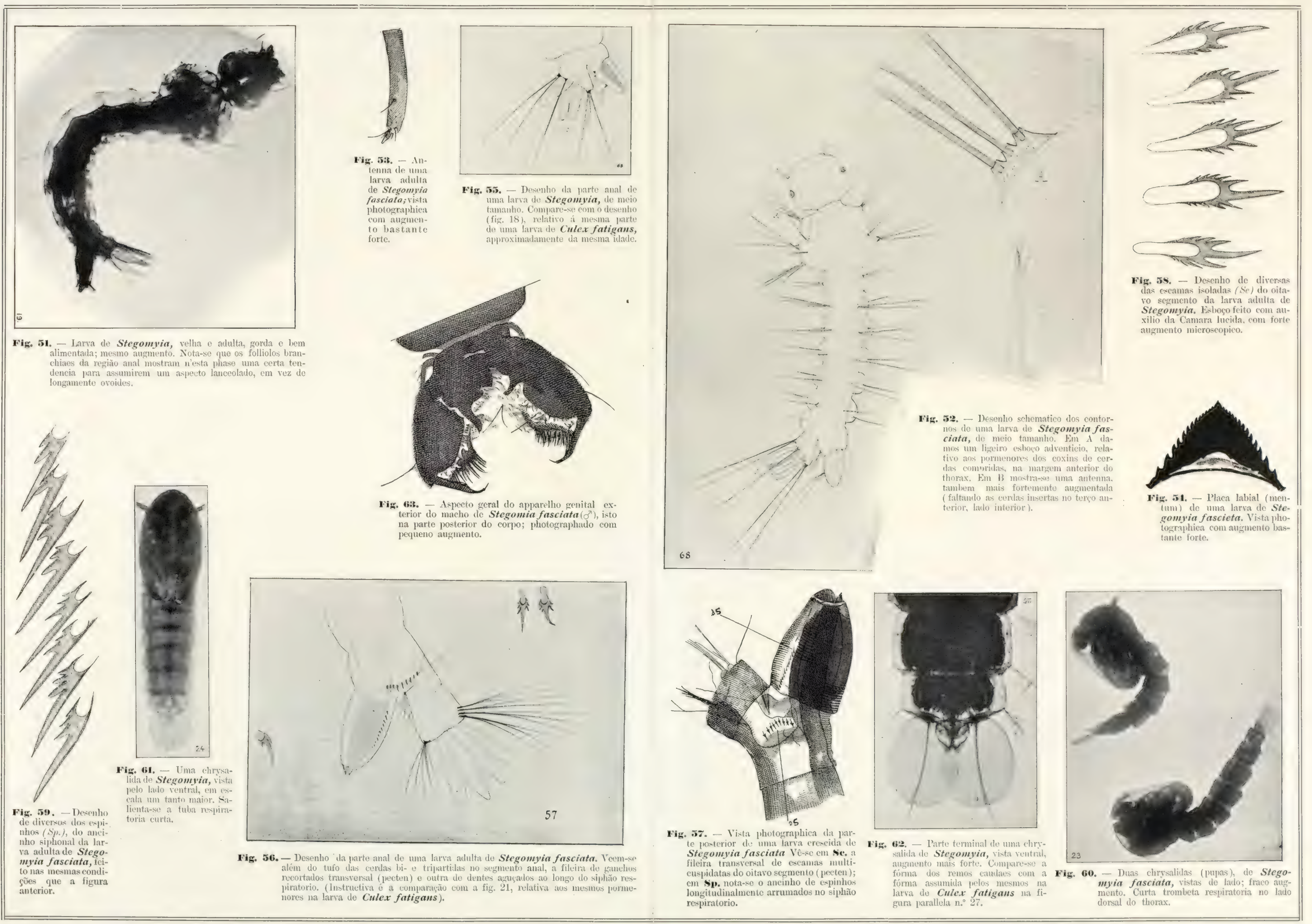

Stegomyia fasciata (II) 
difficuldade. A figura 49 mostra taes larvas umas ao lado das outras, quando na figura 48 vêem-se larvas de Stegomyia de meio tamanho.

As figuras 50 e 51 nos ensinam qual o aspecto da larva de todo adulta, estando a ultima já prestes a metamorphosear-se em chrysalida. Bastante caracteristica sempre afigurou-se-me a circumstancia de serem as possantes escoras buccaes como que aparadas com a tesoura, de maneira a formarem uma linha recta com a ponta das duas antennas. Os folliolos branchiaes, em numero de quatro, bem risiveis nas figuras 47,48 , - 50, 51, 52, 55 e 56 são de um oral bastante estirado, especialmente quando a larra jú fôr mais velha. Em larvas completamente adultas, como a da fig. 51, elles chegam ás vezes a assumir a fórma lanceolada. Todavia, ao contrario da de Culex fatigans, a ponta dos folliolos nat larva da Stegomyia é sempre romba, arredondada. Quanto á sua cstructura interna, não ha factores especiaes a mencionar.

Os outros pormenores larvaes são demonstrados pelas figuras $52-59$. Encontramos na figura 52 um schema dos contornos geraes da larva de Stegomyia. Em (A) se vê um esboço, em grande escala, de um grupo de cerdas sitas na margem anteriorexterior do thorax. Como se vê são ligeiramente pinnadas. Quanto ás antennas ( B, da mesma figura) constituem um dos mais salientes caracteristicos da larva de Stegomyia, o serem cylindricas, lisas ao redor, como truncadas repentinamente na ponta, onde, em rez de vistosas plumas e compridas cerdas, se notam apenas uns estyletes curtos; muito instructiva é a este respeito a nossa vista photographica (fig. 53).

Das partes buccaes, que foram bem analysadas e figuradas na pag. 136, fig. 35 da obra do Prof. Howard, merece a nossa attenção sobretudo a placa labial (mentum), da qual incluimos uma vista microphotographica original na fig. 54. E' representada por uma peça triangular, baixa e encurtada, com $13+1+13$ dentes ponteagudos na margem anterior, sobresaindo entre estes o mediano.

Quanto aos pormenores da região posterior da larva, recorremos ás nossas figuras 52, 55-59. A larva nova (fig. 55) possue além dos graciosos e elegantes folliolos branchiaes somente algumas poucas cerdas compridas. A adulta porém (figs. 56, 57) ostenta na margem exterior-posterior do segmento anal uma escova de respeitaveis pellos, além de outra na margem opposta, interna.

No siphão anal (figs. 56,57) o ancinho de espinhos é duplo e constituido por clementos, como o demonstra, em desenho feito em grande escala, o nosso esboço (fig. 59) (Sp. da fig. 57). São uns espetos tri e quadrifurcados. As escamas do pecten, do segmento anal, são arrumadas em uma unica fileira transversal, como resalta das nossas figuras 56 e 57. Têm exquisita fórma: um espeto medio e diversos outros dentes menores sitos, de cada lado, na sua base (fig. 58; Sc. da fig. 57). Possuem elles alguma semelhança com os elementos correspondentes na larra do Culex jamaicensis tanto quanto se póde julgar pela fig. 37, pag. 299 da obra de Felt op. cit.

Toda a superficie chitinosa da larva de Stegomyia fasciata é, estudada com cuidado e com forte augmento, finissimamente estriada no sentido transversal; diminutissimos espinhos chitinosos, curtos, são disseminados por toda a parte.

Quanto ás cerdas thoracicas, o terceiro e ultimo tufo de cada lado mostra á sua base um forte espinho curvo virado para a frente; no segundo tufo, o do meio, existe um espinho mais fraco, ao passo que no outro tufo, o primeiro da frente, como em todos 
trez da larva de Culex fatigans, as cerdas são implantadas n'uma simples protuberancia da fórma de um cône truncado.

Bastante caracteristico é o colorido da larva de Stegomyia fasciata, considerada no aquario ou na lamina com luz unilateral obliqua de cima. A cabeça é de um amarellaceo claro, côr de ambar; do thorax a parte anterior é branca, vidracea, ao passo que a porção mediana da metade posterior ña região das massas hepaticas (Giles) se mostra quasi preta. Bruno escuro, fuliginoso, ostenta-se todo o percurso do tracto intestinal, como comprida estria longitudinal atravez do abdomen inteiro; todo o resto do corpo, com excepção do siphão respiratorio, que é fuliginoso claro, apresenta-se n'um lindo tom esbranquiçado, hyalino. Bem diverso o colorido da larva do Culex fatigans: a cabeça é de um branco amarellaceo sujo, excepto a beira anterior buccal e a região dos olhos; do mesmo amarellaceo sujo que ás vezes toma um pallido tom rosado, é a metade do largo e possante thorax, e toda a zona lateral do abdomen. Bruno claro é o percurso do tracto intestinal e fuliginosos vemos o siphão respiratorio e a metade aboral das antennas.

\section{Pupa.}

Sobre o aspecto da pupa (chrysalida) de Stegomyia fasciata orientam as nossas figuras 60-62. O colorido é o seguinte: bruno-ennegrecida a parte dorsal; tom de tinta neutra as pernas ainda dobradas, visiveis por transparencia atravez do grande estojo thoracico; o chicote abdominal é amarellaceo, mais esbranquiçado pelo lado ventral dos segmentos, um tanto fuliginoso sobre as placas dorsaes, mormente nos primeiros da frente.

Um confronto com a pupa de Culex fatigans (fig. 26) ensina logo que a differença mais sensivel reside na tuba respiratoria dorsal muito curta da pupa de Stegomyia. E' um funil largo, quasi triangular, profundamente recortado ou dobrado em direcção obliqua, de modo a deixar patente larga abertura levando para o canal na base, quando vista pelo lado de fóra.

A figura 61 dá uma pupa de Stegomyia pela face ventral e na figura 62 vê-se a parte anal da mesma, em identica posição. Infelizmente quiz o accaso que para esta vista photographica servisse mais uma vez uma chrysalida do sexo feminino, quando teriamos desejado dar aqui uma do outro sexo. No sexo masculino o estojo central contendo as gonapophyses alcança perto da metade dos remos anaes. Estes remos são na Stegomyia talvez um bocadinho mais circulares e menores que no Culex fatigans.

Se quizessemos recapitular em poucas theses os distinctivos mais importantes que permittem reconhecer com segurança e presteza a larva e a pupa da Stegomyia fasciata, seriam as seguintes: 


\author{
1) cabeça redonda. \\ 2) antenna cylindrica, truncada, não plumosa. \\ 3) placa labial triangular, baixa, com $13+1+13$ dentes. \\ 4) thorax moderadamente largo; na base do terceiro tufo marginal \\ Larva: $\left\{\begin{array}{l}\text { um forte espinho curvo. } \\ 5 \text { ) siphão respiratorio curto, em fórma de projectil. }\end{array}\right.$ \\ 6) ancinho siphonal com espinhos em fórma de ganchos 3-cuspidados. \\ 7) pecten do segmento anal com escamas multi-espinosas. \\ 8) folliolos branchiaes arredondados na ponta. \\ 9) colorido geral branco-hyalino.
}

Pupa: 1) Tuba respiratoria thoracica curta, obliqua - e largamente aberta.

Quanto ao apparelho genital exterior, da Stegomyia masculina, informa a nossa fig. 53. Tornando a ser sensivel a falta de uma nomenclatura technica relativa ás diversas peças componentes d'esta armação e ás partes d'estas, á qual já alludi tratando do Culex fatigans, posso unicamente salientar que a tesoura, de cada lado, (comparavel a uma unha de caranguejo) possue no macho da Stegomyia sobre toda a aresta interior um pente continuo de fortes cerdas espinhentas reforçadas, notando-se ao mesmo tempo a ausencia do grupo de trez estyletes solidos postado na culminancia opposta ao grande gancho principal, como se percebe no Culex fatigans (fig. 28). Tambem pareceme faltar inteiramente na Stegomyia aquella subtilissima peça laminar, transparente, em fórma de remo indio, que no Culex fatigans se vê inserta n'uma proeminencia visinha do canto interior da tesoura. O colorido das principaes peças chitinosas apresenta-se fuliginoso na Stegomyia, amarello, côr de ambar no Culex fatigans. Ha um farto apparelhamento de valentes cabellos ligeiramente curvos pelo lado exterior das pernas da tesoura, tanto no caso da Stegomyia, como no do Culex.

\title{
Copula sexual.
}

Dizo o Rapport » da commissão medica franceza, textualmente, á pag. 687: «Accouplement. Deux fois seulement nous avons eu l'occasion d'observer l'accouplement: il a lieu presque toujours dans la nuit et à l'obscurité, d'où la rareté des observations de ce genre».

Peço confrontar por outro lado o que eu disse a este respeito no meu segundo trabalho, pag. 52 , onde empreguei os termos: «a (copula) vimos milhares de vezes e a vemos todos os dias». Circumstancia que, porém, ainda não tornei publica é que a copula de Stegomyia póde ser provocada ad libidinem, em qualquer hora do dia, mediante uma simplissima experiencia, que não vi negar uma unica rez. Se se tomar uma das nossas gaiolas de isolamento contando sómente machos de Stegomyia, ou apanhados em liberdade ou criados no captiveiro, e se se introduz uma femea da mesma especie. esta ño terá tempo de voar grande distancia sem ser logo apercebida e segurada por 
um macho. Isto se dará tantas vezes, quantas se repetir a experiencia, sobretudo quando se tiver o cuidado de escolher, por exemplo, como logar de observação, uma janella exposta a um brando sol de tarde. - Tive occasião de realisar esta experiencia perante não poucas pessoas da classe medica, entre ellas um distincto bacteriologista quando, vindo do Maranhão onde com denodo tinha dirigido o serviço sanitario durante o difficil periodo de peste, reio ao Pará, de passagem para o Rio de Janeiro. Facillima como é de ser provocada assim a qualquer hora do dia a copula sexual da Stegomyia no captiveiro, frequentissima é tambem de ser observada em liberdade, aqui no Parí, dia por dia, e não me consta que as cousas estivessem diversas lá no Rio de Janeiro. Aliás encontra-se, em corroboração das minhas observaçẽes no Parí, no Relatorio da commissão medica ingleza, relativamente ao Pará a significativa declaração: "The time of chief activity is in the middle of the day, from about twelve to two p. m., they then bite freely, and are seen to copulate on the wing in numbers. (pag. 5j).

\section{Se a Stegomyia fasciata pica normalmente de noite.}

No Relatorio da commissão franceza lê-se, á pag. 691 : "Divers auteurs ont considéré la Stegomya fasciata comme un moustique essentiellement diurne, que ne piquerait jamais ou presque jamais la nuit. C'est lì une erreur qu'il est indispensable de détruire».

Apezar do tom positivo d'esta asserção, continuamos com a mesma inabalavel conviç̧ão a assegurar o contrario, sustentando a nossa maneira de vêr já exposta em nosso segundo trabalho anterior publicado em janeiro de 1904 (pag. 82 da presente reimpressão). Declaro-me solidario, incondicionalmente, com as sensatas palavras emittidas a este respeito pela commissão medica ingleza no Pará (Report of Yellow fever expedition to Parí), pag. 55 e seg. no Capitulo "Habits of Adult ", iniciando logo no alto com a memoravel sentença: "This species in Pará is solely a day gnat ». Se erro ha, elle larra do lado da illustre commissão franceza, no Rio de Janeiro, tão completa e patentemente n'este como no caso da sua asserção acerca da pretensa raridade da copula sexual na mesma Stegomyia, e acerca da preferencia "da noite e da escuridão " para esta, como para as demais funcções as mais importantes da existencia de tal especie.

Duas series de factos em apoio do nosso modo de vêr.

I) No meu segundo trabalho pag. $6+$ (pag. 82 da presente reimpressão) já communiquei, que no meu gabinete de trabalho, no Museu do Pará, sou raras vezes picado de Stegomyia, quando tenho de trabalhar de noite com luz electrica. Esqueci porém de constatar ao mesmo tempo, que o mesmo gabinete está diariamente infestado de Stegomyias, de ambos os sexos, tornando me devéras difficil ás vezes o trabalho diurno. Como esse aposento dá para um angulo reentrante do edificio, cuja abertura corresponde quasi justamente ao quadrante $\mathrm{E}-\mathrm{S}$, varrido pelo vento dominante, as paredes que formam os lados desse angulo funccionam, de facto, como uma especie de funil, condensancio e canalisando para a minha janella os mosquitos diurnos e nocturnos 
arrastados pela correnteza aerea, de maneira que entram-me para o gabinete quantas Stegomyias produzirem as rocinhas circumvizinhas.

Ora, sendo d'esse modo continuamente assediado de dia por Stegomyias femeas, que me picam innumeras rezes, dando-me incessantemente provas irrefutaveis da sua constante presença, porque não me pica, de noite, n'este mesmo quarto, Stegomyia alguma, ou sómente uma ou outra por excepça rara, sendo at enorme maioria dos mosquitos picantes, que roando entram pela janella n'estas horas, composta de especies sylrestres como Taeniorhynchus e Panoplites? Entretanto ellas alli estão, n'aquellas mesmas horas, n'este mesmo quarto. Estão sentacias pelos cantos; repousam; não picam porque não querem e porque não precisam!

II) Apezar de constante attenção minha e de meus collegas nas nossas residencias particulares em rerificar casos absolutamente seguros de Stegomyias femeas, apanhadas em flagrante no acto de chupar sangue ou com os indicios de tel-o feito, durante a noite escura, ainda jámais conheceu-se um unico onde n'um mosquiteiro regularmente fechado se mostrasse uma tal Stegomyia, que provadamente se tiresse introduzido na escuridão da noite. Sempre são exemplares femeas de Culex fatigans que encontramos nos mosquiteiros como resultado da pesca da noite anterior. E todas as vezes que parecia ter-se apresentado finalmente um caso authentico, o exame minucioso das circumstancias ensinava que uma tal Stegomyia podia ter-se introduzido perfeitamente antes de se fechar o mosquiteiro, e aproveitado para picar as horas do crepusculo da tarde ou da manhan. - N'um ambiente replecto de Stegomyias e depois de annos de observaça por pessoal exercitado methodica e especialmente dirigido sobre este quesito, e nenhum caso plenamente averiguado de inzasão provadamente nocturna n'um mosquiteiro por femea de Stegomyia, - não deixa de ser um facto significativo, que forçosamente deve impressionar!

Tanto mais deve impressionar, quando se lê no relatorio da commissão medica franceza no Rio de Janeiro textualmente: "Ce moustique s'attaque à l'homme après la chûte du jour, dans la mit et le matin avant le lever du soleil; nous l'az'ons éprouvus personellement. Il est extrêmement facile de s'en rendre compte si l'on examine le matin de bonne heure le moustiquaire d'un lit occupé par un malade, dans une salle où les Stegomyas (1) ont accès. Pour peu que cette moustiquaire ne ferme pas hermétiquement, on y trouve le matin des femelles gorgées de sang qui y ont penetré et ont piqué pendant la mit.»(2)

Como querem os illmos, doutores emissarios do Instituto Pasteur em Paris provar sob a fé da sua plena responsabilidade scientifica, que estas Stegomyias lá no Rio de Janeiro "ont piqué pendant LA xuit", quando aqui no Pará, nós, conscientes da mesma responsabilidade plenar, devemos, á vista das nossas positivas averiguações durante annos, declarar a picada nocturna como excepção?

(1) Surprehende devéras que os i!lmos. redactores do * Rapport» escrevam persistentemente e Slegomya $\$$, por todn o trabalho, quando o autor do genero, Theobald. Monograph of Culicidae, 1901, Vol. I, pag. 283 o chamou s Stenomyia , ninguem tendo o direito de substituir tal nome etymologicamente bem formado, por outra maneira de escrever. viciada e compativel de interpretaçảo toda erronea.

(2) Us gryphos são nossos. - G. 
Não negamos a possibilidade de picarem femeas de Stegomyias de noite - mas accentuamos que é indispensavelmente preciso que se encarem estas cousas debaixo do seu aspecto real e que se não insinue significação diversa da que ellas de facto possuem. Se a femea de Stegomyia pica de noite, n'um quarto illuminado - (pois nego que ella o faça normalmente n'um quarto completamente escuro) - é antes de tudo e em primeira linha simplesmente, porque ella estará illudida acerca da phase do dia: toma por dia a claridade artificial, desperta e retoma as suas occupações diarias, que culminam principalmente na procura de alimento - maxime no caso, que a caçada n'esse sentido durante o dia anterior não tiver sido acompanhada de successo.

Baseio-me n'uma observação que frequentemente tenho occasião de fazer com o Culex fatigans. Ora, este mosquito embora estrictamente nocturno, tambem é susceptivel de enganar-se pelo mesmo modo, como a Stegomyia, que é diurna. Na nossa officina photographica, que é um pequeno chalet isolado no jardim, composto de duas peças, uma exterior para copiar, imprimir, etc., outra interior para o processo do revelamento e da fixagem das chapas - esta camara obscura propriamente dita, é repleta sempre de innumeros Culex fatigans. Ficando, de dia a porta aberta, em horas quando não ha trabalho photographico para fazer, pouco ou nada se nota da presença d'estes mosquitos, que estão quietos, pousados por todos os cantos. Apenas fecha-se a porta, estabelecendo-se completa escuridão, excepto a pouca luz vermelha que vem atravez da dupla janella, principia a actividade de centenas de Culex fatigans, voando, dançando e cantando, tal qual como se fosse noite. Estou certo que identicas observações tenham sido feitas já innumeras vezes por outras pessoas, por aqui pelo Brazil fóra, ao ingresso n'uma peça onde reina escuridão.

Lavra assim o nocturno Culex fatigans, com a noite artificial durante o dia, no mesmo engano, como a diurna Stegomyia fasciata, com o dia apparente durante a noite. $\mathrm{O}$ caso é palpavelmente o mesmo. Entretanto ainda não ouvi ninguem tentar a paradoxal doutrina que a femea de Culex fatigans depois de ter chupado sangue, invertesse o seu modo de vida, tornando-se diurna!

\section{Origem e patria da Stegomyia fasciata.}

Conheço a argumentação dos autores que querem que a Stegomyia seja de origem americana; estriba-se sobretudo na relação da viagem de Christophoro Colombo. Sem querer contestar que a molestia que victimou parte da tripolação das caravellas dos conquistadores tenha, de facto, sido identica com a febre amarella, constitue isto uma prova positiva de que a mesma molestia não tenha existido antes na costa d'Africa? De certo que não. Quando muito poder-se-á objectar que falta um documento historico que nos conte da existencia da Stegomyia na Africa em tempos precolombianos. Mas da ausencia de um documento historico acerca de certo facto jamais se poderá deduzir a não-existencia do mesmo facto. Ha evidentemente muita cousa que jâ se passou n'este mundo sublunar, da qual nunca historiador humano nos deixou resenha, e que nem por isto é menos verdadeira.

Ençaremos um pouco mais de perto esta questão. A Stegomyia fasciata é, como sabemos, um mosquito affeito ás grandes cidades, aos centros populosos, do littoral e 
das regiões visinhas. Ora pergunto eu, onde estavam estas grandes cidades que os invasores europeus tivessem encontrado, no littoral atlantico desde as Antilhas até a foz do Rio da Prata? Quaes os pontos onde os indigenas americanos se tivessem condensado em populosas residencias permanentes? Não as havia e isto não nos surprehende de fórma alguma attendendo á indole e ao genio especifico do indio. $\mathrm{O}$ indigena americano foi, em todos os tempos, o que.elle é ainda hoje: ciumento da liberdade incoacta, não tendo o habito nem a tendencia para agrupar-se e concentrar-se em residencias collectivas realmente consideraveis. As suas tabas constavam de algumas duzias de casas, na maioria dos casos nem chegando a cem n'uma mesma localidade circumscripta. São antes aldeinhas do que aldeias. Comparaveis ás formigas e abelhas, o crescimento numerico sempre traz para elles como consequencia a emigração de enxames, o desmembramento. Forma-se nova taba, meio dia, um dia, dous dias mais rio acima, mais rio abaixo, mais mata a dentro, que por sua vez voltará ao estado de tapéra devido ao genio irrequieto e nomada do indio, antes que ella tenha adquirido qualquer incremento e dimensões algo consideraveis. Não são propriamente sociaveis na sua moradia: se n'elles existe o espirito da sociabilidade este se manifesta somente por occasião das festas, das emprezas bellicas, nos grandes exodos, etc. Durante taes occasiões transitorias e passageiras sim, costuma haver agglomeração de gente, mas toda aquinhoada, quando muito, em acampamento que nem provisorio se póde chamar; nem mesmo com abarracamento é realmente comparavel. Passadas estas occasiões toda a multidão se dissolve, como por encanto ou por um sopro de vento. Ora, taes cousas não são do gosto da Stegomyia fasciata.

Que vemos por outro lado na Africa? - Um dos mais frizantes caracteristicos ethnologicos da raça preta é exactamente o seu espirito de sociabilidade fortemente de sorpreza e de admiração pelo agrupamento de habitações attingindo dimensões numericas rebeldes a um recenseamento rapido. Lá se encontram frequentemente centros com 10, 15 e 20 mil habitantes effectivos, aos quaes entretanto se applica apenas a qualificação de "aldeia ». A' noção de cidade, conforme praxe africana, não correspondem senão centros que possam apresentar um multiplo de taes cifras. Eis uma situação que quadra admiravelmente com o que a Stegomyia fasciata quer e precisa. E' o optimum para as suas condições de vida: clima quente e humido, reunido a aggremiações humanas devéras importantes.

$\mathrm{O}$ que eu queria archivar em breves palavras aqui é que um confronto cuidadoso da situação ethnologica, cá e lá,-e esta certamente constitue factor de relevante importancia n'este assumpto - por sua vez depõe com vantagem innegavel em prol da origem africana da Stegomyia fasciata.

Uma outra serie de considerações em alto grao capaz de abalar a theoria, tão fraca nos seus alicerces, do indigenato americano da Stegomyia fasciata, abre-se logo que se pondera os resultados que se obtem de um exame critico da colligacao Stegomyia fasciata - Culex fatigans. Nos meus trabalhos anteriores apontei por diversas vezes - com insistencia (pags. 56,61 , etc.), para o facto de serem estes dous mos- 
quitos companheiros inseparareis por toda a parte do mundo. E demonstrei como, um diurno e outro nocturno, formam juntos uma commandita admiravelmente organisada para, em rotaça cyclica diurna, tributar a homem na zona tropical o seu sangue.

Ora, convém saber que o exemplar-typo, o original que serviu para a primeira descripção do Culex fatigans, de Wiedemann em 1828, veio das Indias orientaes (1). Esta circumstancia, embora por si só não constitua uma prova plena, não deixa de ter importancia symptomatica.

Pergunto eu, esta ominosa commandita culicidea, Stegomyia fasciata e Culex fatigans, datará de hontem, será um producto casual talvez da parte tropical do Novo Mundo? Julgo que ella é de data muito mais remota e que devemos procurar o solo onde o pacto se celebrou, em qualquer parte do Velho Mundo e que elle não é casual, mas sim a consequencia natural de uma identidade bastante grande de interesses communs.

Opino que ha bons argumentos para admittir uma patria ethiopico-indica para esta alliança. E cada vez mais desejavel se me afigura uma investigação conscienciosa e criteriosa sobre a questão de um eventual parallelismo entre a distribuição e dispersão antiga e moderna da raça preta humana por uma parte, e dos dous mosquitos contrahentes da denunciada alliança offensiva por outra.

Indispensavel é não perder de vista que mal avisado iria quem se deixasse impressionar e influir unilateral e parcialmente pelo aspecto que hoje em dia as cousas apresentam n'este terreno. Quer-se ter um exemplo? Não é preciso ir muito longe para encontrar um bem drastico: O Brazil é hoje o maior productor de café e indubitavelmente é tambem desde muito, o paiz, onde haverá a maior parte de pés de cafeeiros plantados. Supposto agora uma vez por um momento o caso do completo desapparecimento de todos os documentos historicos, (por uma catastrophe tellurica), que testemunham a origem asiatica do caféeiro e a sua introducç̃o no Brazil, via Cayenna, quem procuraria a patria d'este arbusto na Arabia? - E não é facto veridico, que esta lembrança historica sensivelmente tende a empallidecer já na consciencia popular, aqui no Brazil, com o crescente intervallo de tempo que nos separa do momento da introducção, que entretanto não jáz mais de dous seculos atraz de nós?

\section{6. - Taeniorhynchus fasciolatus Arribalzaga (1891)}

(Mosquito adulto, alado; reja nossa Estampa colorida II, fig. 6, femea $\%$; fig. 7 , macho む (2); ovos, larva e seus pormenores Est. G, figs. $64-72,74-79$ e 81 ).

No meu primeiro trabalho de 1902, cap. I, pag. 9, tratei summariamente d'este mosquito crepuscular, assaz frequente no Pará o no baixo Amazonas, frizando desde 
então os seus caracteres exteriores, pelos quaes poderá ser reconhecido a olho nú. A estes se deverá accrecentar ainda, como um dos diagnosticos dos mais certeiros, o annel branco-alvo sito proximamente á articulação distal do femur em todas as 6 pernas, - pormenor este muito bem visivel nas nossas figuras coloridas, com maximo cuidado e esmero executadas sobre exemplares vivos e frescos.

Foi já colleccionado este vistoso Culicideo na Ilha de Trindade - , na Guyana Ingleza -, no baixo Amazonas (Austen, Durham) -, no Pará (Durham, Goeldi) (1) -- Rio de Janeiro (Moreira, Goeldi) - São Paulo (Lutz) - Buenos Ayres, provincia (Arribalzaga).

Até 1902 nada se sabia do desenvolvimento d'esta, nem de qualquer outra especie do genero Taeniorhynchus, até que em setembro d'este mesmo anno consegui esclarecer palo menos as primeiras phases - ovo e joven larva. Dei uma primeira noticia provisoria em nota adicional ao meu anterior trabalho, Cap. Biologia, pag. $20 \mathrm{e}$ por carta communiquei os traços essenciaes, accompanhados de alguns esboços ligeiros a lapis, ao prof. Theobald em Londres, que d'elles deu por sua rez noticia no Vol. IV, (supplementar) da sua monumental «Monograph of Culicidae» 1903, pag. 257 e 269.

\section{Ovo.}

Devo referir-me, quanto ao geral, á minha nota anterior no baixo da pag. 20 .

Quanto á postura dos ovos de Taeniorhynchus fasciolatus e seus preliminares extraio do meu diario de observações em 1903 os seguintes dados: Com femeas, apanhadas no mato, durante os mezes de julho a setembro, chupando sangue, e tratadas no laboratorio, em gaiolas, com o mesmo alimento (sangue humano e de cobaya), consegui posturas em 25 casos diversos, cuja publicação em extenso, como eu fiz em trabalho anterior relativo ao Culex fatigans e á Stegomyia fasciata, exigiria mais espaço e tempo do que disponho n'este momento. Direi entretanto que, durante a alludida campanha de 1903, o total de femeas vivas d'esta especie de Taeniorhynchns, submettidas a ensaios de criação, attingiu a 170 individuos. Pela comparação d'estes dous numeros se verifica logo que o Taeniorhynchus fasciolatus não se presta muito facilmente a estas experiencias, pois a proporção de femeas que procederam á sua procreação no captiveiro com as que entraram nas gaiolas foi approximadamente a de $1: 7$. Morrem com muita facilidade embora não se recusem a acceitar alimento sanguineo; notei que as 2 femeas com a maior duração de vida foram uma com 11 dias apenas, outra com 9. Escolho aqui uma amostra de taes experiencias sómente: em 19 de julho de noite recolheu-se para a gaiola uma femea de $T$. fasciolatus, que na residencia directorial se tinha enchido de sangue humano, a esta juntaram-se mais 22 femeas, apanhadas em 20 de julho, nas matas de Murutucú, algumas repletas de sangue humano e todas ellas presas em flagrante intenção de fazel-o. Quatro entre ellas acceitaram sangue humano novamente no mesmo dia 20 e provarelmente exemplares, que não tiveram occasião de saciar-se em estado de liberdade. No dia 25 de julho de manhan appareceram 3 fios de ovos, com 60,63 e 60 ovos respectivamente, depois de um intervallo de 5 para

(1) Outras localidades amazonicas e guyanezas onde este mosquito foi colleccionado pelo pessoal do nosso ifuseu, são Obidos, - Prainha, - Arayollos, - Oyapoc, - Amapá. 
6 dias desde a ultima ração de sangue. (1) No dia 27 de julho finalmente appareceu mais um fio, contendo 60 ovos, com intervallo de 7 dias. Das 4 femeas nenhuma sobreviveu mais de horas ao acto da postura. Das respectivas larvas notei as primeiras no dia 29 de julho, o que dá um intervallo de 4 dias desde a postura.

Sobre outros casos refere esta synopse:

Tempo decorrido entre ultima ração de sangue e a postura dos ovos:

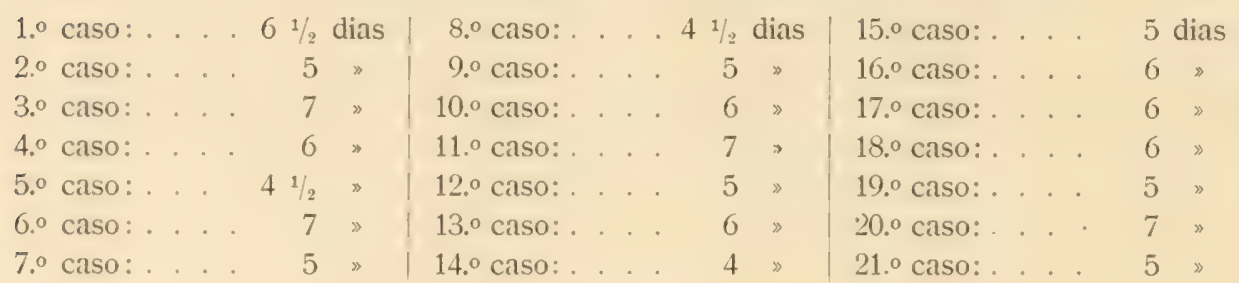

Tempo decorrido entre a postura dos ovos e o primeiro apparecimento de novas larvas:

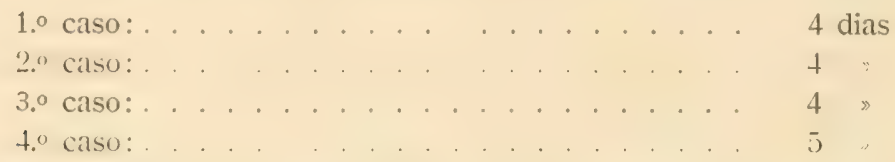

Resulta d'ahi que a média para o intervallo entre a ultima ração de sangue e o apparecimento da postura do fio de ovos no Taeniorhynchus fasciolatus costuma ser $5 \mathrm{1} / 2$ dias; a do intervallo da postura dos ovos e o primeiro apparecimento das noras larvas 4 1/2 dias. Comparando estes valores com aquelles que eu dei á pag. 46 do meu 2.0 trabalho, temos:

\section{Ovos.}

Culex fatigans ..... 3,5 dias

Stegomyia fasciata . . . . 3,7

Taeniorhynchus tasciolatus . . 5,5

\section{Larvas.}

Culex fatigans . . . . 1,8 dias

Stegomyia fasciata .... 4,5

Taeniorhynchus fasciolatus . . 4,5 "

D'este confronto parece resultar, que o Taeniorhynchus fasciolatus, - que na sua indole é um mosquito innegavelmente sylvestre embora venha, nas horas crepusculares, frequentar as casas, - tenha um desenvolvimento relativamente mais lento, que o das outras especies, que sabemos ser verdadeiras pestes domesticas. Quanto d'esta lentidão dleveria ser posto na conta de erentuaes effeitos desfavoraveis e retardativos de condições exteriores anormaes não podemos, na verdade, precisar com a exactidão de-

(1) Seja dito de passagem, que fiz as mesmas experiencias, que empreguei em Stegomyia fasciata e Culex fatigans (veja segundo trabalho), para averiguar a influencia do sangue sobre a postura dos ovos e a duração da vida $\mathrm{em}$ comparação com outros alimentos, tambem com diversas outras especies de Culicideos sylvestres, assim como 0 T. fas. ciolatus. Quatro femeas de T. fasciolatus entradas em 25 e 28 de agosto respectivamente, tratamento com mel e agua. mor:eram depois de $1,3-1,5$ dias respectivamente, sem deixar postura alguma. De duas outras. entradas em $1.0^{\circ}$ de setembro, tratadas com succo de carne fresca, morreu a ultima em 15 de setembro, não tendo deixado prole nem uma, nem outra. 


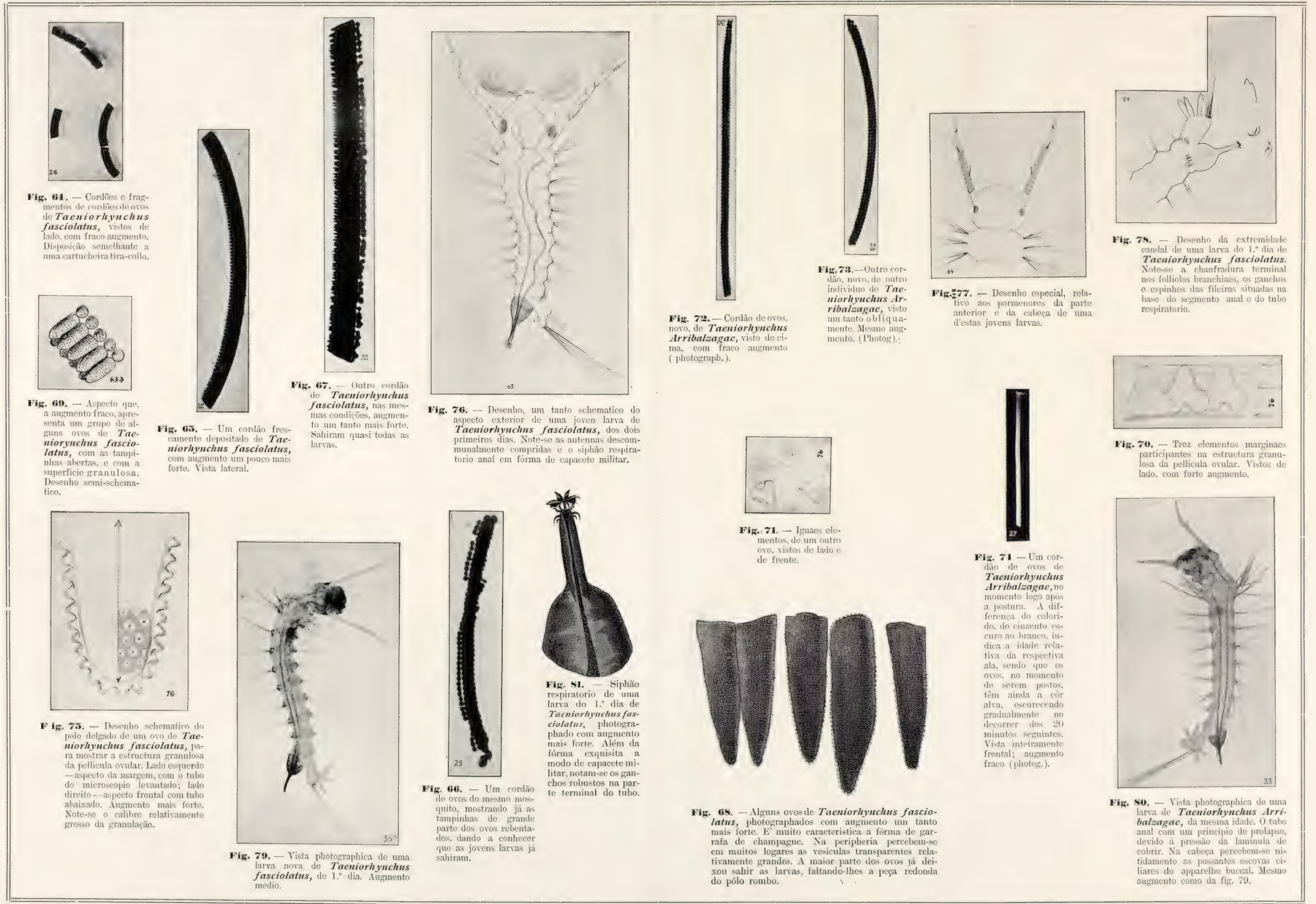

Taeniorhynchus fasciolatus - T. Arribalzagae. (iFig. 64-71; 75-79; 81). 
sejavel, mas tambem não creio dever attribuir tudo a uma possivel fonte de erros inherentes a uma pesquiza artificial de laboratorio.

\section{Ovo.}

Dimensões do oro: $0,68^{\mathrm{mm}}$ de comprimento (valor médio de 3 ovos medidos) e $0,14^{\mathrm{mm}}$ (valor médio de 6 ovos medidos).

Como demonstram as nossas figuras $64,65,66$ e 67 , os oros de Taeniorhynchus fasciolatus são depositados em fios compridos, de dupla serie, comparaveis a uma cartucheira de tira-collo, como usam os Boers. A figura 64 dá uma vista photographica, com augmento muito fraco. Naior um tanto é a ampliação das tres outras vistas. Nas figuras 64 e 65 o fio representado é ainda todo fresco. Diverso o caso nas figuras $66 \mathrm{e}$ 67 , onde pelas tampinhas pelo lado de fóra se advinha que as jovens larvas já sahiram da respectiva casca ovular. (Veja o esboço fig. 69). Todas estas figuras representam o fio em vista latteral.

A fórma do ovo de $\mathrm{T}$. fasciolatus é a de uma garrafa de champagne ou de um pão de assucar, como ensina a nossa figura 68 , que dá uma vista photographica de alguns ovos com augmento maior. A côr é um fuliginoso escuro, que com a idade e na casca vasia costuma ceder a um amarellaceo côr de ambar.

Examinando a estructura exterior da pellicula ovular, recorremos ás nossas figuras explicativas 75,70 e 71 . A primeira representa a ponta delgada de um ovo, visto com mais forte augmento. Nota-se que a margem toda é guarnecida de elementos, relativamente grandes, transparentes, verrugosos, iguaes entre si, contiguos uns aos outros, e de uma fórma caracteristica mammillar assíz diversa da dos existentes nos ovos dos mosquitos anteriormente tratados. As figuras 70 e 71 são destinadas a orientar sobre os pormenores d'estes elementos, 'com augmento assáz forte. Na vista lateral assumem, aqui e acolí, um aspecto por assim dizer cordiforme; o aspecto frontal de cima dá um disco com um diminuto circulo ao centro, correspondente á projecção da ponta do mammillão. Pela pressão sobre o cobra-objecto estes elementos podem ser separados do substrato e isolados. Na figura 75, a metade direita, dá idéa do aspecto d'esta estructura, na vista frontal, com o tubo do microscopio levantado.

Em somma, são facilmente reconhecidos os ovos de Taeniorhynchus fasciolatus por muitas particularidades.

Os fios fluctuam sobre a agua com o lado convexo para baixo, ficando os ovos d'est'arte em pé, como no caso do Culex fatigans. Só posteriormente elles se deitam sobre o lado, rompendo-se o fio finalmente depois da sahida das larvas.

\section{Larva.}

E' muito caracteristica a larva nova de T. fasciolatus. Convidamos o leitor a apreciar as nossas vistas microphotographicas de duas larvas do $1 .{ }^{\circ}$ dia, fig. 79 e 80, (esta ultima aliás relativa á joven larva de T. Arribalzagae), feitas com augmento regular, bem como o esboço, na verdade muito schematico da fig. 76. Um distinctivo dos 
mais salientes são as antennas extraordinariamente compridas, como as não vi ainda $\mathrm{em}$ larva culicidea alguma. (fig. 77) Depois é o siphão respiratorio anal, que assume feitio descommunal, tendo a fórma de um capacete militar (figs. 79, 76, 78) - uma campana semi-espherica na base, sobremontada de um tubo cylindrico antes tenue. Na extremidade livre d'este siphão (fig. 81) é um circulo de singulares ganchos relativamente fortes, que lembram os anzóes compostos para a caça dos crocodilios e os projectis compostos empregados na pesca moderna das baleias, e que se abrem a um momento dado.

Pela fig. 78 fica-se inteirado acerca dos pormenores dà região anal da larva.

No pecten tem uma fileira transversal de umas poucas escamas em forma de ganchos denticulados. Os folliolos branchiaes, de um oval lanceolado, possuem na ponta arredondada distal um pequeno entalhe. Forte tufo de cerdas compridas guarnece o canto interior do mesmo segmento anal; fórtes cerdas notam-se tambem ao longo do corpo, mormente na região thoracica. Infelizmente esqueci então em 1903 de orientar-me devidamente sobre o habitus da placa labial, e hoje não tenho mais á mão o material necessario para fazel-o.

Com pezar registro aqui o infortunio que tive, em criar as larvas de Taeniorynchus fasciolatus atravez de todo o cyclo de desenvolvimento. Nunca consegui conservar vivas as novas larvas além de uns 3 , no maximo 4 dias; depois morrem sempre com uma regularidade irritante. (1) Não podemos assim apresentar desde já esclarecimentos relativos á larva adulta e á chrysalida d'este mosquito. Todavia esperamos preencher ainda esta lacuna, aperfeiçoando-se o methodo da criação artificial por um lado, e dando maior desenvolvimento ao colleccionar das larvas culicideas sylvestres nos seus escondrijos naturaes por outro.

\section{7. - Taeniorhynchus Arribalzagae Theobald (1903),}

(Mosquito adulto, alado, veja a nossa Estampa colorida II, fig. 8 (femea 우), fig. 9 (cabeça do macho む). - Ovos e seus pormenores. (Est. G, figs. 72, 73, 74; 80).

Esta especie de mosquito, limitada ao baixo Amazonas, é toda nova, pois sómente no anno passado foi descripta pelo prof. Theobald no Vol. IV (Suppl.) da "Monograph of Culicidae» pags. $261-263$ sobre exemplares colleccionados no Pará pelo Dr. Durham, da commissão medica ingleza que aqui esteve estudando a febre amarella. Novo material proveniente do Pará e seus arredores foi enviado por mim ao mesmo eximio especialista, estando eu de posse de exemplares identificados por elle (co-typos) ainda antes da publicação do mencionado volume supplementar. Limitando-se o autor em dar apenas alguns esboços relativos ás escamas, e tendo faltado assim até agora figura do habitus exterior d'este mosquito na litteratura scientifica, a nossa estampa vem inquestionavelmente preencher uma lacuna.

(1) Esta situaçân nos faz lembrar as bellas palavras de Réaumur, com as quaes o illustre naturalista inicia o capitulo sobre o *Cousin piquant * nos seus admiraveis \& Mémoires pour servir à l'hístoire des insèctes *:

* Les cousins sont nos ennemis déclarés, et des ennemis trés-fàcheux. Mais ce sont des ennemis bons à connaître ..... il y a même tel moment de leur vie où, après avoir fait oublier à l'observateur qu'ils le persécuteront un jour, il tui font ressentir des inquictudes pour leur sort $n$. 
Este mosquito tráe á primeira vista já seu proximo parentesco com a especie anterior. Participa com ella tanto na posse da fita clara na tromba, como na do anel claro, luzente como madreperola, na parte distal da forma de todos os 6 pares de pernas. A differença para com o $\mathrm{T}$. fasciolatus reside principalmente no colorido ruivobruno uniforme do thorax e na ausencia de ornamentos claros na margem e nos lados dos segmentos abdominaes.

Tambem nos seus costumes o T. Arribalzagae é fiel aparentado e companheiro do T. fasciolatus. Entre as cólheitas de mosquitos sylvestres viros provenientes das matas de Murutucú e outros arredores da cidacle de Belem rem individuos de ambas as especies misturadas. Todavia apparece o T. Arribalzagae entĩo representado na minoria e tambem não estende tão facilmente as suas excursões crepusculares até a peripheria da cidade. Procura picar na penumbra da mata sombria durante o dia, da mesma fórma e de sociedade com o T. fasciolatus.

Parece que até agora não foi colleccionado este mosquito, senão pelo mencionado Dr. Durham e o pessoal do nosso Museu, e por ambos sómente nos arredores do Pará. Raro não é, como bem prova a circumstancia de eu ter tido a disposição para as minhas experiencias, durante a nossa campanha em 1903 nos mezes de Agosto até Novembro nada menos de 44 femeas vivas. Em 7 casos obtive criação, o que novamente corresponde de perto á proporção de 1:7. Escolho outra vez um caso instructivo dentro dos annotados no meu diario de observações.

Entrando 2 femeas de T. Arribalzagae no dia 26 de Outubro de 1903, uma tomou sangue de cobaya no dia 27. Morreu uma no dia 30 de Outubro, ficando uma sómente. Esta acceitou sangue no dia 4 de Novembro, todavia não se enchendo de todo. Tomou ainda sangue nos dias 9 e 11 de Novembro. Appareceu um fio de 42 ovos no dia 21 de Novembro e tendo a femea tomado uma ração de sangue de cobaya ainda uma vez em 23 de Novembro, appareceu na bacia d'agua no dia 4 de Dezembro um fio regular de $2 \times 38=76$ ovos. Morreu n'este mesmo dia, tendo durado nada menos de 38 dias no captiveiro - o que considero um caso de todo excepcional. Larvas só alcancei 4 vezes.

Intervallo entre ultima ração de sangue e postura dos ovos:

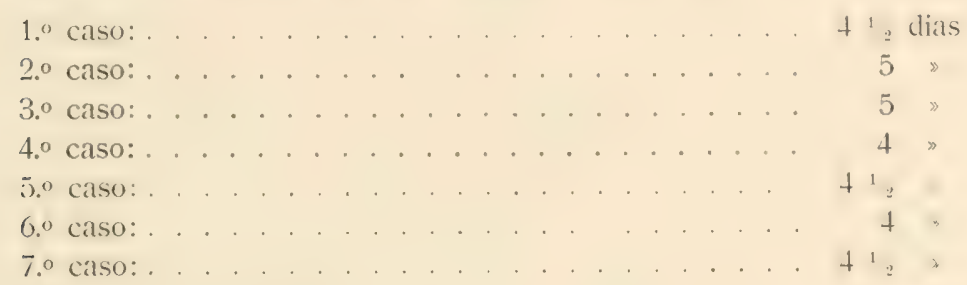

Intervallo entre postura dos ovos e primeiro apparecimento de larvas:

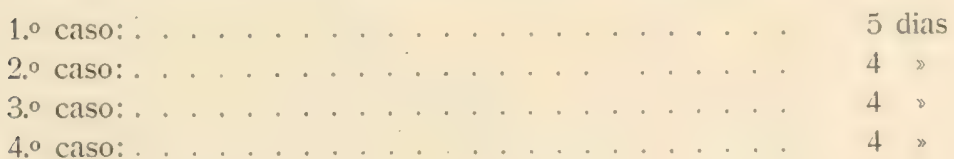


D'ahi resultaria na média um intervallo de $4 \frac{1}{2}$ dias entre a ultima ração de sangue e a postura dos oros, e de $4 \frac{1}{2}$ dias para a sahida das novas larvas desde a postura dos ovos. Tivemos adiante:

T. fasciolatus: ovos $-5,5$ dias; larvas - 4,5 dias;

e agora T. Arribalzagae: ovos - 4,5 dias; larvas - 4,25 dias.

E' bem possivel que n'essa serie maior de experiencias o valor do primeiro intervallo tenderia a augmentar, approximando-se assim então mais dos valores indicados para T. fasciolatus. Em todo caso fica ainda d'esta vez de pé um lapso de tempo maior para estas duas primeiras phases de desenvolvimento de mais este Culicideo genuinamente sylvestre, em comparação com as médias para Culex fatigans e Stegomyia fasciata, mosquitos domesticos declarados.

\section{Ovo.}

Semelhança tamanha entre os mosquitos alados faz suppor de antemão semelhança não menor nos ovos e nas larvas. De facto não posso distinguir entre ovos e larvas de especie anterior e oros e larvas de T. Arribalzagae. Referem-se a esta especie as nossas vistas photographicas (figs. $72,73,74$ e 80 ). Os fios, numero, fórma e tamanho e aspecto dos ovos, tudo é identico, tanto que poderiam ser tão bem de uma como de outra.

Na figura 74 vê-se um fio inteiramente fresco, mostrando ainda a côr alva da porção mais nova, ao passo que o colorido vae escurecendo com a approximação da parte opposta que foi posta a primeira. Tambem partilham as larvas de T. Arribalzagae (fig. 80 ) da mesma fragilidade, como as de T. fasciolatus. Nunca consegui crial-as além de 4 a 5 dias de edade.

Não sei dizer onde moram as larvas, no seu estado livre, na natureza. Futuras pesquizas hão de trazer luz n'este problema.

\section{8. - Taeniorhynchus fulvus Wiedemann (1828).}

(Veja Estampa H.: fig. 82: femea pondo; figs. $83-87$ : ovos e seus pormenores).

Lastimo que a adversidade de um accaso não tivesse permittido de incluir uma figura colorida d'este grande, devéras bello e notavel Mosquito, descripto desde muito tempo, embora deficientemente. Do original, incompleto em suas extremidades, não se conhecia a proveniencia exacta, que é a região amazonica e as Guyanas. Uma serie de exemplares frescos, por nós enviados d'aqui ao prof. Theobald, em Londres, deu a este excellente profissional ensejo dara completar a diagnose e eliminar as lacunas e os defeitos da descripção original, como se vê pelo Vol. IV (supplementar) pags. 25̃7-25̃8.

E' entre os nossos mosquitos uma das especies mais volumosas. Caracterisa-se além do seu tamanho distinctamente pelo bello colorido geral amarello; côr de ouro, que se estende sobre todas as partes, inclusive boa parte da margem anterior das azas, contrastando aqui na aza com a margem distal, que é occupada por uma distincta 


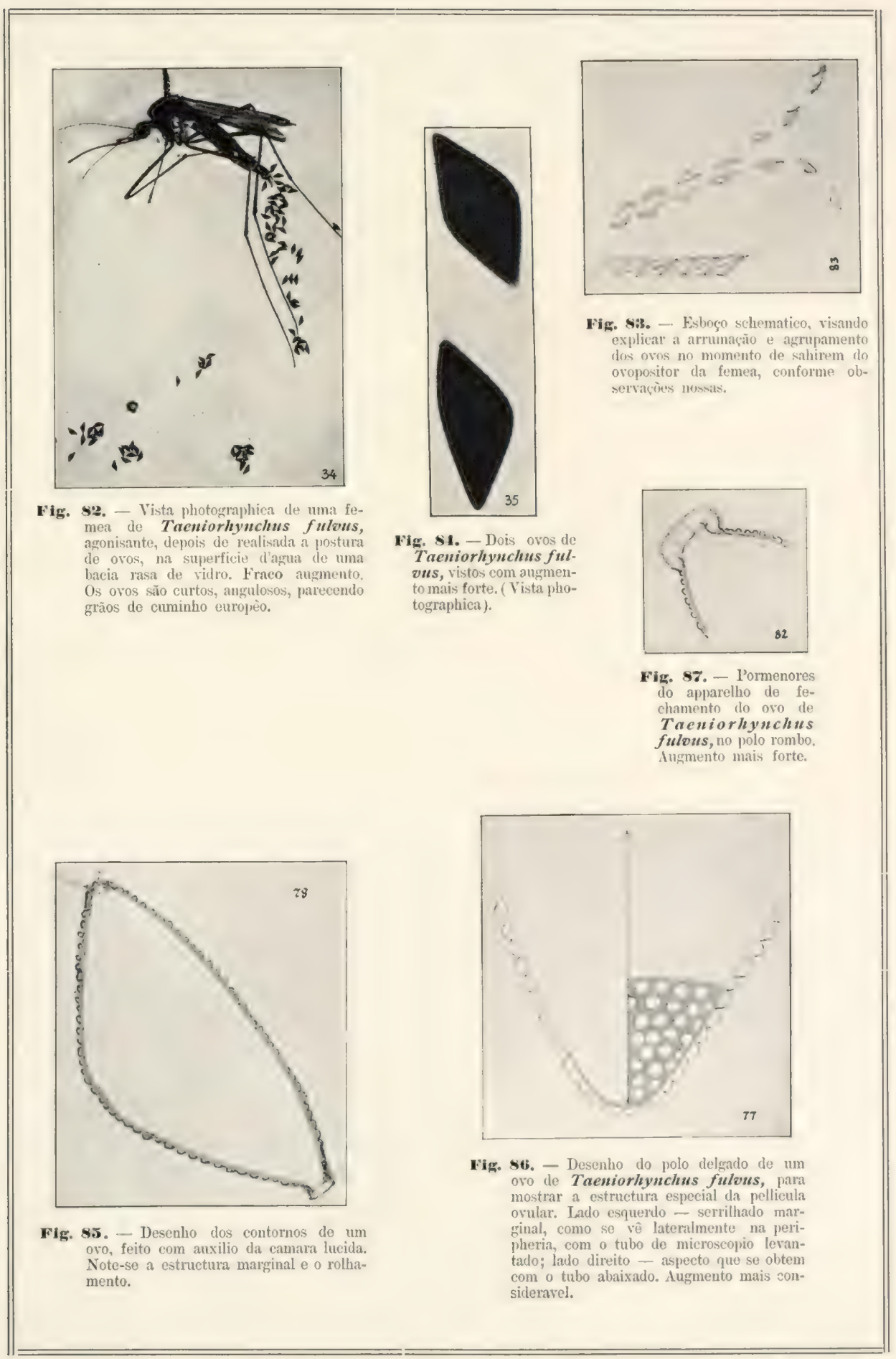



mancha ennegrecida, ao passo que o restante brilha em bellissimo effeito iriante. Como pretas destacam-se tambem ostensivamente as articulaçðes mediaes de todos os 6 pares de pernas, os tarsos, a ponta da tromba e a dos palpos. O dorso do thorax e a margem posterior dos anneis abdominaes tambem deixam ver certas zonas de uma tinta um pouco diversa, mais escura do que o bello amarello dourado geral. O exemplar original de Wiedemann (Culex fulvus) traz como proveniencia simplesmente «Brazil ». - O exemplar, descripto depois por Walker com o nome de Culex flavicosta, reexaminado e descripto por Theobald e conservado no British Museum, é indicado como tendo vindo da "Região amazonica". Um exemplar na collecção Bigot declara simplesmente "Tropical ?", nem ao menos transparecendo qual das partes do mundo devia ser considerada como patria.

No baixo Amazonas (Pará e arredores) tem sido nos ultimos annos colleccionado por Durham e Goeldi, em muitos exemplares. Um exemplo encontrei ultimamente n'uma colheita de mosquitos, feita por nossa incumbencia, pelo preparador da secção entomologica, Snr. Adolpho Ducke, em Tabatinga. Foram tambem recentemente colleccionados individuos d'esta especie na Guyana Ingleza. - Obvio é, que nada constava absolutamente do modo de vida do Taenorhynchus fulvus. Podemos dizer que os nossos exemplares foram apanhados de preferencia em derrubadas novas e capoeiras, cercadas de mato alto, no Murutucú, e sempre de dia. Ao atravessar, em horas calidas e ao sol ardente, taes clareiras no mato, esse mosquito mostra-se para o excursionista e caçador, impertinente e pica severamente.

\section{Ovo.}

Uma femea de T. fulvus, apanhada no Murutucú, repleta de sangue humano, no dia 16 de Julho de 1903, entrou em gaiola separada de criação, enchendo-se novamente de sangue humano no dia 19 , ás 9 1/2 h. a. m. Na manhan do dia 24 foi encontrada boiando agonisante no espelho d'agua da bacia de vidro, tendo diante de si uma postura de 78 ovos, singularmente arrumados e exquisitamente conformados. Vejam-se as nossas figuras $82-87$.

O arranjo dos ovos é visivel pela fig. 83. Reunidos dous a dous apparentemente, com o lado largo, em figura de losango, - estes novamente encostados uns aos outros, nasce o fio do ovipositor. Mas em vez de ficarem reunidos, desagregam-se por um lado os losangos, para logo se afastarem tambem os dous ovos de cada losango e tomar cada um rumo proprio e independente.

Dimensões: $0,498^{m m}$ de comprimento (valor médio de 4 oros) e $0,29^{m m}$ de largura (valor médio de 4 ovos).

Devéras exquisita, fóra do commum, é a fórma do ovo, como se vê pelas figuras $82,84,85$. São curtos e largos a mesmo tempo, no seu conjuncto offerecendo o aspecto de grăos de cuminho. O lado bojudo, convexo é a face dorsal; o quasi plano é a face ventral. $O$ ovo inferior na fig. 84 corresponde á fig. 85 na sua posição lateral. $\mathrm{O}$ ovo superior da mesma fig. 84 porém assume posição dorso-ventral. Seu colorido é um negro retinto.

Quanto aos pormenores da estructura exterior da pellicula ovular orientam cabalmente as nossas figuras 85,86 e 87 . A margem mostra uma grảnulaçĩo composta de 
elementos transparentes arredondados, iguaes entre si, e relativamente grandes. Levantando o tubo do microscopio, o aspecto frontal da superficie do ovo é como o mostra a metade direita do nosso desenho (fig. 86) representando o polo delgado visto sob augmento maior. Nåo deixa de dar na vista o mechanismo de rolhamento do ovo, no polo opposto, rombo, (veja fig. 87): E' largo e chato.

\section{Larva.}

Infelizmente gorou a criação toda; não consegui obter uma larva sequer, de maneira que me vejo na impossibilidade de informar desde já a seu respeito. Provarelmente tambem a larva de $T$. fulvus nos reserva surprezas.

Se tomassemos por criterio o agrupamento, a fórma e o tamanho do ovo para decidir acerca da posição systematica do Taeniorhynchus fulvus, evidentemente razões de sobra haveria para duvidar de que a collocação d'esta especie ao lado de. T. fasciolatus e T. Arribalzagae fosse acertada. Lá temos duplos fios de ovos estirados, em fórma da garrafa de champagne; aqui encontramos ovos soltos, curtos e largos com a fórma de grãos de cuminho. O agrupamento inicial dos ovos em fio do T. fulvus (que aliás tem organisação inteiramente diversa) no momento da postura, é uma phase transitoria de tão curta duração, que não se póde ver n'ella senão, quando muito, uma pâllida lembrança do fio solido em fórma de cartucheira das duas outras especies dos mencionados Taeniorhynchus. Supponho, que tambem a larva será mais ou menos diversa. Creio não me enganar, suppondo que cêdo se reconhecerá a necessidade de remover esta nossa especie para um novo genero, eliminando-a da communhão de fórmas agrupadas ao redor do Taeniorhynchus fasciolatus e T. Arribalzagae. Aliás já o tamanho avantajado do mosquito adulto, o colorido sui generis, além de diversas outras particularidades bem notaveis, nos levam a augurar para este distincto Culicideo paraense uma posição systematica em genero separado. N'esta emergencia o novo nome de Chrysoconops não assentaria mal ao futuro genero chefiado pelo actual $T$. fulvus.

\section{9. - Mansonia (Panoplites) titillans Walker (1848)}

(Mosquito adulto, alado veja Estampa colorida III, fig. 11, femea; fig. 12, femea, de lado, em posição de repouso; fig. 13, macho (1); ovos e os seus pormenores. Est. J, figs. $88-92$ ).

Outro mosquito crepuscular aqui do Pará, a tal ponto semelhante, em habitat, costumes e aspecto, ao Taeniorhynchus fasciolatus que, para saber-se ao certo a qual das duas especies pertence um individuo capturado, será, por via de regra, preciso re-

(1) Tambem o macho d'esta especie nunca foi, ao que eu saiba, figurado por autor anterior. Theobald Pl. 30 dá sómente a femea. 


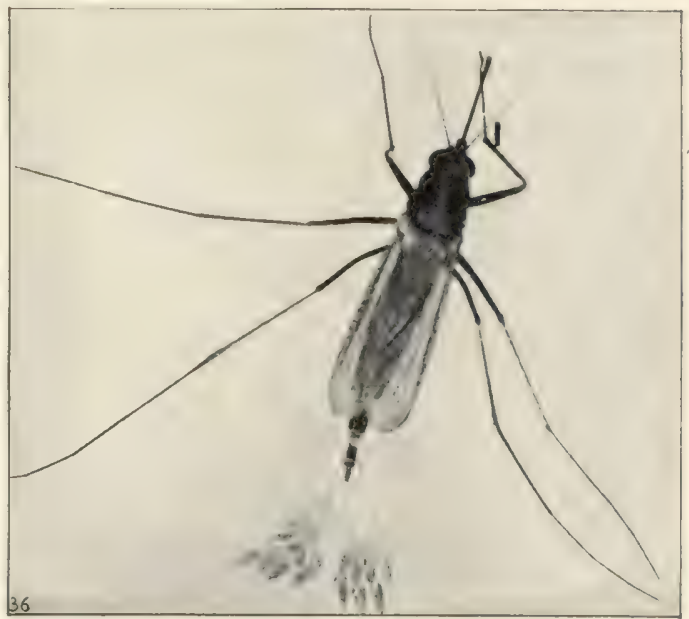

Fig. ss. - Femen de Mansonia titillans, vista the cima, no principio da postura dos seus ovos, na superficie da arua, n'uma bacia rasa de vidro. O ovopositor muito protruso, os ovos mais novos ainda alros, os mais antigos assumindo colorido já mais escuro. Fraco aurmento.
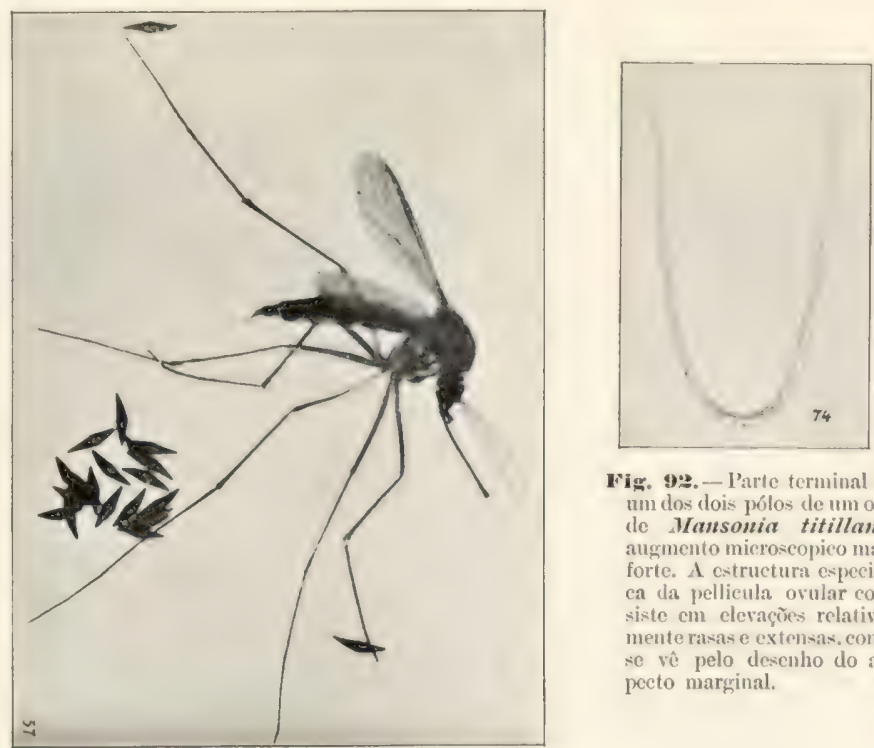

Nig. 9:- Parte terminal de mundos dois pólos de um ovo de Mansonia titillans, angmento microseopieo mai forte. A cstructura especifiea da pellicula orular consiste em elevaçòes relativamente rasas e extensas. como se vê pelo desenho do as. pecto marginal.

Fig. s9, - Femea de Mansonia titillans, agonisante depois de ter terminado a sua postura de ovos. Uma partida de oros no seu agrupamento natural. Mesimo augmento que na fig. 88.

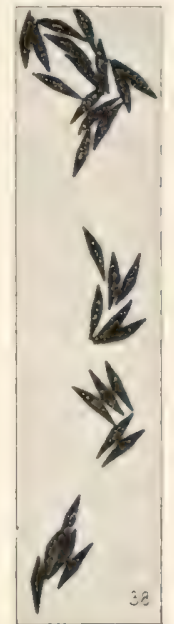

Fis. 90, - Agrupamentos naturaes de ovos de M/rn sontia titillans, pouco tempo depois da postura, na stuperficie da baeia de observaçio. Mesmo auğ. mento.

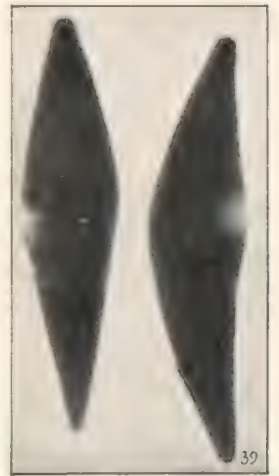

Vig. \$1. - I)ois ovos de Mansonia titillans, vistos com augmento mai forte. Vote-se a sna fóm earacteristica: dois eone muito estirarlos. reunidos pelabase. 

correr ao vidro de augmento. Na verdade, uma vez reconhecido, encontram-se differenças golpeantes que um confronto entre as nossas figuras respectivas nas Estampas III e II melhor ensinará do que um longo commentario. Dous são entretanto os distinctivos que á primeira vista permittem reconhecer individuos da especie Mansonia titillans: as grandes escamas escuras, que emprestam ás azas um aspecto singularmente sombrio, e que fazem parecer como que preto o mosquito, quer voando, quer em repouso; em segundo logar a ausencia d'aquelles anneis claros, na femea, perto da articulação distal, que são substituidos na Mansonia por uma multidao de salpicos amarallaceos em campo brunaceo. Mansonia titillans tambem vem frequentar, ao cahir da noite, as casas aqui no Parí na peripheria da cidade, (1) entremeando com individuos de Taeniorhynchus fasciolatus; entretanto apparece menos frequentemente. Na mata humida e sombria ataca todavia o transeunte mesmo de dia claro, como aliás é costume de quasi todos os Culicideos haematophagos nocturnos que eu conheço.

Esta especie tem sido colleccionada: na Guyana Hollandeza e Ingleza; nas Ilhas Trindade, Jamaica e Antigua; no Parí e baixo Amazonas (Durham, Goeldi); (2) no Rio de Janeiro (Lutz, Moreira, Goeldi).

Ha ainda duas outras especies assaz parecidas: Mansonia pseudo-titillans Theobald (1901), do baixo Amazonas (Austen), caracterisado por não ter senão as typicas escamas largas de Panoplites ao longo das veias e II. amazonensis Theobald (1901), igualmente do baixo Amazonas (Austen; Goeldi), notavel pela sua ornamentação dourada da parte anterior do thorax.

Muito caracteristica para a Mansonia titillans é a predilecta posição que assume no repouso, a qual se acha figurada na fig. 12 da nossa Est. III. Compare-se a fig. 2, Est. I, de uma Stegomyia femea, em repouso. Em vez de separar o par de pernas do meio do das posteriores e de levantar este ultimo em curva livremente para o ar, a Mansonia junta estreitamente a parte femoral dos tres pares de pernas, e emquanto o resto do primeiro par é então dirigido para a frente, conservam-se em estreita juncção o resto do $2 .^{\circ}$ e $30^{\circ}$ pares, dirigidas para traz, tocando no chão. Ganha assim a femea de Mansonia um exquisito aspecto anguloso, inteiramente desusado entre outros mosquitos, e que sempre me impressionou. Convenci-me de que ella facilmente consegue passar desapercebida n'essa posição em que se faz de pequena e enroscada, e não hesito em reconhecer ahi um artificio e manobra de mimetismo.

Muito pouco se sabe até agora do cyclo de desenvolvimento nas diversas especies do genero Mansonia (antes Panoplites). Em 1901, no Vol, I da sua obra o professor Theobald deu na pág. 22 (fig. 14) uma illustração de ovos que elle declara serem os de um Panoplites da Africa Central, sobre a autoridade do Dr. Daniels. Recentemente, 1900, elle poude accrescentar Vol. IV (supplementar) pag. 270 uma microphotographia de uma chrysalida da mesma Mansonia uniformis de Theobald, fornecida pelo Dr. Low. Eis ahi tudo que consta até hoje relativo a este assumpto.

(1) Conforme o meu segundo trabalho "Resumo, etc. » pag. 64 da (da ediçào original) e pag. 82 desta re-

(2). Outras localidades amazonicas e guyanezas, onde esta especie de mosquito, foi colleccionada pelo pessoal do nosso Museu, são: Obidos, - Alemquer, - Paraná do Paranaquára, - Prainha, - Arrayollos, - Rio Xingú, - Faro, - Teffé, - Rio Japura, - Tabatinga, - Rios Purís e Acre, - Amapá.
} 


\section{Ovo.}

Nos mezes de agosto, setembro e outubro de 1903 fiz experiencias com 5 femeas vivas de Mansonia titillans. (1) Uma que tinha sido apanhada na residencia directorial, ao cahir da noite, ao jantar, no dia 31 de agosto, foi encontrada pondo na manhan do dia 3 de setembro. (fig. 88 e 89 ). A postura quando terminada constou de uns 50 ovos. A's $10 \mathrm{1} / 2$ h. ${ }^{2}$. ". . O numero d'elles ainda não passava de 6 ; poude assistir ao acto com o vidro de augmento. Do ovopositor muito distendido vi-os nascer um por um, brancos ainda no principio, escurecendo porém regularmente depois de 15 a 20 minutos. Uma observancia de uma lei de agrupamento especial não pude reconhecer; reunidos a principio ainda, como ao acaso, em grupos maiores e menores, affastaram-se fluctuando, entregues ao seu destino pessoal e individual,

Dimensões do ovo: $1,029 \mathrm{~mm}$. de comprimento (valor médio de dous ovos medidos) 0,29 mm. de largura (valor médio de dous ovos).

O ovo de Mansonia titillans, positivamente grande, pois attinge a mais de $1{ }^{\mathrm{mm}}$, é caracterisado por uma fórma, que eu poderia comparar a dous cônes bastante estirados, unidos pela base. (figs. $89,90,91$ ). A proporção entre o eixo longitudinal e o transversal, que é um pouco mais de $3: 1$, explica que o aspecto do ovo é singularmente estirado. Quanto aos contornos elle se apresenta francamente anguloso, podendo-se dizer que são feitos na sua essencia de 4 linhas quasi rectas ou pelo menos muito fracamente curvos. O maior diametro é ligeiramente dislocado do meio ficticio para o lado do pôlo rombo, um tanto mais chato que o delgado, opposto, o que se vae afinando em ponta assaz tenue.

Estudemos tambem aqui a extructura exterior especifica da pellicula ovular. Veja-se fig. 92, representando um desenho do pôlo delgado de um ovo de Mansonia titillans. Nota-se que os elementos marginaes são particularmente chatos e extensos sobresahindo muito pouco além do nivel da peripheria do ovo propriamente dito. A propria ponta é occupada por alguns mammelãosinhos mais altos e mais cerrados uns contra os outros. Esta extructura lembra portanto de alguma maneira a descripta para o ovo de Culex confirmatus na pag. 18 da presente memoria, sendo de frizar que o achatamento dos elementos marginaes attinge dentro os ovos de Culicideos indigenas até agora por nós conhecidos, o seu extremo.

\section{Larva.}

Infructiferos novamente foram os nossos esforços para obter as larvas: não conseguimos fazel-as sahir dos ovos. Fica pois para o futuro o problema.

Não posso reprimir aqui a surpreza que me causa o aspecto dos ovos do tal Panoplites centrali-africano, qual os figura o prof. Theobald conforme uma photographia recebida do Dr. Daniels Vol. I, pag. 22, lit. a. Aquelles ovos têm um polo delgado afi-

(1) Vale a pena registrar aqui o facto que, entre diversas $Q$ e $\delta$ de Mansonia titillans submettidos ao tratamento de mel, houve um macho que morreu no dia 27 de novembro de 1903 , com 35 dias de duraçāo de vida no captiveiro. 
nado em filamento tão tenue e exquisito, que contrasta consideravelmente com o que observamos no ovo da nossa Mansonia titillans amazonica. Assim mesmo não ouso suppor logo uma confusão, tanto mais que tambem os outros ovos lá representados (Culex e Stegomyia) não têm o meu applauso incondicional; julgo, que a diversidade em questão esteja ainda dentro dos limites da possibilidade.

Muito extraordinaria a mais de um respeito é realmente a pupa de Mansonia conforme Theobald, descripta e figurada pelo prof. Theobald em 1903, Vol. IV, pag. 270, sobre material enviado da Africa Central (Uganda) pelo Dr. Low. Parece já com um cavalleiro medieval, mettido da cabeça aos pés dentro de uma armadura de aço luzente e de viseira descida. Espinhenta é a margem posterior das placas tergaes do abdomen, na linha mediana, e muito altas, qual bandeiras, se elevam as tubas respiratorias thoracicas, por sua vez de esdruxula configuração, terminando acuminadas e curvando-se para a frente. Os remos do polo anal são laminas ovaes providas, ao que parece, de chanfradura na ponta distal.

\section{0. - Ianthinosoma musica Say (1829)}

(Mosquito adulto, alado veja a nossa Estampa colorida IV, fig. 15 (femea); ovo e os seus pormenores. Est. K, figs. 93-97).

Este bello e relativamente grande mosquito distingue-se, além do seu colorido geral roxo, côr de iodo, que é aliás commum a ambas as especies do genero Ianthinosoma, aqui tratadas, deu origem ao nome, pelos pellos amarello-dourados, que se acham regularmente disseminados sobre todo o thorax. E' morador da mata bem como dos campos e dos capinzaes visinhos, tornando-se bem impertinente durante as horas calidas do dia em taes sitios, proximo ás vezes ás habitações humanas e mesmo entrando aqui e acolá. Nos mezes de novembro e dezembro de 1903 obtive muitos exemplares vivos de matas circumvisinhas da cidade. E' assaz dolorosa a sua picada, como aliás é tambem a das especies dos generos Taeniorhynchus e Panoplites.

Conhece-se a Ianthinosoma musica até hoje das seguintes localidades: Indiana (Estados Unidos da America do Norte) (1) - Trindade - Guyana Ingleza - Baixo Amazonas (Austen) e Pará (Durham. Goeldi) - Rio de Janeiro (Lutz, Mareira). (2).

Das 25 femeas vivas de Ianthinosoma musica que, durante a campanha de 1903 , entraram em gaiola, 5 vezes consegui obter ovos (20\%). Uma femea, apanhada repleta de sangue humano no dia 20 de Julho, nas matas de Murutucú, tomou outra vez sangue humano no dia 25 e foi encontrada pondo oros na manhan de 27 do mesmo mez, depois de um intervallo de 2 dias depois da segunda ração de sangue e de 7 depois da primeira (fig. 93). Eram cerca de 56 ovos, uma vez a postura completa. Poude acompanhar a funcção da postura com toda a folga, conseguindo tirar tanto photogra-

(1) Confer E. P. Felt, Mosquitoes of New-York State, 1904, pas, 276, * big wood mosquito*

(2) Outra especie Ianthinosoma posficata, typo do genero para Arribalzaga, seu autor, vae até a Republica 
phias, como fazer um desenho a lapis da parte anal, (fig. 97). Por este esboço se veem as peças componentes do apparelho ovopositor em plena protracção, deixando perceber os dous lobulos spatulitormes, por entre os quaes o ovo é expellido.

\section{Ovo.}

Dimensões: $0,75^{\mathrm{mm}}$ de comprimento (valor médio de 3 ovos medidos); $0,23^{\mathrm{mm}}$ de largura (valor médio de 3 ovos).

Bastante semelhantes á primeira impressão no seu aspecto e fórma ao ovo de Miansonia titillans, logo se verifica que o ovo de Ianthinosoma musica, além de ser menor, é mais arredondado e abobadado no seu contorno dorsal, - portanto menos anguloso, como claramente resulta pelas figuras 94 e 95 , das quaes a primeira (94) é uma microphotographia, a outra (95) um desenho feito com o auxilio da camara lucida, Tambem distingue-se o ovo de Ianth. musica pelos dous polos afinados, semelhantes aos de Mansonia.

As nossas figs. 95 e 96 inteiram quanto á extructura especifica da pellicula ovular. Examinada com augmento maior, apresenta-se a circumferencia quasi em toda a sua extensão occupada por espinhos de ponta não muito aguda, orientados obliquamente para a frente. O aspecto da superficie do ovo, visto com o tubo do microscopio levantado, é reproduzido pela nossa figura 96 , metade direita. Ha outra vez uma certa dissolução da regularidade na fórma, tamanho e orientação d'estes elementos marginaes no extremo do pôlo delgado e na peça de rolhamento no pôlo rombo (fig. 95, 94).

\section{Larva.}

Não consegui obter larvas dos ovos, nem alcancei das colheitas de larvas feitas na mata por arredores da cidade, larvas e pupas, que, experimentalmente provado, pudessem ser attribuidas á Ianthinosoma musica.

Pelo Vol. IV supplementar do prof. Theobald 1903, pag. $124 \mathrm{seg}$. vejo ainda durante a redacção d'estas linhas; que H. A. Morgan, publicou em 1902, uma nota relativa a historia da vida de Ianthinosoma musica, sobre observações feitas por um Dr. Duprée. (1) Uma femea pôz 40 ovos no dia 1 de maio. Chama o ovo semelhante ao da Stegomyia fasciata, porém maior. "Short spines pointing towards the so-called head of the egg are uniformly distributed over the entire shell. The egg has a flat and a convex surface and with the latter uppermost presents a distinctly fusiform shape ".

Diz-se que sahiram os primeiros mosquitos em 15 de maio, depois em 30 do mesmo mez e ainda em 10 de junho, levando o cyclo assim de 15 a 40 dias. Não encontro n'este extracto de nota a mais insignificante indicação acerca dos caracteres da larva e da pupa, de maneira que ainda uma vez e por este lado ficamos sem saber ao certo das phrases de Ianthinosoma musica, excepto o ovo.

(1) Observations up the mosquito Conchyliastes musicus. 14t th Proceeding Annual Meeting of Assoc. Econ. En. tomology Bull 37, New Series, Divis. Entomology, N. St. A. Department of Agriculture 1902. 


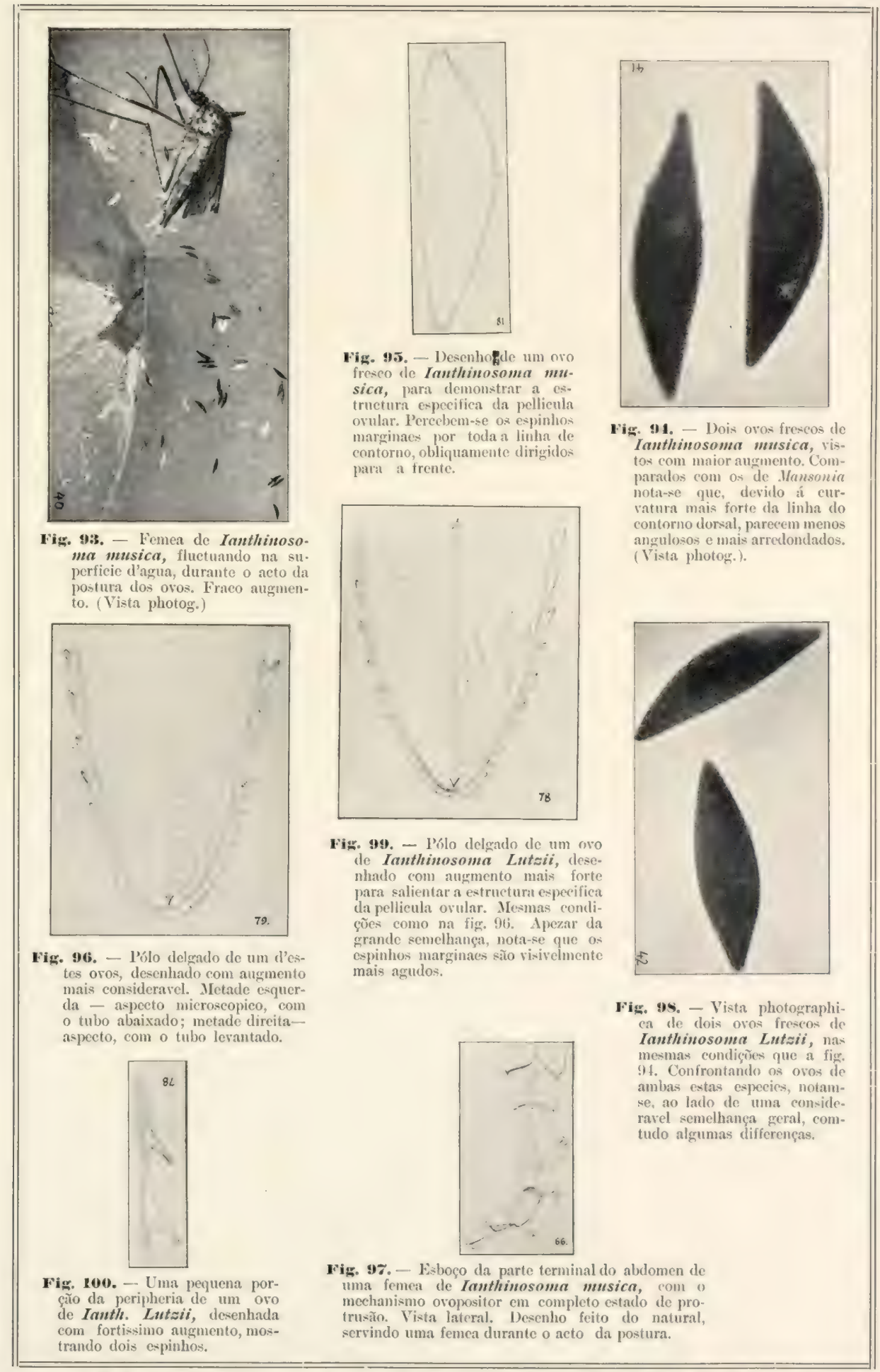

\section{Iantluinosonna 1711 sica-I. Lutzii.}





\section{1- - Ianthinosoma Lutzii Theobald (1901)}

( Mosquito adulto alado, veja nossa Estampa colorida IV, fig. 16 (femea). - Oros e os seus pormenores Est. K, fig. $98-100$.

Este bellissimo mosquito, facillimo de conhecer, quando ainda em bom estado e não aincla roçado e destituido de escamas, pelas duas vistosas fitas longitudinaes, na margem do thorax, formadas de pellos amarello-dourados, sómente em 1901 foi descripto pelo prof. Theobald, sobre material trazido pelos Drs. Austen e Durham do baixo Amazonas e do Pará. Desde então foi colleccionado por nós em innumeros exemplares n'estas mesmas regiões, (1) sendo positivamente um dos mosquitos mais frequentes aqui e além d'isto foram exemplares para o Museu Britannico apanhados na itha da Trindade, na Guyana Ingleza e em Surinam.

E' um mosquito indigena, que convém conhecer, já pela abundancia em que costuma apparecer em certos logares e em certas epocas. Manifesta prova d'isto é certamente a circumstancia de que, n'uma unica collecção de mosquitos organisada em dezembro de 1903 - janeiro de 1904 me vieram nada menos do que 247 individuos de Ianthinosoma Lutzii, de maneira, que chegava para prover todos os Museus.

E' identico em habitos o costumes á especie anterior.

\section{Ovo.}

A semelhança com J. musica estende-se como era de suppor, tambem ao ovo. (Figs. 98, 99, 100). O tamanho é o mesmo, é tambem o formato, como o demonstra o confronto entre as microphotographias (figs. 98 e 94). Realmente a unica differença leve, que eu fui capaz de descobrir depois de muita procura de distinctivos cathegori$\cos$, reside talvez na estructura exterior da pellicula ovular. Tornamos a encontrar os mesmos espinhos, virados obliquamente para a frente (fig. 99 ), como na especie anterior (fig. 96), todavia aqui se me afiguram como sendo por via de regra, de ponta sensivelmente mais aguda. Procurei representar o feitio d'estes elementos marginaes do ovo de Janth. Lutzii pelo desenho (fig. 100), feito ao microscopio com maior augmento. Nao obstante este pormenor, julgo que seria uma tarefa desesperadamente difficil de attribuir ovos com certeza a esta ou áquella d'estas duas especies de Ianthinosona, n'um caso onde oros de ambas fossem inteiramente misturados.

\section{Larva.}

Os meus esforços no intuito de obter larvas dos ovos postos em captiveiro foram frustrados da mesma maneira, como em tantos outros casos. Evidentemente tambem a larva de Janth. Lutzii se approximará da de Janth. musica em alto grau. Continúam por ora ignorados portanto os outros pormenores da historia do clesenvolvimento de J. Lutzii, exceptos os relativos ao ovo.

(1) Localidades amazonicas onde especimens d'este mosquito foram durante os ultimos annos colleccionados pelo pessoal do nosso Museu são: Obidos, - Paraná de Paranaquara, - I'rainha, - Arayollos, - Rio Xingú, - Teffé, - Rios Purús e Acre. 


\section{2. - Ioblotia (Trichoposopon) nivipes Theobald (1901)}

( Mosquito adulto, alado, vejà nossa Estampa colorida V, fig. 21 (femea), e figura 22 (cabeça de macho); larva, pupa e seus pormenores Est. L, figs. $101-105$ ).

E' um mosquito de tamanho avantajado. Embora á alguns respeitos semelhante ís duas especies de Janthinosoma supracitadas, ou a algumas especies de Sabethes e Megarhinus, Ioblotia nivipes distingue-se n'um exame mais cuidadoso, sem demasiada difficuldade, além do colorido da face superior, visivel na nossa Estampa, pela bella côr amarellacea crême, luzente do abdomen e os tarsos todo brancos do par médio de pernas.

E' um Culicideo silvestre. Os exemplares que serviram ao Snr. Theobald para a sua descripção original tinham vindo da llha dá Trindade, onde o Snr. Urich achou o logar de criação em poças d'agua em plantações de cacáo; desde então colleccionei e criei-o frequentemente aqui no Pará, Lutz encontrou-o no Rio de Janeiro e em São Paulo, conforme Theobald Vol. IV pag. 334. As imagines de Ioblotia, criadas por nós no captiveiro em 1903, nunca quizeram acceitar sangue. Sustentando-as com mel e agua, viveram em 4 casos annotados no meu diario de observações $5-4$ dias, 5 dias (duas vezes), 9 dias respectivamente, sendo este o maximo de duração de vida observado por mim aqui n'esta especie de Culicideos.

\section{Ovo.}

Nada sei até agora do ovo de Ioblotia nivipes por experiencia pessoal porque nunca cheguei a observal-o. Nem as femeas d'este mosquito apanhadas em liberdade chegaram a pôr no captiveiro, nem as femeas criadas de larvas trazidas da mata. No volume IV ( supplementar) pag. 33t o Snr. Theobald diz " The eggs are laid singly in smali numbers on the surface of the water; the rather large larva escapes the next day ".

\section{Larva.}

Durante os mezes de setembro e outubro de 1903 obtive muitas larvas de Ioblotia nivipes, que foram trazidas da mata de Murutucú em boccaes de vidro, nos quaes eu mandei entornar cuidadosamente a agua contida no coração ôco das Bromelias, no pé das folhas de bananeiras, em depressões de páos cahidos, etc., emfim em pequenas poças d'agua de chuva, formadas, conservadas espontaneamente lá fóra, sem intervenção humana alguma. Desenvolvem-se as larvas satisfactoriamente, conservando-se n'esta mesma agua; morrem porém substituindo-a por agua pura do encanamento. Evidentemente a larva de Ioblotia é uma d'essas que exigem uma agua rica em substancias humosas, detritos organicos de folhas em maceração, etc.

Como a imago, é grande naturalmente tambem a larva. Na fig. 101, as duas no centro são vistas de cima, as duas á esquerda são vistas pelo lado inferior.

A cabeça é arredondada, apparecendo n'ella como distinctivo assaz facil de reter a antenna, de tamanho médio, cylindrica, tendo na ponta distal uns cinco estyletes 


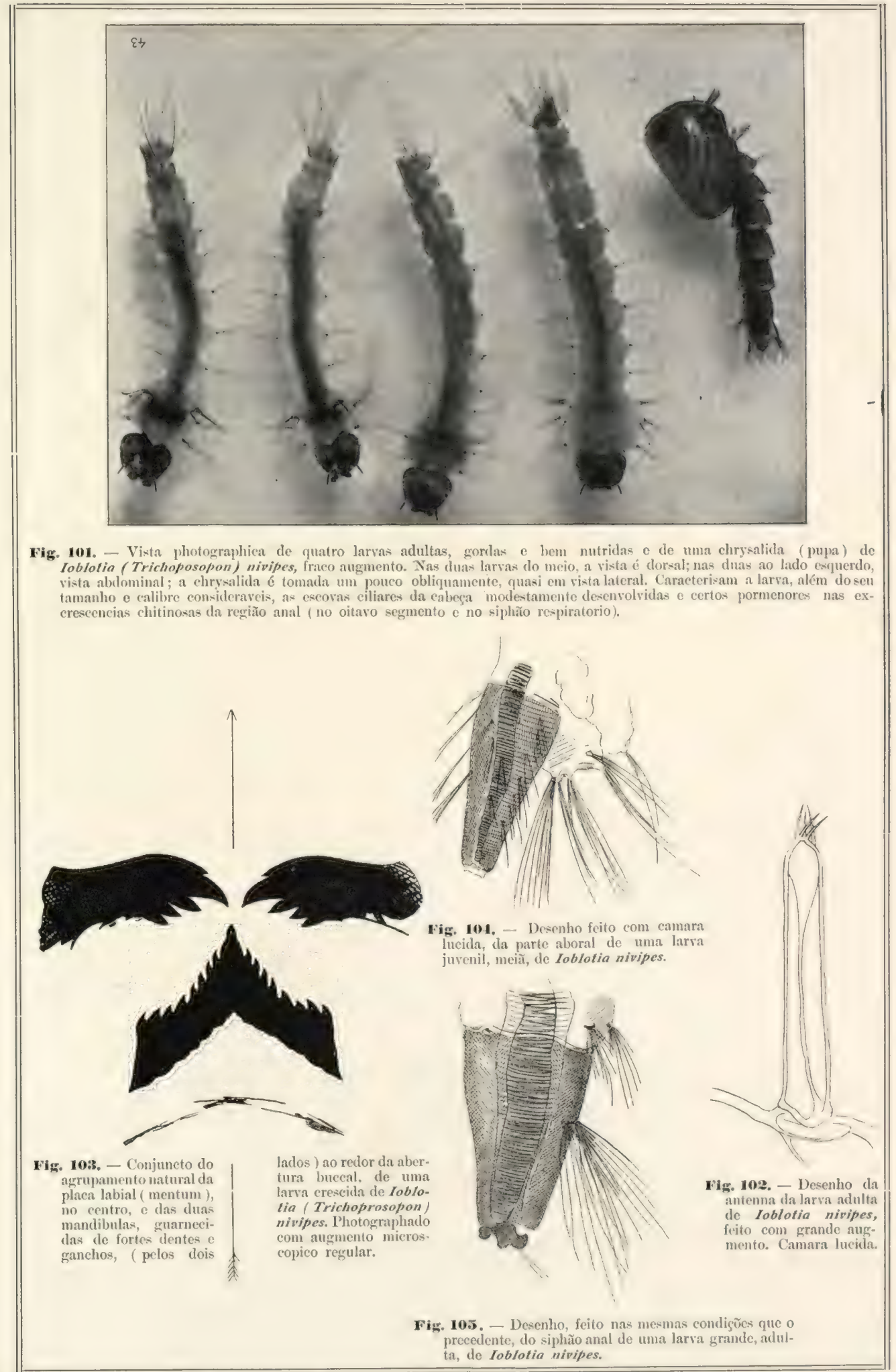

Ioblotia (Trichoprosopon) nivipes. 
chitinosos ( fig. 102). Ha outrosim como peça bastante caracteristica a placa labial, que em larvas adultas por via de regra mostra $7+1+7$ dentes aguçados na margem anterior: - é triangular e curta (fig. 103, em baixo). Parece que uma ligeira variação no numero dos dentes é cousa que cabe nos limites do possivel n'esta especie, pois de 3 larvas jovens, que tenho deante de mim, uma conta distinctamente $8+1+8$ dentes, bem como duas adultas mostram a formula $6+1+6$. Singularmente reforçada parece-me tambem a armação mediana da mandibula: 4 dentes fortes ao lado esquerdo do gancho grande e um possante dente ainda pelo lado direito (fig. 103). Ricos tufos de cilios largos e rijos nas margens do thorax. Quanto ao lado aboral da larva de Ioblotia nivipes temos os seguintes signaes notaveis: o siphão é curto, conico e de contornos formados de linhas quasi rectas (figs. $10 t$ e 105). Nas larvas jovens (fig. 10t) tem algumas fileiras longitudinaes de tenues cilios, reunidas em grupos de dous e trez; na larva adulta (fig. 105) o siphão é ornado com 2 tufos bem vigorosos, muito approximados, de cerdas possantes, rijas, insertas um pouco aquem da metade, pelo lado interior. Entre o siphão e a parte terminal do segmento anal acham-se uns tufos menores. Na margem posterior do segmento anal ostenta a larva nova (fig. 10t) uns 6 grupos de cerdas longas, das quaes o interior conta 8 , diminuindo o numero de cerdas de dentro para fóra, não possuindo o ultimo mais que 2. Na larva adulta nota-se uma reducção no numero das cerdas desses grupos (fig. 101) a duas e uma; attingem porém então um comprimento extraordinario, igualando bem os 3 ultimos segmentos abdominaes em extensão linear. Os folliolos branchiaes são de um lindo oval alongado, sem outros caracteres dignos de especial menção.

\section{Pupa.}

Massuda, corpulenta como é de esperar para um mosquito tão grande, a sua feição geral é visivel na nossa figura 101, á direita, que dá uma vista photographica lateral de uma chrysalida fresca e viva. As tubas respiratorias thoracicas são curtas e largas, um pouco como na Stegomyia. Na cabeça, região dos olhos, tem dous cabellos eriçados e isolados. A margem dos dous ultimos segmentos abdominaes é guarnecida de cada lado por um vigoroso tufo de cilios, contando eu de 24 a 26 em cada um dos ultimos e de 14 a 16 nos penultimos. Os segmentos anteriores tem um unico cilio no mesmo logar. São singularmente curtos e rechonchudos os remos anaes: n'uma pupa do sexo feminino, que serve-me de cotejo durante a redacção das presentes linhas, não s̃̃o muito mais compridas que o ultimo segmento anal, que por sua vez é bem 3 vezes mais largo do que longo.

No vol. IV, supplementar, pag. 334, o prof. Theobald deu em 1903 "notes on the life-history » de Ioblotia nivipes, acompanhadas de duas figuras (190 e 191 ) relativas á cabeça e á parte anal. Mas como o eminente especialista não dispoz, como elle confesSa, senão de uma unica larva « in an immature state» e ainda "the specimen somewhat shrunken», figuras e descripção sahiram imperfeitas, que com estes elementos só difficilmente se chegaria a reconhecer com segurança a larva viva d'esta especie. Sobretudo o siphão anal sahiu desastrado na fig. 191. 


\section{3. - Limatus Durhami Theobald (1901).}

(Mosquito adulto, alado; veja nossa estampa colorida V., fig. 20 (femea); larra e pupa e seus pormenores Est. M, figs. 106-113).

Ha apenas trez annos que o prof. Theobald, no appendice ao Vol. II da sua notavel "Monograph of Culicidae", pags. $349-351$ deu a primeira descripç̃̃o d'este muito notavel e bello mosquito, sobre material ido d'aqui, do Pará, colleccionado pelo dr. Durham. Desde então foi criado e colleccionado em amplas series, por mim no Pará, e parece, a julgar pelo que diz Theobald no recente Vol. supplementar (1903) paginas $333-334$, foi observado tambem recentemente no Rio de Janeiro. Até agora não constam outras localidades, senão sitas em territorio do Brazil, ficando como patria predilecta a região amazonica. (1)

Faltava até agora uma illustração do habitus de Limatus Durhami; julgamos prestar mais um serviço á sciencia, preenchendo esta lacuna por um desenho com inexcedivel cuidado feito sobre material fresco e vivo.

Caracterisam a imago de Limatus Durhami (fig. 20 da Est. V) os seguintes distinctivos: pernas proporcionalmente muito compridas, uma tromba igualmente bem comprida, e sobretudo a rica ornamentação polychroma do thorax, onde brilha uma figura em cruz em uma luzida côr de ouro, sobre fundo que ora puxa ao roxo e azulado, ora ao purpureo. $\mathrm{O}$ abdomen mostra um violeta ennegrecido, apparecendo uns salpicos brancos aos lados de cada articulação de segmento. As azas são um pouco sombreadas, como costumam ostentar principalmente muitos membros do genero Culex.

Quanto ao habitat e ao modo de vida, posso informar que o Limatus Durhami acompanha fielmente a Ioblotia nivipes em todos os pontos essenciaes. E' igualmente um carapanã sylvestre, diurno. Muitas vezes a mesma pocinha d'agua de Bromelia ou de Banana-sororóca continha ao mesmo tempo larvas de Ioblotia e de Limatus. Durante os mezes de agosto, outubro, novembro e dezembro de 1903 criei centenas de larvas d'este mosquito, obtendo as imagines. Estas imagines criadas no captiveiro todavia não acceitaram sangue e tambem nunca puzeram ovos. Sustentando-as com mel e agua viveram na média de 2 a 8 dias; comtudo notei que uma imago durou 16 dias, outra 17 , outra 19, outra 22 e uma mesmo 32 dias, a maior duração de vida observada em individuos captivos d'esta especie de Culicideo.

\section{Ovo.}

Como acabo de declarar, não tive a ventura de encontrar os ovos. De pocinhas de agua sylvestre não os obtive, e as femeas criadas no captiveiro não quizeram picar e chupar sangue, nem pôr oros. A alimentação com mel de abelha não produziu postura alguma.

(1) Temos exempiares colligidos no Oyapoc pelo pessoal do nosso Museu. 


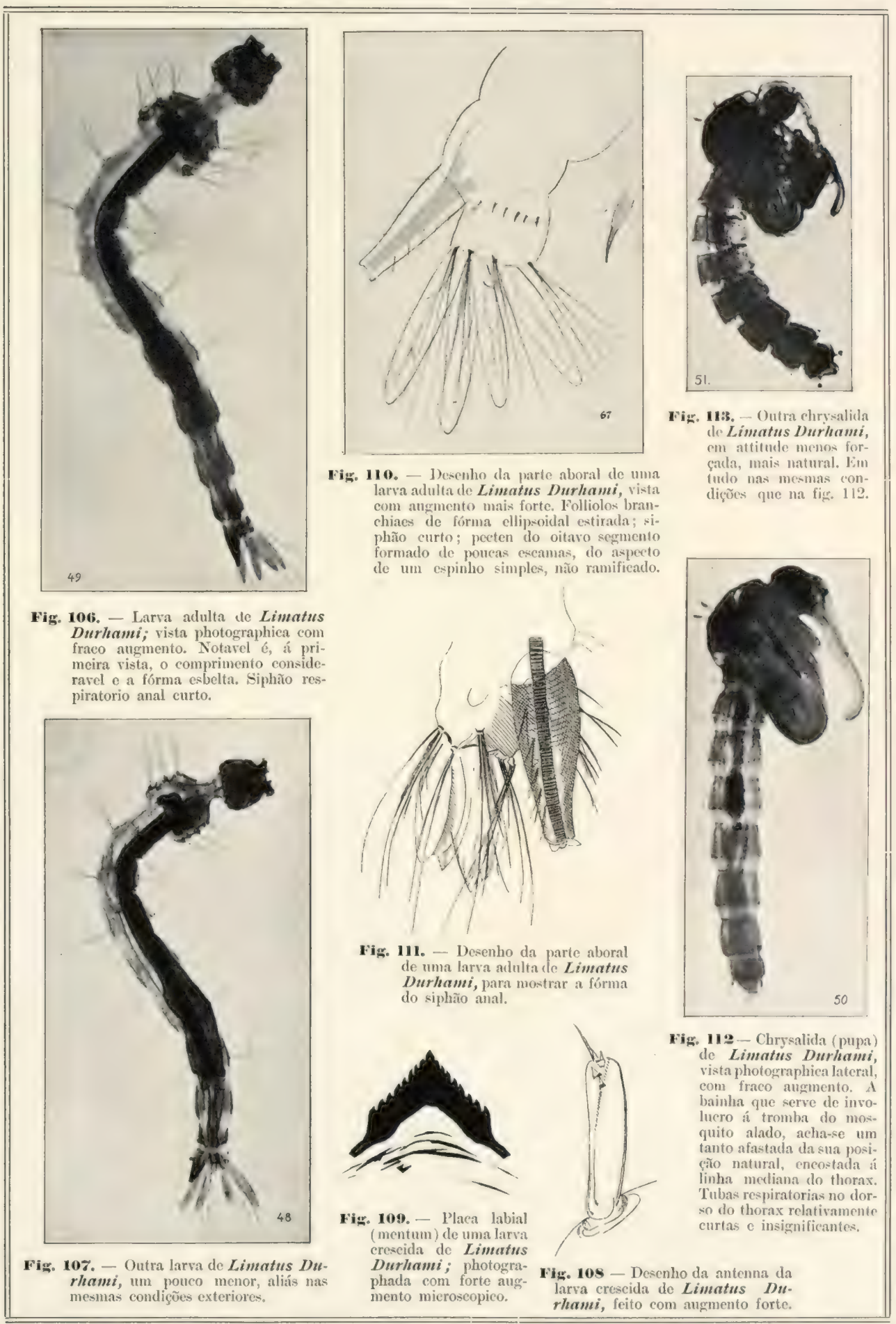

Limatus Durlnami. 



\section{Larva.}

Innumeras larvas, desde meio maduras até adultas, foram-me trazidas em agua, da mata. Sempre cresceram facilmente, não exigindo cuidado especial algum. Deixando-as desenvolver na mesma agua original, rica em detritos de folhas, flôres, etc., vingam quasi todas.

O aspecto geral da larva de Limatus fornecem as nossas microphotographias f'gs. 106 e 107. E' comprida e esbelta, em comparação com a larva de Ioblotia nivipes. A fórma da cabeça é mais rectangular, bem curva sómente na margem frontal. Muito exquisita configuração têm as antennas (fig. 108), que são reduzidas a um cylindro tão curto que é preciso procural-as, tão facilmente escapam á vista. Com forte ampliação, sómente, apparecem na parte terminal uns dentesinhos curtos, curvos e largos, os quaes evidentemente substituem os costumados estyletes que, nas larvas dos outros mosquitos, lá se costumam encontrar. A placa labial da larva de Limatus Durhami (fig. 109) é uma peça em fórma de pá de arado, estreita, com $8+1+8$ dentes na margem anterior, tanto quanto posso vêr das minhas respectivas preparações microscopicas.

A guarnição de cerdas marginaes thoracicas é farta, porém relativamente tenue, (figs. 106 e 107). Cilios menores, reunidos em 2, 3 e 4, assentam sobre as margens dos segmentos abdominaes, que apparecem singularmente estirados. Relativamente á região anal as seguintes informações: o siphão é curto, conico, porém os contornos externos formados de linhas curvas em fórma de coxa ou de S. (fig. 111). Em comparação com o da larva de Ioblotia nivipes (fig. 104), é de base mais estreita. Possue sobre os lados externo e interno umas fileiras longitudinaes de cilios que são reunidas em grupos de dois nas series internas, isolados ou aos pares nás externas (fig. 111). Assim ganha o siphão respiratorio da larva adulta de Limatus Durhami um aspecto que se assemelha áquelle que encontramos no siphão da larva juvenil de Ioblotia nivipes (fig. 104). Cerdas compridas e rijas cercam, como no caso de Ioblotia, a margem posterior do segmento anal. O pecten é formado de escamas em fórma de um unico espeto curvo (fig. 110). São poucas, uma meia duzia talvez. Os folliolos branchiaes são regularmente oblongos, compridos, (figs. 106, 107, 110 e 111 ) sem outros signaes especiaes.

\section{Pupa.}

O habitus geral é demonstrado pelas figuras 112 e 113 , ambas vistas lateraes. E' comprida e franzina em comparação com a chrysalida de Ioblotia. Os tubos respiratorios thoracicos são tenues, tubulares e compridos. Os dous ultimos segmentos abdominaes têm, como n'aquella tufos vigorosos de cerdas na margem exterior. Curtos e de pouco desenvolvimento superficial são novamente os remos anaes.

Não posso reprimir um sentimento, de que ha entre larva e pupa de Limatus Durhami não poucos traços de parentesco com larva e pupa de Ioblotia, relativamente mais do que com quaesquer outros generos e especies. Aliás também já o prof. Theobald em 1901 e 1903 tinha collocado Limatus e Ioblotia em proxima visinhança no systema dos Culicideos. 


\section{4. - Megarhinus separatus Arribalzaga (1891)}

(Mosquito adulto, alado, veja nossa Estampa colorida V, fig. 19 (macho o7). Ovos, larva, pupa e os seus pormenores Est. N, figs. 114-129).

A este gigantesco e sobremodo bello mosquito já tive occasião de referir-me no meu primeiro trabalho (pags. 7 e 8 desta reimpressão).

Foi colleccionado até agora em Cayenna, Guyana Franceza - Manáos - Pará (Walker, Goeldi) - Baixo Amazonas (Austen) - Rio de Janeiro (Lutz) - Republica Argentina (Gran Chaco).

Não é raro na região amazonica. No correr dos ultimos annos não sómente me trouxe numerosos exemplares de diversas localidades o nosso preparador de entomologia, o Sr. Adolpho Ducke, como obtive ovos e larvas de uma chacara visinha do proprio Museu. Affirma o Sr. Ducke que a picada d'este mosquito, que elle teve occasião de experimentar, é bem dolorosa, comparando-a á ferroada de uma cába (Vespidea). Larvas vivas e uma chrysalida obtive tambem com agua do ôco de um páo clas matas de Murutucú (Pará) em 29 de agosto de 1903. Morrendo a pupa, formou-se outra no dia 4 de setembro, que já no dia 5 forneceu uma imago. Esta, sustentada com mel e agua, viveu até o dia 14, - portanto 9 dias - sem acceitar sangue (o que se experimentou por diversas vezes).

De outras 6 pupas que obtive no mesmo dia 29 de agosto, saíram, já no dia 30 . trez imagines, do sexo masculino. No dia 2 de setembro metamorphoseou-se mais uma larva em pupa. No dia 9 saíram mais duas imagines, - justamente por occasião de uma visita do Exm. Sr. Governador do Estado, Dr. Augusto Mlontenegro ao Mluseu acompanhado dos illustres personagens mencionados nos pareceres do frontespicio. Suas Exs. tiveram occasião de ouvir o zumbido d'estes dous gigantescos carapanãs e ficaram impressionados pelo sonoro contrabaixo d'esta roz.

\section{Ovo.}

Um acaso poz-me de posse dos oros e das larvas de Megarhinus separatus, que tinham sido depositados n'um caldeirão abandonado, com agua de chuva, n'uma rocinha não longe do Museu. Os oros, (fig. 114), 19 ao todo, fluctuavam horizontalmente sobre o espelho d'agua, reunidos em 4 grupos, de 4, 5, 6 e 4 oros juxtapostos, lembrando o agrupamento dos fios em fórma de cartucheira tira-collo, como os conhecemos nas especies Taeniorhynchus fasciolatus e T. Arribalzagae. Talvez tivessem formado a principio um só grupo ou fio, o que augmentaria a semelhança. Os ovos já tinham deixado sahir as larvas; mostravam uma dehiscencia longitudinal interessando um terço mais ou menos do polo não verrucoso (fig. 115). Os maiores que eu tenho encontrado até agora na familia dos Culicideos, são perfeitamente visiveis a olho nú, pois medem nada menos do que $1,02 \mathrm{~mm}$ na média, portanto o dobro de um oro de Stegomyia, por exemplo. Nuito exquisito e descommunnal o seu aspecto e configuração. São comparareis a uma clava, da qual um pouco mais da metade mostra a superficie toda occupada por uns tuberculos que á primeira vista parecem arredondados. Submetti esta estructura especial da pellicula ozular, na fórma do costume, a um exame mais detido. Com aug- 
N

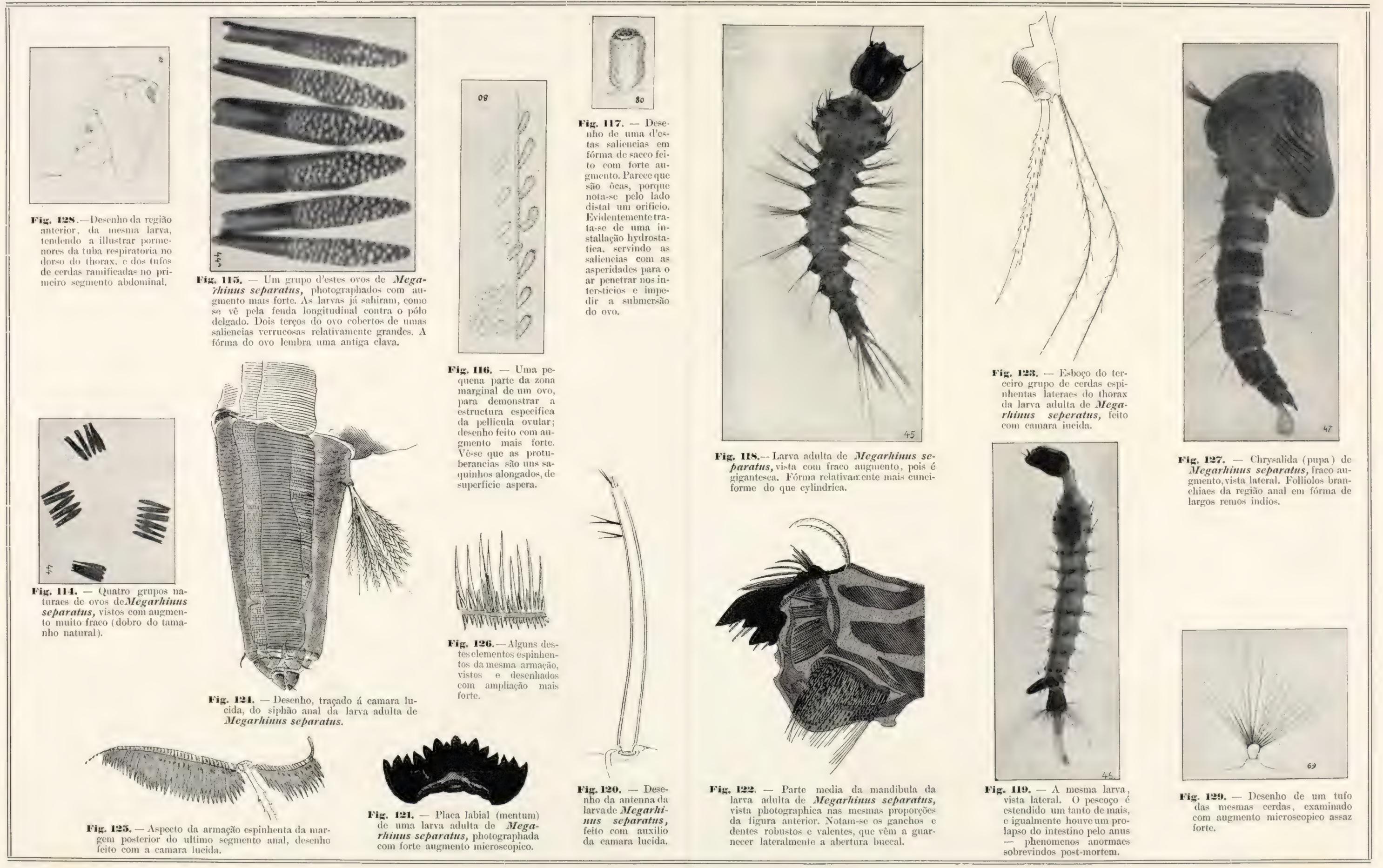

Megarhinus separatus. 

mento maior vê-se, como ensina o nosso esboço (fig. 116), que da superficie uniformemente granulosa sáem em distancias regulares e equidistantes uns prolongamentos em feitio de sacco. Emprego esta comparação, porque maior ampliação ainda fez-me vêr que elles têm um orificio na parte exterior (fig. 117), o que me faz desconfiar que são ôcos. Ora, sendo ainda toda a superficie semeada de asperesas, comprehende-se, como por todos estes meios e recursos é obtido um sem numero de cantos, dobras, sinuosidades e cavernas, onde o ar póde achar um ponto de apoio e esconderijo, alcançandose um perfeito apparelho hydrostatico, nimiamente idoneo para garantir a fluctuação segura do ovo no espelho d'agua. A tendencia de formar excrescencias com o fim de auxiliar a funcção hydrostatica attinge aqui nos ovos de Megarhinus separatus evidentemente um dos seus extremos, - tanto quanto me consta, sobrepujado sómente ainda no caso do ovo dos Anopheles.

\section{Larva.}

A colossal larva (fig. 118 vista dorsal, fig. 119 vista lateral) mede nada menos do que $17-18^{\mathrm{mm}}$. Ella possúe um habitus caracteristico, pois em vez de ser mais ou menos cylindrica como $\mathrm{em}$ todos os outros casos, assume a fórma de um cône estirado; o mais largo é a região do thorax, e os segmentos abdominaes vão successivamente diminuindo em largura da frente para traz, de maneira que o segmento IX, anal, apenas tem a metade do segmento I. Também não quero esquecer de communicar que até o. colorido é notavel na larva de Megarhinus separatus, pois é de um bonito tom rosa ou carmim pallido, que dá bem na vista.

$\mathrm{Na}$ possante cabeça merécem ser notadas as antennas longas, cylindricas, suavemente curvas (fig. 120). Vejo em sua extremidade dous estyletes conicos e duas cerdas finas; um par de duplas cerdas observo também insertas no primeiro sexto, pelo lado interior. A não ser o tamanho diverso, a antenna larval de Megarhinus separatus assemelha-se em certos respeitos á de Ioblotia nivipes (fig. 102).

Muito extraordinaria é a placa labial da larva de Megarhinus (fig. 121). Parece uma corôa. A formula dos dentes do exemplar adulto que tenho diante de mim, é $8+1+8$. Agora, o que empresta um cunho singular a este mentum é a circumstancia de serem os dentes, sobretudo os grandes medianos, assáz obtusos. Cousa que também não se vê nas placas de outras larvas culicideas, é a circumstancia de serem alternativamente compridos e curtos os dentes. Numerando os dentes de um lado I, 1, 2, $3,4,5,6,7,8,-02 .^{\circ}$ e $70^{\circ}$ são os maiores, seguindo-se-lhes os $30^{\circ}, 6.0^{\circ}$ e $8 .{ }^{\circ}$ com comprimento médio, ostentando emfim os restantes $1.0^{\circ}, 40^{\circ}$ e $5 .^{\circ}$ menor importancia. Ora, na relativa obtusidade dos dentes, como na diversidade alternativa do tamanho a placa labial de Megarhinus adquire uma singular semelhança com a da larva adulta de Chironomus, culicideo não haematophago, como ensina um confronto com a figura 38 , pag. 125 do precioso livrinho de Miall op. cit.

Respeitavel arma de ataque para segurar e soltar particulas alimenticias é outrosim a mandibula (fig. 122) com os seus formidareis dentes, dos quaes vejo existirem 4 sómente.

O que no thorax (fig. 118) chama principalmente a attenção são os espinhos grossos, robustos, levemente curvos, por sua vez espinhosos a modo de galho de pi- 
nheiro, implantados nos mesmos mamillões de cada segmento, onde se inserem também com a sua base vistosos pellos tenuemente plumosos (fig. 123). Taes espinhos repetem-se aliás também, pelo menos um a um, nas margens dos segmentos abłominaes. O siphão ¿respiratorio bem visivel só na vista lateral, fig. 119, é recuado para a frente. E' de fórma conica estirada (fig. 124) de contornos rectilineos, não muito grande; dous tufos de pellos plumosos acham-se insertos na parte basal, interior. A beira posterior do segmento anal é occupada por uma fileira continua de escamas spiniformes e diversos tufos valentes de muito compridas cerdas, como se vê pelas figuras 125 e 126 . Digno de nota é que os acostumados folliolos branchiaes parecem faltar, sendo substituidos por umas protuberancias hemisphericas na sua ponta livre, pouco proeminentes (formação anormal, post-mortem, devida á turgescencia na formalina, é o prolapso do intestino pelo anus, como se vê na pag. 119).

\section{Pupa.}

A ella se referem as nossas figuras $127-129$. E' por sua vez gigantesca, medindo, mesmo curva como $\hat{e}$, ainda $15^{\mathrm{mm}}$ pelo menos de comprimento. Tornam a apparecer dous cabellos tenues na região dos olhos, como os encontramos na pupa de Ioblotia, com a qual offerece, a mais de um respeito, pontos de contacto. As tubas respiratorias thoracicas (figs. 127, 128) são compridas e tubulares. No meu exemplar, que é do sexo feminino, os remos anaes são largos, obtusamente acuminados, de contornos menos circulares, apparentemente assymetricos.

Vistoso é o par de tufos de cerdas, implantado no dorso do primeiro segmento abdominal (figs. 127, 128, 129). Aliás esta "soie natatoire" como tinha sido chamada por Meinert em 1886 em sua descripção da chrysalida do Culex annulatus, é cousa que se vê regularmente nas pupas de todos os Culicides de mim conhecidos. Na pupa de Megarhinus separatus, comtudo, adquire um desenvolvimento descommunal de talvez não menos de 50 pellos plumosos.

O Sr. Theobald já tinha dado, em 1904, no appendice ao volume II da sua obra, na pag. 351, uma curta nota assaz boa sobre larva e pupa de um Megarhinus, remettido de Granada por um Dr. N. S. Durrant, nota não acompanhada de figuras. Larvas tinham tambem sido enviadas pelo Dr. Bancroft, de Queensland, attribuidas ao Megarhinus speciosus. No recente volume IV (suppl.) de 1903, o Sr. Theobald refere que larvas de Meg. separatus tinham sido observadas e criadas, n'um barril d'agua, em Manáos, mas nåo diz por quem. Accresce "The pupal stage lasts eight days. They are called "carapañ " and bite very badly in the day-time and at night."

O que porém nos deve merecer particular attenção é a descripção detalhada, acompanhada de duas estampas, da larva e pupa de Toxorhynchites speciosus Skuse, (1) natural de Queensland, sobre material fresco colligido e remettido ao British Museum

(1) Toxorhynchites é um novo genero, proximo parente de Megarhinus, formado em 1901 pelo Sr. Theobald. para outras especies com palpos curtos na imago do sexo feminino. 
em Londres pelo Dr. Bancroft (pags. 118-121). As figuras da larva (67 a) e da pupa (67 b) correspondem tão bem com as nossas figs. 89 e 91 , relativas ao Meg. separatus amazonico, que o proximo parentesco é, ao primeiro golpe de vista, sensivel. Sobretudo as larvas correspondem a um ponto tal, que se poderiam confundir. Nas figuras relativas aos pormenores (pag. 120) achei unicamente uma divergencia um tanto maior quanto aos espinhos espinhosos do thorax, que o $\mathrm{Sr}$. Theobald qualifica de *thick serrated spines", desenhando-os, como bilateralmente achatados (fig. 68, c.). Não são assim nả nossa larva: os espinhos secundarios são insertos todos ao redor do eixo.

O que me surprehendeu um tanto, foi a noticia acerca do ovo de Toxorhynchites immisericors Walker, que o Sr. E. E. Green em Ceylå observou na agua de um tôco decepado de bambú: "The eggs are laid singly. They are of a regular ovoid shape and float on their sides on the water, rupturing accross the aequator into two equal halves to liberate the young larvae». No nosso Megarhinus separatus amazonico vimos que os ovos são 1) postos em fileira, uniserial, semelhante aos fios de certos Taeniorhynchus 2) que a dehiscencia é longitudinal.

Nos seus caracteres larvaes e pupaes, ponderados no seu conjuncto, o Megarhinus assume inquestionavelmente uma posição bastante isolada em relação aos outros Culicideos haematophagos aqui tratados. Ha factores que me parecem apontar por um lado para os Anophelinae, por outro para os generos não haematophagos Chironomus Corethra, Mochlonyx e Tanypus. Com todos estes coincide em relação á fórma triangular, conica, da larva, sendo a semelhança maior com a larva de Mlochlonyx e Anopheles, sobretudo quanto á configuração da parte anal. Com Chironomus, já tive ensejo, de frizar o aspecto e conformação parecidos da placa labial (Miall loc. cit. fig. $38 \mathrm{c}$; Felt loc. cit. pl. 49, fig. 5 e Meinert loc. cit., Est. II, fig. 79).

\section{5. - Sabethes longipes Fabricius (1805)}

(Mosquito adulto, alado; veja a nossa Estampa colorida V, fig. 18, femea; 18 a, femea voando, vista de lado).

Os bellos mosquitos que fazem parte do genero Sabethes, e aos quaes já alludi no meu primeiro trabalho (pag. 9 d'esta reimpressão), possuem o seu distinctivo o mais saliente, perceptivel a olho nú mesmo e a grande distancia, nos seus remos, que, formados de escamas normalmente alongadas, ornam maior ou menor extensão aboral da parte tibial das pernas, sobretudo do par mediano. São dos mais vistosos da familia, formando com os Megarhinus e Limatus a aristocracia. Interessante é, agora, que todos elles são do Brazil, e sobretudo amazonicos.

O conhecimento das especies d'este genero era uma embrulhada medonha até bem pouco tempo, devido á escassez de material nos museus europeus e á confusão produzida pela incerteza, sobre a diversidade do aspecto dos dous sexos. O Museu do Pará contribuiu para crear luz n'esta escuridão. Mediante farto material fresco remetti- 
do d'aqui, (1) o Prof. Theobald chegou a rever a synopse, estabelecida originalmente em 1901 sobre pauperrimo e pessimo material antigo, reformando por completo o respectivo capitulo no Vol. IV (supplementar) 1903, pags. 321 - 330. Removendo para um genero novo, Sabcthoides, especie confusus Theobald uma especie sem remos em ambos os sexos (quando antes tinha sido ora tomada por $q$ de Sabethes remipes ou de Sabethes nitidus), ficam conforme o actual estado de saber permanecendo quatro especies no genero Sabethes, assim descriminadas pelo Sr. Theobald:

Pernas medianas sómente com remos.
| Remos todo pretos
S. remipes Wiedemann.
I Remos brancos no apex .......
S. nitidus Theob.

Todas as pernas mais ou menos com remos, com escamas brancas nos remos como com escamas pretas

Sem branco nas pernas.

S. longipes Fabricius.

S. Lutzii. Theob. nov, espec.

Jí se vê que o nosso especimen figurado Est. V, fig. 18, paraense, fresco e vivo, não podia ser attribuido a outra especie senão a S. longipes Fabr. - Os mosquitos do genero Sabethes são frequentes no mato, até no proprio Bosque Municipal, no Utinga, no Murutucú. Perseguem a gente desde a entrada na mata até a sahida, mas não é commum verificar-se ao certo que um realmente picasse.

O especimen que serviu de modelo para a nossa Estampa colorida, entrou com bonito tempo de sol no dia 20 de outubro de 1903, ao meio dia, do jardim, pela janella da residencia directorial, quando nós almoçavamos. Foi apanhado n'um tubo largo de vidro. Embora morresse horas depois. deu perfeitamente tempo para apreciar o seu exquisito porte no vôo e de fixal-o por um desenho, cuja absoluta fidelidade garantimos. Emquanto que as pernas da frente estão levantadas em fórma de S., é arreado o par médio, provido dos remos largos, e levantado outra vez em audaciosa volta por cima do abdomen, alcançando a projecção das pontas quasi a margem posterior do thorax, é sustentado o terceiro e ultimo par de pernas. Este vôo tem summa elegancia, tanto mais que o magnifico mosquito, como se quizesse ser admirado, paira fixo no ar, aqui e acolá por dilatados momentos, vibrando sómente as azas.

Que femeas de Sabethes aceitam sangue verificamos com certeza com diversos individuos, assim como com um apanhado perto do forno do lixo, no dia 25 de novembro de 1903. Picou a mão offerecida na tarde do mesmo dia. Infelizmente conseguiu fugir, sem ter procedido á postura, no dia 1 de dezembro, depois de 5 dias passados no captiveiro. De sete outros individuos viveram, com mel e agua, nao querendo acceitar sangue (senão com excepção de uma) no captiveiro, respectivamente: 5 dias, 2 dias, 2 dias, 1 dia, morrendo sempre sem pôr ovos. Nem da femea do dia 25 de novembro de 1903 , que finalmente ainda se escapou, nem da de 17 de dezembro, que tomou sangue humano no mesmo dia, consegui postura, morrendo esta ultima, já no dia $29,-2$ dias depois.

(1) Proveniente do rio Trombetas, -- de Obidos, - de Alemquer, - de Itaituba (Tapajós), - Faro, Ieffé, - rio Iapurú, - Tabatinga, - Oyapoc, e colleccionado pelo pessoal do nosso Museu. 


\section{Ovo e larva.}

Acabo de referir que baldados foram os meus esforços de esclarecer a historia natural d'esta especie. De todos os generos tratados no presente trabalho permanece unicamente o genero Sabethes, refractario ao descobrimento do cyclo evolutivo e envolto ainda em completa escuridão. Entretanto será só questão de tempo e de paciencia; dia virá, em que também cahirá o panno que nos véda o completo conhecimento da biologia d'estes mosquitos, que já por sua exquisita configuração e extranha belleza do seu colorido tentam e provocam para taes estudos.

\section{6. - Cellia (Anopheles) argyrotarsis Desvoidy (1828)}

(Mosquito adulto, alado veja nossa Estampa colorida II, fig. 10 (femea); fig. $10 a$ tarso do ultimo par de pernas da especie typica "albitarsis»; fig. $10 b$ idem da variedacle "albipes»; ovos, larva e os seus pormenores; vide Est. O., figs. 130 - 137).

Este nosso principal representante brazilico e sul-americano em geral da tribu dos Anophelinae, famigerada como transmissora da malaria, é conhecido pelo povo do interior do valle amazonico pela designação trivial indigena de "moroçóca». O nosso povo paraense não o confunde com outros mosquitos, (1) distinguindo regularmente entre «carapanãs » e "moroçocas ". (2) Confira-se o que escrevi no meu primeiro trabalho, pag. 10 e seguintes da presente reimpressão, acerca das generalidades.

Creio que o proprio $\mathrm{Sr}$. Theobald, tendo de decidir qual das illustraçð̃es a melhor, a d'elle Pl. I, figs. 1 e 2, feita em pequena escala e com material morto, ou a nossa fig. 10. Est. II, executada com abundante material fresco e vivo e na escala grande de $10: 1$ n'este como nos outros casos sem hesitar votava pela nossa, o que é aliés natural pela maior somma de especial attenção dirigida na representação absolutamente fiel e exacta dos nossos principaes Culicideos paraenses e brazileiros.

Quanto ao cyclo de desenvolvimento de Cellia (Anopheles) argyrotarsis, por dilatado tempo não tinha conseguido penetrar no seu conhecimento. Quiz o accaso que eu nunca obtivesse as larvas, em estado livre, dos arredores da cidade, ao passo que soube pelo cuidadoso Relatorio da Commissão Ingleza (Drs. Myers e Durham) que os seus membros tinham achado abundantes larvas d'este Anopheles nos arredores da cidade, sobretudo em poços, perto de Santa Izabel, onde anteriormente se tinha retirado barro para as ollarias circumvisinhas.

Cellia argyrotarsis é entretanto hospede não muito raro na peripheria da cidade. Em nossa casa, no Nuseu, já apanhamos bem umas 3 duzias de exemplares, talvez, du-

(1) O que jai náo acontece pelo littoral do Sul do Brazil. Na Bahia por exemplo lembro-me perteitamente, que o termo de muriçóca "é applicado indifferentemente a qualquer mosquito que pica, diurno ou nocturno. Entretanto, no Ceará e Rio Grande do Norte sei que applicam os nomes triviaes de esovella e "pereréca especialmente para 0 Anopheles.

(2) Refere o Sr. A. Decke, entomologista do nosso Museu que, no baixo Amazonas, regiảo de Alemquer, ato tribuem a fumaça do esterco de gado queimado o effeito de enxotar os outros mosquitos. sendo porém esta praxe sem ef. feito contra o Anopheles. 
rante estes ultimos annos. (1) E' sempre de noite, principalmente a anoitecer, que estes individuos rêm entrando pela janella, de mistura com exemplares de Taeniorhynchus fasciolatus e Mansonia titillans, comportando-se em geral do mesmo modo. Frequente comtudo não se póde chamar este Anopheles pelos lados do Museu, felizmente.

Já estava desesperando de: conseguir observações originaes sobre o cyclo de desenvolvimento de Cellia argyrotarsis, quando, ainda durante a redacção do presente trabalho, a persistente applicação do meu methodo de criação poz-me, nos ultimos dias, de posse dos dados desejados.

\section{Ovo.}

Uma femea de Cellia argyrotarsis var. albipes foi apanhada, em minha residencia, durante o jantar, ao cahir da noite, picando pessoa da minha familia, na noite do dia 1 de fevereiro de 1905. Repleta de sangue, foi posta em gaiola, com agua e uma tamara pendurada. Tomou outra ração de sangue humano na tarde do dia 4 de fevereiro, no dia 6 outra de sangue de cobaya e ainda outra, do mesmo sangue, no dia 8 de fevereiro. Na manhan do dia 13, pelas oito para 9 horas encontrei-a pousada sobre a agua, pondo; já existiam 8 ovos então. Durante a manhan o numero dos oros augmentou ainda até 33. Pelas duas horas da tarde a femea morreu, sem causa exterior perceptivel. O agrupamento dos oros era o que se vê na fig. 130, Est. O, fielmente apanhado nas primeiras horas pelo apparelho micro-photographico, com augmento fraquissimo. Ha uma lembrança do arranjo estrellar, como o observou e desenhou Grassi para o Anopheles maculipennis na Italia (Tav. IV fig. 3 ). Sómente uma meia duzia de oros fluctuara fóra, isoladamente.

Dimensões: $0,424^{\mathrm{mm}}$ de comprimento (valor médio de 3 oros medidos) e $0,185^{\mathrm{mm}}$ de largura (valor médio de 3 oros). (2)

São muito exquisitos no seu aspecto os ovos de Cellia argyrotarsis, como se póde ver pelas nossas figuras photographicas Est. O, figs. 131, 132 e 133. Representa a figura 131 quatro ovos vistos pelo lado inferior, com fraco augmento microscopico. E' preciso distinguir duas partes no ovo de Anopheles: 1) o corpo propriamente dito, 2 ) os appendices lateraes, em fórma de aza. O primeiro apresenta-se todo escuro, como corpo opaco; os segundos, serrilhados no sentido transversal, transparentes, destacamse como campo claro. Ganhei a convicção de que estas azas são compostas de tubos compridos, juxtapostos e rasios, isto $\varepsilon$, cheios de ar, e que para preencherem a sua funcção hydrostatica apresentam aqui um desenvolvimento extremo, todo sui generis, de uma tendencia cujos vestigios, ora mais ora menos accentuada, encontramos a cada passo n'esta memoria no estudo da estructura especifica da pellicula ovular. Estas azas acompanham o ovo pelos dois lados, como estofo grosso, e servindo como as abas de fluc-

(1) Surpreende-me o facto de que, durante a presente estação churosa de $190+-1905$, este Anopheles repentinamente apparece no quarteirào do Museu e adjacencias com mais frequencia, sendo notado especimers quasi todos os dias. Até de dia claro já se otservou um, picando na officina taxidermica.

(2) I’ara o ovo de Anopheles maculipennis Xuttall e Shipley dão $0,7-1.0^{\mathrm{mm}}$ no comprimento, e $0,16^{\mathrm{mm}}$ de maior largura. Howard entretanto só dá $057^{\mathrm{mm}}$ de comprimento. - Infelizmente Christopliers e Stephens nào dão no seu trabalho as medidas relativas ás suas especies de Anophelides da India. Embora variaveis dentro de certos limites as di. mensões do ovo, todavia nào as considero cousa superflua de mençào. 


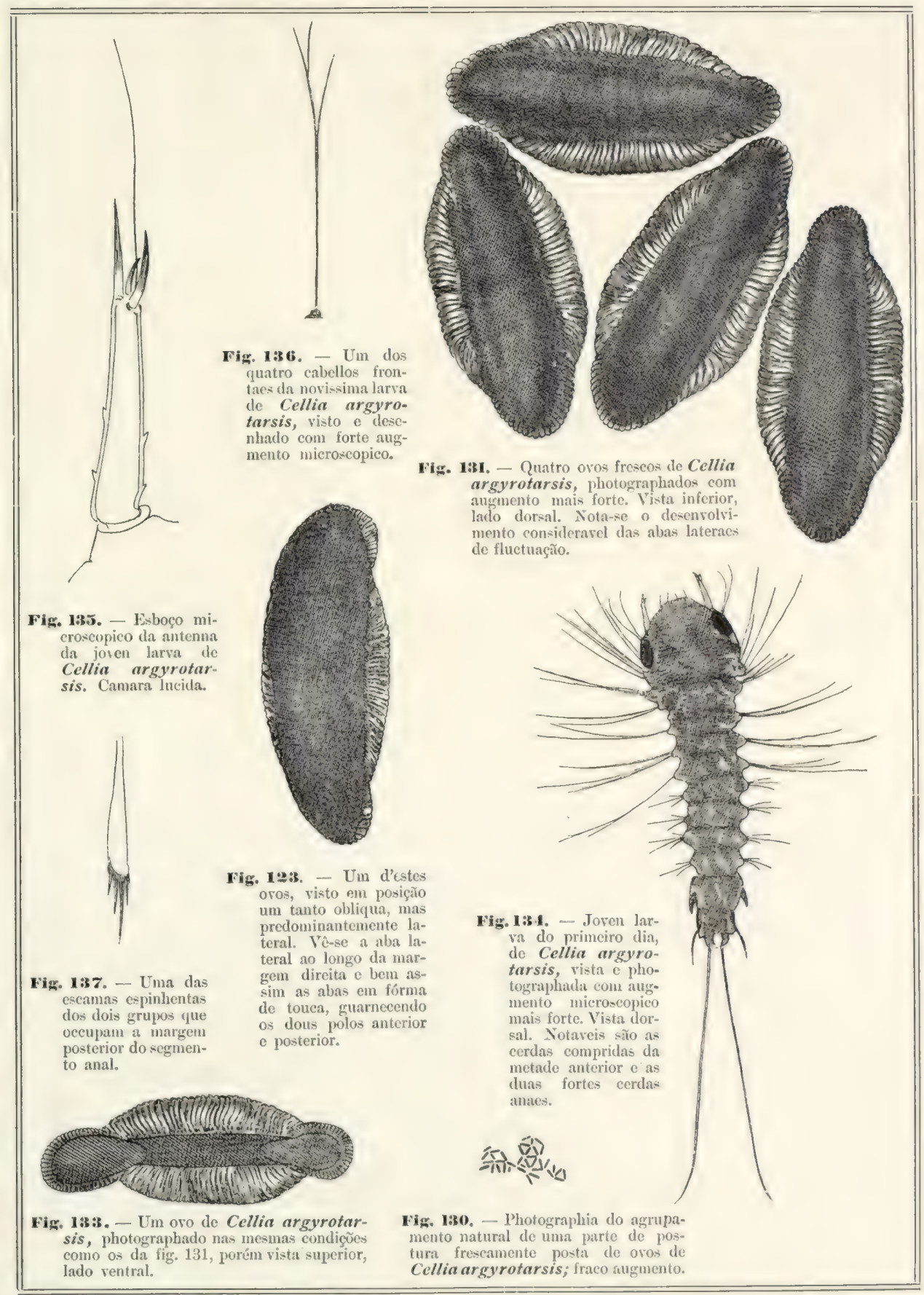

Cellia (Anopheles) argyrotarsis 

tuação usados em certas canoas das Indias, para augmentar a estabilidade. Estes esto. fos invadem ainda não pequena parte dos lados dorsal e ventral do ovo, e deixam livre apenas os dois polos. Estes por sua vez são munidos de uma corôa dos mesmos elementos tubulares, bem visivel nas figuras 132 e 133, qual touca cercando um rosto. Esta corôa é orientada na posição dorso-ventral. Do corpo propriamente dito, visivel como campo preto, percebe-se mais na vista inferior (fig. 131) que na superior (fig. 133).

Não é de todo facil o fazer-se idéa exacta da configuração d'um d'estes ovos. O melhor meio é o indicado por Nuttall e Shipley para a comprehensão do ovo de Anoph. maculipennis: é um bóte, uma canôa com um lado bojudo, exterior maior em superficie e o outro plano, o excavado, menor em superficie; prôa e pôpa com bicos recurvos para dentro. Mediante este recurso e alguma reflexão chega-se tambem a comprehender as nossas figuras, que representam quatro oros, vistos pela face bojuda, exterior, com a qual boiam n'agua (fig. 131), um ovo, visto quasi ląteralmente (fig. 132) e um outro visto pela face interna, superior, excavada e voltada para o ar (fig. 133).

Estes termos "inferior" e "superior» devem ser tomados com a necessaria reserva, pois por multipla discussão anterior tivemos occasião de apprender como regra, que o lado convexo do ovo corresponde á face dorsal do embryão da futura larva, e o lado mais ou menos plano á face ventral. Guiando-nos por esta orientação, vemos que o oro boia, vulgarmente, de costas para a agua, e de barriga para cima.

\section{$+$}

Faz annos já, conheciam-se os ovos do Anopheles maculipennis da Europa e da America do Norte, devido a Grassi, Nuttall, Shipley, Howard e outros. Desde então ficaram conhecidos os ovos das não poucas especies de Anopheles indigenas da India, devido aos esforços de Christophers and Stephens (1), reproduzindo o Sr. Theobald no recente Vol. IV (suppl.), pag. 15, as respectivas figuras. Temos portanto meios para a comparação directa do ovo da nossa Cellia argyrotarsis - até este momento desconhecido, e pelo menos por ninguem descripto e figurado - com o ovo de Anopheles europeus, asiaticos e norte-americanos.

O ovo da nossa Cellia argyrotarsis var. albipes distingue-se de todos os outros até agora descriptos, pelo extraordinario desenvolvimento longitudinal e lateral das azas hydrostaticas, de modo que o diametro transversal está para com o eixo longitudinal na proporção de $1: 21 / 6$. Ao passo que as azas são, a julgar pelas figuras cladas por Grassi, Nuttall, Shipley e Howard, no Anopheles maculipennis, quando muito da metade do comprimento, quasi nada sobresaindo lateralmente, occupam $\% / 3$ ou mais dos lados do ovo da C. argyrotarsis, produzindo nas vistas dorso-ventraes inferiores e superiores possante bojo de cada lado, de maneira que contribuem poderosamente a modificar o aspecto dos contornos do ovo. Entre os Anophelides da India, estudados debaixo d'este ponto de vista por Christophers and Stephens, (Theobald pag. 15) têm na verdade compridas azas tambem os vros de Myzomyia (Anoph.) culicifacies, e M. maculipalpis, 
mas estas azas sómente denotam fraco ou mediano desenvolvimento lateral. Azas largas têm ahi o M. Turkhudi e Ieyporensis Theobald, pag. 41, fig. 6, mas são tambem aqui curtas no sentido longitudinal. Em summa, não ha ovo algum de Anophelide até agora conhecido, que possa ser confundido com o ovo de Cellia argyrotarsis var. albipes.

\section{Larva.}

A joven larva de Cellia argyrotarsis var, albipes, ao sahir do ovo, é uma creatura diminutissima, pois mede sem as compridas cerdas anaes apenas $0,63^{\mathrm{mm}}$, e com

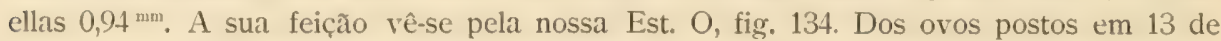
fevereiro de 1905 , a primeira larva foi observada em 15 de fevereiro, dois dias depois; uma segunda em 16 de fevereiro.

O habitus geral d'esta larva concorda bastante bem com a figura que Nuttall e Shipley dão (Est. II, fig. 3) de um "very young larval state" de Anopheles maculipennis, bem assim com a figura dada por Howard, loc. cit. (fig. 18) de uma "young larva " do mesmo Anopheles. Todavia em nossa larva a cabeça é muito mais larga e também possuem um comprimento bastante maior as cerdas anaes.

Quanto aos pormenores da cabeça tenho de constatar que vejo na margem frontal da nova larva apenas 4 cabellos frontaes, simples á primeira vista e com fraco augmento, bifurcados ou trifurcados ao exame mais detido com mais forte ampliação, concordando em geral com a fig. $a$ da fig. 65, pag. 111 do vol, suppl. de Theobald.

[ Estes cabellos frontaes adquiriram importancia recentemente na systematica das larvas do grupo dos Anophelinae, acontecendo que elles em diversas especies da India mostram uma configuração arborescente e mais ou menos complicada composição. (Christ. and Steph. loc. cit. pl. II, Theobald loc. cit. pag. 18, fig. 4) ]. Em relação ás antennas (fig. 135), póde-se definil-as como sendo da fórma de um cône truncado, de moderado tamanho, munido no vertice de dois ganchos reforçados styliformes, tendo no meio uma cerda ou flagello, do comprimento quasi da antenna propriamente. (Compare fig. 6,65 pag. 111 de Theobald). Devo aqui abstrahir de dar descripção e figura da placa labial da larva, porque eu não podia sacrifical-as para o fim da dissecção. Entretanto pelo que vi a feição não differe muito da indicada pelos autores para as larvas de outros Anopheles.

As fortes cerdas lateraes dos segmentos abdominaes, no animal muito joven ainda apparecem, com fraco augmento, como simples pellos; com o emprego de ampliação mais forte nota-se entretanto o inicio da formação dos plumosos, que vemos voltar constantemente nas illustrações de larvas adultas das diversas especies de Anophelinae.

Aos lados e ao dorso da margem posterior do penultimo segmento abdominal (fig. 134) vê-se um pente de elementos espinhentos chitinosos, escuros, que lembram as formações muitas vezes encontradas como "pecten" nas outras larras cle Culicideos. Reproduzimos um esboço de um d'estes elementos com forte augmento microscopico (fig. 137). Compare-se a figura 7 e 7 b. Est. IV, da obra de Grassi, relativa a estes espinhos na larva de Anopheles maculipennis. Engraçada e divertida é a mania d'estas larvas, já n'esta tenra idade de poucas horas, e observadas n'uma gotta d'agua ao mi- 
croscopio, de virar a cabeça para as costas com frequencia. Fazem isto como se esta posição fosse a predilecta, vendo-se que não lhes custa nenhum esforço.

A larva adulta não conheço ainda por propria observação.

O prof. Theobald tinha já em 1901, n'um appendice ao Vol. II da sua obra, pag. $3 \overline{3}$, dado uma noticia muito resumida acerca da larva do Anopheles argyrotarsis var. albipes, extrahida de uma carta do Dr. Grabham, da ilha da Jamaica. Agora elle accrescentou um capitulo inteiro no Vol. IV (suppl.) de 1903 (pag. 110 seg.), sobre estas larvas, com figuras dos pormenores relativos aos cabellos frontaes, antennas e dos folliolos, agrupados em fórma de leque, dos segmentos abdominaes no dorso da larva adulta, e com extensa descripção do habitat e modo de vida, enviada pelo Dr. Low da ilha Dominica. Importante do ponto de vista biologico, é digno de leitura tambem pelo lado da medicina. Entretanto lá nada se diz acerca dos ovos, nem da phase inicial da vida larval.

Reproduzo aqui algumas phrases do Dr. Low relativas á larva e cujo conteudo eu pude verificar aqui no Pará: "The larvae die quickly under artificial cultivation if the water is allowed to become foul. This stage lasts fifteen to eighteen days and the pupal stage two days... (Imago). It is difficult to keep them alive in captivity though feed on blood".

E' digno de nota, que tudo quanto se sabe hoje acerca do cylco evolutivo da Cellia argyrotarsis se refere á variedade "albipes", tanto aqui no Pará, como nas Antilhas e na Guyana. Quanto á especie typica "albitarsis Theobald ", (conforme nossa Estampa colorida II, fig. 10 e 10 a) transparece por uma noticia do Dr. Low, communicada por Theobald, loc. cit. pag. 110, que ella é mais rara em Dominica e na Guyana Ingleza. Tenho a impressão de que isto se repete também aqui no Amazonas. Fica portanto ainda a elucidar por cuidadas investigações futuras, a biologia de C. argyrotarsis-albitarsis, liquidando-se a controversia sobre a validade especifica de ambas, - controversia a que allude o Sr. Theobald loc. cit. pgs. 15 e 16 contra o Coronel Giles.

N'esta occasião não posso esquivar-me de formular uma queixa contra o tal termo "albipes", que em vez de ajudar o discernimento de certa fórma e a retenção do nome, contribue antes para confundir, tanto mais que tem de navegar ao lado do termo "albitarsis " pela especie typica. Não são afinal das contas ambas tanto " albipes " como "albitarsis": Porque não recorrer a uma designaçĩo que elimine, de uma feita. a confusão, escolhendo por exemplo "tarsi-maculata"?

Conviria liquidar assim esta questão de nomenclatura, tanto mais que no caso que se verifica ser "albitarsis" menos frequente por toda a parte do que albipes (tarsimaculata), effectuar-se-ia forçosamente uma inversão no actual modo de encarar as cousas, tomando a segunda, (até agora considerada variedade) como typo da especie, e a primeira (até agora tida por typo da especie) como simples variedade. 
Chironomus calligraphus nov. spec.

(Ovos, larvas e seus pormenores. Est. P., figs. 138-142).

O genero Chironomus, entre os Culicideos, é de certa importancia para nós, não porque incommodasse o homem, como as especies anteriores - nem femea, nem macho possuem um apparelho buccal para perfurar e sugar sangue -, mas as diversas phases do seu desenvolvimento nos caem frequentes vezes na mão, quando procedemos ao estudo methodico da fauna espontanea de um tanque nas nossas hortas.

O insecto adulto, a imago, é um mosquito delgado, na maioria esverdeado, facil de conhecer pela circumstancia de serem as suas azas consideravelmente mais curtas que o abdomen, o qual fica com quasi $2 \frac{1}{2}$ segmentos anaes a descoberto. As antennas, curtas em ambos os sexos, são plumosas no macho, e verticilladas, equisitaceas na femea. Quando vivo, póde ser reconhecido facilmente o Chironomus pelo costume de levantar, quando repousa, as pernas da frente, ao passo que a maioria dos mosquitos haematophagos, tratados na presente memoria, levantariam, em identico caso, as pernas posteriores. (Conf. Est. I, fig. 2: femea de Stegomyia, „em posição de repouso).

Quando examinamos as paredes com limo verde, de uma tina d'agua no jardim ou de um tanque na horta, ás vezes as encontramos cheias de umas pequenas gallerias verdes, que depressa se reconhecem como esconderijos de uma larva vermiforme avermelhada. São larvas crescidas de Chironomus (fig. 142). E quando investigamos a superficie d'agua de taes depositos, não é raro depararmos n'uma manhan umas exquisitas, elegantes fórmas de fios muito tenues, arrumados talvez n'uma duzia de zig-zags regularmente equidistantes. São os cordões de ovos de Chironomus (figs. 138 e 139 ).

Nada mais interessante do que o exame de um cordão de ovos de Chironomus (fig. 138) quando examinado com agua limpida n'um vidro de relogio, mediante uma lente. Resolve-se então o conjuncto como sendo uma multidão sem cónta de ovos, acomodados dentro de uma fita gelatinosa que lhes serve de berço e de boia. Empregando ampliação maior (fig. 139) apresentam-se os bellos ovos com nitidez que nada deixa a desejar. São relativamente grandes, uniformes, oblongos; ambos os polos são arredondados. Caracterisa-os outrosim a linda mancha verde, que costuma occupar porção central do corpo maior ou menor. No caso da nossa microphotographia os ovos achavam-se n'uma phase bastante avançada, deixando já perceber muito bem a segmentação do abdomen, o limite entre as zonas thoracica e abdominal e os olhos, reconheciveis como pontos escuros na parte anterior.

As novas larvas, ao irromper da casca ovular, passeiam ainda algum tempo nos lados do fio gelatinoso, dando a impressão de uma rua de cidade populosa, com a multidão de transeuntes em ambos os passeios lateraes. São muito ageis e sobremodo transparentes. O seu aspecto geral se vê pela nossa figura 140, representando uma larva de ha pouco nascida. Cedo já possúe todas as particularidades que caracterisam a larva adulta de Chironomus (fig. 142), e que são principalmente os pés cylindricos ( «fausses pattes antérieures Meinert), sitos na frente e atraz, e armados de uma corôa 
de ganchos, os sacos transparentes em certa zona da região ventral dos ultimos segmentos ("protubérances rétractiles en forme de boudin» Meinert) e o tufo anal («soie anale" Meinert). Sem pretender entrar em mais detalhes, limito-me a frizar que a larva de Chironomus affasta-se, no seu aspecto, das dos mosquitos haematophagos antes tratados, por um que de vermiforme bastante accentuado; também a comparação com as lagartas de certos Lepidopteros, principalmente das Noctuidas, não iria mal. Quanto á chrysalida do nosso Chironomus paraense posso dizer que elle é, como aliâs as outras todas, vermelho sangue, contrastando esta côr com a dos dous tufos brancos de cabellos sitos no alto da cabeça. A substancia rermelha é hemoglobina. Conf. Miall op. cit. pagina $130 \mathrm{seg}$.

A respeito da postura dos ovos, respectivamente ao seu agrupamento, Miall no seu util livrinho (1903), pag. 147 descreve e figura os cordões de diversas especies de Chironomus europêos, accentuando a existencia de extranhas differenças. Semelhantes costumes têm outrosim os membros do genero Tanypus, e curioso é que o nosso Chironomus paraense se approxime bastante, no arranjo em zig-zag, ao disco de ovos figurado por Miall pag. 153, fig. 44 para o $\mathrm{T}$. maculatus. Todavia não se trata de um Tanypus no nosso caso, mas positivamente de um Chironomus, o que não é difficil de asseverar á vista do habitus profundamente diverso das larvas de um e de outro.

As especies brazilicas dos generos Chironomus, (1) Corethra, Ceratopogon e outros, todos Culicides aparentados, não haematophagos, são ainda muito mal conhecidas; por assim dizer nada se sabe d'ellas, nem pelo lado systematico, nem pelo lado biologico (2). Ainda fica muito a fazer n'este terreno para as geraçues futuras, que, Summo Divino Numine, prestarão mais attenção ao estudo da natureza do que a actual.

1) Chironomus holoprasinus nov. spec. Goeldi (1905)

\section{Imago $\sigma^{7}: 5,5$}

Palpos de 7 articulos cylindricos: I curto; II e III compridos, iguạes quasi; IV, o mais comprido.

Antennas plumosas equisetaceas de 12 articulos, ( 2 verticillios de cabellos em cada um) dos quaes os 11 basaes curtos, o 12. muito comprido.
Aspecto de todo o corpo (menos a cabeça, que é preta; os palpos, côr de ambar), o thorax brunnaceo), as azas (lyalinas, iridescentes)] de um rerde amavellaceo nas extremidales, mais retinto (prasinus ) no dorso dos ultimos seymentos abdominaes.

Thorax: brunnaceo, com 3 estrias escuras longitudinaes uma recta mediana, 2 curvas lateraes coneavas.

(1) Existe, na verdade, um Chironomus brasiliensis, descripto, já em 1828 , por Wiedemann, é proveniente forém de Montevideo e a descripçio é de tal maneira curta que me fica duvidoso se haverá quem possa, com serurança, reconhecel-o.

Ha outrosim mais trez especies provenientes nominalmente do Brazil: $\mathrm{Cl}$. ferrugineus Macq., Ch. insignis Wiedemann e Cl. trimaculalus Macq

(2) Quiz a principio mencionar a especie presente do Para simplesmente como Cijironomus spec. Na ultima hora porém resolvi de descrever as duas espeçies mais frequentes aqui no Parí, de modo que ficassem reconheciveis para sempre. As observaçũes acima contadas refezem-se á especie maior entre estas duas, Cls, calligraphus. 


\section{Imago $\odot: 5,5^{\mathrm{mm}}$.}

Palpos de 5 articulos cylindricos.

Antennas de 6 articulos em fórma de pote, sendo o 2.0 e o $6 .^{\circ}$ (cylindrico) os mais compridos.

Pernas: par I: fuliginoso a tibia em toda a sua extensão, e em grau diminutivo todo o resto distal da perna.

\begin{abstract}
Peruas: pallidamente verde anarellaceas nas partes medias, un tanto mais escuras nas partes distnes. Par I assaz comprido como em todos os Chironomus): artieulaçăo femorali-tibialis : fuliginoso como chamuscado o ultimo sexto do femur; o primeiro terço medial (interno) da tibia e bem assim o ultimo sexto da mesrun tibia contra a articulaçòo tibio-tarsal. Pares II e III: tuliginoso-escuro sómente a zuna terminal muito estreita, com o respectivo espinho lateral, da tibia, na articulação tibio-tar:al.
\end{abstract}

Muitos $\sigma^{7} \sigma^{7}$ e $\& \&$, apanhados nos tanques d'agua do horto botanico do Museu (fevereiro - março de 1995 ) e criados de larvas.

Especie frequentissima no Pará, facil de conhecer á primeira vista pelo seu delicado colorido geral verde e sua pequena estatura, sobretudo quando comparada com a especie seguinte.

\section{2) Chironomus calligraphus nov, spec. Goeldi (1905).}

\section{Imago $\sigma^{7}: 7,5^{\mathrm{mm}}-8,5 \mathrm{~mm}$.}

Palpos de 4 articulos cylindricos, dos quaes o $2 .^{\circ}$ e o $30^{\circ}$ iguaes.

Antennas plumosas, equisetaceas, de 12 articulos, o $120^{\circ}$ muito comprido. Na barba da antenna alternam zonas largas mais escuras e mais claras.

\section{Imago $\&: 7,5^{\mathrm{mm}}-8,5^{\mathrm{mm}}$.}

Palpos de 5 articulos cylindricos.

Antemas de 6 articulos, em fórma de pote, sendo o $2 .^{\circ}$ (com estreitamento no meio ) e o $6.0^{\circ}$ (cylindrico) os mais compridos.

Aspecto geral brunnaceo, lembrando quanto ao colorido um tanto as Tipulas. - Cabeça escura no aspecto frontal, devido á grande extensão dos olhos. Palpos e hastes das antennas um ponco mais retintas do que as pernas.

Thorax: brunnaceo, com 3 estrias longitudinaes brunoescuras, 0.5 intersticios branco amarellaceos. O metathorax fuliginoso-escuro, quasi preto.

Azos: hyalinas, iridescentes.

Abdomen: Segmentos anteriores meio claros, os dous ou tres posteriores escuros. Margem fortemente encabellada por toda a parte. Em cada segmento uma figura triangular, cuneiforme, bruna-escura, com base แa margem anterior, atraressa o lado dorsal, abarcando ainda parte dos lados e empresta ornamentação caracteristica ao abdomen.

Pernas: branco-amarellaceas. Par I (comprido): um pouco mais escura (chamuscada) o ultimo sexto distal do fernur, c o primeiro terço medial da tibia. Par II e III : fuliginoso eseuro, quasi preto, uma estreita zona terminal em todas as articulações tarsaes, sendo sobretudo distincta a tibio-tarsal.

Numerosos $\sigma^{7} \sigma^{7}$ e $q \odot$ apanhados e criados nos mesmos logares aqui no Pará, e de sociedade com a especie anterior, (fevereiro e março de 1905) e da qual facilmente se distingue pelo seu tamanho mais avantajado e o seu colorido brunnaceo.

O novo nome especifico "calligraphus" foi proposto em attenção á notavel belleza da linha que descreve este Chironomus com o seu cordão de ovos.

B. - Conhecem-se actualmente umas 320 especies de Chironomus de todo o globo (conf. Kertész "Catalogus Dipterorum hucusque descriptorum». (Leipzig 1902 Vol. I, pag. 181 - 207) e da America do Sul constam-me 31 especies ao todo (confer Hunter "Catalogue of the Diptera of South-America ». Part. I : Nemocera: Transact. American Entomolog. Society Vol. 26, 1900, pag. 282 - 283. 


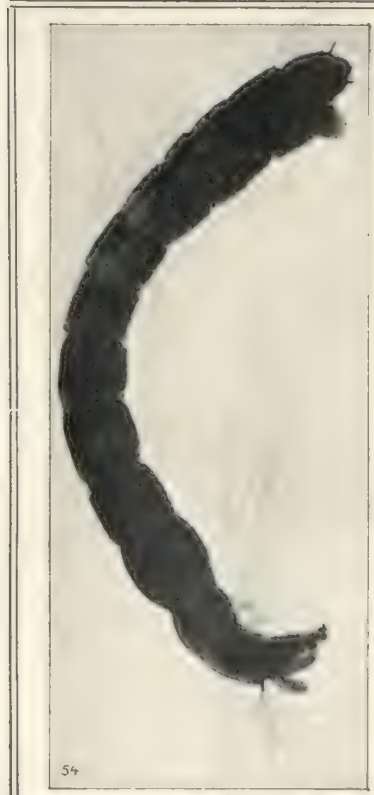

Fig. 112. - Larva já crescida de Chironomus calligraphus, vista com fraco angmento. Pelo lado anal, face abdominal, aperceben--e uns saceos finos, transparentes, que têm a mesma funcçăo respiratoria. como os folliolos branchiaes da regiño anal das larrax dos Mosquitos trpicos. I larva de Chironomus, n'esta phase de vida, já habita n'uma galeria protectora, por ella fabricada com fragmentos de alyas, etc., e por isto de côr rerde.

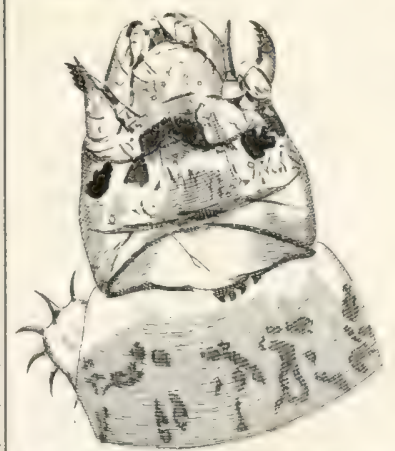

Nig. 111. - Cabeça da mesma larva, photorraphada com augmento mais forte. Vista rentral.

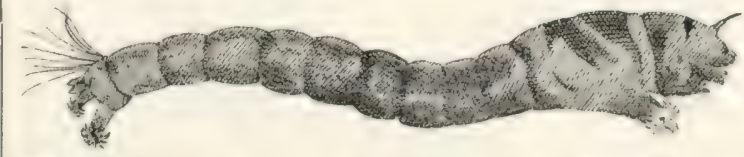

Wig. 140.-Joren larra, apenas sahida do oro, do Chironomus calligrophus, photographada com augmento mieroscopieo moderado. Notase na frente um par de pés, coni ganchos curros en roda; outro par encontra-se no ultimo segmento abdominal.

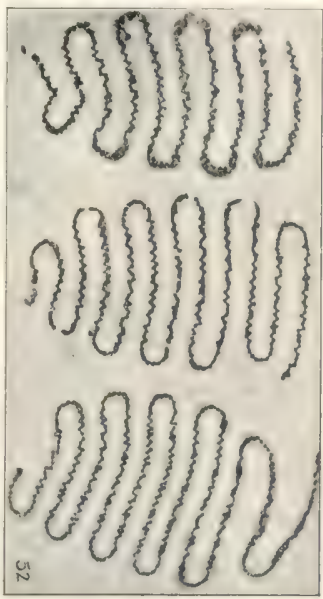

Nis. 1iss. - Trez cordües de ovos, na liberdade frescamente postos na superficie d'agua de um tanque por Chironomus calligraphus, mosquito não chupador de sangue e desprovido de proboscida propria para furar a pelle de outros animaes. Vêquisito em linhas de zig-zac. liruo augmento, vista photugraphicat.

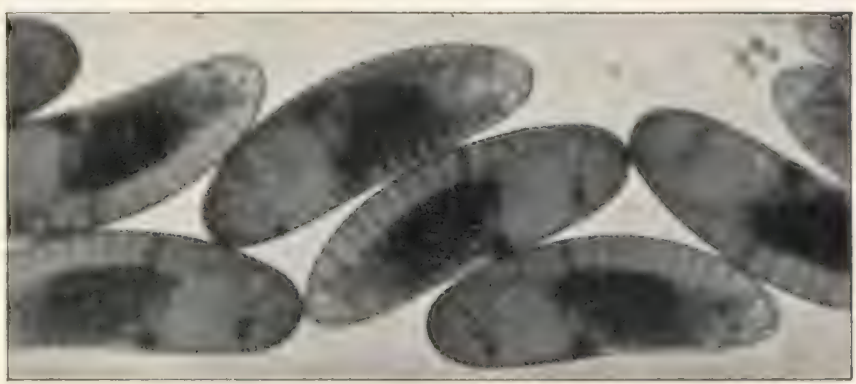

Niqu. 1339. - Certa poreão de un d'entes cordžes de Chironomus, rista com au gmento microscopico mais forte. Os ovos no seu amrupamento uatural mustram tum colorido esverdeado devido ao seu conteudo e acham-se já en adiantada phase de desenvolvimento, tramsparecendo distinctumente a semmentaçäo das larvas. Os ovos sto acamalos na massa gelatinosa e viscosa dos cor löes, semelhantes con tudo aos que fabricam as femeas dos sapos (Bufonides).

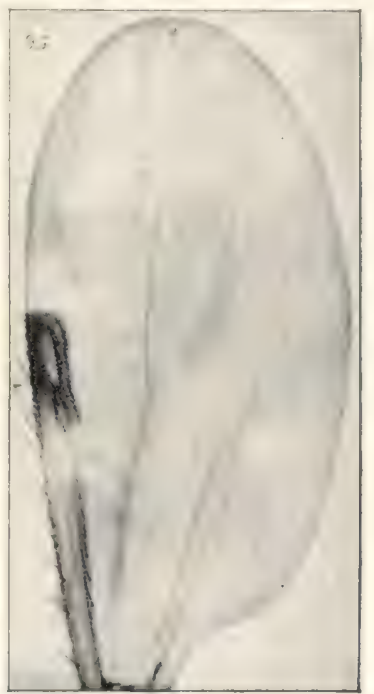

Vig. 11. - Vista7photographiea de uma aza do mesmo "meruim", com ampliaço ainda mais consideravel, para auxiliar o reconhecimento dos pormenores systematicos.

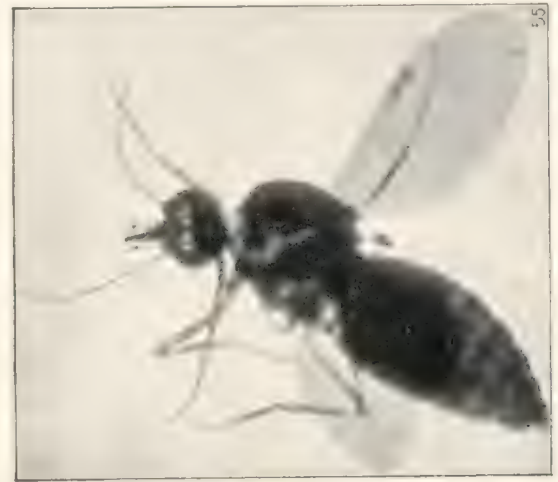

Fis. 113. - Vista photogranhica de um "meruim”", (Haematomyidium paraense (i.) diminutissimo Diptero haematophago, assaz incommodativo na rerião amazonica, especialmente no littoral o na zona sujeita ais marés. Nấo é mosquito (Culicideo) proprianente dito, mas uma pequena mosea. Augmento microseopico assaz forte.

Chironomus calligraphus G. - (Fig. 138-142) "Niruím" (Haenuatomavidium paránense G.) 



\section{"Miruim" - (Haematomyidium paraense nov. gen. et spec.)}

(Insecto adulto alado e pormenores da aza - figs. 143 e 144).

No caso do insecto em questão trata-se, na verdade, não de um Culicideo (Mosquito), mas sempre de um Diptero, de uma mosca minuscula. E' haematophago "confesso e relapso ", um verdadeiro flagello e peste em muitos pontos do littoral, nos arredores do Pará, muito afamado e conhecido por todos. E' diurno, atacando a qualquer hora e deixando sempre ao redor da picada uma inflammação assaz consideravel. Seu diminuto tamanho the permitte atravessar perfeitamente as malhas de um mosquiteiro usual, de maneira que não ha contra elle garantia alguma. Entra nas casas e dias houve já em que apanhamos, em poucos minutos duzias d'elles com tubos de ensaio. Sua frequencia periodica parece-me estar em relação com as marés, pois é na baixa maré que o "meruim" por via de regra se faz sentir com as suas invasões.

Na consegui obter por ora a definitiva determinação scientifica do "miruim", que entretanto está affecta á solução por parte dos autorizados Dipterologos de além. mar. (1).

O "miruim " é uma diminutissima mosca, menor ainda que o "piúm " amazonico e o pendant meridional d'este, o conhecido e temido "borrachudo ». Pelas antennas compridas, nas quaes conto 14 articulos em fórma de pote, cada um com alguns poucos cabellos insertos na parte distal e arrumados em fileira transversal, elle lembra de certo modo os Dipteros nemoceros do parentesco de Cecidomyia e Tipula. A aza, de

(1) Resolri na ultima hora denominar e deserever summariamente o * miruim " paraense para acabar finalmente com esta afflictiva situação de incerteza que já por demais tempo dura acerea da sua posição systematica.

\section{Haematomyidium nov. genus.}

\section{(úuce = sangue; uzíliov = pequena mosea).}

Diminutissimas moscas nematoceras, haematophagas, diurnas, (menores ainda $\mathrm{cm}$ calibre do que as especies de Simulium ); de estatura rechonchuda, curta e grossa; de cabeç grande, redonda; de proboscidle curta, styliforme; palpos pouco maiores de 5 articulos, dos quaes $020^{\circ}$ e $03 .^{\circ}$ conpridos; antennas longas de 14 articulus, dos quares 0 s distaes alongados, ponco encabellados; abdomen curto, largo e grosso, ovoide; asas fuliginosas, annuviadas, largas e arredondadas, de nervatura simplificada, lembrando a das Mycetophilides (Seiara) por um lado e das Cecidomyias por outro lado, guardando posiçăo intermediaria entre ambas. Vena subcostalis (II) extendendo-se até além da metade da margem anterior costal; vena radialis (III) simples, atravessandu longitudinalmente toda a aza e terminando na margem exterior; vena média (V), igualmente simples, desde a sua origem no canto humeral até a sua terminação; vena cubitalis (VII) bifureada no nltimo tercu distal. (Confere fig. 1.14). - Macula anterior costal preta-fuliginosa e outrosim toda a margem anterior fuliginosa. - Ité arora uma unica especie, neotropica. - 'Typo: H. paraense (190.5) do Pará.

Haematomyidium paraense nov, spec. Goeldi (1905).

Habitus geral da inago feminina (오 ) visivel na figura 143. Colorido em vida um azulado cinzento. A aza E atravessada de cima para baixo, por quatro séries de grandes espaços claros redondos (janellas) em campo geral Jigeiramente escuro. Estas conspicuas janellas disscminadas subre os intervallos entre as reias da parte distal da aza geiramente esco $2,3,3,3$ (de fora para dentro), enchendo quasi os respectivos vãos. Campo das azas crisado de pequenissimos cabellos curtos, entre os quaes se perceben algo maiores, rerularmente acompanhando o percurso lonpequenissimos cabellos curtos, entre os quaes se perceben algo maiores, regralarmente acompanhando o percurso longritudinal das veias; circumfereneia guarnecida de cabellos um pouco mais fortes, os mais robustos encontrando-se na
margem antero-medial. Fitas claras transversacs atrovez das articulaçoes trochanter-femur e femur-tibia dos dois pares de pernas anteriores. (I e II) e uma fita clara atravez da parte medial da tibia do terceiro par (III), perto da articulacão tibio-femoral. Um forte espinho lanceolado pelo lado externo da tibia, na articulaçăo tibio tarsal. Dimensües: C'onsào primento total 1,

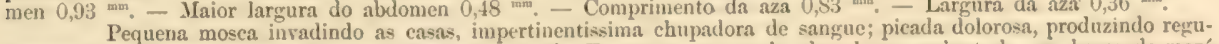
larmente uma zona circular inflammada bastante grande. Frequente na cpocha das chuvas, sobretudo nas horas de maré baixa, o que parece apontar para uma creatura littoral. Pará e arredores. Some local, indigena * Miruim » i. e. merú = mosca e $i_{\text {。 }}$ (abrev. de mirim) = pequena. (Descripção mais detallada será dada opportunamente). 
simpl:cissima estructura e nervatura, por sua vez lembra algum tanto a Cecidomyia e talvez Lasioptera.

Não quadrando nos seus pormenores essenciaes o "miruim" com descripção generica e illustração alguma da literatura dipterologica á minha disposição, não seria de estranhar que os especialistas se vissem obrigados a fazer d'elle grupo e genero totalmente noros.

Escreveu o Dr. Lutz n'um recente artigo intitulado "Nota preliminar sobre os insectos sugadores de sangue, observados nos Estados de S. Paulo e Rio de Janeiro " (Rio de Janeiro, 1903) pag. 7, em relação ao Sul do Brazil que "os dipteros, conhecidos pelos nomes de polvora, mamim e mosquitinhos do sangue são nematoceros e pertenbem ao genero Ceratopogon". Ora isto não procede quanto ao nosso "miruim " amazonico. Ceratơpogon, é um genero de Culicideo eucephalo, do proximo parentesco dos Mosquitos que fazem objecto da presente memoria, as imagines, embora pequenas, são sempre muito maiores do que em nosso "miruim" paraense, e ostentam vistosa antenna plumosa, donde lhes veiu o nome scientifico (Veja Cuvier Règne Animal, Insectes Atlas Vol. II, pl. 161 fig. 7). Encontro de vez em quando larvas e pupas (esta facil de reconhecer pelo seu habitus estranhamente espinhoso) de um Ceratopogon indigena aqui no Pará, em agua depositada no vão de Bromelias no horto botanico do proprio Museu. (Tanto quanto sei, ainda não ha especie alguma de Ceratopogon até hoje descripta do Brazil. (veja Hunter, Catalogue of Diptera of South-America, 1900. Part. I, pag. 284).

Quanto ao "pium " de tão desvantajada reputação em certas regiões amazonicas, sobretudo no rio Purús, quero sómente de passagem constatar que é igualmente uma mosquinha diminutissima, e que não ha para mim duvida alguma, de que faz parte do genero Simulium, (1) fornecedor de uma porção de fórmas haematophagas por quasi todas as partes do mundo. Como tal o caracterisam logo a antenna de 10 articulos curtos cylindricos, sendo os da base mais largos e grossos e sobretudo a notabilis-

(1) Resolvi observar igual procedimento relativo ao «piúm», como adiante a respeito do «miruim \$. Não podemos esperar eternamente até que venha especialista que por favor nos dê um nome e descripcìo para cstas ereaturas tăo importantes na nossa vida quotidiana. Proponho portanto denominar o nosso s piúm * seientifieamente:

Simulium amazonicum nor. spec. Goeldi (1905)

Imago 오 : Colorido geral : ennerrescido. - Antemuer de 10 articulos. dos quaes I e II (basaes) maiores, o ultimo $(\mathrm{X})$ conico; colorido uniforme, brumaceo. -- Thorax: Lado dorsal, colorido dominante em cinzento azuladoprateato, no qual se destaea um desenho caracteristico de côr preta, com muitos lindos eabellos dourados pelo campo todo e prineipalmente pela margem exterior do desenho; este constitue-se 1) de uma estria recta mediana 2 ) de dua linhas curvas em fórma de semilua, combinando-se com a mediana, de maneira a formar mais ou menos um $T$, virado para-a frente (Poderia-se assin fallar de 5 linbas thoracieas longitudinaes). - Pernas: I par: femur elaro, (somente o Indo distal um pouco chamuscado) tibia toda e tndo o tarso friiginoso-escuro. - II par : clara em toda extensato, com uniea excepçąo talvez de serem un bocadinho chamuscadas todas as articulaçũes, pelo lado distal. desde a tibiotarsal; “. III par: escuro o femur, a metade distal da tibia, o ultino quarto distal do tarso e o terço ou a metade distal dos outros articulos tarsaes. (E' muito earacteristico o colorido das peruats, sobretudo do tereciro par bicolor. Halteras: amarellas esbranquiçadas, contrastando fortenente coni a côr escura do abdomen. - Asas : bellamente irisantes, com matizes dourados; aliás moldadas conforme feitio e nervatura usuaes no genero simulium.

(Vena cubital, com os seus dous ramos VII ' e VII ${ }^{2}$ assaz difficil de ver, nórmente a segrunda). - Aludomen fuliginoso, aliás sem desenhos e mareas especiaes. - Dimensûcs: Conprimento total 2,06 ${ }^{\mathrm{mm}}$. Comprimentu da antenna 0.3.5m. - Largura do thorax: $0.86^{\mathrm{rmm}}$. - Comprimento do nblomen 1,12 ${ }^{\mathrm{mm}}$. - Maior largura do abdomen $0,58^{\text {man }}$ - Comprimento da aza $1,6^{\text {min. }}$ - - Largura da aza $0,91^{\text {mm. }}$.

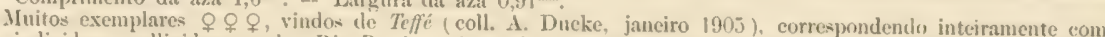
numerosos individuos, colligidos no alto Rio Purís e Acre (Dr. J. Huber e commisato do Juseu 1904- 1905 ) e eun. 
sima aza, com a sua extranha curva postero-interior e a "vena analis", curva em fórma de S, que por si só seria sufficiente para logo trahir um membro do genero Simulium.

Quanto ao "borrachudo " do Brazil meridional declara o Dr. Lutz loc. cit. pag, 7, que este igualmente entra no genero Simulium, communicando ter achado por lá mais tres especies.

Tanto quanto me consta existe até hoje uma unica especie descripta do Brazil (é o S. nigrimanus Macq. (1838) do Estado de S. Paulo), permanecendo as outras ainda indescriptas.

No nosso "piúm" amazonico ha concordancia generica com os caractéres das especies norte-americanas por exemplo, de Simulium, que encontro figuradas na bella obra de Felt "Aquatic insects in New York State ", Est. 34 fig. 1, - Est. 36, fig. 7.Est. 37, fig. 8.

As larvas de Simulium, como se vê pelos autores norte-americanos são aquaticas e adherem, parecendo com Actinias maritimas ou com certos Rotiferos, a pedras, plantas aquaticas. etc. nos rios de alguma correnteza. (Miall op. cit. pag. 176, fig. 59 - Felt op. cit. Est. 34, fig. 9). Não me tendo sido possivel descobrir até agora a larva do "Miruim" nem do "piúm " nem o seu escondrijo e paradeiro predilecto, não me vieram ainda por este lado dados que auxiliassem a definitiva collocação d'estes insectos no systema. Absolutamente nada ainda me consta na literatura scientifica actual sobre este assumpto.

\section{Synopse resumida sobre a composição de algumas collecções de Mosquitos feitas em diversos pontos da região amazonica pelo pessoal do Museı durante os ultimos annos.}

Tendo sido objecto de constantes recommendações nossas aos emissarios do Museu, de prestar a maxima attenção aos Mosquitos dominantes em cada uma das localidades visitadas no interior, veio se encontrar em nossas mãos, no correr dos ultimos tres annos, um bello contingente de colheitas locaes de Culicideos. Creio opportuno o momento, para dar em succinta synopse uma idéa da composição d'estas colheitas, synopse que não deixa de merecer interesse a mais de um respeito. Aliás a semelhante

servados en alfinetes e no alcool. (Uma série de co-typos foi remettido ao British IItseum em Londres, d'este " piúms alto-amazonico, como do imiruím p paraense). - Figuras illustrando os pormenores serão publicadas opportunamente. T. B. - Is especies de Simulium norte-americanas já estão bastante ben estudadas, como se vê pela obra de Felt - Aquatic Insects in New York States (1903) pag. 336 - 388. Conhecem-se lá nada menos do que umas 40 especies (importando o total das especies do globo inteiro actualmente descriptas approximativamente $\mathrm{en} 80$ ), entre as quaes algumas como S. pictipes e S. pecorzm tem uma importancia economica como inimigos da criação de gado. (Nas baixadas do Danubio, na Europa, é desde muito celebre praga o Simulium columbaschense). O nosso " piúm * alto-amazonico parece approximar-se, como jrosso conchir da chave synoptica (Felt loc. cit. pag. 3jt seg.), de certa especie cubana ( $\mathrm{S}$. quadrivittatum) pelo colorido geral escuro e a ornamentaçăo thoracica.

Es assaz surprehendente que entre os antigos naturalistas exploradores do valle amazonico nenhum tivesse provocado um estudo acurado e a determimação do jiúm, por parte d. 4 m epeciali-ta. Fintretanto não deixam de fallar d'elle (conf. Bates ₹ Naturalist on the River Amazon s, Reprint 1892, pag. 170 seg., Herbert Smith " Brazil, the Amazons and the Coast pag. 334 etc.) Bates contenta-se em declarar que o * piúm *, tão molestador no Río Solimẽes, Amazons and the Coast pag. 331 etc. simulium comportamento differente, circumstancia que o leva a suppor a existencia de diversas especies de a piúms amazonicas. 
tentativa não se poderá contestar um merecimento:- é a primeira vez que alguem ousa abordar o problema ca distribuição geographica dos nossos principaes Culicideos haematophagos, em relação á uma certa, e determinada zona do territorio brasilico. No fim alludirei á algumas das principaes conclusð̃es, que d'ahi se podem tirar.

Limito-me na presente lista a umas 10 especies das mais importantes, deixando de lado o que as respectiras colheitas possam conter em outras especies de Culicides de alcance secundario.

1. Rio Trombetas. (Oriximina ).

Data: julho, 1903. Colleccionador: A. Ducke.

Sabethes 2 individuos.

2. Obidos.

Data: julho, 1903. Collec.: A. Ducke.

Ianthinosoma Lutzii 1.

Panoplites titillans 3 .

Taeniorhynchus fasciolatus 1.

Data : janeiro, 1904. Collecc. : idem.

Ianthinosoma Lutzii 39.

Panoplites titillans 3.

Sabethes 1.

3. Alemquer.

Data: julho, 1903. Collecc.: A. Ducke.

Anopheles argyrotarsis 9.

Panoplites titillans 12 .

Sabethes 1.

4. Parana de Paranaquara.

Data: maio, 1903. Collecc.: A. Ducke.

Ianthinosoma Lutzii 2.

Ianth. musica 1.

Panoplites titillans 7.

5. Prainha.

Data: maio, 1903. Collecc.: A. Ducke.

Ianthinosoma Lutzii 3.

Panoplites titillans 1.

Taeniorhynchus fasciol. 1.

6. Almeirim.

Data : abril, 1903. Collecc.: A. Ducke.

Megarhinus 3.

7. Arrayollos.

Data: abril, 1903. Collecc.: A. Ducke.

Anopheles argyrotarsis 3.

Ianthinosoma Lutzii 3.

Panoplites titillans 3.

Taeniorhynchus fasciol. 4. 
8. Rio Xingi (Proridencia).

Data: dezembro, 1903 - janeiro, 1904. Collecc. I. Bach.

Anopheles argyrotarsis 11.

Ianthinosoma Lutzii 247.

Panoplites titillans 18.

Culex serratus 3.

9. Rio Tapajos (Itaituba).

Data: agosto, 1902. Collecc.: A. Ducke.

Sabethes, muitos.

10. Faro.

Data: julho, 1903. Collecc.: A. Ducke.

Panoplites titillans 3.

Sabethes 1.

11. Teffé

Data: setembro, 1904. Collecc.: A. Ducke.

Anopheles argyrotarsis 4.

Ianthinosoma Lutzii 8.

Panoplites titillans 14.

Sabethes 7.

Megarhinus 5 .

Trichoprosopon nivipes 2. - ( Piúm» muitos).

12. Rio Iapuré.

Data: novembro, 1904. Collecc. :-A. Ducke.

Panoplites 2.

Sabethes 1.

Melanoconion atratum 17.

13. Tabatinga.

Data : outubro, 1904. Collecc.: A. Ducke.

Panoplites titillans 1.

Sabethes 4.

Melanoconion atrat. 2.

Taeniorhynchus fulvus 1 .

14. Rio Purus e Rio Acre.

Data: março - junho, 1904. Collecc. : Dr. J. Huber.

Anopheles argyrotarsis (muitos).

Ianthinosoma Lutzii (muitos).

Panoplites titillans (muitos).

"Piúm" (muitos).

15. Oyapoc. A. Porto Fiscal:

Data: junho, 1904. Collecc.: A. Ducke.

Ianthinosoma musica 3.

Taeniorhynchus fasciol. 1.

Sabethes 15.

Trichoprosopon 3.

Melanoconion atratum 7. 


\author{
Limatus Durhami 1. \\ B: "Ponta dos Indios" casa na beira do campo alagado: \\ Data: junho, 1904. Collecc.: A. Ducke. \\ Anopheles argyrotarsis 10. \\ Taeniorhynchus fasciolatus 16. \\ Limatus Durhami 1. \\ 16. Amapa. \\ Data: julho, 1904. Collecc.: A. Ducke. \\ Anopheles argyrotarsis 5. (1) \\ Panoplites titillans 5. \\ Taeniorynchus fasciol. 1. \\ Melanoconion atratum 11. \\ Stegomyia fasciata 1.
}

Entre as primeiras impressões, que resultam de um exame critico d'estes dados, é por um lado a phenomenal extensão de algumas das especies das mais affamadas entre os Culicides haematophagos, e por outro a composição quer relativa, quer absolutamente semelhante das colheitas de mosquitos feitas em diversos pontos, por vezes muito distantes uns dos outros. Um mosquito diurno, impertinentissimo flagello para quem tiver o que fazer no mato, é por todo o Amazonas e os seus tributarios a Ianthinosoma Lutzii, collocando-se ao seu lado o Anopheles argyrotarsis, nocturno, no fundo, mas diurno na mata sombria e no "ygapó ".

O Panoplites titillans, nocturno, e assaltador das casas, vem em terceiro logar e segue-o logo o Taeniorhynchus fasciolatus, de costumes identicos. Facto digno de attenção é de certo, que em algumas das colheitas, sobretudo na do Rio Japurá, os accostumados picadores severos são substituidos em grau maior ou menor pelo Melanoconion atratum, um genuino Culex, que me é familiar das matas dos arredores do Pará, como frequentemente associado ao Limatus Durhami e a Joblotia nivipes. Aliás, claro é que a época influia sempre também poderosamente na composição da colheita, tanto que é de presumir que repetida em outra estação no mesmo logar, bem diverso conjuncto apresentaria. Também é obvio que mosquitos tão extraordinariamente beilos como são as especics de Sabethes e de Megarhinus sempre tentarão o colleccionador. Quanto ao Anopheles não deixa de ser bastante curioso sob o ponto de vista sanitario, que logares como Alemquer, bastante flagellados por este mosquito gozam da fama de localidades saudaveis, onde raros ou desconhecidos são os casos de febres palustres. Taes casos mereceriam um estudo attencioso pelo duplo prisma da questão medica e do problema biologico. - Exemplares amazonicos de Anophiles vieram até agora ás nossas mãos das seguintes lodalidades: Pará e arredores; residencia directorial do Museu; 
Forno do lixo; Santa Izabel; Murutucú; Fazenda Itacuan, Guamá (setembro, 1903); Alemquer (setembro, 1903); Arrayollos (abril, 1903); Rio Xingú (janeiro, 1904); Teffé (setembro, 1904); Rios Purús e Acre (março e abril, 1904); Oyapoc (junho, 1904); Amapá (setembro e outubro, 1905; agosto, 1904); Macapá, 1899).

Systematicamente é digno de nota (e tomo a liberdade de referir-me ao que já disse em algumas paginas atraz) que todos os exemplares de Cellia (Anopheles) que actualmente ainda possúo, com excepção de um, pertencem á tal variedade "albipes " de Theobald, minha "tarsi-maculata", que um só individuo do Amapá representa o que se considera a especie typica C. argyrotarsis-albitarsis. Isto então será sempre e por toda a parte mero accaso? - A Stegomyia fasciata foi observada, pelo pessoal do Museu, que está exercitado já n'este terreno, fóra da cidade de Belém nas seguintes localidades do interior: Manáos, - Obidos (A. Ducke), isoladamente. - Santarém (A. Ducke), isoladamente. E objecto de bastante sorpreza para mim constitue um exemplar d'este famigerado Culicidio, que o mesmo nosso entomologista trouxe recentemente do Amapá. (1)

(1) Por incommoda que seja a praga dos mosquitos nesta capital, facilmente julgaria exaggeradas as descripções dadas por Humboldt e outros viajantes celebres quem nunea da cidades de Belém ou Jaúos tivesse sabido a pereorret certas regiōes pantanosas do interior dos duis Estados amazonicos. Tendo eu, nas minhas excursũes em servico do Yuseu, travado conhecimento com parte não pequena do interior do Estado do Parít e do do Amazonas, visitando muitos logares travado conhecimento com parte não pequena do interior do Estado do Parál e do do Amazonas, visitando muitos logares
tambem repetidas vezes e em differentes estaçues do anno, tive largo ensejo fle constatar que as citadas descripçées saio verdadeiras, embora deram ser appliendas - felizmente! - so a algumas localidades. - No Estado do l'arí merece mençăo especial pela abundancia dos mosquitus toda a região costein do territorio do Aricary; na villa de Jontewegro (Amaná) por exemplo ein tempo de verño os mosquitos constituem um flagello insupuortavel, tanto peor que nas legiües destes insectos que infestam o referido logar é mui frequente a smorococr» (Anopheles), cuja vieaula é incomparavelmente mais dolorosa que a de todas as outras especies. Durante as grandes churas do inverno (e este é alli muito mais forte que em qualquer outra de todas as ontras especies. Durante as grandes chuvas do inverno (e este é alli muito mais forte que em qualquer untra cos exemplares, ao contrario já no fim de junho a demora na matta tornou-se um verdadeiro supplicio. Numa excursão que fiz naquelle tempu, seguindo a estrada que conduz da villa aos campos da terra firme (cerca 7 '/ kilometros) notei que a natta em toda a sua extensĩo era um verdadeirn viveiro de milhües de mosquitos. $\boldsymbol{A}$ sombra da matta estes perseguen a gente tanto de dia que á noite, nos loyrares expustos ao sol porem desalparecen durante as horas quentes; assim se explicu o facto que, quanlu ainda eu 1901 na citada villa os mosquitos eram insupportaveis mesmo de claro dia, no rerĩo do anno passak - depois dos graniles melhoramentos ali introduzidos pelo sr. Coronel Tavora, principalmente pela eliminação das capmeiras e das barracas decadentes que constituiram excelleutes escondrijos para os mosquitos -- sua appariçăo na villa limitara-se ás horas nocturnas. - To Aricary a zona infestada pelos mosquitos não se afasta muito dos Ciriulbaes e dos campos alagados; em Calçnene e na Ponta dos indios á embocadura do Oyapoc-lorgares onde o campo baixo fiea perto - ha ainda muitos, quando na regiảo das minas de Calçoene ou no posto fiscal do Oyapoc - logares situados na matta da terra-firme - o uso do mosquiteiro e perfeitamente dispensavel. Ds costa do Aricary a regiào da abumdanein de mos quitus acompanla a margem esquerda da embocadura do Amazonas; perto da cidade de Macapá e mais ainda nos rios da costa de Mazagão ( por exemplo no Anauerapacú) como na cidade de Mazagão mesmo a * moroçoca * no verão é frêquentissima. Ainda na regiào de Arrayollos, principalmente nos causpos baixos á raiz da serra dos castanhaes, os Anopheles săo terriveis.

Is ilhas da foz do Amazonas, embora muito pantanosas, sãn muito menos infestadas pela praga dos mosquitos do que os logares acima citados; no Anajis for exemplo (como aliás em todos os rios de agua preta) (quasi não se vé mosquitos.

Nas cidades e villas do baixo Amazonas ha muitos mosquites ao principio da estação secca, mas em p'rainha, Montealegre, Santarén e Obidos nunca pude encontrar a "mnroşoca *. São Taeniorhynelucs, P'tunoplites $e$ Culex, relativamente inoffensivos, que predominan ali. Jos cacoaes chega-se a ter o rosto e as nãos cobertas de Tueniorlmynchus, mas sem sentir por isso mas consequen tias. Differente e o caso $\mathrm{cm}$ Alenguer, logar aliás agradavel ả beira de bellissimos campos, mas onde no principio e muito mais ainda no fim do invemo os mosquitos são numerosissimos: nos camuos baixos

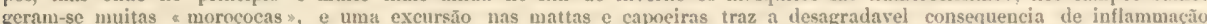
do rosto e das inãos. Ali vi a gente á bucca da noite fazer fumaça de esterco de gado para afugentar os mosquitos, mas É justamente a morogocas, que menos se incommoda com este processo. Entre villas e cidades neste Estado é a Alemquer que compete o segundo logar (depois do Amapá) na escala da frequencia dos mosquitos. - Nas aguas escuras do Trombetas nāo encontrei nuita praga. 0 mesmo da-se en Faro, porem lembro-me ter sido victima dos Anopheles n'uma excursão en que passei uma noite ao pé da Serra do côpa (Jamundá). Ẻu Santarún, Itaituba como provareelmente em todo o baixo T'apajoz ( rio de agua escura) os mosquitos são extremamente raros (menos a Stegomyia nas casas da cidade de Santarém); Anopheles nunca vi.

No interior do Estado do Amzonas é em geral mais o pium que incommoda a gente, do que os unosquitos, embora tambem estes sejam muito frequentes. O Anopheles encontra-se ali quasi em toda parte na matta geral, porem nunea em tamanha quantidade couno nos caupos alagados do baixo Amazonas e do Aricary. Um logar excepeionalmente infes. tado é Tabatinga; a matta geral tem poucus uosquitos e nenhum pium, mas o forte com seus etificios em ruinas e suas capoeiras nunea limpadas é um foco de pragas de primeira ordem. Nunca me esquecerei da quinzena alli passada, tanto 
Durante os ultimos annos me esforcei outrosim por organisar tabellas phaenologicas tendo por fim colligir elementos para julgar da frequencia numerica das diversas especies de Mosquitos em relação ás varias estações do anno, tomando por base de observação naturalmente o Museu e os seus arredores. Reconhecendo todavia que este material, que exige maior lapso de tempo, se acha em phase ainda por demais fragmentaria hoje, resolvi transferir a sua publicação para occasiao ulterior.

Eu tinha igualmente a principio nutrido o plano de accrescentar aqui ainda um capitulo especialmente dedicado á anatomia interna e a histologia comparadas das imagines e das larvas das nossas especies de Mosquitos paraenses as mais importantes, mormente de Stegomyia fasciata e de Culex fatigans. Dependendo porém a realisação de semelhante projecto sobretudo da faculdade de poder dispor de ampla liberdade de acção em materia de illustraçães, tenho de resignar por ora, todavia pronunciando a esperança, que me.seja ainda dado fazer d'este estudo assumpto de uma publicação especial no futuro.

PARA,

Fevereiro de 1904.

mais que para colleccionar insectos e plantas era obrigado a percorrer as capoeiras envez de permanecer a maior parte do dia debaixo do mosquiteiro. Yo forte mesmo os mosquitos são de dia tanto frequentes que á noite e alem d'elles ha de dia ainda nuvens de pium. Entretanto o logar não é pantanoso; parece envez que o estado decadente do forte é o principal factor de tamanha frequencia destes sanguinarios animaes. Felizmente parece não haver ali Inopheles.

Embora fora dos limites da Imazonia, quero ainda fallar sobre os Mlosquitos observados n'uma viagem nocturna no mangue do littoral do Maranhão, da fazenda Piry-mirim á Alcantara. Eimbora alli nào houvesse agua dóce, fomos assaltados por verdadeiros enxames de mosquitos, os quaes indubitavelmente se geriram nos pautanos de agua salobra.

Belém do Parí, 13-Março de 1905. 


\title{
Stegomyia fasciata, o mosquito transmissor da febre amarella, e o actual estado de conhecimentos sobre a causa da mesma molestia.
}

\author{
(Conferencia realisada perante o Congresso Internacional \\ de Zoologia em Berna (Suissa), agosto, 1904). ( ${ }^{*}$ )
}

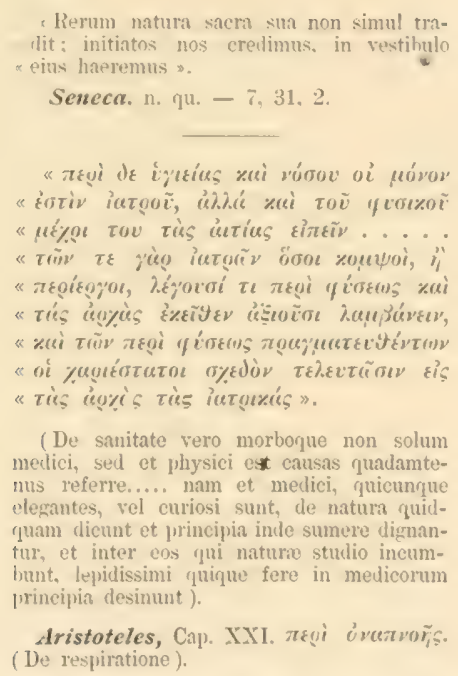

1). Colleccionamento methodico que já dura alguns annos, dos numerosos $\mathrm{Cu}$ licides ou mosquitos haematophagos da região amazonica, ensina-nos que devemos considerar como principalmente molestando o homem e portanto merecedores de attenção do ponto de vista sanitario, as especies: 1) Anopheles argyrotarsis e a variedade, muitas vezes encontrada simultaneamente e nas mesmas localidades, Anoph. argyrotarsis albipes (Theobald). 2) Mansonia (Panoplites) titillans e M. amazonica. 3) Taeniorhynchus fasciolatus. 4) Ianthinosoma Lutzii. 5) Culex confirmatus. 6) Melanoconion atratum. 7 ) Stegomyia fasciata. 8) Culex fatigans.

2). As 6 especies enumeradas em primeira linha, ao lado de algumas outras, ás quaes sómente assiste um papel mais secundario, perseguem o homem, umas mais durante o dia, outras mais durante a noite, mormente ao ar livre: na mata, no campo, no cipoal e no brejo, ao passo que as duas ultimas, Stegomyia fasciata e Culex fatigans

(*) Vertido pela primeira vez do original allemão para o portuguez. 
tornaram-se flagellos domesticos propriamente ditos, molestando sobretudo o morador das cidades. A sua vida, com todo o seu cyclo evolutivo, se desenrola dentro e ao redor das habitações humanas. No mais a Stegomyia fasciata é um animal predominantemente diurno, com pronunciadas inclinações photophilas, ao passo que o Culex fatigans deve ser chamado da mesma fórma um insecto nocturno. A actividade de ambos se substitue, reveza e completa actualmente na cidade do Pará em regular cyclo diario.

3). Ao laclo das especies que se tornam penosas pela sua indole sanguinaria e a sua impertinencia, pelo seu numero e a dôr physica produzida no momento da picada, e que se deixam rubricar em hierarchia especial, uma importancia sanitaria indeclinavel đesde já se percebe nitidamente nas seguintes 3 especies: 1) Anopheles argyrotarsis - em relação á Malaria, 2) Stegomyia fasciata -- em relação á Febre amarella e 3) Culex fatigans - em relação á Filariase.

4). O Anopheles entra menos em conta para a cidade do Pará, do que para as zonas baixas e paludosas no interior do Estado, para o sertão. Attento a que o Anopheles, conforme observações pessoaes nossas, raras vezes, ou só esporadicamente se apresenta na cidade e sua peripheria (cerca de $8-12$ exemplares durante os ultimos 2 a 3 annos) creio poder predizer positivamente que dos diversos casos de molestias febris, as quaes são reunidas pela medicina indigena debaixo da noção collectiva "impaludismo", a maioria vae ser reconhecida como jazendo fóra da concepção "malaria", quando submettida ao microscopio e á investigação methodica do sangue. O que se encontrar por ahi de "malaria " genuina e propriamente dita, terá sido adquirido por via de regra no interior do paiz e trazido de fóra.

5). Não tendo sido cabalmente investigado até agora em especie alguma de Culicideo do Novo ou do Velho munảo o problema da alimentação na sua interferencia na duração da vida e na fertilidade das femeas, nem tão pouco o problema da copula na sua reacção sobre a haemaphilia das femeas, iniciou-se no Pará durante o anno de 1903, com Stegomyia fasciata e Culex fatigans, uma longa serie de experiencias, pela qual ficaram definitivamente investigadas estas relações pelo methodo experimental e conforme um plano methodico e um questionario minucioso, servindo-se de cerca de 220 individuos adultos de uma especie e approximativamente 260 individuos da outra especie.

6). Entre os resultados dessa investigação, que fórma o assumpto de uma memoria circumstanciada, publicada no idioma portuguez, faz alguns mezes, chamo a attenção especial para os seguintes: 
a) mel e succo assucarado formam, para o individuo feminino da imago de ambas as especies mencionadas de mosquitos, uma alimentação vantajosa no sentido de prolongar a duração da vida; outro porém será o julgamento, tendo-se em vista o interesse da conservação da especie, pois este modo de alimentação exerce visivelmente uma influencia retardativa sobre o processo da reproducção, isto é, sobre a postura dos ovos. Mediante exclusiva alimentação com mel foi possivel reter a postura dos ovos até além de 100 dias, para deixal-a subitamente realisar-se pela interpolação de alimento sanguineo;

b) a sucção do sangue tornou-se para as femeas das mencionadas especies de mosquitos um postulado necessario e indispensavel para a postura de ovos capazes de se desenvolver. Eu digo expressamente: . . . . « tornou-se" porque diversas razões levam-me a suppôr que temos ahi uma innovação de adaptação relativamente moderna, cujas vantagens poderiam ser encontradas por um lado na maturação accelerada dos ovos ovariaes, por outro lado porém principalmente n'um accrescimo quantitativo dos proprios ovos;

c) Já com uma unica ração de sangue torna-se sensivel o effeito favoravel para a postura, tendo comtudo esta por effeito sómente uma soltura parcial e fraccionada dos ovos. Um esgotamento propriamente dito da provisão de ovos só succede depois de duas a trez rações de sangue em intervallos parallelos á rapidez da digestão.

d) Digno de nota é que tambem imagines femininas não fecundadas podem proceder á postura de ovos depois de alimentação sanguinea. Os ovos assim fornecidos todavia provaram em todos os casos serem inaptos a se desenvolver; designo-os como pseudo-parthenogeneticos.

e) Assim se acha portanto demonstrado por processo experimental, pelo menos em relação ás duas especies de Culicides precitadas, uma relação de dependencia entre a postura normal dos ovos e o chupar sangue n'um vertebrado superior - relação de dependencia que deverá ser reconhecida como phase de transição para o parasitismo definitivo. Será assumpto de investigação especial examinar se esta relação de dependencia poderá ser constatada, e até que grao, tambem em outras especies de mosquitos que molestam, pela sucção de sangue, o homem e os vertebrados superiores.

f) Na Stegomyia fasciata não póde pairar duvida alguma, que tambem os machos se tornam incommodativos ao homem sorvendo gottasinhas de suor na superficie do corpo. Para uma perfuração effectiva da epiderme, porém, a sua tromba é demasiado fraca. Ora, as femeas, n'este sentido melhor apparelhadas, não se contentaram com o chupar de suor e de serum e passaram a perfurar habitualmente e avançar em demanda directa ao sangue dos animaes-hospedes. E', d'est'arte, bellissimamente demonstrada n'esta especie o caminho historico e o percurso evolutivo percorrido pela haemaphilia. E' digno de attenção outrosim, do ponto de vista sanitario, que ao longo do littoral do Brazil a impertinencia da Stegomyia nas imagines de ambos os sexos se comporta visivelmente proporcional á altura da temperatura, respectivamente á intensidade da transpiração.

7). Ao contrario da opinião até agora assaz divulgada, que suppõe a patria da Stegomyia fasciata ser a região antilhana, ligando o seu primeiro apparecimento com 
a viagem da descoberta de Colombo, eu não hesito, por diversas razões que resultam em primeira linha de um exame critico da actual distribuição geographica do genero inteiro Stegomyia, em estabelecer esta outra de que a patria, proveniencia e centro de dispersão d'esta perigosa especie de mosquito deve ser procurada na Africa. A sua disseminação sobre a costa neotropica atlantica explico-me (tal como em não poucos outros transmissores que hoje no Brazil se costumam attribuir ao inventario apparentemente indigena de molestias) pelo trafico de escraros em tempos passados.

8). No que diz respeito a phase actual da questão da febre amarella, a supposição hoje já universalmente acceita, e baseada em experiencias realisadas em Cuba pelos medicos norte-americanos Reed, Caroll e Agramonte - a saber que esta molestia deve a sua origem á picada da especie de Culicides Stegomyia fasciata, achou agora todo recentemente tambem no Brazil e na Sul-America inteira applauso geral, tanto que na imprensa d'estes paizes interpretações discrepantes e duvidas sómente isoladas se arriscam. O sentimento da certeza n'esta conclusão encontra no Brazil o seu reforço principal pelos ensaios de repetição da experiencia cubana da transmissão artificial por uma commissão medica no Estado de S. Paulo, por um lado, e por outro lado pela commissio medica (Drs. Marchoux, Salimbeni e Simon), enviada pelo Instituto Pasteur de Paris ao Rio de Janeiro com o fim de estudar a febre amarella.

9). No seu "Rapport", publicado em novembro de 1903 nos "Annales de l'Institut Pasteur", sobre os resultados dos seus estudos, a mencionada commissão estabelece outrosim ainda os seguintes resultados, conclusũes e conjecturas:

a) Para provocar febre amarella, o mosquito deve primeiramente ter-se infeccionado, chupando sangue de um doente amarillico durante os trez primeiros dias do curso da molestia (pag. 729, Conclusion 17) e o serum do doente do terceiro dia é virulento (pag. 728, Conclusion 1).

b) A Stegomyia infeccionada é perigosa sómente depois de um intervallo de 12 dias desde a resorpção de sangue virulento (Conclusion 18) e o seu perigo augmenta na proporção da differença do tempo que decorre entre a auto-infecção e a re-picada (Conclusion 20).

c) A picada de duas Stegomyias infeccionadas póde dar origem a um caso grave de febre amarella (Conclusion 19). Mas a picada de mosquitos infeccionados não causa infallivelmente a febre amarella ("ne donne pas fatalement la fièvre jaune") (Conclusion 21).

d) A opinião popular de que a infecção da febre amarella se effectua de noite, explicar-se-ia pela circumstancia da femea de Stegomyia, depois de ter chupado sangue pela primeira vez, inverter a sua vida até então diurna, para tornar-se d'ahi em diante um insecto nocturno (pag. 693). Por uma conclusão complementar necessaria resultaria d'ahi que as femeas de Stegomyias infeccionantes deveriam ser procuradas e encontradas unica e exclusivamente entre os individuos que picam de noite. 
e) tambem a copula se realisa de noite e na escuridão, sendo raras vezes e difficilmente observada (pag. 681) e, em geral, as mais importantes funcções vitaes d'esta especie se realisam sob a protecção da escuridão nocturna ( c'est surtout à la faveur de l'obscurité et pendant la nuit que s'accomplissent les fonctions les plus importantes de l'existence de l'espèce» (pag. 686).

f) Embora se confesse que a missão findou negativamente n'este sentido, que outra vez nem no mosquito proprio, nem no sangue poude ser demonstrado o "agens» da febre amarella ("nous n'arons réussi jusqu'á présent de mettre en evidence l'agent de la fièvre jaune») (pag. 730, Conclus. 30), todavia pela marcha toda da investigação, do questionario e da argumentação resalta com nitidez impossirel de desconhecer, que a existencia e a actividade de um parasita do sangue, ( - como causador organisado e animal de molestia, com marcha evolutiva temporariamente determinada e duração dada da incubação, ligado á transmissão por certos individuos femininos de Stegomyia infeccionados -) formou a supposição, opinião e ponto de partida, pendentes no ar -, digamos em summa, suppoz-se uma relação de analogia exactamente congruente entre Stegomyia e Febre amarella, como ella de facto existe entre Anopheles e Mialaria pelo intermedio do "Plasmodium malariae" e entre Culex fatigans e Filariase pelo intermedio da Filaria sanguinis hominis.

10). Conscienciosos estudos originaes sobre os pormenores do modo de rida da Stegomyia fasciata por um lado; a occasião pessoal de observação exacta e de accompanhamento desde o primeiro principio até o exito infelizmente letal de um caso typico de febre amarella por outro lado; outrosim o aprofundar a literatura medica a mais recente (1) bem como a anterior sobre a febre amarella e finalmente o raciocinio critico e o exame do que cheguei a vêr pessoalmente durante 20 annos n'um meio considerado mais ou menos como classico a respeito da febre amarella e a ouvir de fonte merecedora de fé, - tudo isto levou-me á inabalavel convicção de que exactamente em algumas d'aquellas questões biologicas concernentes ao modo de vída da Stegomyia, que são de alcance na presente discussão como pontos essenciaes e cardeaes, a verdade é diversa do que poderia parecer pela exposição da commissão medica franceza. E tal qual como divergem os meus proprios resultados biologicos relativos a mosquito da febre amarella, também em relação á etiologia da febre amarella rejo-me impellido para uma concepção diversa, que tentarei precisar em termos breves:

11). Em primeira linha direi que eu tambem me confesso adepto do conhecimento de que é na Stegomyia fasciata que temos de procurar o transmissor e disseminador da febre amarella;

(1) Nesta occasiaio nảo posso deixar de frisar, que o sutstancioso e excellente "Report of the Yellow FeverExpedition to Pará 1900 \% editado pela \& School of Tropical Medicine em Liverpool (1902) e redigido pelos medicos inglezes Drs. Durham e Iyers (dos quaes o ultimo succumbiu como victima do seu zelo profissional) me foi de valor dc todo especial pela sua exposiçào sobria e objectiva. 
12). Ao contrario porém da moderna corrente de opinixo, que o "agens " da febre amarella deve ser reconhecido n'um parasita organisado do sangue em analogia com a relação entre Anopheles e Malaria (Plasmodium malariae), sinto-me impellido á supposição de que uma tal analogia, que quadrasse total e completamente, não existe e que o "agens" deve ser antes supposto na fórma de um veneno organico, n'uma toxina, que em primeira instancia normalmente possue a sua séde e ponto de partida nas glanclulas salivares de Stegomyia fasciata e é inoculado ao homem mediante a picada. (1)

13). Cada picada isolada é venenosa em geral e como transmissor normal age e serve por si só cada individuo feminino de Stegomyia no momento da picada. Cada picada é uma infecção parcial; a infecção total é alcançada pelo effeito sommado de todas as picadas isoladas, isto é, de todas as infecções parciaes.

14). O reneno inherente ás glandulas salivares da Stegomyia é fretado pelo sangue da peripheria para as partes internas e o figado, seja na luta contra este (o que julgo mais provavel), seja como alliado d'elle (podendo talvez transformar por sua vez em toxinas novas, venenosas ) fica incitado a uma actividade anormal, que acha a sua expressão interna e externa n'um icterus de alto grau. (Conforme o julgamento uniforme, no exame cadaverico, o figado intensamente amarello, gordurosamente degenerado, é tão regularmente o primeiro phenomeno, que prende a attenção, como o amarellar mais ou menos extensivo da epiderme costuma contar entre os signaes nosologicos constantes em certa phase da molestia - , tanto que, com toda a razão, foi até aproveitado para a propria nomenclatura da molestia.

15). Se nas descripções de envenenamentos occasionados pela mordedura de outros animaes venenosos, portanto pelo secreto das suas glandulas salivares, se elimi-

(1) Para defini e circumscrever de modo mais exacto a minha opiniāo e maneira de vèr em opposição ás tendencias actualmente em moda nos circulos medicos, eu desejava aqui frizar e archivar uma vez por todas, que eu menos me opponbo a acceitaçio de $\mathrm{m}$ parasila do sangue em geral, do que d de um parasita do sangue relativamente lão grande e preporcionalmente bem desentolvido, como nos casos da Malaria e da Filiariase.

A prudencia ainda aconselha a reservar espaço para a possibilidade de no fim das contas eventualmente uma d'aquellas diminutissimas fórmas de bacterias poder entrar em acçấo, e que. se nảo podem ser vistas directamente como individuos isolados pelos nossos actuaes meios de reconhecimento opticos e outros, comtudo em massas compactas podem assumir fórma e feição accessiveis á percepçâo pelo sensorio.

Semelhante possibilidade transparece também por não poucos trechos do valioso relatorio da commissĩo medica ingleza (Dr. Durham e Irr. Myers) relativamente aos seus estudos realisados no Pará. Logo n'uma dos primeiras paginas encontra-se a phrase: "That a yellow fever microbe exists there can be no question *. (pag. 3 ). Falla-se lá de certa especie de bacteria, que por um lado foi encontrada nos diversos orgãos de doentes amarillicos, por outro lado no proprio mosquito Sterromyia e parece que a regularidade do seu encontro nào falhou de produzir impressão no animo dos mencionados autores.

Se, por um lado, pela concessão de tal possibilidade o ponto de vista rigorosamente theorico se desloca de alguma fórma, eu, pelo outro lado, o lado pratico, nāo consigo entrever uma deslocação muito essencial da situacão. Todas as questỏes, por exemplo, attinentes ao terreno da prophylaxia e da defensiva, não seriam affectadas pelo veredictum, qualquer que seja o seu theor. Também o que ha de especifico na minha supposição sobre o modo da transmissáo e da disseminação da febre amarella não viria a soffrer a menor modificaçăo, quer como causa final resultasse uma toxina organica ou uma fórma de bacteria infinitamente pequena. 
nam os phenomenos locaes (os quaes, proporcionalmente ao tamanho da ferida e á quantidade do veneno injectado, naturalmente predominam, as vezes), a facies nosologica restante e fornecida pelos phenomenos geraes ganha uma certa semelhança difficil de desconhecer, com a febre amarella (Confer symptomatologia da mordedura de cobra (ophidismo) em Scheube "Krankheiten der warmen Länder " 1903 (pag. 450-461) pag. 453, Especialmente o icterus parece apresentar-se como phenomeno usual de acompanhamento, o que, ao ler da respectiva litteratura medica (vide por exemplo Scheube, loc. cit. 3. Aufl. 1903, pag. $461 \mathrm{seg.),} \mathrm{não} \mathrm{deixou} \mathrm{de} \mathrm{impressionar-me} \mathrm{de} \mathrm{modo} \mathrm{todo} \mathrm{duravel.}$ Que se compare o que lá se refere em relação á symptomatologia da mordedura de escorpiões (pag. 463-464), de certas aranhas (por exemplo Latrodectes mactans) pag. 465, e de carrapatos (Ixodideos) (pag. 465-466).

16). Mas tambem outros envenenamentos com materias organicas e anorganicas fornecem um quadro nosologico no qual o icterus e a destruição haemolytica se apresenta de um modo imponente no primeiro plano; basta, por exemplo, lembrar os envenenamentos com phosphoro.

17). A erupção da febre-amarella n'um recem-chegado - o qual, se de um aspecto florescente, cheio de sangue e fortemente transpirando, possuirá particular força de attracção para a Stegomyia - parece em geral effectuar-se de modo que depois de precedida por uma infecção total de Stegomyia, que poderá extender-se sobre semanas e mezes, o escapamento se realisa mediante um embaraço gastrico (catarrho intestinal, resfriamento, etc.). A situação é assaz bem comparavel á de uma arma de fogo carregada e armada, onde a detonação se faz em consequencia de um pequeno trabalho mechanico no gatilho: se este não se realisar, tambem a detonação ficara sem se fazer : a arma, carregada e aperrada, poderá enferrujar - é a immunisação natural.

18). O embaraço gastrico affectará em ultima instancia as funcções do figado e assim a toxina, fornecida pela intoxição mediante a Stegomyia e armazenada, poderia ser instigada á virulencia e auxiliada em seu effeito destruidor.

19). Deve-se portanto distinguir entre intoxicação e phenomeno de acompanhamento. A primeira se effectuará de dia, ao passo que o ultimo será apanhado, por via de regra, de noite. Assim se resolve o problema dos assim chamados "Diarios de Petropolis» (precisa sómente juntar-se ainda a supposição, já em si provavel, que contra a intoxicação adquirida de dia nos quarteirões commerciaes da cidade do Rio de Janeiro, age regularmente e com successo a formação de uma anti-toxina favorecida pelas mudanças climatericas), problema que tanto quebrar de cabeças causou e em favor do qual "pour le besoin de la cause" a commissão franceza no Rio de Janeiro violentou os factos, fazendo da femea de Stegomyia um animal nocturno. Mas o que se adquire 
de noite, não será tanto a infecção da propria febre amarella, como a materia inflammavel para a explosão e a occasião para o escapamento da catastrophe. Assim o compromisso entre o empirismo popular e a realidade dos factos fica, por um meio simples, removido para o foco de uma claridade comprehensivel.

A relação mutua entre intoxicação e antitoxina, como ella se me afigura, poderia ser com vantagem comparada com uma conta-corrente, onde no Deve e no Haver lançamentos diarios são escripturados, guardando entre si quasi o equilibrio: effeitos sommados em relação á quantidade e á duração de tempo, em ambos os lados. Um pequeno saldo diario a favor da antitoxina approxima, para aquelle que reside continuadamente n'um ambiente de febre amarella, a chegada da immunisação; a relação inversa porém se inicia, por exemplo, por um embaraço gastrico, repetindo-se caso e effeito da gotta d'agua, pela qual o copo repleto é levado a transbordar. Que o deficit efficiente quer de um lado, quer do outro, não precisa ser lá muito consideravel, é demonstrado nitidamente pelo facto de que nos taes "Diarios de Petropolis "jámais se estabelece uma effectiva immunisação.

20). Pelas considerações antecedentes não tenciono absolutamente negar a possibilidade da infecção de uma pessoa san por um doente amarillico pela transmissão directa mediante a picada de Stegomyia. Pelo contrario, a minha propria opinião da natu. reza e do modo de originar-se a febre amarella carece d'esta possibilidade e supponho mesmo que a uma tal toxina assiste uma virulencia augmentada e um effeito potenciado. Ligo com este modo directo de transmissão os casos com duração minima de desenvolvimento e as epidemias propriamente ditas, alastrando cyclicamente, ao passo que explico pelo caminho lento da intoxicação fraccionada mediante os effeitos reunidos das picadas isoladas, a genese abrupta e salteada de focos da molestia de todo novos, supposto naturalmente: 1) que a Stegomyia exista na respectiva localidade; 2 ) que lá sejam dadas as condições de existencia climatericas necessarias para e sua reproducção desembaraçada.

21). Na marcha nosologica da febre amarella distinguem-se: primeiro, um estagio inflammatorio-congestivo; depois, um estado de remissões, que se delimita contra o outro pela queda da temperatura. Ora, constitue uma conhecida particularidade d'esta molestia, que a entrada da mencionada remissão não observa regra certa alguma de tempo, podendo tanto apresentar-se depois de 2 a 3 dias, como depois de decorrido o dobro d'esse tempo. N'esta irregularidade caprichosa reside, ao nosso vêr, mais um valioso argumento para a supposição de uma toxina, porque no caso de existir um parasita do sangue em estricta analogia á Malaria, deveriamos esperar que a sua existencia achasse a sua expressão externamente visivel e perceptivel por uma periodicidade temporaria, mais ou menos nitidamente pronunciada, e por um periodo incubatorio submisso á regra e á lei. 
22). Deveria ser possivel, por um trabalho cuidadoso e paciente preparar a en masse " de thoraces frescos de Stegomyia, onde se acham local sados no quadrante anteroinferior as glandulas salivares, a secreção d'estas glandulas salivares em estado de reacção plenar e em quantidades taes que fossem sufficientes pari permittir experiencias directas physiologicas e therapeuticas e fizessem mais nitido o processo de intoxicação, em escala augmentada. Taes ensaios seriam de um interesse de todo especial em dupla direcção: 1) em relação á questão do comportamento do sangue ao encontrar-se com a secreção das glandulas salivares da Stegomyia; 2) em relação ao comportamento do figado no caso da injecção directa com a dita secreção.

23). Um dos principaes periodicos de medicina do Brazil, o "Brazil-Mledico", hebdomadario publicado no Rio de Janeiro, traz n'um dos ultimos numeros que me veio ás mãos ainda pouco antes do meu embarque para cí, um artigo com a noticia de recentes ensaios curativos, accompanhados de successo, em doentes amarillicos mediante injecção de "serum anti-crotalico" e de "serum anti-bothropico", portanto mediante inoculação de serum curativo obtido e attenuado de veneno ophidico e dirigido contra a mordedura e a peçonha ophidica. Também os homeopathas os mais affamados do Brazil apontam com orgulho para os resultados favoraveis que dizem ter alcançado de ha annos e em tempos de epidemias intensas, na luta contra a febre amarella pelo seu especifico denominado "crotalus * e preparado com a secreção da glandula salivar venenifera da cascavel. Poderá pensar-se a este respeito como se quizer, não se consegue libertar-se n'esta. emergencia da divisa "Similia similibus" e se no campo tanto dos allopathas como dos homeopathas se aponta para a applicação de taes substancias medicamentosas manipuladas com veneno ophidico, por emquanto como resultado de reconhecimento meramente empirico, serí permittido constatar que a theoria hoje em dia já está preparada para apresentar a respectiva explicação, e que a minha supposição da febre amarella como uma intoxicação pela secreção das glandulas saliva. res da Stegomyia recebe, d'este lado empirico, significativa alliança.

24). Se a minha theoria, achada mediante meios de todo independentes, vier a receber, como estou convencido, pela sciencia medica, em tempo não muito remoto a sua confirmação nos seus pontos essenciaes, vejo, qual astro clemente, luzir por cima da humanidade soffredora a fundada esperança de que a fragil embarcação em busca de prophylaxia e defensiva efficazes estribadas em principios scientificos inderrocaveis, abandonando o dominio das ondas no mar largo do accaso, ache o verdadeiro canal e entre no porto seguro do saber positivo.

25). Do ponto de vista prophylactico ficará de pé, como regra fundamental, depois como d'antes: "O ultimo caso de febre amarella coincidirá com a ultima femea de Stegomyia. Exterminae este transmissor dentro e ao redor das cidades, e esta mo- 
lestia se extinguirá por si mesma ». A febre amarella sómente -não se extinguirá n'aquellas cidades, onde e emquanto não se quer! - Pleno applauso merece o procedimento radical, baseado n'esta orientação scientifica, que, applicado recentemente por parte do chefe do serviço sanitario federal do Brazil. Dr. Oswaldo Cruz, em relação á cidade do Rio de Janeiro, com brilhante successo, seguinclo o exemplo e o preceito das "mosquito-brigadas" postas em scena pelo benemerito medico e hygienista inglez, Ronald Ross.

Original allemão redigido a bordo do vapor * Argentina *, durante a travessia do Brazil a Europa, em julho de 1904 . 


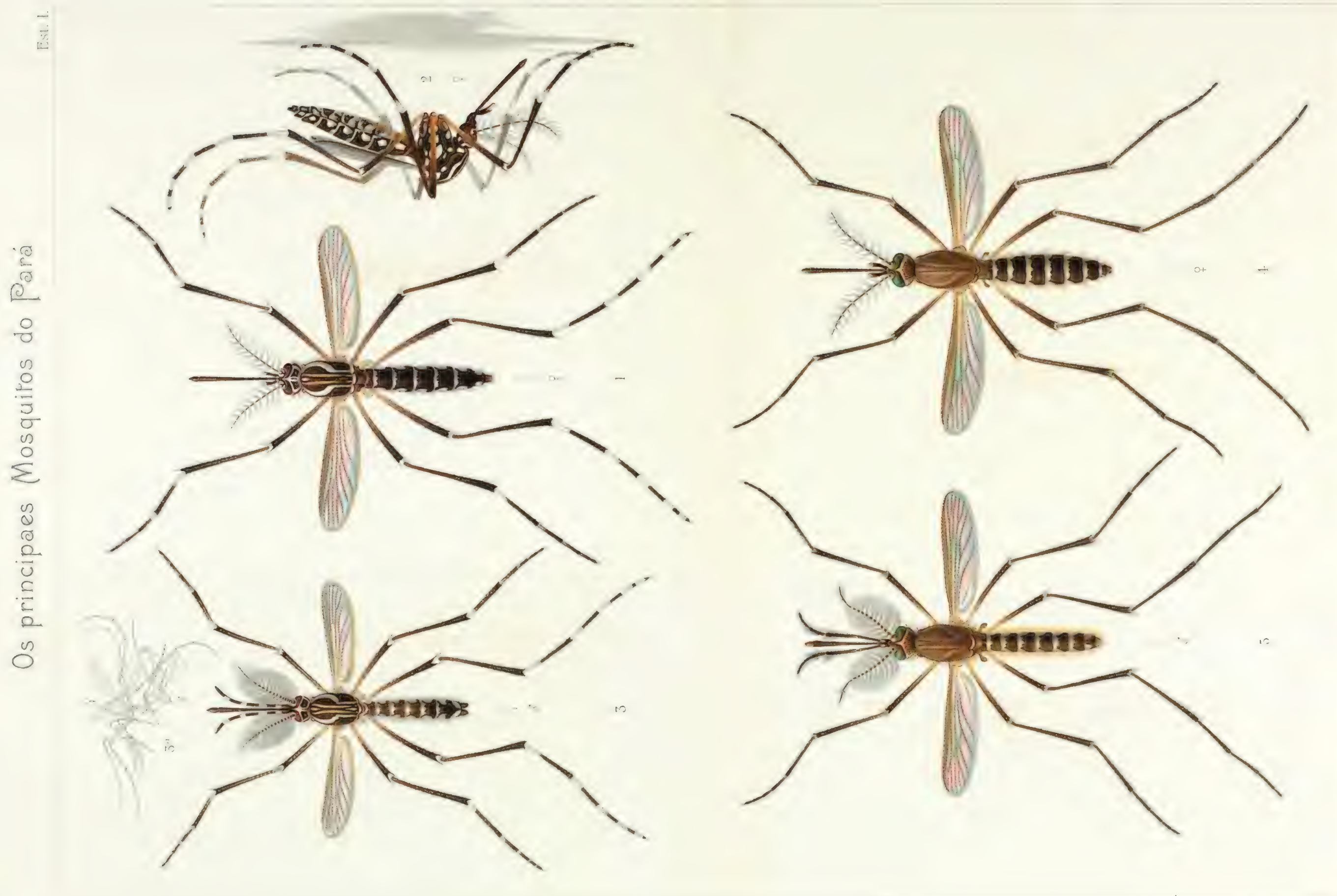




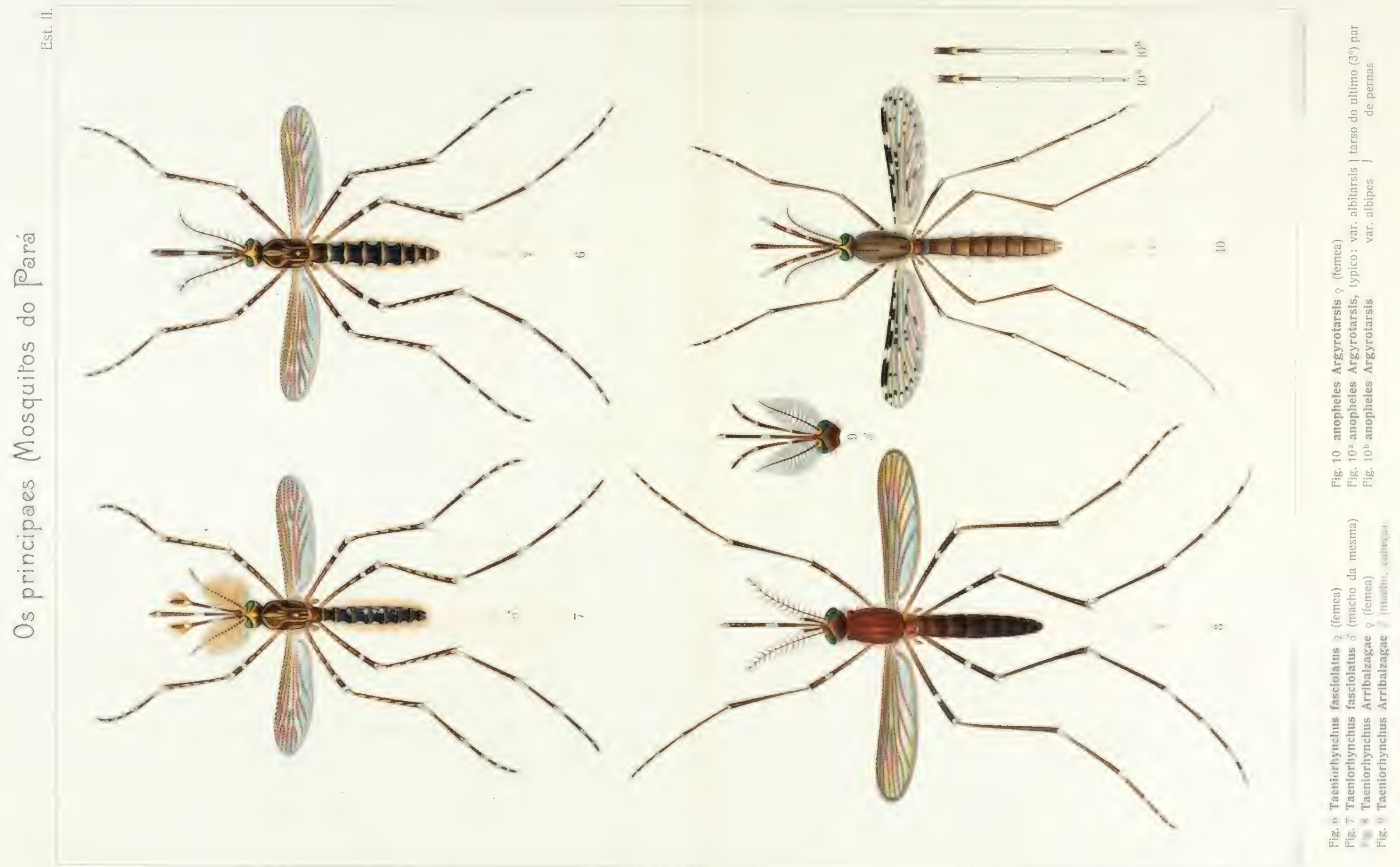



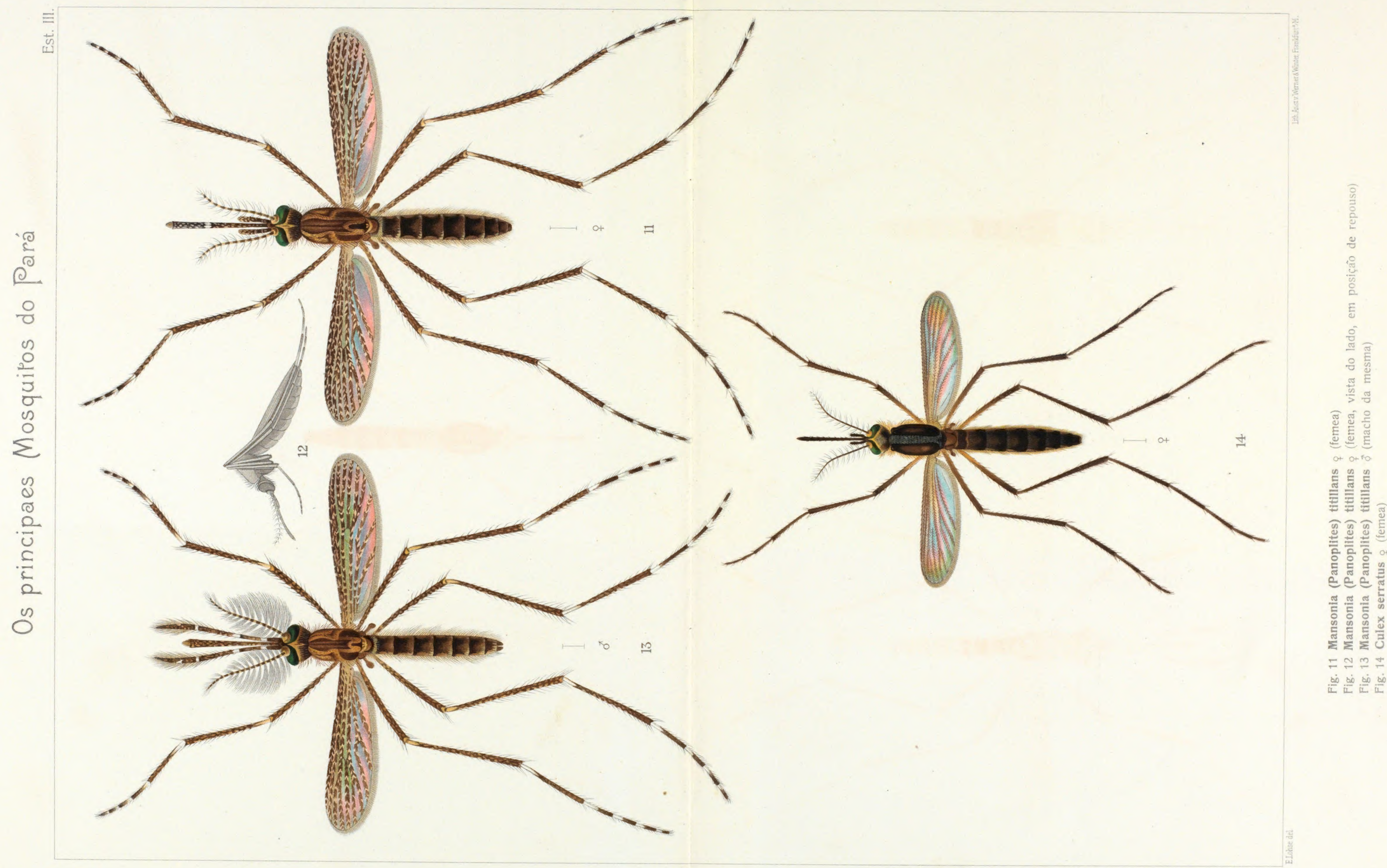


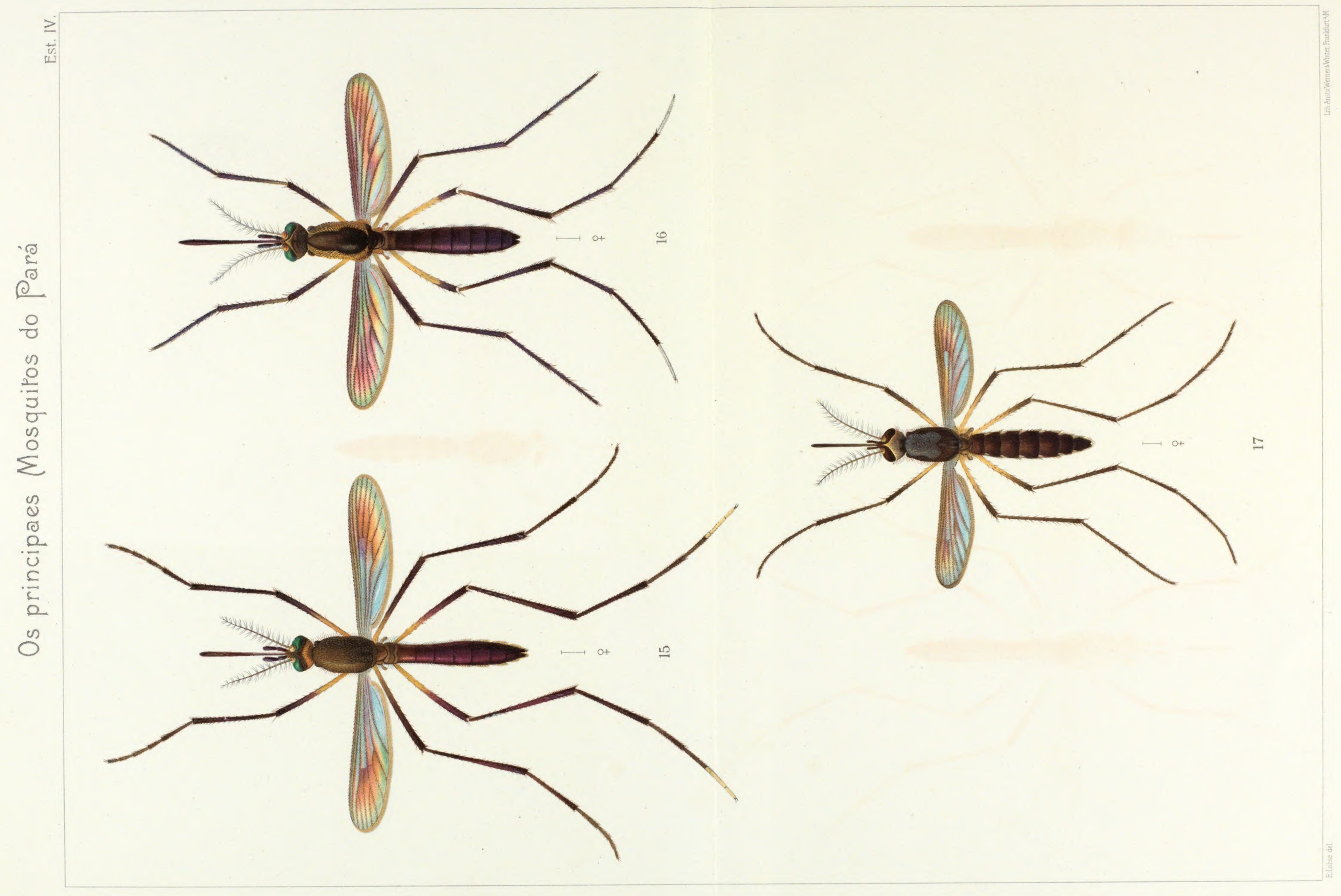



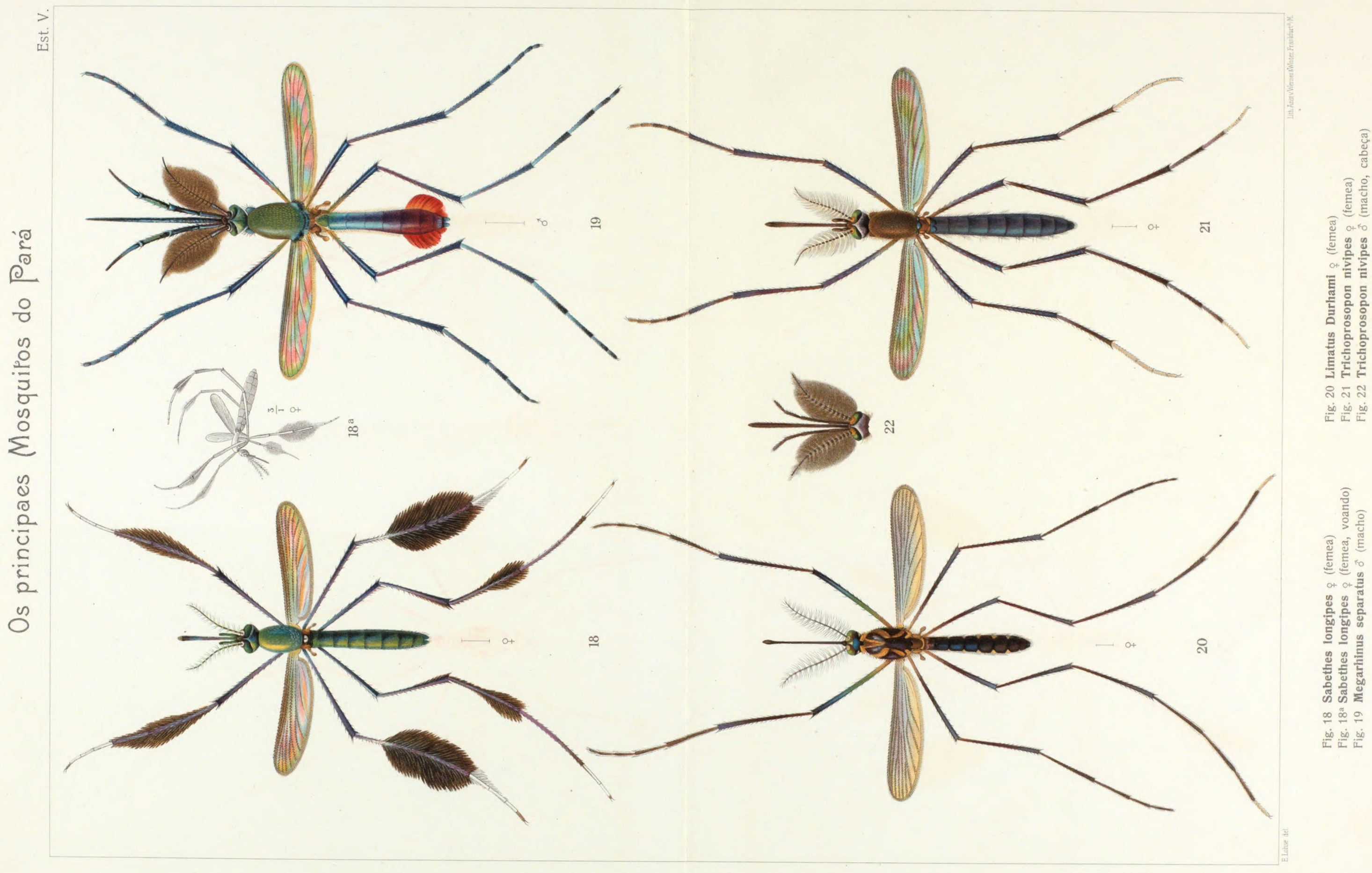
. 